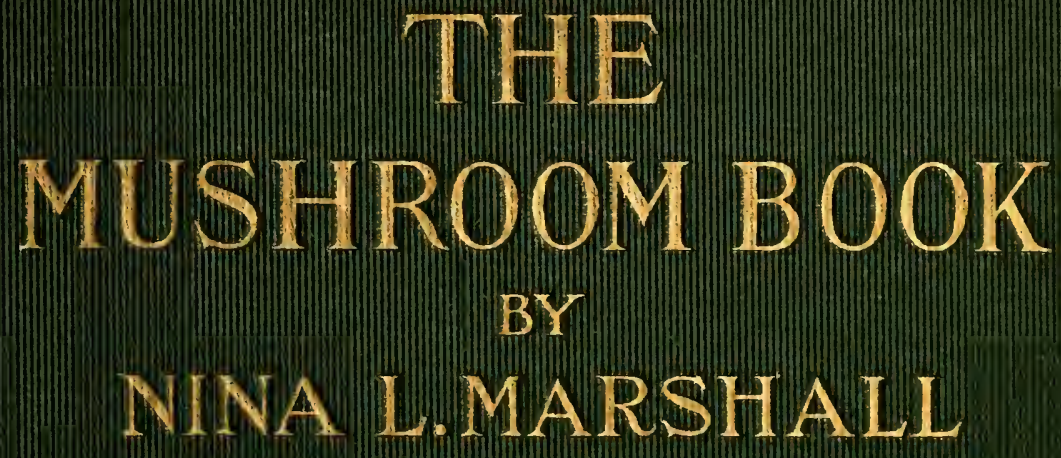




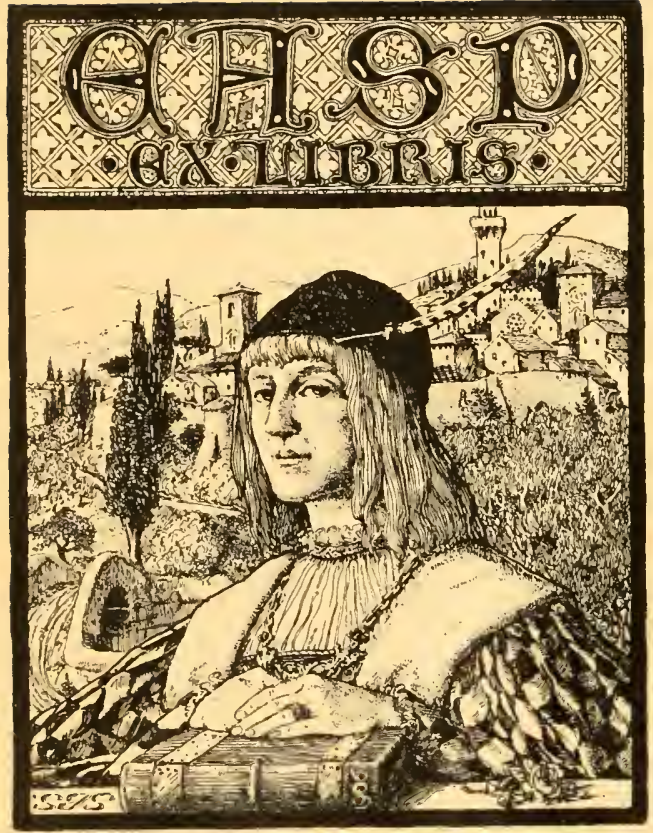

THE LUESTHER T. MERTZ LIERARY

THE NEW YORK BOTANICAL GARDEN 


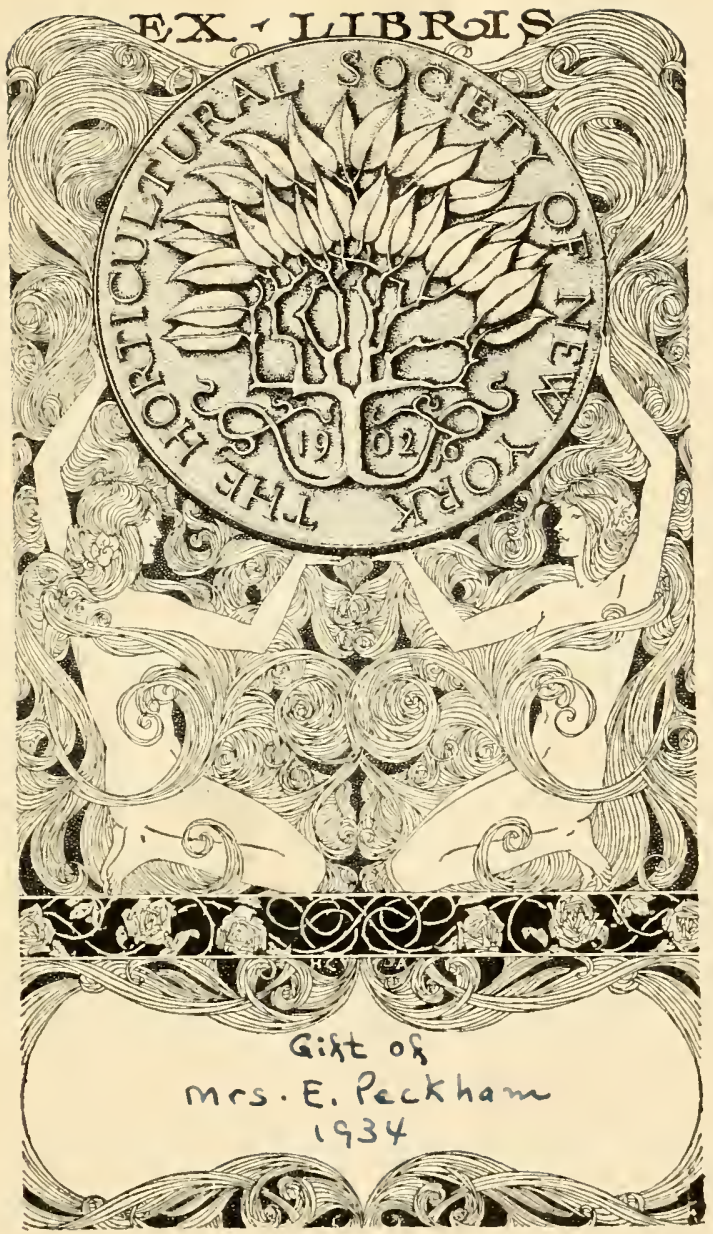



THE MUSHROOM BOOK 




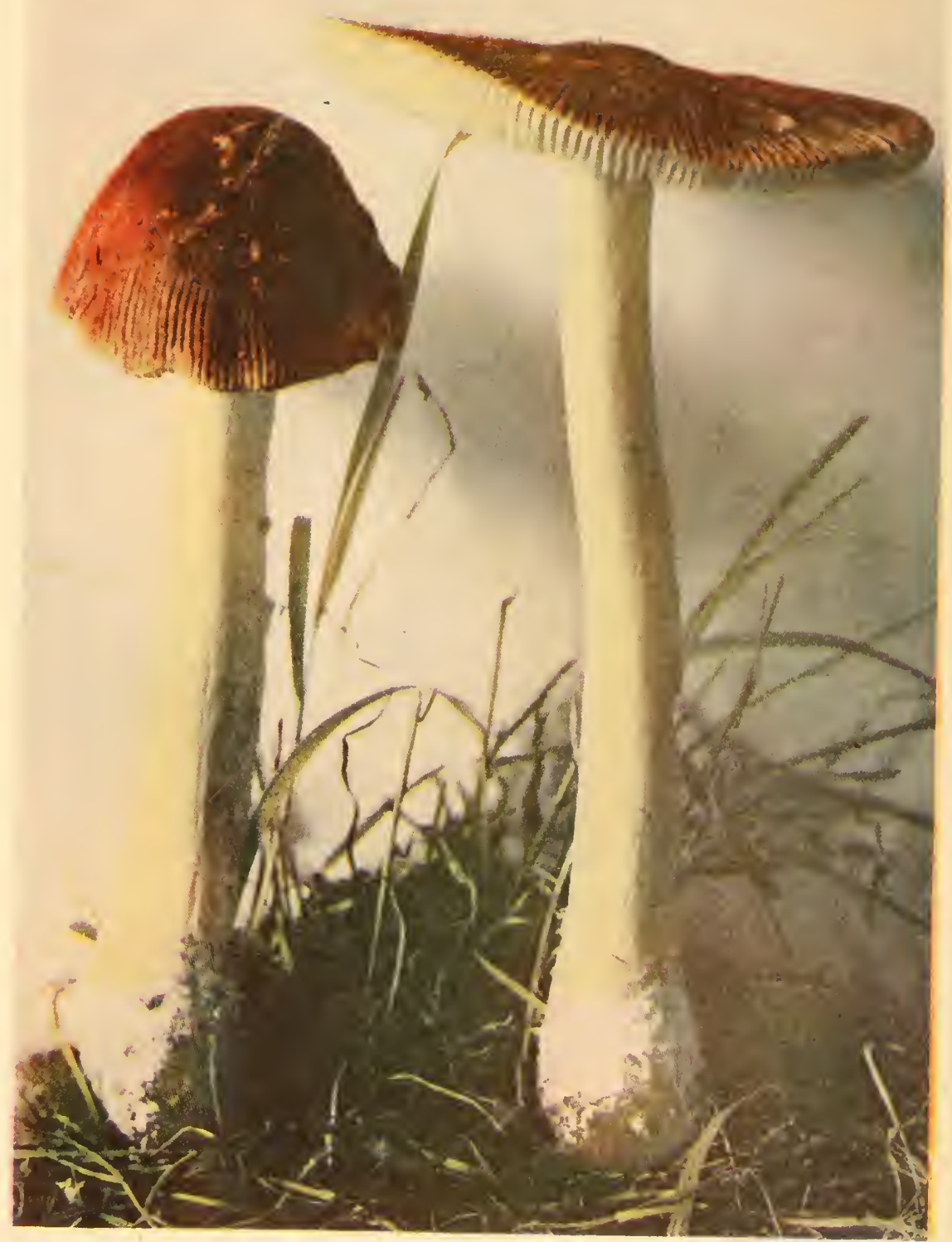

Amanitopsis parcivolvata, Pk. See page 55. 


\title{
THE MUSHROOM \\ B OOK. a popular guide to THE IDENTIFICATION AND STUDY OF OUR COMMONER FUNGI, WITH SPECIAL EMPHASIS ON THE EDIBLE VARIETIES
}

\author{
BY \\ NINA L. MARSHALL
}

WITH MANY ILLUSTRATIONS IN COLOR AND BLACK AND WHITE PHOTOGRAPHED HROM NATURE BY J. A. \& H. C. ANDERSON

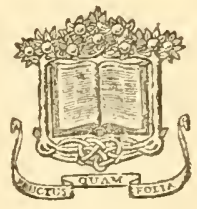

Garden City New York DOUBLEDAY, PAGE \& COMPANY 1920 
Copyright, 1901, 1904, by Doubleday, Page \& Company 


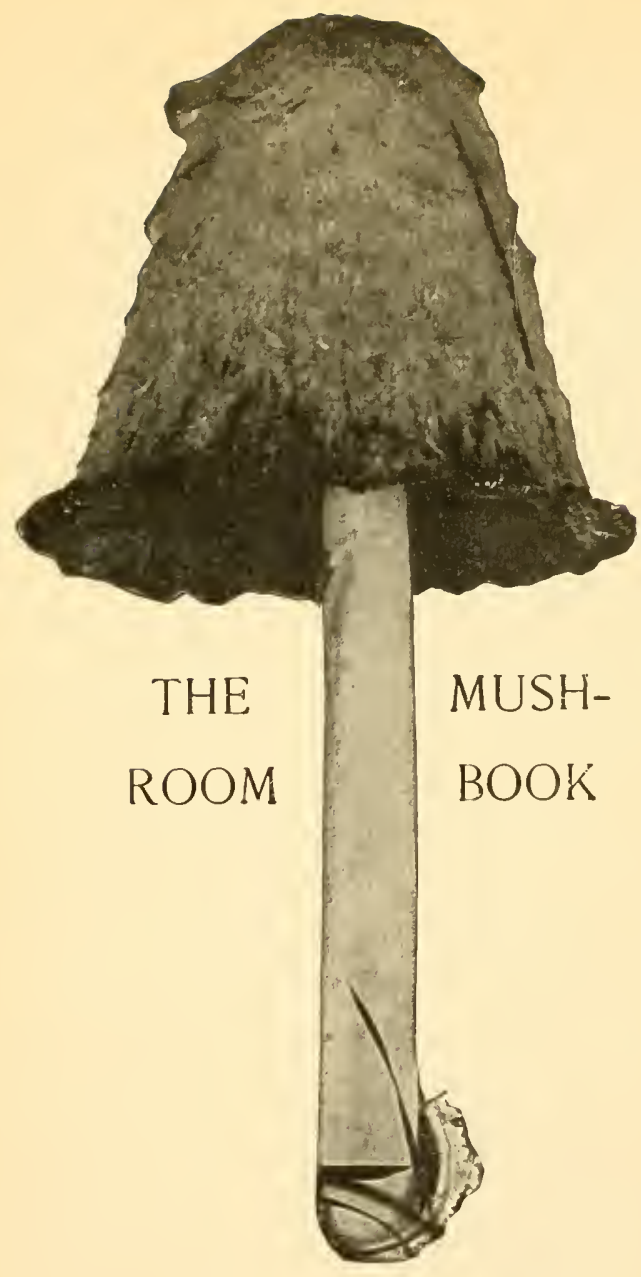

COPRINUS COMATUS

Courtesy of Agricultural Experiment Station, Corne" See page 90 



\section{PREFACE}

THE author of this book makes no claim to the discovery of the facts presented. The material has all been drawn from monographs written by men who have made specialties of the different divisions of fungi. A list of works consulted is given at the close of this book. The plates are reproductions of photographs made by Mr. J. A. Anderson, and coloured by Miss H. C. Anderson. They are as true to nature as it is possible to make them with the best methods of reproduction now known, and by them alone an acquaintance with many species may be acquired.

Many of the cuts have heen redrawn by the author from various reliable sources, and many have been drawn directly from nature. With a few exceptions, the line drawings of sections were made from the specimens photographed. It has been the aim of the author to write a book simple enough to serve als a source of knowledge for the many who, though husy with other pursuits, yet take an interest in science and wish to obtain information about the fungi, either for the sake of using them as food, or for the

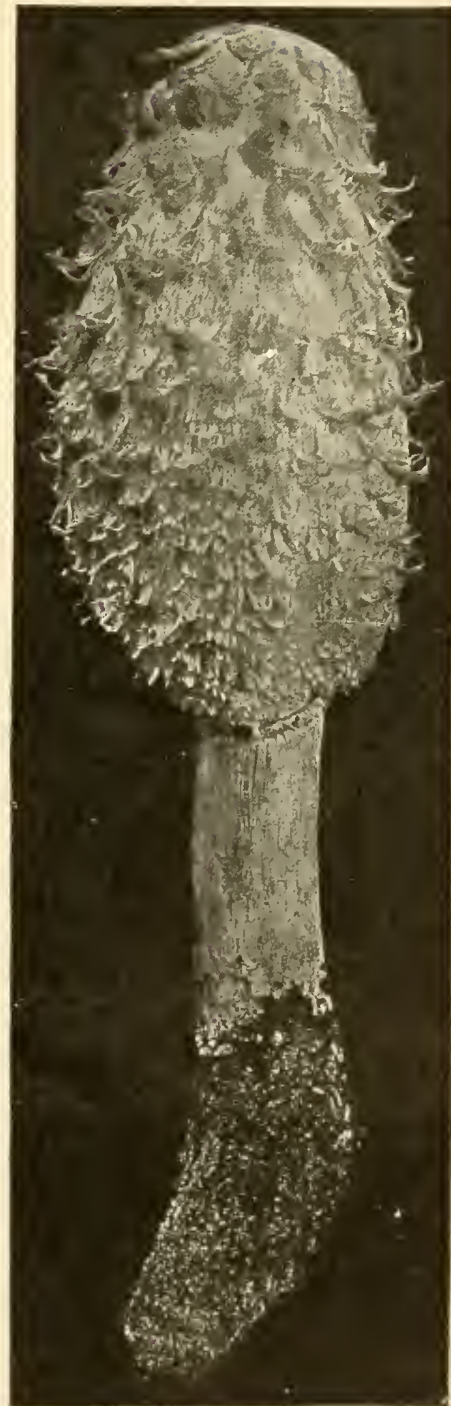

Coprinus comatus

Courtesy of Agricultural Experiment Station, Cornel University.

See page go 
pleasure which an acquaintance with their habits and home life may give. A great effort has been made not to sacrifice accuracy in îhis attempt.

The number of species of the fungi is so great that to describe them all would necessitite a bock of huge dimensions, so that it has seemed best simply to give a general idea of the characteristics upon which the larger groups, the clisses, orders, and generil, are based, by describing some of the species in each. Seven genera of the Spore-sac Fungi are illustrated with ten species, and thurty-five genera of the Basidomycetes with seventy-three species, making a total of eighty-three species represented by photographs in colour and half-tone.

In addition a number of species are given in rough pen drawings, with sufficient accuracy for identification, and many species have been described without illustration.

An effort has been made to describe the species in ternis intelligible to the average reader without constant reference to an unabridged dictionary, and, whenever possibie, the terms have been iilustrated by line cuts.

Although the technical names necessarily used are a serious hindrance to the popularization of the study of fungl, it has seemed best, in most cases, to give only the Latin form of the names of species, since, by so doing, there will be less danger of confusing harmless species with those which are harmful; and, also, if their Latin names are adhered to, one will find it much simpler to consuit the scattered literature on this subject, as this nomenclature is used by all naturalists of whatever nationality.

That the pronunciation of names maly be rendered as simple as possible, each vowel has been marked long or short. These vowel-marks are not necessarily indicative of the true syllabic quantity, but are rather diacritical points denoting the popular pronunciation by the English system. Each word has been divided into syllables according to the accepted rules, and an accent has been placed on the syllables to be accented,

The author is under deep obligations to Professor Lucien M. Underwood, of Columbia University, for aid and encouragement in the work of this book, and for his cheerful willingness at all times to assist in the search for material and in the work of revising proof. 


\section{Preface}

Thanks are also due to Professor Charles H. Peck, the New York State Botanist, for his kind assistance in identifying many of the specimens illustrated.

A list of books consulted has been placed at the end of the book, for the benefit of those who may wish to pursue the study furthe. 


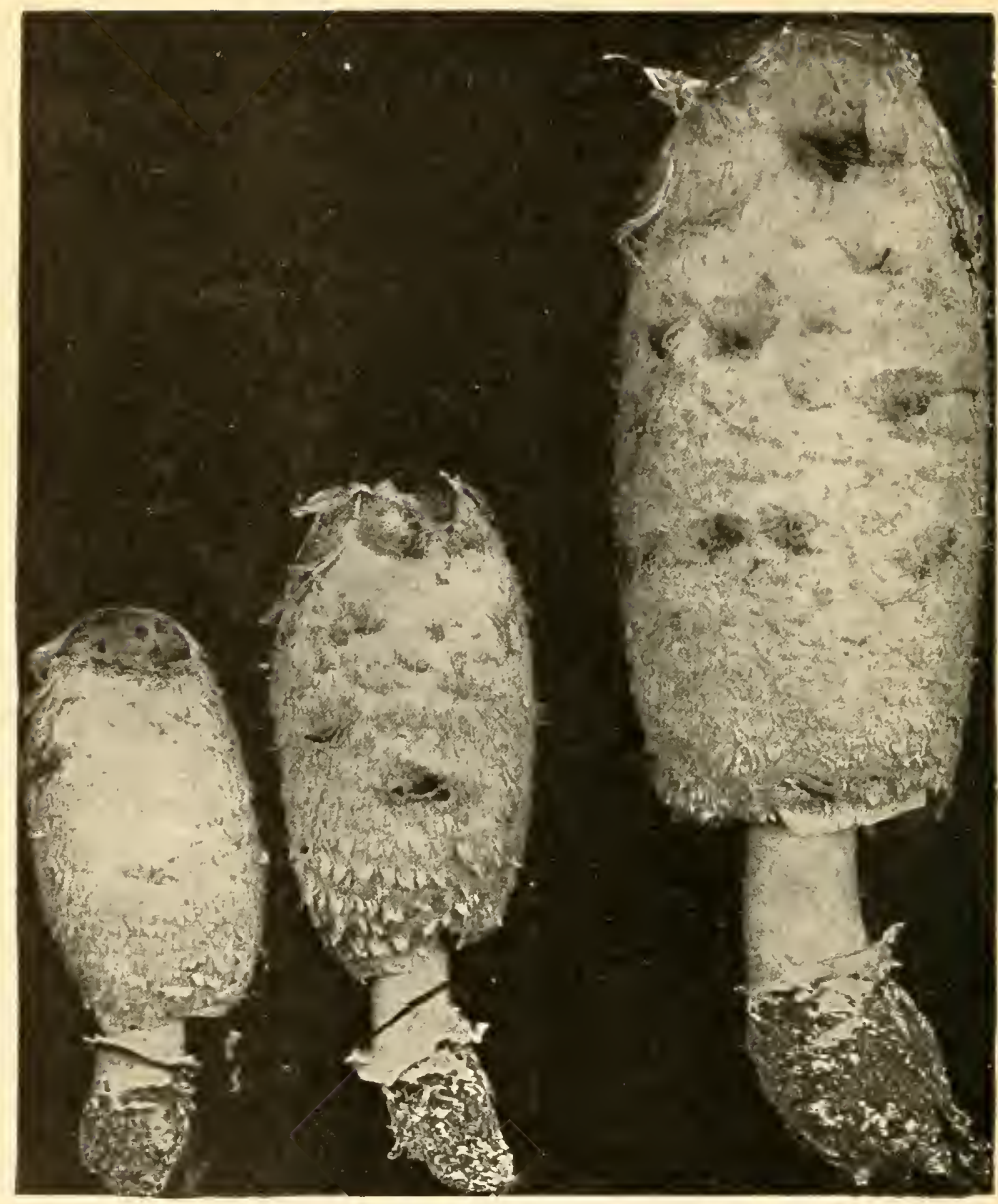

Coprinus comatus.

Lutrtesy of Agricultural Experiment Station, Cornell University.

See page on 


\section{CONTENTS}

CHAPTER I : The Homes and Habits of Fungl Page Chapter II: The Relation of Fungl to Other Plants 5 CHAPTER III : From SPORE to Mushroom . • 11 CHAPTER IV: THE KeY . . . . • . 15

What a key is, and why a name is desirable . 15

How a key for fungi is made, and why it is desirable . . . . . . . . 15

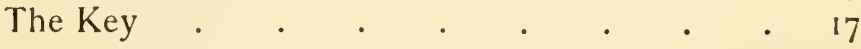

CHAPTER V: Fungl WITH GILls . • • • 46

1. WHITE-SPORED SERIES

Genus Amanita . . . . . . . . 46

Death Cup; Poison Amanita. . . . 48

Fly Amanita . . . . . . . . 49

Orange Amanita . . . . . . 50

Comparison of Three Yellow Amanitas . $\quad 52$

Gemus Cantharellus . . . . . . . 53

Cantharellus floccosus . . . . . 53

Genus Amanitopsis . . . . . . 53

The Sheathed Amanitopsis . . . . 54

Amanitopsis parcivolvata . . . . 55

Genus Mycena . . . . . . . 55

Mycena hæmatopoda . . . . . 55

Genus Lentinus . . . . . . . 56

Scaly Lentinus . . . . . . 56

Gemus Plenrotus . . . . . . . 57

Oyster Mushroom . . . . . . 57

Pleurotus sapidus . . . . . . 58

Elm Pleurotus . . . . . . . 58

Genus Hygrophorus . . . . . . 5

Chanterelle Hygrophorus . . . . . 59 
Vermilion Hygrophorus $\cdot \cdot{ }^{\circ} 60$

Ivory Hygrophorus . . . . . 61

Genus Armillaria . . . . . . . 61

Honey-coloured Armillaria . . . . 61

Genus Lepiota . . . . . . . $66_{3}$

Parasol Mushroom; Tall Lepiota . . . 63

Smooth Lepiota . . . . . . 64

Lepiota Friesii . . . . . . 65

Genus Marasmins . . . . . . 65

Fairy.ring Mushroom . . . . . 66

Genus Collybia . . . . . . . . . 66

Collybia familia . . . . . . . 67

Genns Panus . . . . . . . . 67

Genus Trogia . . . . . . 67

Genus Schiqophyllnm . . . . . . . 67

Genus Omphalia. . . . . . . . 68

Genus Russula . . . . . . . . 68

Emetic Russula . . . . . . 68

Green Russula; Verdette . . . . 69

Variable Russu!a . . . . . . 70

Genus Clitocybe . . . . . . . 70

Clitocybe laccilta . . . . . . 70

Clitocybe virens . . . . . 71

Genus Tricholoma . . . . . . . . 72

Masked Tricholoma . . . . . 72

Craterellus cantharellus . . . . . 73

2. BROWN-SPORED SERIES

Genus Agaricus . . . . . . . . . 73

Comparison of Eight Agarici . . . . 75

Common Mushroom . . . . . 76

Rodman's Mushroom . . . . . 76

Agaricus abruptus . . . . . . 77

Geulls Hypholoma . . . . . . . 78

Perplexing Hypholoma . • . . . 78

Comparison of Six Hypholomas . . . 79

Uncertain Hypholoma . . . . . 80

Hypholoma subliteritium . • . $\quad 81$

Genus Stropharia . . . . . . . 82 
Genus Psathyra . . . . . . . 82

Genus Psilocybe . . . . . . . 82

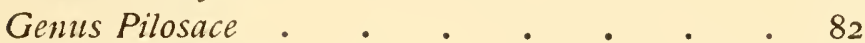

Genus Deconica . $\quad$ • . $\quad$ • $\quad$ • $\quad$ • 82

Genus Chitonia . . . . . . . $\quad \delta_{3}$

3. RUSTY-SPORED SERIES

Genus Pholiota . . . . . . . 83

Fat Pholiota . . . . . . . $\quad 83$

Early Pholiota.$\quad$. $\quad . \quad$. $\quad . \quad$. 84

Pholiota aggericola . . . . . $\quad$. 84

Genus Cortinarius . $\quad$. $\quad$. $\quad$. $\quad$. $\quad$. 85

Cortinarius alboviolaceus . • • . 86

4. PINK-SPORED SERIES

Genus Pluteus . . . . . . . $\quad$. 87

Fawn-coloured Pluteus . . . . . 87

Genus Entoloma . . . . . . . . 88

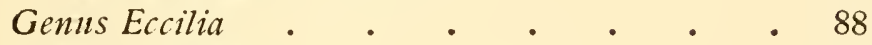

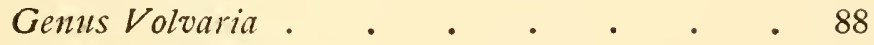

Genus Clitopilus . . . . . . . . $\quad$. 88

5. BLACK-SPORED SERIES

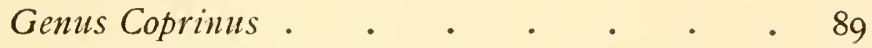

Ink Caps . . . . $\quad . \quad$. $\quad .89$

Shaggy-mane; Horsetail; Maned Agaric . 90

Inky Coprinus . . . . . . 91

Glistening Coprinus • • . $\quad$ • $\quad$. 91

Genus Gomphidius . • • . . . . 92

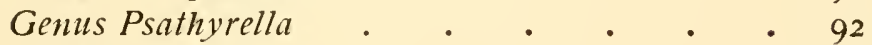

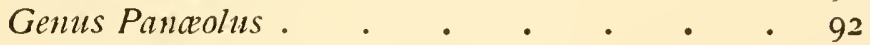

6. FUNGI WITH MILKY JUICE

Genus Lactarius . . . . . . $\quad$ • $\quad$ • 92

Peppery Lactarius . $\quad$ • $\quad$ • $\quad$ • $\quad$ • 92

Lactarius ligniotus. • • • • • 93

CHAPTER VI: Fungl with Teeth-Hydnace. . • 94

Genus Hydnum . . • • • . . 95

Spreading Hydnum • . • . . 95

White Hydnum . • • • • 


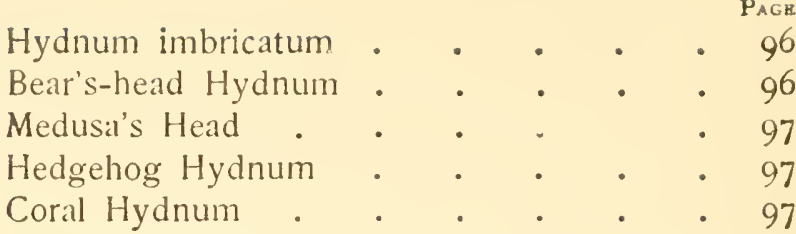

CHAPTER VII : Fairy Clubs and CORal. Fungl-Cla-

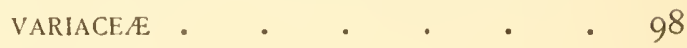

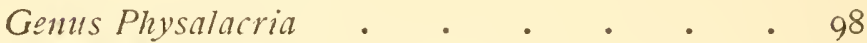

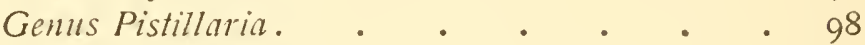

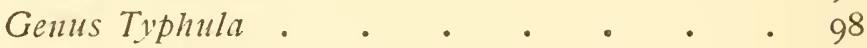

Genus Sparassis . • • • • . . . . 999

Genus Pterula . . • • • • • • . 99

Genus Lachnocladium. • • • .

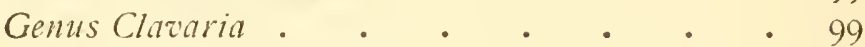

Pale Yellow Clavaria • • • • . $\quad$ • 99

Golden Clavaria . . . . . . 100

Red-tipped Clavaria . . . . . 100

Crested Clavaria . . . . . . . 100

Pistil Clavaria ; Large Club . . . . 101

Clavaria fellea . . . . . . 101

Clavaria formosa . . . . . . 101

CHaPter VIII : Fungl with Pores-Boletacea ; PolyPORACEA . . . . . . 102

Boletacece. . . . . . . . . 102

Genus Fistulina . . . . . . . . 102

Gemus Boletinus . . . . . . . 103

Painted Boletinus . . . . . . 103

Gemus Boletus . . . . . . . . 104

Boletus glabellus . $\quad . \quad$ • $\quad . \quad$. 104

Boletus bicolor . . . . . . 105

Boletus cyanescens . . . . . 105

Boletus pallidus . . . . . . 105

Boletus mutabilis . . . . . . 105

Boletus speciosus . . . . . . 105

Golden-flesh Boletus . . . . . 106

Boletus radicans . . . . . . 106

Boletus Peckii . . . . . . 106

Boletus calopus . . . . . . 106 
Purple Boletus . . . . . . 107

Boletus Satanus . . . . . . 107

Bitter Boletus . . . . . . 107

Boletus scaber . . . . . . 108

Orange-cap Boletus . . . . . 108

Chestnut Boletus . . . . . . 108

Boletus eximius . . . . . . 108

Edible Boletus . . . . . . . 109

Boletus subtomentosus . . . . . 109

Boletus Americanus . . . . . 109

Polyporacece . . . . . . . . . . 109

Genus Merulius . . . . . . . I10

Genus Polyporns . . . . . . . 110

Polyporus applanatus . . . 110

Polyporus fomentarius . . . . . 110

Polyporus conchatus . . . . . III

Polyporus velutinus . . . . . III

Polyporus pergamenus . . . . . I1

Polyporus perennis . . . . . III

Polyporus sulphureus . . . . . 111

Polyporus squamosus . . . . . 112

Polyporus lucidus . . . . . . 112

Polyporus arcularius . . . . . 112

Polyporus versicolor . . . . . 112

Polyporus circinitus . . . . . 113

Genus Trametes. . . . . . . 113

Genus Lenites . . . . . . . 113

Lenzites betulina . . . . . . 113

Lenzites separia . . . . . . 114

Genus Dodalea . . . . . . . . . 114

Drdalea unicolor . . . . . . . 114

Drdalea confragosia . . . . . 114

Dædalea quercinal . . . . . . 114 Genus Favolus . . . . . . 11;

CHAPTER 1X: Gelatinous and Other Fungi . . I16

Jew's Ear, or Judas's Ear . . . . . 116

Tremellodon . . . . . . . 116

Guepina . . . . . . . . 116 


\section{Contents}

CHapter X: Offensive Fungl-Order Phallales • • 117

Genits Phallus • . . • • • • • II7

Stinkhorns . . . . . . . 117

Phallus impudicus $\quad . \quad$. $\quad . \quad$. $\quad$. 119

Genus Dictyophora • • • . • . 120

Dictyophora Ravenelii . . . . . 120

Dictyophora duplicata . . . . . 120

Mutinus caninus . . . . . . 120

Family Clathracea . . . . . . . 121

Latticed Clathrus . . . . . . 121

Clathrus columnatus . . . . . 121

Anthurus borealis . . . . . . 121

Simblum rubescens . . . . . . 122

CHAPTER XI: PuffBalls • . • . • . 123

Order Lycoperdales . . • • • • . . 123

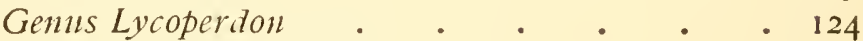

Pear-shaped Puffball . . . . . 125

Pinkish Puffball . . . . . . 125

Gemus Calvatia . . . . . . . . 126

Brain-shaped Calvatia . • . . . 126

Giant Puffball . . . . . . 127

Cup-shaped Puffball . . . . .

Genus Bovista . . . . . . . . . 128

Gemus Bovistella . . . . . . . . 129

Bovistella Ohiensis . . . . . 129

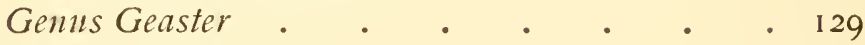

Earth-stars . . . . . . . . I 129

The Smallest Earth-star . . . . 130

Water-measuring Earth-star . . . . 130

Genus Calostoma . . . . . . . 131

Calostoma lutescens . . . . . . I I32

Calostoma Ravenelii . . . . . 132

Calostoma cinnabarinum . . . . 132

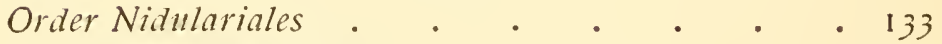

Genus Spharobolus . . . . . . 133

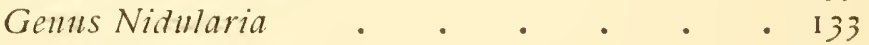

Gemus Cyathus . . • • • • • • 133

Genus Crucibulum . • • • • $\quad$. 133 
Order Sclerodermatales • . . . . . . 133

Genus Scleroderma . . . . . . . $\quad$. 133

Scleroderma vulgare • • . . . 134

CHAPTER XII : SPORE-SAC FUNGI-ASCOMYCETES • • 135

Order Tuberales-Truffles . . . . . . . 135

Order Hypocreales . . . . . . . . . 136

Genus Xylaria .

Order Sphariales . . . . . . . . 136

Order Pezizales-Cup-fungi • . . . . . 137

Peziza odorata

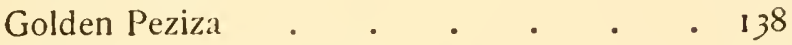

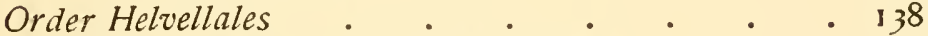

Family Geoglossacea-Earth Tongues . . . 138

Genus Spathularia • • • • • • • 138

Velvety Spathularia . • . . . 138

Spathularia clavata $\quad . \quad \cdot \quad . \quad . \quad .139$

Genus Geoglossum • • • • • • • 139

Geoglossum hirsutum • • • • • 139

Geoglossum glabrum . • • • • • 139

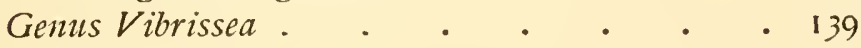

Vibrissea truncorum . . . . . 139

Vibrissea circinans $. \quad . \quad . \quad . \quad .140$

Genus Mitrula . • • • . . . 140

Irregular Mitrula . . . . . . 140

Family Helvellacea-Morels . . . . . 140

Genus Gyromitra . • • • • . . 141

Gyromitra esculenta . • . . . 141

Genus Morchella . . . • • . . 141

Genus Helvella . . • • . • . 142

Helvella elastica . . . . . . 142

Helvella lacunosa . . . . . . . 143

CHAPTER XIII : Slime Fungl-MyXomycetes • • . 144

CHAPTER XIV : Fungl FOR the HerbarIUm • • • 145

Collector's notes . . . . . • . . 145

Collector's outfit . • • • • • • . . 147

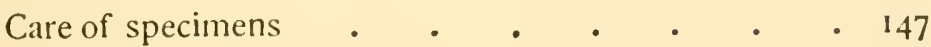

Collecting spores . . . . . . . . 147

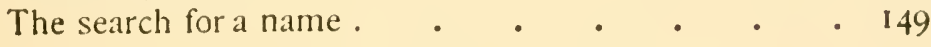




\section{Contents}

The preparation of rough-dried plants for the herbarium $\quad 149$ Mounting . . . . . . . . 149 Sections . . . . . . . . . 150

Poisoning herbarium specimens . . . . . 150

CHAPTER XV: Fungl for the Table . . . . 15 1

Calitions for the inexperienced . . . . . 151

The food value of fungi . . . . . . 152

To keep mushrooms temporarily . . . . 153

To prepare the edible agarics for cooking . . . 153

To toast agarics . . . . . . . . 153

To bake agarics . $\quad . \quad$. $\quad$. $\quad$. $\quad$. 153

To broil agarics . . . . . . . . . 153

Mushrooms stewed .

To prepare russulas . . . . . . . 154

To prepare fungi with milky juice . . . . 154

Lactarius deliciosus . $\quad . \quad$. $\quad . \quad$. 154

Lactarius volemus . . . . . . 154

To prepare amanitas . $\quad . \quad$. $\quad . \quad$. $\quad$. $\quad$ : 154

To prepare chanterelles . $\quad . \quad$. $\quad . \quad$. $\quad$. 154

To fry chanterelles . $\quad$. $\quad$. $\quad . \quad$. $\quad$. 154

To prepare coprini-ink caps . . . . . . 154

To prepare boleti . . . . . . . 154

To prepare Hydnum repandum . . . . . 154

To prepare morels . . . . . . . . 154

To prepare beefsteak fungus . . . . . . 155

For salad . . . . . . . . . 155

Minced . . . . . . . . 155

To prepare gyromitras . . • . . . . 155

To prepare woody pore-hearing fungi-Polypore . 155

To prepare clavarias and branched hydnums . . 155

To cook clavarias . . . . . . . 155

To prepare puffiballs . . . . . . . . 155

To cook puffballs . . . . . . . . 155

To cook the giant puffhall . . . . . . 155

Puffball salad . . . . . . . . . 155

List of Authorities Consulte! . . . . . 157

Abbreviations of Names of Botanists with Explanations . 159

INDEX and Glossary. . . . . . . . 161 


\section{LIST OF PLATES}

Plate

I. Amanitopsis parcivolvata, P.r. (see p. 55) Frontispiece

FACING PAGH

II. Death Cup; Poison Anıanita (Amanita phalloides, Fr.) 48

III. Fly Amanita (Amanita muscaria, L.), poisonous . 49

IV. Orange Amanita (Amanita Cæsarea, Scop.), edible . 50

V. Strangled Amanitopsis (Amanitopsis strangulata, Fr.

Roze), edible . . . . . . . 53

Vl. Sheathed Amanitopsis (Amanitopsis vaginata, Roze), edible . . . . . . . . . 54

VII. Helmet Mycena (Mycena galericulata, Scop.), edible 56

VIII. Scaly Lentinus (Lentinus lepideus, Fr.), edible • 57

IX. Oyster Mushroom (Pleurotus ostreatus, Fr.), edible (see p. 57) . . . . . . . 59

X. Golden-flesh Boletus (Boletus chrysenteron, Fr.)

(see p. 106) . . . . . . 6 60

Vermilion Hygrophorus (Hygrophorus miniatus, Fr.), edible . . . . . . 60

Chantarelle Hygrophorus (Hygrophorus cantharellus,

Schw.), edible (see p. 59) . . . . 60

XI. Fat Pholiota (Pholiota adiposa, Fr.), edible (see p. 83) 6I

Honey-coloured Armillaria (Armillaria mellea, Vahl.), edible . . . . . . . . 6 1

XII. Grainy Lepiota (Lepiota granosa, Morg.), • 63

XIII. Smooth Lepiota (Lepiota naucinoides, Pk.), edible 64

Parasol Mushroom (Lepiota procera, Scop.), edible

(seep.63) . . . . . . . . 64

XIV. Lepiota Friesii, Lasch . . . . . . 65

Cortinarius alboviolaceus, Fr. (see p. 86) - $\quad 65$

xvii 
PLATE

XV. Spotted Collybia (Collybia maculata, A. and S.) 66 Broad-gilled Collybia (Collybia platyphylla, Fr.) 66

XVI. Collybia familia, Pk. (edible) . . . . 67

Clitocybe laccata, Scop., edible (see p. 70) . 67

XVIl. Emetic Russula (Russula emetica, Schaeff.),

(dangerous) . $\quad . \quad . \quad . \quad . \quad 68$

XVIII. Green Russula (Russula virescens, Fr.), edible • 69

XIX. Deceiving Clitocybe (Clitocybe illudens, Schw.) 70

XX. Clitocybe virens, Scop. (edible) . . . . $7^{1}$

XXI. Masked Tricholoma (Tricholoma personatum,

Fr.; var. bulbosum, Pk.), edible . . . 72

XXII. Pholiota aggericola, Peck (see p. 84) • • $\quad 73$

Craterellus cantharellus, Schw. (edible) . . 73

XXIII. Agaricus campestris, L., edible (see p. 76) . 74

Agaricus abruptus, Pk. (edible) . . . . 74

XXIV. Field Mushroom (Agaricus campestris, L.), edible (uncultivated) . . . . . . 75

XXV. Rodman's Mushroom (Agaricus Rodmani, Pk.), young . . . . . . 76

Rodman's Mushroom (mature) . . . . 76

XXVI. Agaricus abruptus, Pk. (edible) • • • 77

XXVII. Perplexing Hypholoma (Hypholoma perplexum,

Pk.), harmless . • • • . . $7^{8}$

XXVIII. Uncertain Hypholoma (Hypholoma incertum, Pk.), edible . . . . . . , 80

XXIX. Brick Top (Hypholoma sublateritium, Schaeff.), edible . . . . . . . . 81

$\mathrm{XXX}$. Ivory Hygrophorus (Hygrophorus eburneus, Fr.), edible (see p. 61) . . . . . 84

Early Pholiota (Pholiota præcox, Pers.), edible . 84

XXXI. Dog Cortinarius (Cortinarius caninus, Fr.) • $\quad$. 85

XXXII. Zoned Cortinarius (Cortinarius armillatus, A. and

S., Fr.) • • • • • • • . 
XXXIII. Fawn-coloured Pluteus (Pluteus cervinus, Schaeff.), edible . . . . . 88

XXXIV. Inky Coprinus (Coprinus atramentarius, Fr.; var. silvestris, Pk.), edible (see p. 91) . 89

XXXV. Inky Coprinus (Coprinus atramentarius, Fr.), edible . . . . . . . 90

XXXVI. Mycena hæmatopoda, Pers. (see p. 55) . 92 Lactarius ligniotus, Fr. $\quad$ • $\quad$ • $\quad$ • 92

XXXVI1. Peppery Lactarius (Lactarius piperatus, Scop.), edible . . . . . . 93

$X X X V 111$. Bear's-head (Hydnum caput-ursi, Fr.), edible . 96

XXXIX. Coral Hydnum (Hydnum coralloides, Scop.), edible . . . . . . . 97

XL. Little Tongue Clavaria (Clavaria ligula, Fr.) . $\quad 9^{8}$

XLI. Golden Clavaria (Clavaria aurea, Schaeff.), edible . . . . . . 100

XLII. Clavaria formosa, Pers., edible • . . 104

XLIII. Cone-like Boletus (Strobilomyces strobilaceus, Berk.) . . . . . . 104

XLVI. Painted Boletinus (Boletinus pictus, Pk.), edible 105 Spreading Hydnum (Hydnum repandum, L.), edible (see p. 95) • • • . . 105

XLV. Bitter Boletus (Boletus felleus, Bull.; var. obesus, Pk.) . . . • . . 107

XLIV. Scabrous-stemmed Boletus (Boletus scaber, Fr.; var. niveus, Gill.) . . . . . 108

XLVII. Tinder-wood Polyporus (Elfingia fomentaria, L., Fomes fomentarius, Gill., Polyporus fomentarius, Fr.) • . . . . $\quad 110$

XLVIII. Polyporus versicolor, Fr. • . • • 112 Polyporus circinatus, Fr. (see p. 113) . . 112 XLIX. Lenzites betulina, Fr. . . . . . 113

L. Dædalea quercina, L., Pers. . . . 114

Ll. Jew's Ear (Hirneola auricula-Judæ), L., Berk. . ${ }_{116} 6$ xix 
Ll. Xylaria (see p. 136) . . . . . . 116

L.11. Phallus impudicus, L. . . . . . . 119

L111. Pear-shaped Puffball (Lycoperdon pyriforme,

Scliaeff.), edible . . . . . . . 124

LIV. Brain Puffball (Calvatia craniformis, Schw.), edible . . . . . . 126

LV. Bovistella Ohiensis (Ellis and Morgan), edible (see p. 129). . . . . . . 129

Cup-shaped Calvatia (Calvatia cyathiformis, Bosc), edible. . . . . : 129

LY'l. Calostoma Ravenelli, Berk., Mass. . . . 130 Calostoma lutescens, Schw., Burnap . . . 130 Calostoma cinnabarinum, Desv. . . . 130 Spathularia velutipes, C. and F. (see p. 138) . . 130

LVI1. Least Earth-star (Geaster minimus, Schw.) • . 130 Water-measuring Earth-star (Geaster hygrometricus, Pers.) . . . . . . 132 Bird's Nest (Cyathus vernicosus, D. C.) (see p. 133) . . . . . . . 132

LVII]. Flesh-coloured Pufiball (Lycoperdon subincarnatum, Pk.), edible (see p. 125) . . . I35 Young Pear-shaped Puffball (Lycoperdon pyriforme, Schaeff.), edible (see p. 125) . . 135 Hard-skinned Puffball (Scleroderma vulgare, Fr.) 135

LIX. Cordyceps capitala (Holmsk., Lk.), parasitic on Elaphomyces . . . . . 136 Lycogola epidendron (see p. 144) . . . . 136 Floccose Chanterelle (Cantharellus floccosus, Schw.), edible (see p. 53) . . . 136 Mutinus caninus, Huds. (see p. 120) . . . 136

LX. Slippery Leotia (Leotia lubrica), edible . . . 137 Jelly-like Tremellodon (Tremellodon gelatinosum) 137

LX1. Golden Peziza (Peziza aurantia, Pers.), edible . 138 
LXI. Peziza odorata, Pk., edible (see p. 137) . . 138

f.XII. Helvella elastica, Bull. (see p. 142) . . . 140 Helvella lacunosa, Holm. (see p. 143) . . . 140 Mitrula vitellina, Sacc., var. irregularis, Pk. . . 140

LXIII. Delicious Morel (Morchella deliciosa, Fr.), edible . 142 Polyporus arcularius, Batsch, Fr. (see p. I12) • 142 1.XIV. Bristly Panus (Panus strigosus, B. and C.) (see p. 67). . . . . . . . 145 



\section{LIST OF ILLUSTRATIONS IN TEXT}

Coprinus comatus, Fr. (old) Coprinus comatus, Fr. (mature) • • • • • • v Coprinus comatus, Fr. (young) • • • • • • viii Puffball . . . . . . . . . . . 4, 25 Corollas and honey, attractive to insects . . . 5

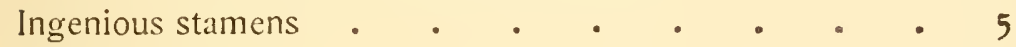
Pistil of violet . . . . . . . . . 6 Seed-box of iris . . . . . . . . . 6 Pistil of St. Johnswort • • • • • . . 6 Seed-box of sacred bean . . . . . . 6 Winged seed of the silver fir . . . . . . 6 Fern with spores (Polypodium vulgare) • . . . 6 Grass spikelet • • • • • • • • • 7 Liverwort (Marchantia polymorpha) • . • • $~ 7$

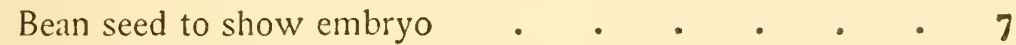

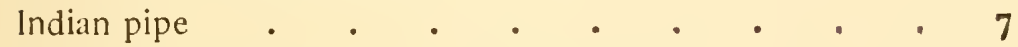
Moss (Dicranum scoparium) (natural size) • • $\quad$. 8

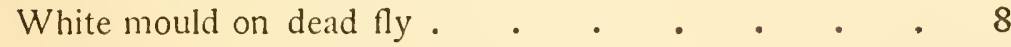
Spores borne in delicate membranous sacs . . . . . 9. 17 Bread mould . . • • • . . . • 9 Spores borne on little spicules . . . . . . 9, 17

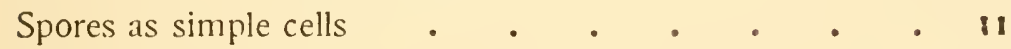
Spores divided into several cells ${ }^{\circ}$. . . . 11 Mycelial threads . . . . . . . . II Mushroom buttons . . . . . . . . st

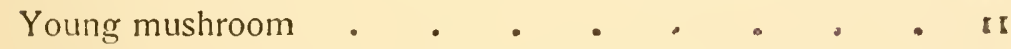
Puffball . . . . . . . . . 12 
Mushroom to show veil • • • • • 12

Mushroom to show calp, ring, gills, and stem . $\quad$. 12

Mushroom to show veil on stem and calp . • • 12

Section across gill (magnified) • • • • • • 12

A smali portion of section of gill (highly magnified) • 13

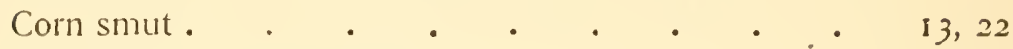

Leaf rust on Hepatical triloba . • • • • 13,22

Pouch-fungus, section to show spores in hollow rind $\quad 14$

Section to show gills . . . . . . . . 14

Section of a Boletus, to show pores . . . . 14, 102

Clavaria with spores on spines . $\quad . \quad \cdot \quad \cdot \quad$ 14

Section of Hydnum, to show teeth . • . . 14

Section of stroma with perithecial (magnified) • • . 18

Perithecium (highly magnified) . • • • • 18

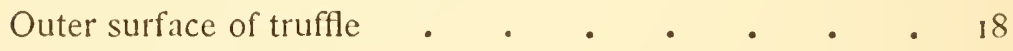

Section of truffle $\quad$. $\quad . \quad . \quad . \quad$. 18

Fleshy cup-like fungi . . . . . . 19,20

Club-shaped fungus . $\quad$ • $\quad$ • $\quad$ • 19, 21

Conic, convex, and pitted fungus . . . . 19-21

Fungus with gyrose furrows . . . . . 19.20

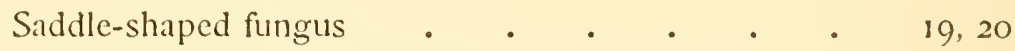

Fungus with spore surface flat, running down the sides . 21

Fungus with gills $\quad . \quad$ • $\quad$ • $\quad$ • 22, 30

Fungus with pores • • • • • • • 23,42

Fungus with spines . $\quad$ • . . . . . 23

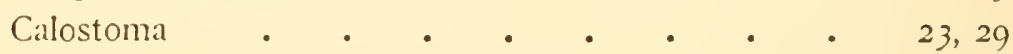

Geaster • • • • • • • • 23,28

Nidularia • • • • • • • • • 23,24

Clathrus cancellatus . • . • . . 24, 26, 121

Simblum rubescens . . • . . . $24,26,122$

Anthurus borealis . . . . . . $\quad$. 24, 26, 121

Mutinus . $\quad$ • $\quad$ • $\quad$ • • • • 27

Phallus impudicus . $\quad$. $\quad$ • $\quad 24,27,119$ 
Embryo plant of Mutinus caninus

Scleroderma vulgare

Section of Scleroderma vulgare . . . . . 25,134

Mutinus caninus, young plant; embryo plant . . . 120

Bovista . . . . . . . . 28, 128

Section of Bovista (diagrammatic) . • . • 28, 128

Calvatia . . . . . . . . 28, 126

Section of Calvatia • • • • • • • 28, 126

Geaster • • • • • • • • • • 28

Lycoperdon . • • • • • • • • • 29

Section of Lycoperdon (diagrammatic) • • • $\quad$ 29, 124

Bovistella . . . . . . . . . 29

Section of Bovistella . . . . . . . 29, 129

Clavaria . . . . . . . . . . 30

Section of Hydnum . $\quad . \quad$ • . . 30

Cap of Hydnum imbricatum . • • • • • • • • • • • • • • • •

Cap with striations on the margin . . $\quad \cdot 30,40,50$

Bracket fungus . • . . . . . . 31

Resupinate fungus . . . . . . . 31

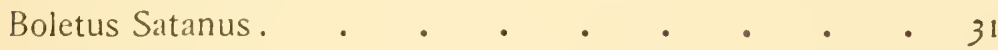

Polyporus quercina . • . . . . . . 31

Pleurotus, stem central . . . . . . . . 32

Pleurotus, stem eccentric . • . • . . . 32

Pleurotus, stem wanting . • . • • • 32

Gills toothed, Lentinus . . . • • • . 32

Lamellæ entire . . . . . . . . . . 33

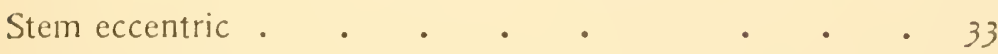

Lamellæ simple . • . . . . . . . 33

Fungus with volva and annulus . . . . . 34

Volva, but no annulus . $\quad . \quad$. $\quad . \quad$. 34

Annulus, but no volva $\quad . \quad$ • $\quad . \quad$ • 34

Lamellze free from stem . . . . . . . 34,39

Annulus movable $. \quad . \quad$. $\quad . \quad$. 34 


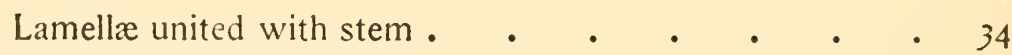

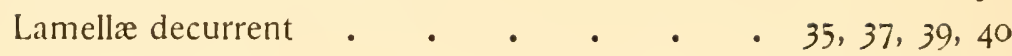

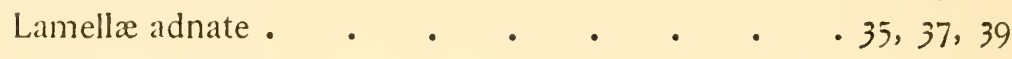

Lamellæ sinuate . • . • • • • • • 35

Volva wanting; annulus wanting $. \quad . \quad . \quad . \quad 35$

Lamellæ in shallow folds . . . . . . . 36

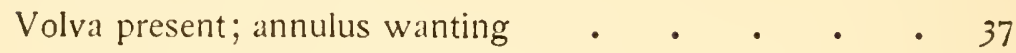

Volva none; annulus none. $\quad . \quad$. $\quad . \quad$. 37

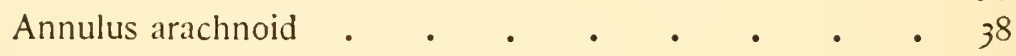

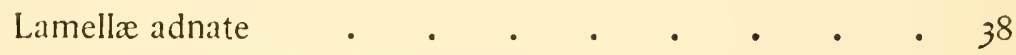

Veil remaining on stem as annulus . $. \quad . \quad . \quad 39$

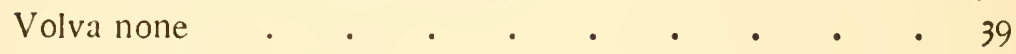

Veil attached to margin of pileus . . . . . $\quad$. 39

Lamellæ deliquescent $\quad$ • $\quad$ • • . • 40

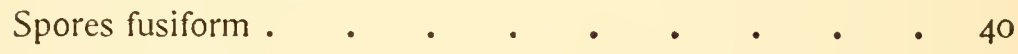

Spores globose • • • • • • • • 40

Hydnum with central stem . . . . . . 41

Branched Hydnum ..$\quad$. $\quad . \quad$. $\quad . \quad 41$

Lamellæ labyrinthine, woody . . . . . . 43

Lamellæ radial, woody . . . . . . . 43

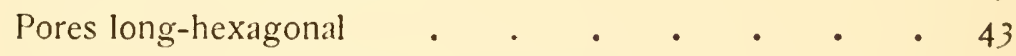

Pores in the form of tubes, stem lateral . . . 44

Pores in the form of tubes, stem central . . . . 44

Section of young Amanita in wrapper . . • 47

Young Amanita in wrapper . $. \quad . \quad . \quad . \quad 47$

Young Amanita in ruptured wrapper $\quad . \quad$. 47

Section of Amanita muscaria . . . . . . 47

Cap striate, and free from warts..$\quad$. . . 50

Section of Amanita Cæsarea $\quad . \quad$. $\quad . \quad$. 50

Young plant of Amanita Cæsarea . . . . . 50

Section of Cantharellus floccosus . . . . $\quad 53$

Section of Amanitopsis vaginata $\quad$. . . . 54

Section of Amanitopsis parcivolvata . . . • $\quad$ • 55 
Section of Lentinus lepideus . • • • • 56

Section of Pleurotus ostreatus . $\quad . \quad$ - $\quad$. 5 ?

Section of Pleurotus sapidus • • • • • 58

Section of Pleurotus ulmarius . $\quad$ - $\quad$ • 59

Section of Hygrophorus miniatus . • . . 60

Section of Hygrophorus eburneus . • • • 6 1

Section of Armillaria mellea . • . • . 62

Section of Lepiota procera . . . . . . 63

Section of Lepiota naucinoides . . . . . 64

Section of Collybia familia . • . • • • 67

Section of Russula emetica . • • • • • 68

Section of Russula virescens . • • • • $\quad$ • 69

Section of Clitocybe laccata $\quad$ • • • • 7 I

Section of Tricholoma personatum (var. bulbosum) • $\quad 7^{2}$

Section of Craterellus cantharellus . • . . 73

Section of Agaricus Rodmani . • • • • 76

Section of Agaricus abruptus • • • • • 77

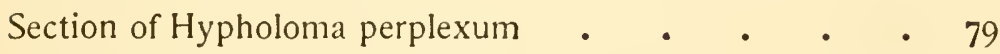

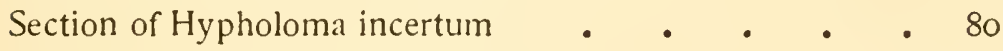

Section of Hypholoma sublateritium . • • • 8 i

Section of Pholiota adiposa . . . . • 83

Section of Pholiota præcox • • • • • • 84

Section of Cortinarius violaceus . • • • • • 86

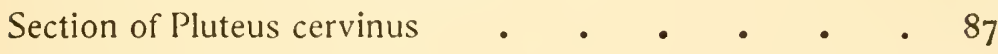

Section of Lactarius piperatus • • • • • 93

Section of Hydnum repandum • • • • • 95

Section of Hydnum caput-ursi • • • • • • 96

Boletus Satanus . $\quad$ • • • • • • 107

Under surface of Lenzites betulina $\quad$ - $\quad$ • 113

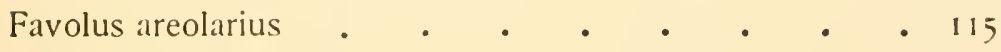

Section of young phallus ..$\quad \cdot \quad \cdot \quad \cdot \quad \cdot 119$

Mutinus bambusinus . • • • • • • 120

Lycoperdon . $\quad$ • . . . • • 124

xxvii 
Section of Lycoperdon (diagrammatic) • . • . 124

Asci and paraphyses . . . . . . . 135

Section of truffle to show position of asci . . . $\quad$. 135

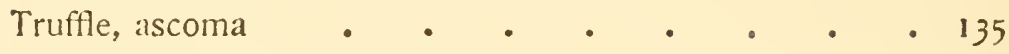

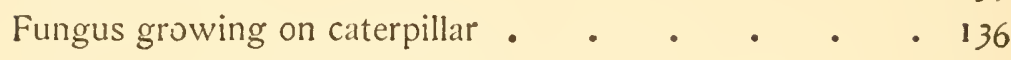

Section of Peziza odorata to show two layers . $\quad . \quad 137$

Gyromitra esculenta • • • • • • • • 141

Morchella esculenta • • • • • . • 141

Section of Morchella deliciosa . . . . . . 141

Helvella • • • • • • • • • 142

Helvella lacunosa (diagrammatic) . . . . . 143 


\section{THE MUSHROOM BOOK}

\section{CHAPTER 1: THE HOMES AND HABITS OF FUNGI}

FOR centuries epicures have used certain fungi for food. The Greeks and Romans esteemed them highly, and gave a great deal of consideration to favourable times and places for gathering them, and to choice methods of preparing them for the table. Juvenal tells us of one old Roman enthusiast who was so carried away by his love for them as to exclaim, "Keep your corn, $O$ Libya, unyoke your oxen, provided only you send us mushrooms!" Horace says that mushrooms which grow in the fields are the best, and that one can have but little faith in other kinds. Mushroom eaters of the present day would perhaps not agree with him, for they find edible species in every imaginable place where fungi grow, and are constantly adding to their list new varieties which they esteem delicious.

Although for centuries it has been known that some fungi contain most virulent poisons, still, through ignorance of those points which distinguish the poisonous from the edible, frequent cases of poisoning occur in all classes of society. The mistakes resulting in death have been frequent enough to inspire the timid with an overpowering dread of all fungi, while the damp and grewsome places in which many fungi flourish have caused them to be despised by others. The following lines from Shelley very aptly express the general sentiment :

"And plants, at whose names the verse feels loath, Fill'd the place with a monstrous undergrowth, Prickly and pulpous, and blistering and blue, Livid, and starr'd with a lurid dew. 
"And agarics and fungi, with mildew and mould, Started like mist from the wet ground cold ; Pale, fleshy, as if the decaying dead With a spirit of growth had been animated."

Shelley: "The Sensitive Plant."

To many people the only growths known as fungi are toadstools and mushrooms. They give the name mushrooms to the species known to them as edible, and regard all other similar growths as toadstools, things uncanny or poisonous.

"The grisly todestool grown there mought 1 see, And loathed paddocks [toads] lording on the same."

SPENSER's "Faerie Queene."

This distinction has no scientific basis, and in fact most of the species called toadstools are edible. Fungi are not always the grewsome things of Shelley and Spenser. In their ranks are many which delight the eye with their colouring and the symmetry of their forms. They are the grotesques of nature; nests, hoofs, cups, umbrellas, shells, and clubs are represented, together with spheres, hemispheres, cones, and many other geometrical figures. The mildew on the linen, the mould on food, the rusts and smuts which blight our fields of grain, and the dry rot which crumbles our lumber to dust and which causes old wood in dark places to glow with a weird, pale, flickering light, are all forms of one group or another of these plants which prey upon living or dead organic matter. In ordinary observation, only the simpler and more noticeable fungi are taken into account, but they are in reality met with in almost every situation imaginable. They are found in damp cellars and in rooms shut off from the light; in fact, some form of fungus will be found in every place and on everything which is not exposed to a circulation of fresh air.

In woods and open fields the attractive forms are found. In shady woods the beautiful white "bear's head" hangs on stately tree trunks, and the "destroying angels" gleam white in the shadows on the ground. Shelving brackets, green or red or brown, encircle old stumps, or stand out stiff and white from the crumbling trunks of fallen moss-grown monarchs of the forest, while wood-brown toadstools huddle in groups among 
the allen leaves. On the outskirts of the wood, green and red Russulas vie with the flowers in the brilliancy of their colouring. Pink or violet Clavarias, dainty corals, border the wood path, and golden Clavarias lighten up the sombre wood tints with their yellow branches. In dry pastures and along wood roads, puffballs, large and small, send up their puffs of brown smoke, to the delight of every passing child who strikes them with a wand. On lawns and hillsides the Oreades cause fairy rings to grow. The fairy rings are circles, or parts of circles, of impoverished grass of a lighter colour and less luxuriant growth than that of the grass immediately surrounding the circle. Before the existence of fairy folk came to be doubted, it was firmly believed that these fairy rings were the dancing grounds of the fairies.

"The nimble elves

That do by moonshine green sour ringlets make Whereof the ewe bites not; whose pastime 'tis To make these midnight mushrooms."

Rev. Gerard Smith.

The rings on the commons increase in size until sometimes two or more rings intersect to form a labyrinth of green network. Rings appear year after year in the same place, and then disappear, to reappear after an interval of a few seasons. As long as the fairies existed in the imaginations of the people, it was easy to account for these strange happenings-the fairies danced in the moonshine, and the grass was worn down under their feet. If they were displeased and left the neighbourhood, the rings disappeared too. As this fancy was given up, other solutions of the mystery were sought. Some believed that the ring was caused by a thunder-bolt entering the ground at this spot, and still others were confident that it was caused by moles. The true solution is not hard to find, to one familiar with the habit of growth of the fungus plant. One fungus plant growing alone upon the lawn will soon exhaust the soil directly beneath it of all true fungus food. Of all the spores which fall from the parent plant only those will grow which fall without this impoverished spot, and so a ring of toadstools is formed. Again, only those spores which fall outside the ring will find good fungus food, and so the ring widens always cutward, forming a perfect circle, unless something on one side or other interferes with its travels. The 
decaying ring of fungi temporarily stimulates the grass around it, so that its rich colour stands out in circles or alrcs of circles against the less highly nourished grass. Such rings are conspicuous on the lawns of the White House at Washington, and are often to be seen well defined on distant hillsides.

Brackets and mushrooms and puffballs grow in warm, moist places where they find decaying wood and leaves to feed upon. Old tree trunks and fallen logs, rich leaf mould, and cattle pastures are their favourite haunts.

The reason for their choice of place is invariably connected with the question of food, for fungi can thrive only where they can obtain organic matter, as they have lost the power which all green plants have of feeding on inorganic or mineral matter. All plants must have food with which to form plant flesh. Green plants by means of their leaf green--the only agent in the world which has the power to turn lifeless mineral matter into living matter-take the element carbon from the air, and hydrogen gas and oxygen gas from water, and with their green granules, by some mysterious process, make of the elements hydrogen, oxygen, and carbon, compounds of wood and starch and sugar. Fungus plants have none of this leaf green and must therefore feed on material which has been manufactured by green plants.

To define fungi simply, so as to include all the varieties, would be a difficult task; but in general it maly be said that they are plants which have no leaf green and which do not grow from true seeds, but from dustlike bodies resembling in appearance the yel-

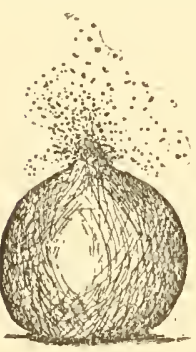

Puffball low pollen of roses or lilies.

The fungi have no flowers and produce no seeds. They produce spores instead, fine dust-like particles, which are borne in special places on the mature plant, whether a mould or mildew. a toadstool, puffball, or bracket. The cap of a mushroom placed right side up on a piece of paper under an inverted glass will print with its spores a picture of the radiating leaves or gills beneath. A slight blow on a puffball in the pasture will cause a puff of smoke-like dust to rise from it-really millions of spores that have ripened inside the puffball and are now ready to grow into new puffball plants when they fall on favourable soil. 


\section{CHAPTER II : THE RELATION OF FUNGI TO OTHER PLANTS}

A CLASSIFICATION or orderly arrangement of material collected for study is indispensable to true pieasure and profit. The nature student must classify both his specimens and the knowledge he

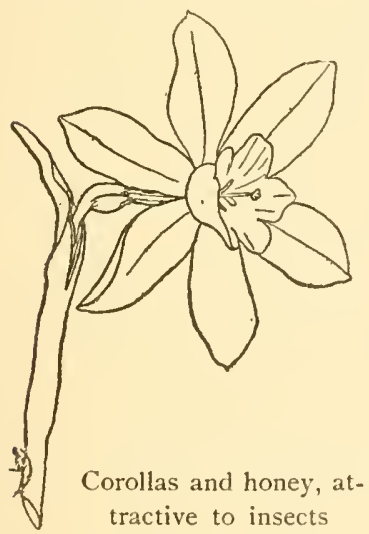
may obtain about them; for, as Spencer has said, "When a man's knowledge is not in order, the more of it he has the greater will be his confusion of thought." As he compares his specimens he sees interesting gradations of resemblance, and becomes fascinated with the pleasure of tracing their relationships and the gradual evolution of higher forms from lower.

Every lover of nature who haunts the fields and woods acquires a rich store of facts about plant life, and without, perhaps, recognising that he does so, distinguishes two great groups of plants-those which have attractive flowers, and those which have no flowers at all. His flowerless plants bear no seeds, but quantities of fine, dust-like particles which rise in the air as he brushes his stick over their green leaves. As the powers of observattion develop, he distinguishes the ferns and Christmas greens among flowerless plants, and perhaps soon recogrnises that

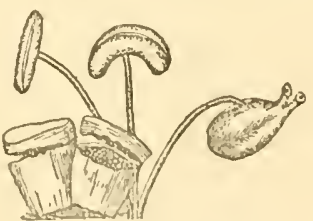

Ingenious stamens the soft green moss bank, too, is composed of small plants, and that the green mats, the liverworts, on stones and moist banks and logs, are plants also. His only reason, perhaps, for calling them plants is that they grow and are green. He may 
learn with the microscope that the pond scums which he had thought discrusting frog-spittle are in truth tangles of exquisite

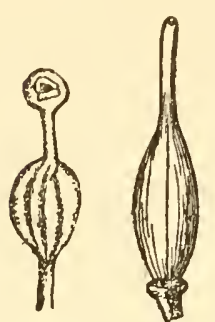

Pistil of Pistil of violet St. Johnswort plants, made up of chains of slender, transparent cells finer than silken threads, each cell containing many tiny green particles of leaf green, or chlorophyll-the cause of the green colour of all green plants.

At first the most conspicuous plants attract the attention, and afterwards, in succession, those less and less conspicuous. They, in reality, present themselves in great natural groups, readily distinguished by well-marked characteristics.

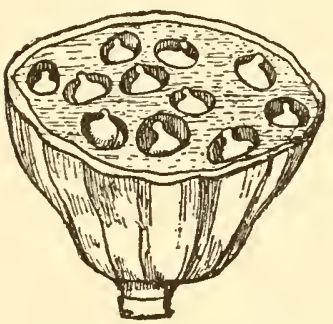

Seed-box of sacred bean

It will be seen, as these pass in review, that they are conspicuous according as

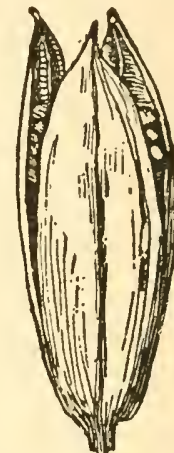

Seed-box of iris they are complex. The gorgeous flowering plants have complicated methods of reproduction - corollas and honey, attractive to insects ; ingenious sta-

mens, pistils, seed-boxes, and seeds. The humble grasses, with their close

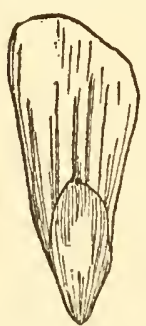

Winged seed of the silver fir with wings for dissemination, and leave them exposed to the wind.

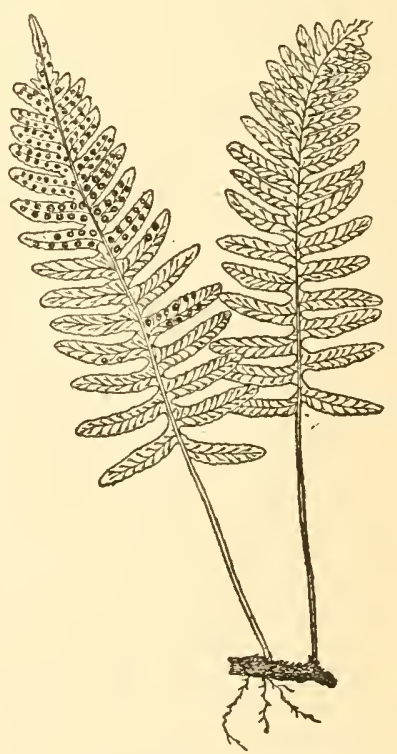

Fern with spores (Polyponum vulgare) 
The ferns and Christmas greens (Lycopodiums) have no flowers, and therefore no true seeds. They have a distinct stem, which grows from the apex and is strengthened by woody fibres, which may readily be seen by breaking the stem across. The woody fibres so strengthen the tissues of these plants that they are able to stand erect and make a conspicuous appearance not pos-

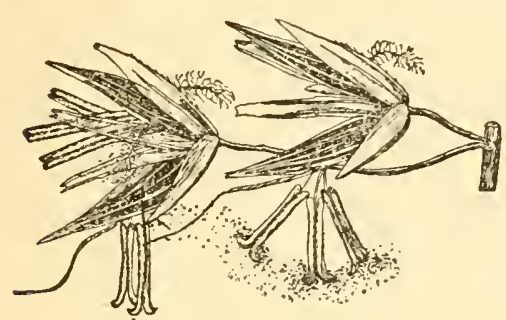

Girass spikelet

sible to the small mosses and liverworts, which are

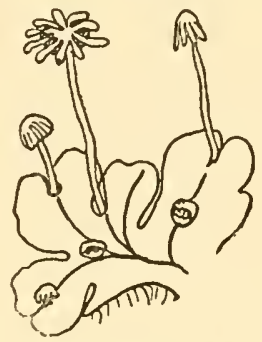

Liverwort (Marchantia polymorpha) spore-bearing plants with no woody fibre.

The plants of all these groups resemble each

other in descending degrees, so that they may be classed in groups under groups. Similar specimens may form groups of species. Species may form larger groups, or genera. Genera with common characteristics may form families ; and groups of families, orders; and orders, classes; while classes unite to form branches, or phylæ.

A botanist relies for the classification of

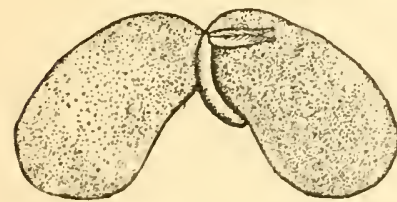

Bean seed open to show embryo

his specimens mainly upon the similarity of those parts of the plant which produce the seeds or spores rather than upon those parts-the roots and leaves and stems-which have the work of the plant household to do. He finds that the seed and spore producing parts are more con-

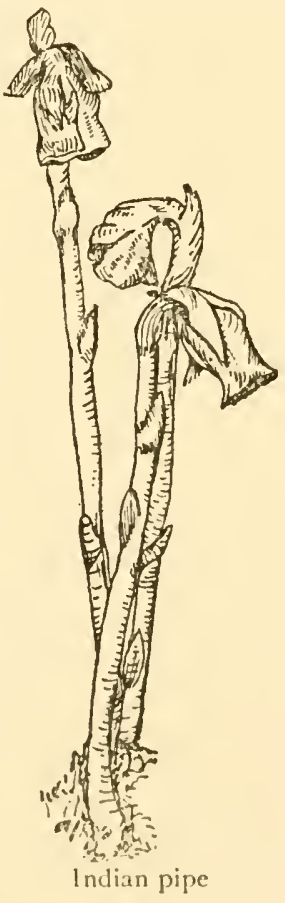
stant in their forms and habits than the leaves and stems and roots, which are more exposed, and which are constantly 
being forced to a change of form which will better suit their changed surroundings.

The novice sees nothing in the brown, or even in the highly

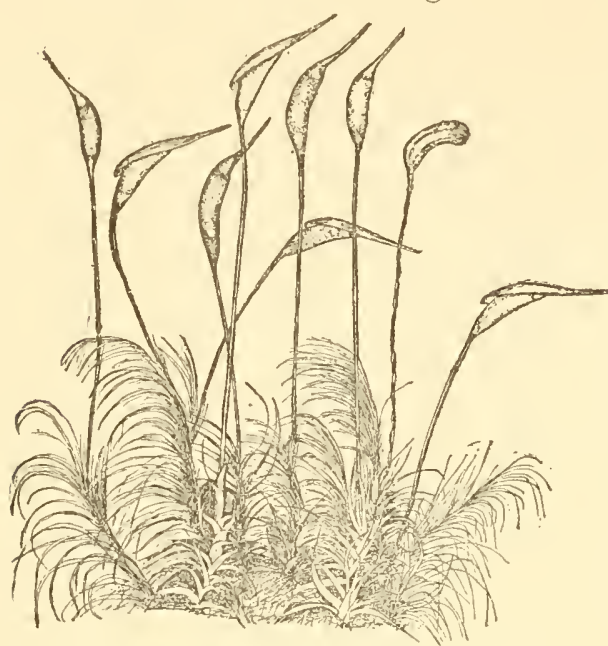

Moss (Dicranum scoparium) (natural size) coloured, fungi to warrant his calling them plants. They are to him "just toadstools;" for green colouring matter -his first criterion for plants - is not there, and, moreover, there is nothing in their shape which suggests to him the plants with which he is familiar. The snowwhite Indian pipe lacks the green of most plants, but that does not rule it for him out of the plant world; for although it is colourless, and depends upon other plants for food, still it has a flower form and produces a seed-box with well-developed seeds. Fungi, however, to any but the close student must seem quite unrelated to all normal plant forms. But the botanist, by a study of their structure, finds that they all grow from microscopic, dustlike particles, which differ from true seeds in consisting of but one or a few cells, and in having no embryo plant in them as true seeds have. He recognises their position in the kingdom of living things, and classes them as spore-bearing plants, lower than the group of mosses, those dainty plants which delight every one with their gracefulness, and which bear their spores in tiny cap-

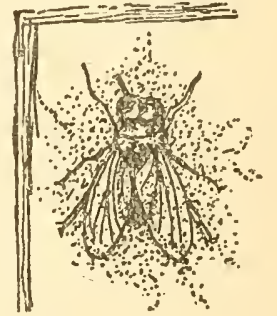

White mould on dead fly sules or boxes set up on slender stems. By studying their life history he decides that they are degenerate members of the lowest group - the algx-and that they have fostered the habit of feeding on material constructed by green plants, instead of constructing food material for themselves, and have, in consequence, 
lost their power of constructing such food, and also their green granules by which this work of construction may be carried on. The life history and structure of fungi has been studied so minutely that one is Sporecases able to arrange them in three wellmarked classes:

The first class, the algal-like fungi (Phycomycetes), includes bread moulds and several of those fungi which caluse diseases of plants and animals-the downy mildew on the grape, the potato rot, the common white mould which fastens dead flies to the walls or window panes in the autumn, and the fungus which grows on salmon

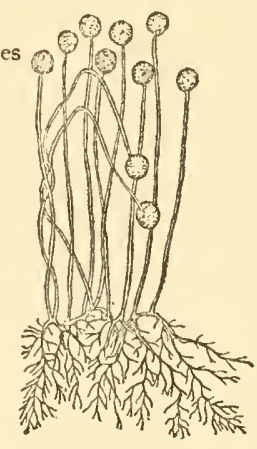

Bread mould (magnified)

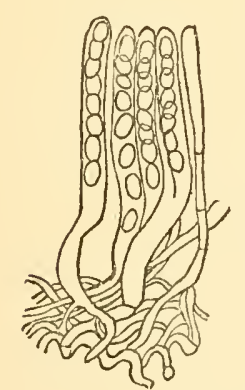
and causes them to die in great numbers. The plant of these fungi is cobwebby, sometimes growing within the cells of the plant substance on which it lives, and sometimes growing both within and on the surface. A freshly moulded piece of moist bread shows the bread covered with exquisitely fine transparent threads, which constitute the plant. Litter, spore calses containing tiny black spores will be seen, which give a delSpores borne in del- icate gray tint to the plant at first, but later form icate membran- a black, repulsive mass as their numbers increase. ous sacs (magni- These plants are regarded as descendants of defied) generate alga, which lost their power of independent existence through stealing their food instead of making it for themselves.

The second class, the spore-sac fungi, produce their spores in delicate membranous sacs. The spore-sac fungi vary greatly in size, habit, and structure. Most of them are inconspicuous members of the plant world, as the yeast plant, by which our bread is raised; the fungus which caluses the peach leaves to curl and the black knots to appear on cherry and plum trees.

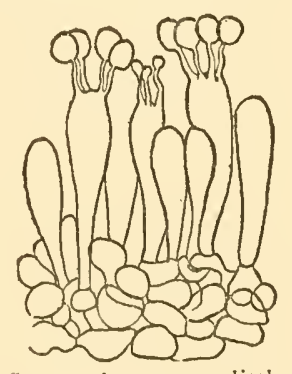

spores borne on little spicules (magnified)

The third class is made up of all fungi which bear their 
The Relation of Fungi to Other Plants

spores on little spicules standing up on large cells. This contains most of the conspicuous fungi one will care about knowing. To understand the group one must understand the method by which a spore grows to be a fungus plant, and to be able to distinguish the different members of the group one must know on just what portions of the spore receptacle the spores are borne. 


\section{CHAPTER III: FROM SPORE TO MUSHROOM}

THE way in which a spore grows into a fungus plant is very simple :

(1) The spore is a single cell, and when it is in a warm, moist place it swells.

(2) The cell absorbs food through its cell wall and divides into two cells.

(3) Each new cell absorbs food and
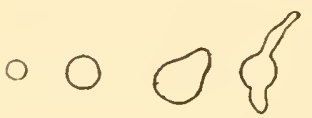
divides until long chains of cells are formed, looking to the unaided eye like threads. Each thread is a hypha, and a tangle of threads is a mycelium.

(4) In the soil the mycelium nourishes itself on decaying vegetable matter, and grows; then, at certain points, the threads mat together to form little balls the size of pinheads $(a)$.

(b) The pinheads grow to the size
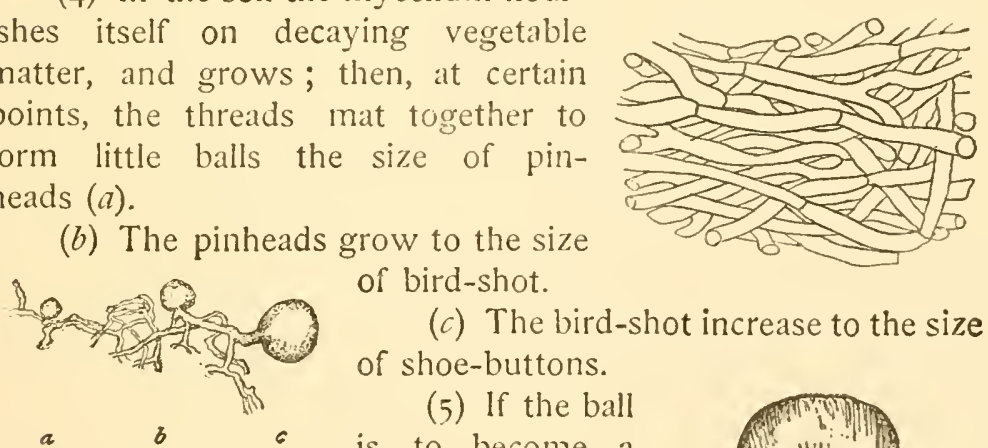

of bird-shot.

(c) The bird-shot increase to the size of shoe-buttons.

(5) If the ball is to become a stemmed toadstool, a minute stem appears on the button. The stem and button increase in size. The button is lifted above the soil and expands into a mushroom.

(6) If the button is to become a puffball, no stem appears on the button; but

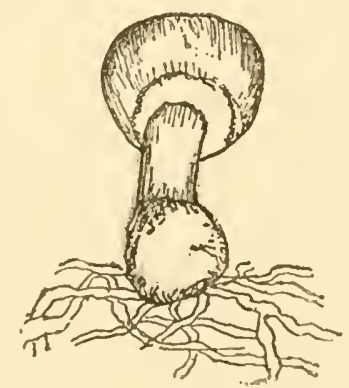


it grows, and comes out of the ground a round puffball. (See Plite opposite p. 124.)

If one wishes to learn to distinguish the members of the

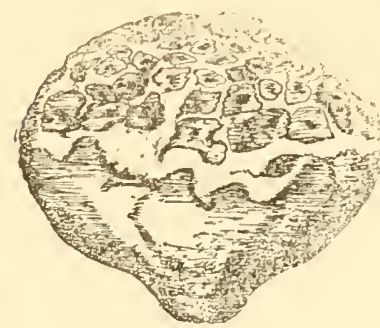

Puffball mushroom or toadstool family, either for the pleasure he may derive from knowing them, or from a desire to distinguish the edible from the poisonous, he must be familiar witi the typical parts of the fungus plant, and must

know the names of these parts.

The edible mushroom of the market

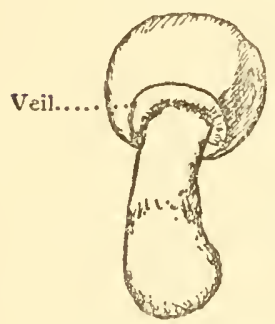
(Agaricus campesiris) serves well for study, as it shows some of the characteristics which all the toadstools, mushrooms, brackets, and puffbal!s have in common.

(1) This mushroom is in shape something like a parasol.

(2) The handle is the stem, or stipe.

(3) The open top is the cap, or pileus.

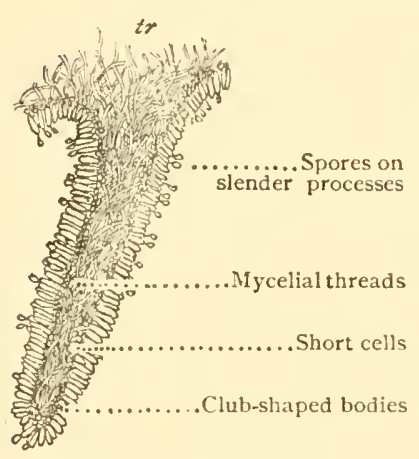

Section across gill (magnified)

(4) Under the cap, radiating from the stalk to the edge of the cap, are
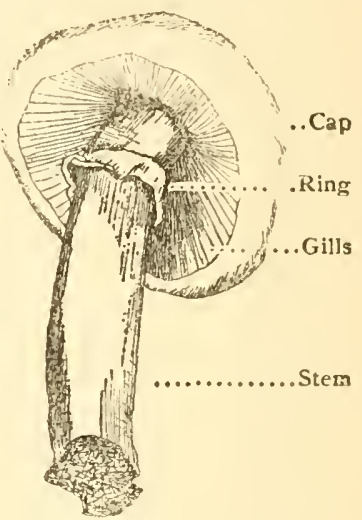
tem thin plates-the gills, or lamellx.

(5) When the mushroom is in the button stinge, the gills are not visible, for they are covered with a thin sheet of mycelial threads, called the veil. (See coloured plate of Agarious campestris.)

(6) As the button grows the veil stretches, and finally breaks, 
leaving a ragged edge to the cap, and a ring or annulus of veil around the stem. The gills of the Agaricus are not fastened to the stem, but are rounded off at the end near the stem, while others, between the long ones, extend from the edge of the cap only far enough toward the stem to fill up the angles formed by the long gills.

The surface of the gills is the fruiting portion of the mushroom. It is here that the spores are formed.

The structure of the fungus plant up to this point has been similar throughout. A loose tangle

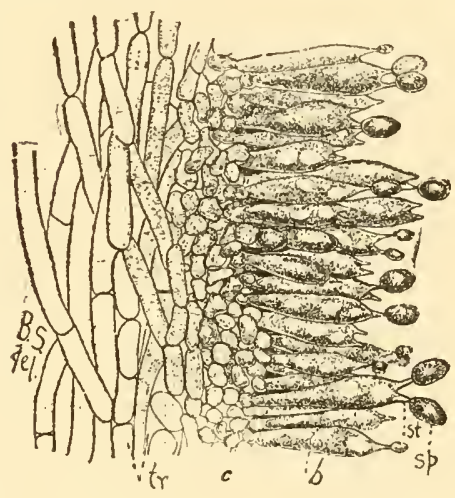

A small portion of section of gill (highly magnified)

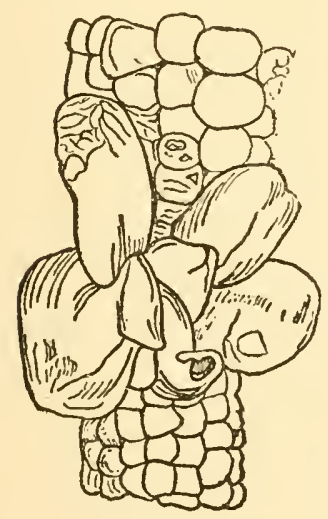

Corn smut

of threads underground formed the mycelium-the food provider. A more closely matted tangle above ground formed the stem and cap and veil, and even the central part of the gill-the fruiting parts of the plant.

On the surface of the gill a difference in structure is found, which will be clearly understood from a picture of a thin section cut across a gill.

(1) The central portion of the gill is made by loosely tangled mycelium threads $(t r)$ draping themselves in thin plates from the surface of the cap.

(2) Just outside of this loose mycelium, on either side, are layers of short cells $(c)$, which bear clubshaped bodies standing out over both surfaces of the gills (b).

(3) Each club bears two slender processes $(s t)$ at the free end, and each process bears a spore $(s p)$.

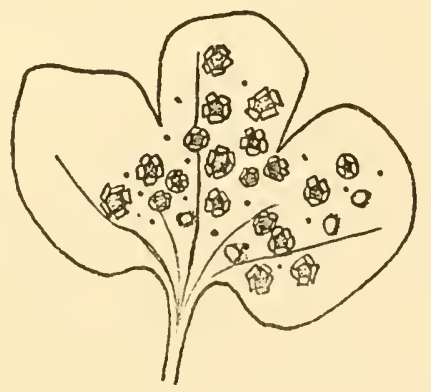

1.eaf rust on Hepatica triboba 
All corn smuts, wheat smuts, leaf rusts, toadstools, puffballs, and brackets bear their spores on club-like cells, and for

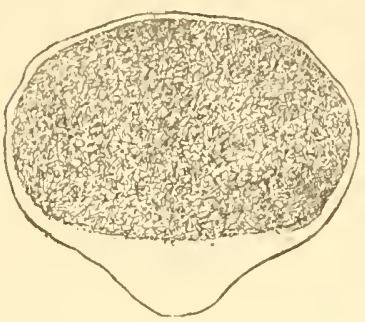

Pouch-fungus section, to show spores in hollow rind this reason are put in one group, called Basidiomycetes.

The fact that corn smuts and leaf rusts feed on living plants, while toadstools, brackets, and puffballs feed on dead plants, separates them into two groups; the smuts and rustsforming the lower group,

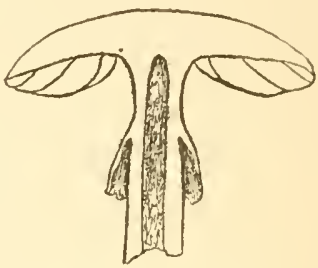

Section to show gills and the others the higher group. It is the higher Basidiomycetes which we wish to consider, as this group includes most of the conspicuous fungi, most of the eai-

Section of a Boleius, to show pores ble, and those fungi which are dangerous because of their resemblance to edible species.

Remembering that toadstools, puffballs, and brackets all start from spores; that all have the

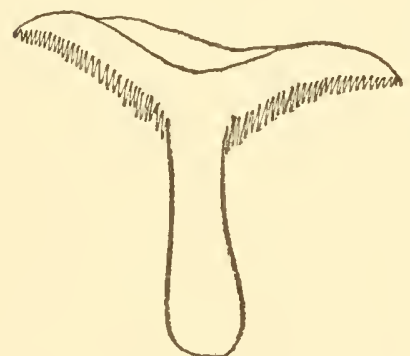

Section of Ilydnum, to show teeth tangled thread-like plants, seeking the dark; that they all have the spore receptacle in the light, and

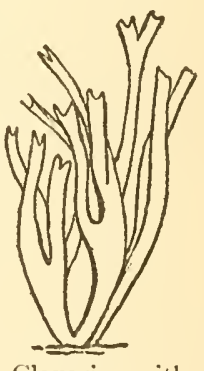

Clavaria with spores on spines bear their spores on club-like cells, one can readily understand their being put in one group.

With a few exceptions not necessary for us to consider, all the higher fungi naturally divide into two groups-pouch-fungi (Gasteromycetes), which conceal their spores in a definite rind, or peridium, as the puffballs do; and membrane fungi (Hymenomycetes), now called Agaricales, which bear their spores exposed on the surface of gills, pores, spines, or teeth, as the garden mushrooms, the Boleti, the Clavarias, and the Hydnums. 


\section{CHAPTER IV : THE KEY}

WHAT A KEY IS, AND WHY A NAME IS DESIRABLE

A KEY in the study of botany is a guide by which a student may trace a specimen until he finds a name for it. Having found a name, he may learn from books or from friends what is known of its habits of growth, of its value as a food or drug, whether it is harmful or harmless, whether it is to be protected or whether war is to be waged against it. He may learn whether it has figured in history or the myths, and how the poets and artists viewed it, and may perhaps learn to see it with their eyes. He may watch similar specimens as they grow, and may add the results of his observations to the facts already recorded about his specimen.

HOW A KEY FOR FUNGI IS MADE, AND WHY IT IS DESIRABLE

In the first place, only such plants are considered as grow from spores and have no leaf-green. (The spore characteristic is one the amateur must decide upon either by seeing the spores or by inferring their existence from the fact that seeds do not appear.) There are some thirty-five thousand species of fungi known to botanists, so that it would be impossible to find a name for a specimen if one had to read at random until the right description for his specimen was found; but since all of these plants may be put in one or another of three groups, on account of certain points of resemblance which they have in common, and since these three groups may each in turn be divided and subdivided, one may, by selecting groups rather than individual specimens, find a short path to the name desired. The three primary groups, called classes, are made as follows :

The first contains many mould-like fungi which resembl one another in microscopic characters.

The second contains other mould-like fungi and many con 
spicuous fungi which bear their spores in transparent sacs (see first page of Key).

The third contains all fungi which bear their spores on enlarged cells called basidia (see first page of Key).

To even partially understand the inconspicuous fungi is a task impossible to one who is not familiar with the use of a compound microscope. To acquire a knowledge sufficiently accurate to identify nearly all of the conspicuous fungi is within the power of any intelligent person, for the two groups or classes containing the conspicuous species may be divided, on account of easily distinguished characters, into groups called orders. The orders may be divided into groups called families, and the families into groups called genera (singular genus), and the genera into individual specimens called species; and all these groups may be arranged in such il waly that the series of selections may be quickly made. Such an arrangement of groups is called a key. 


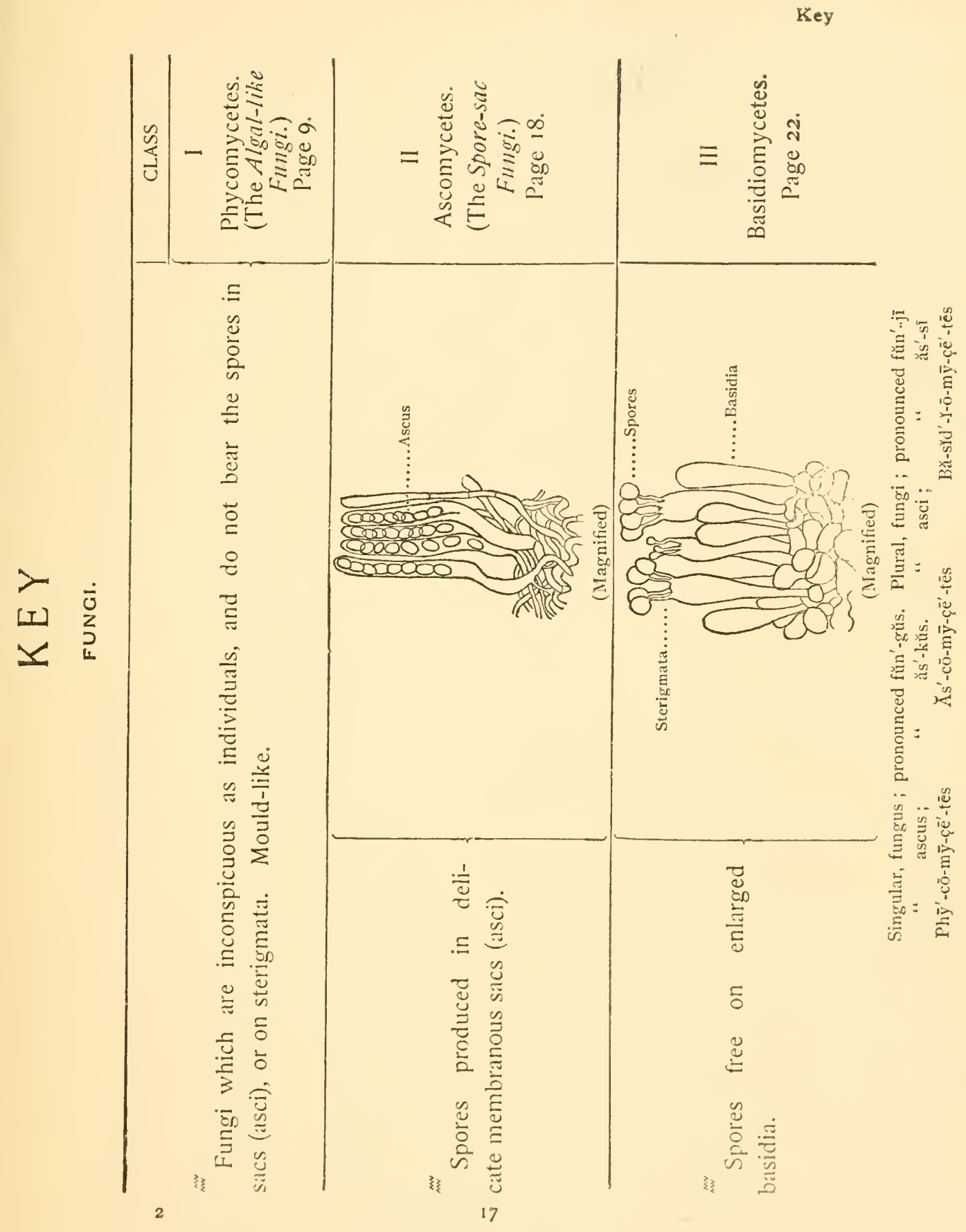


Key

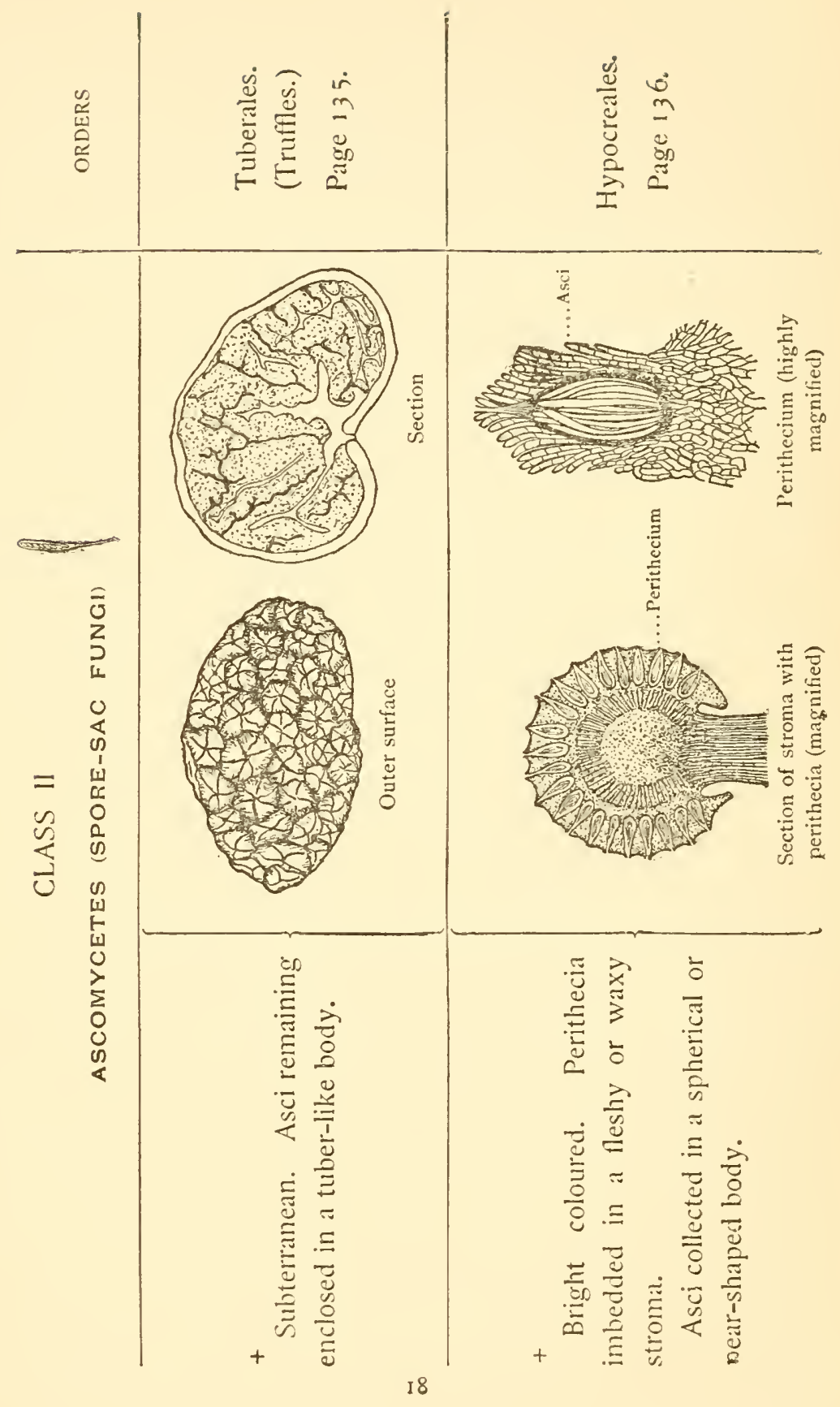


Key
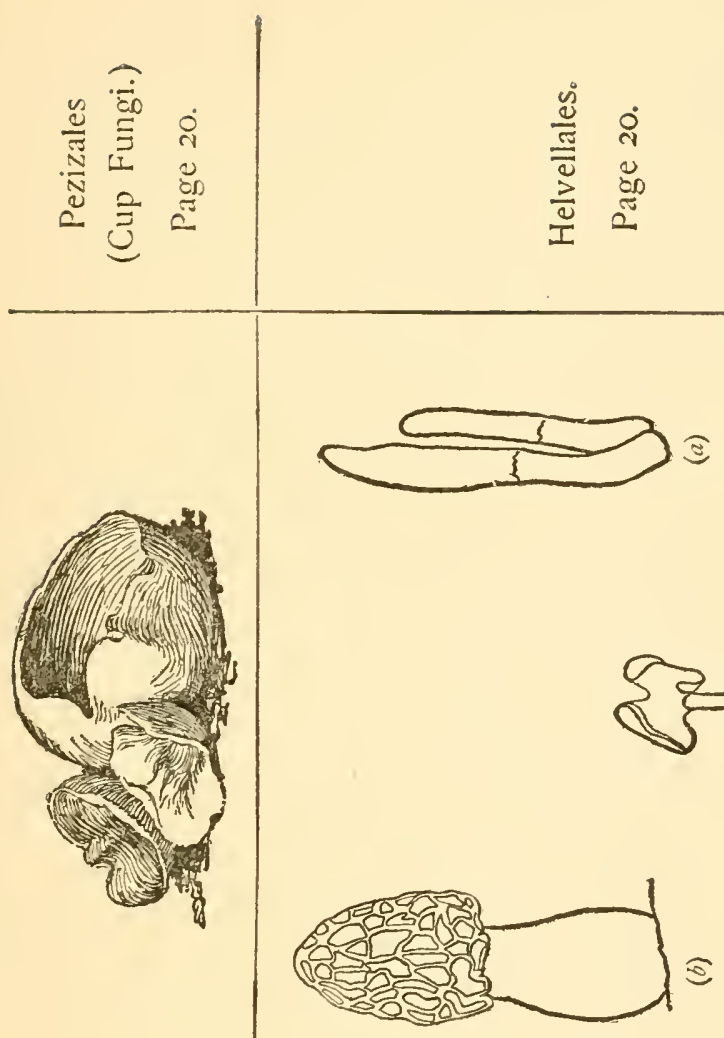

要

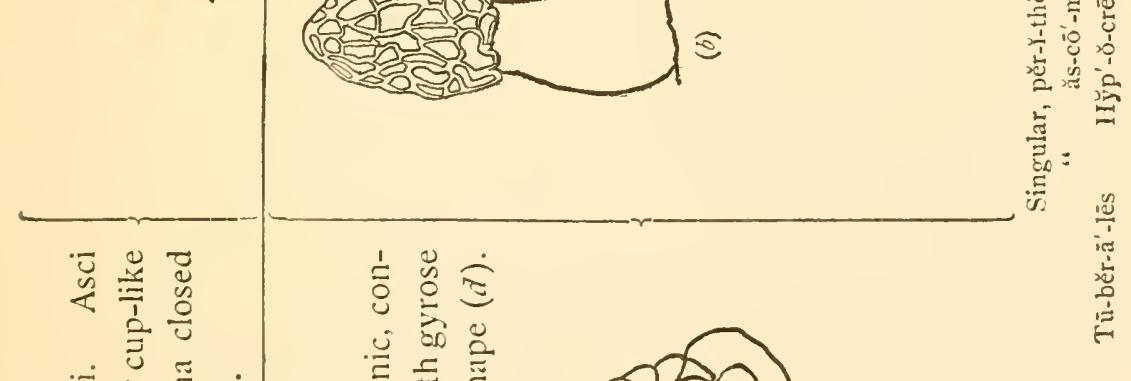

हि

๖ 竞芯

志芯芯

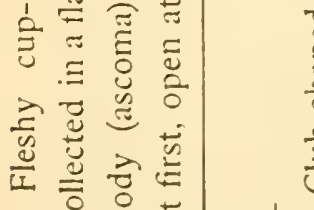

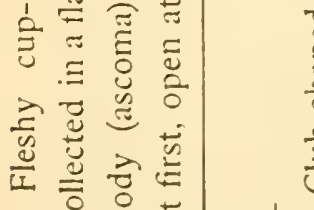

$+$

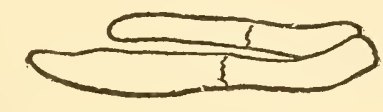

()

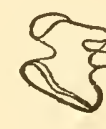

告

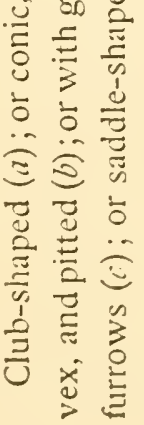

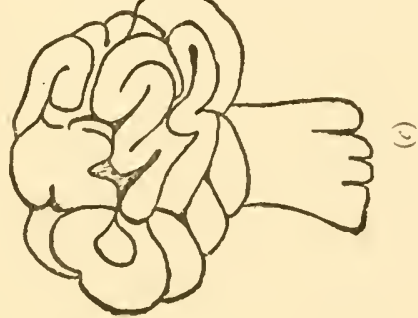


Key

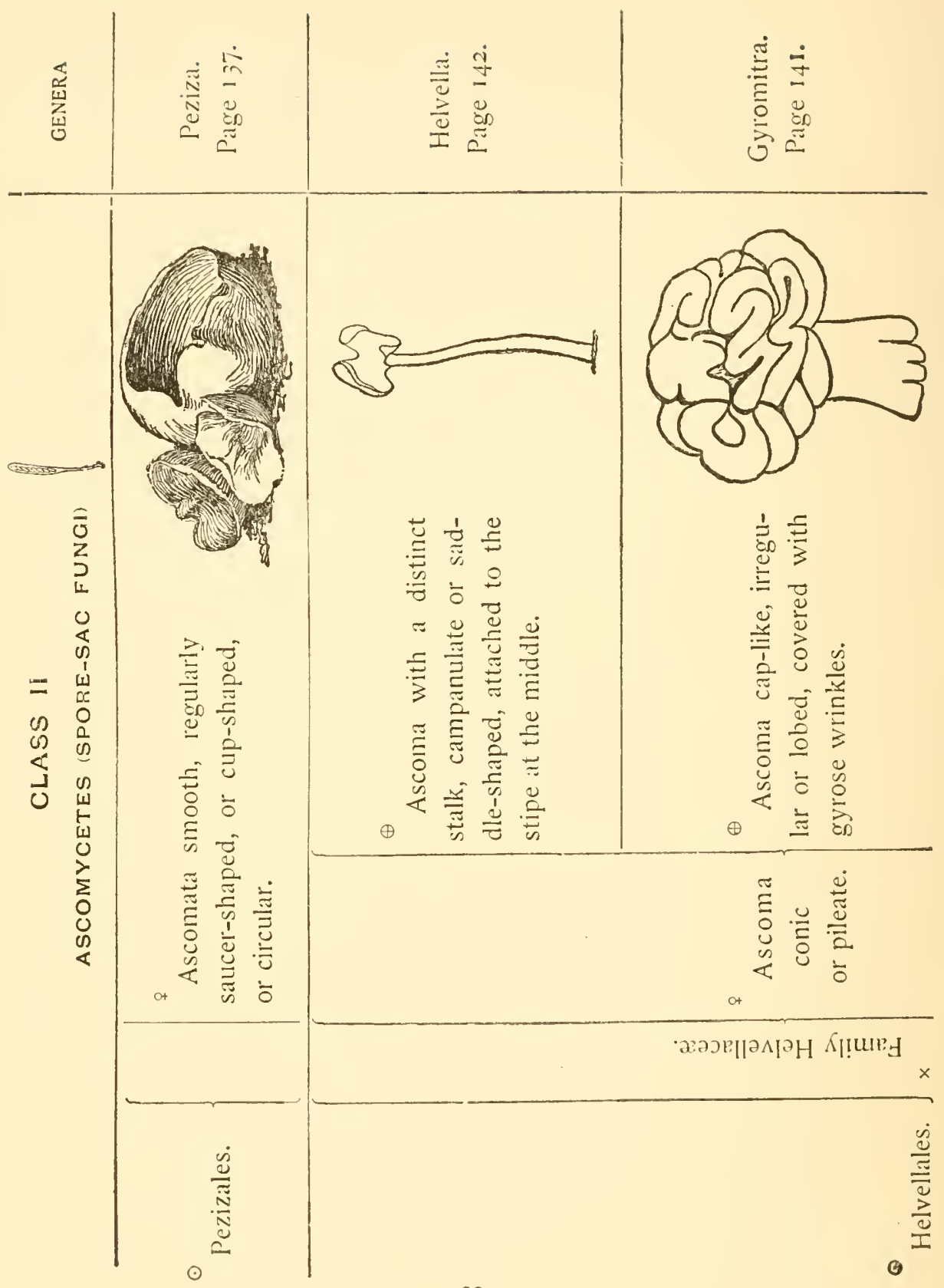


Key

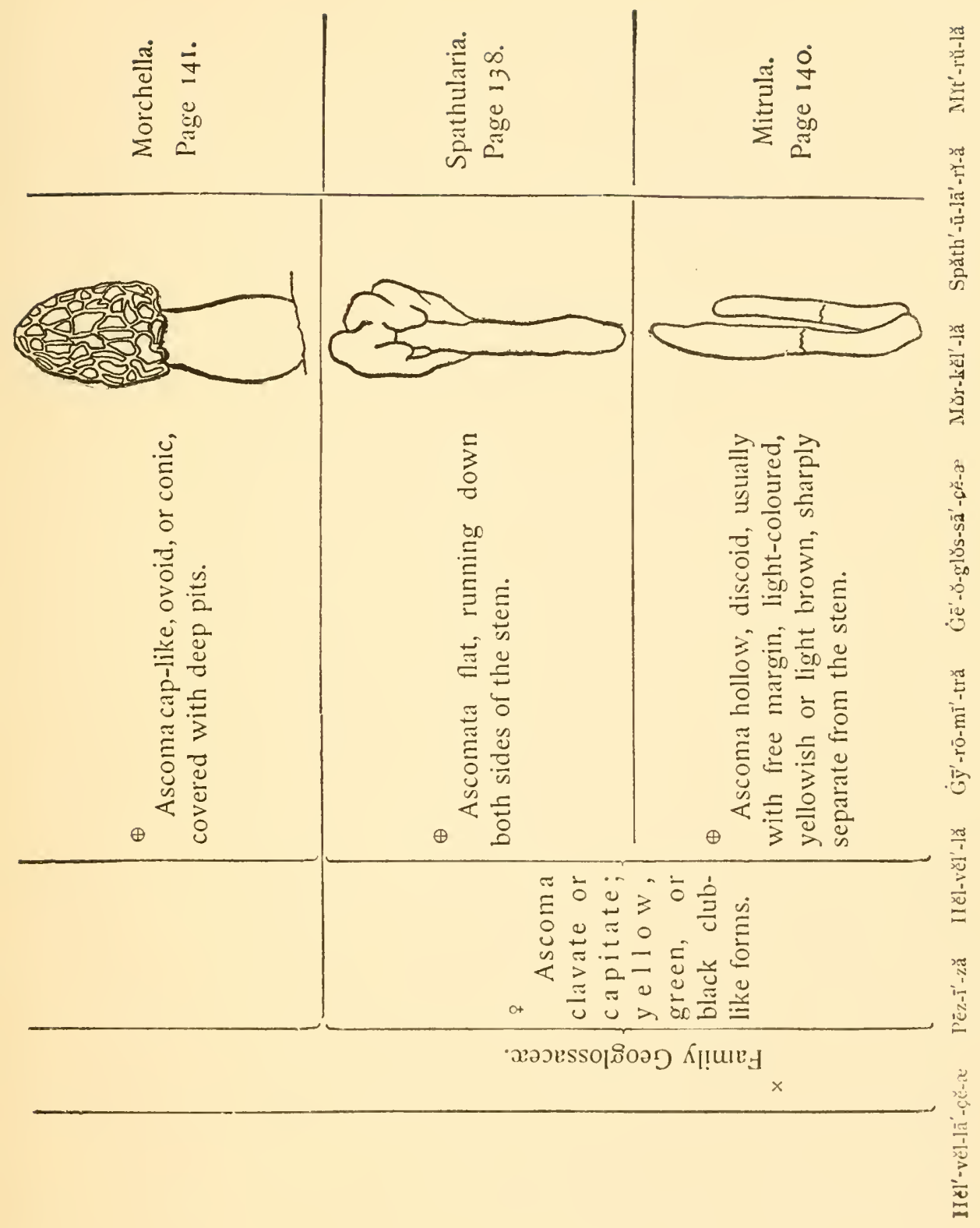


key

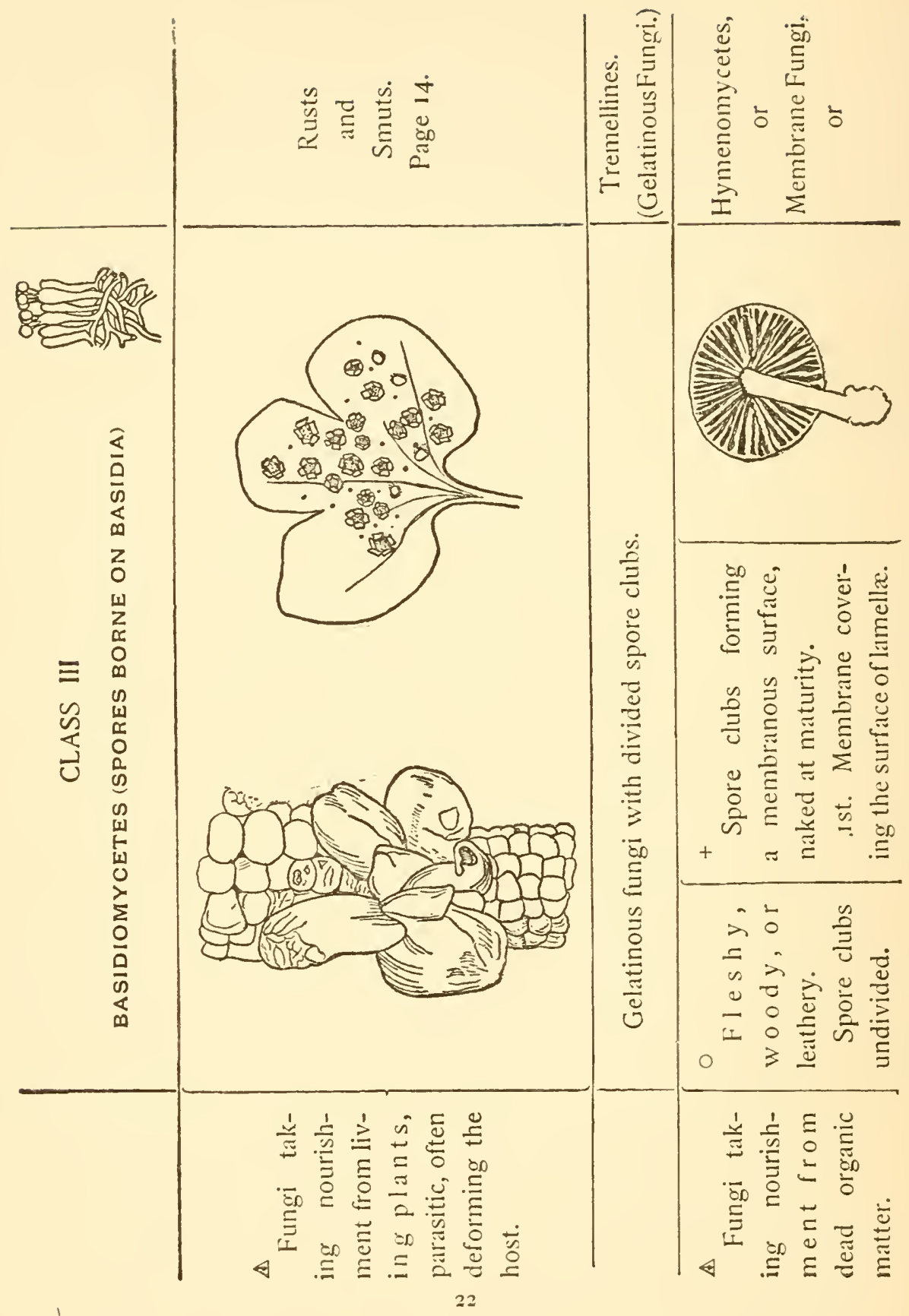


$\mathrm{Key}$

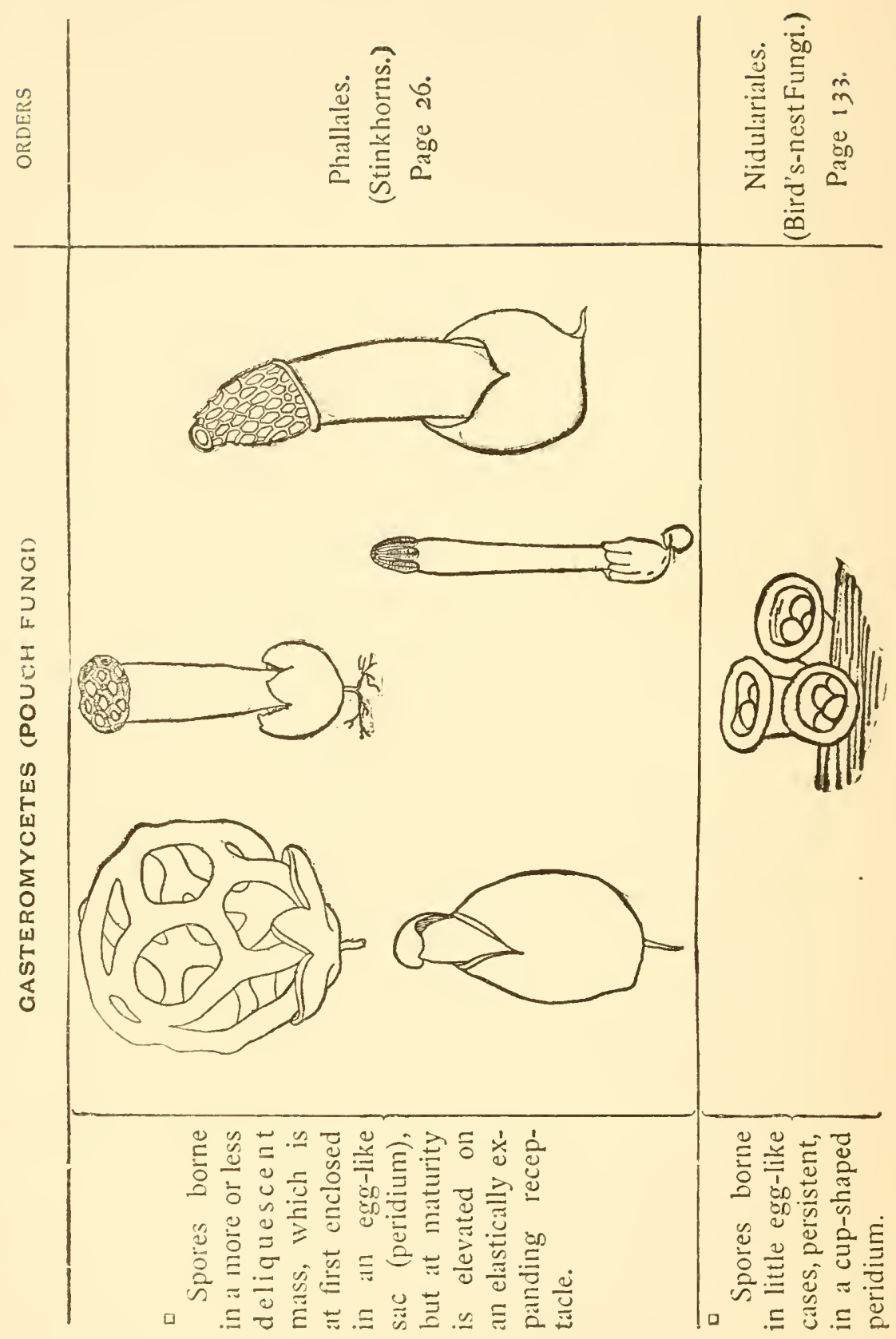




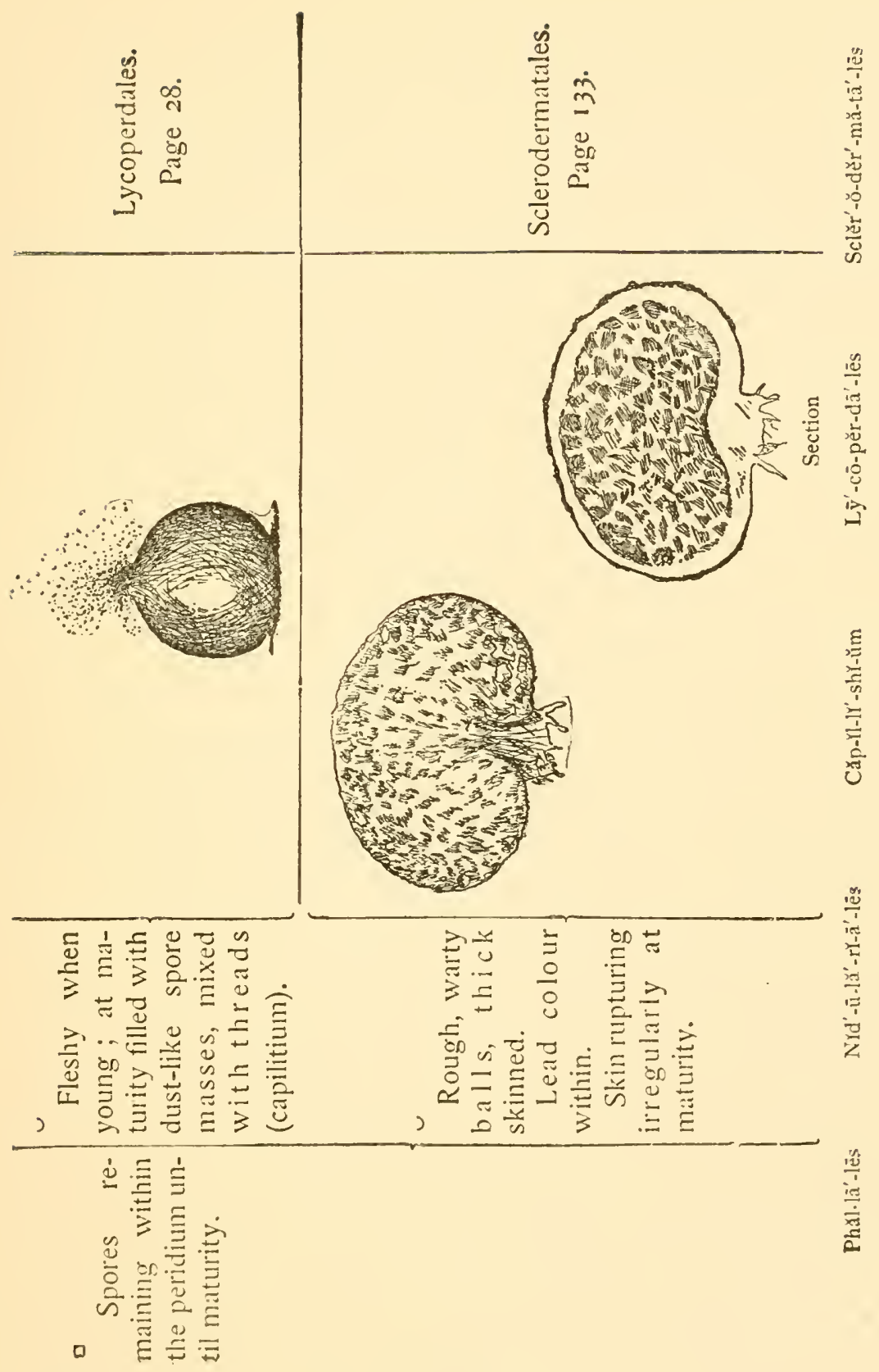


Key

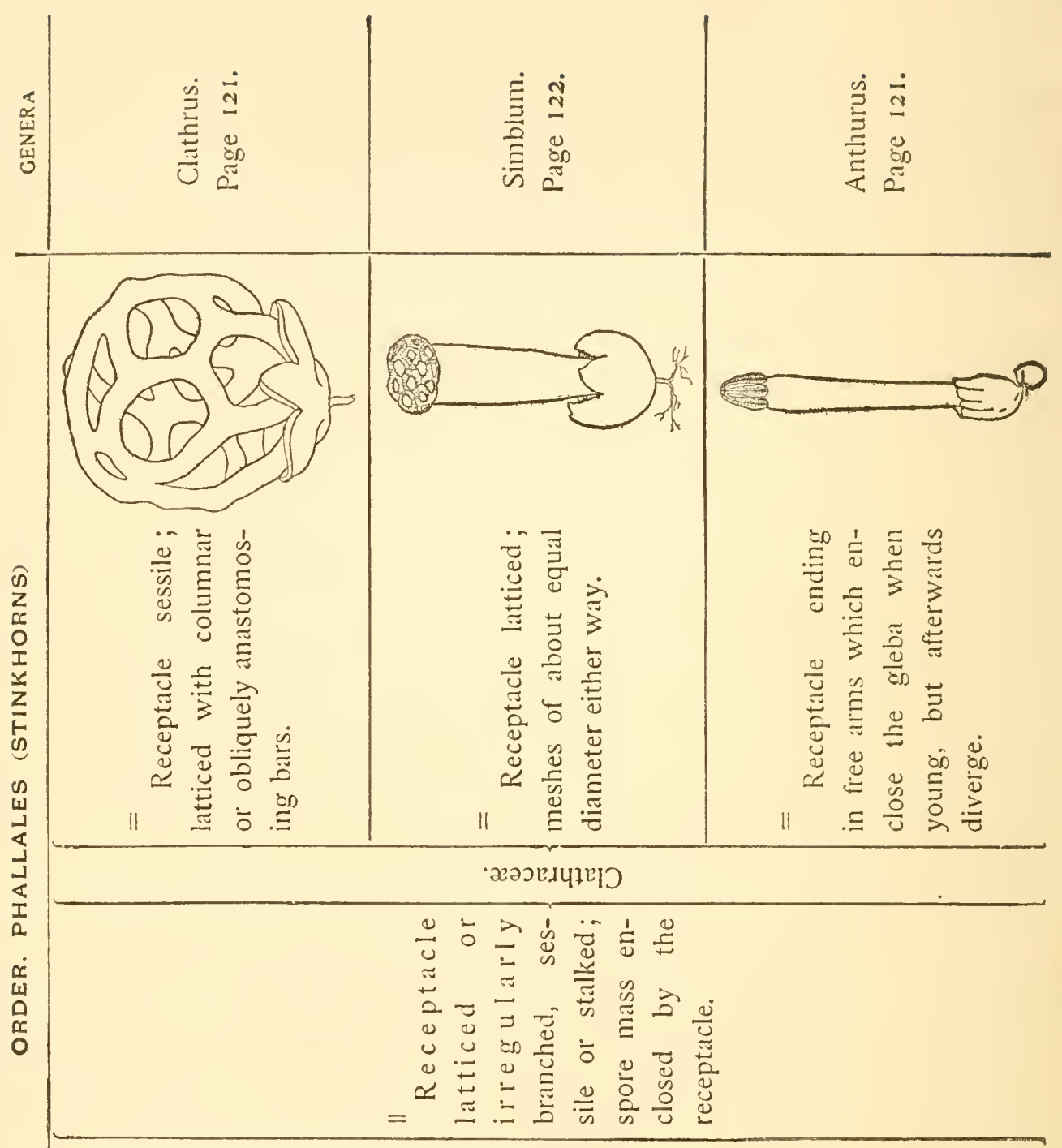

n

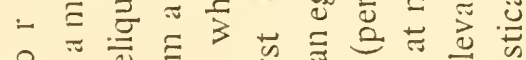

0 :

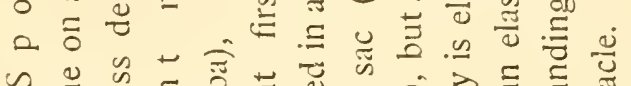

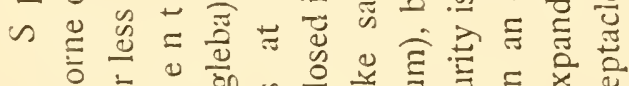

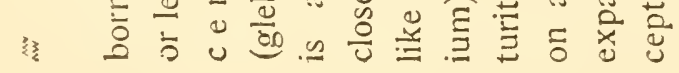


Key

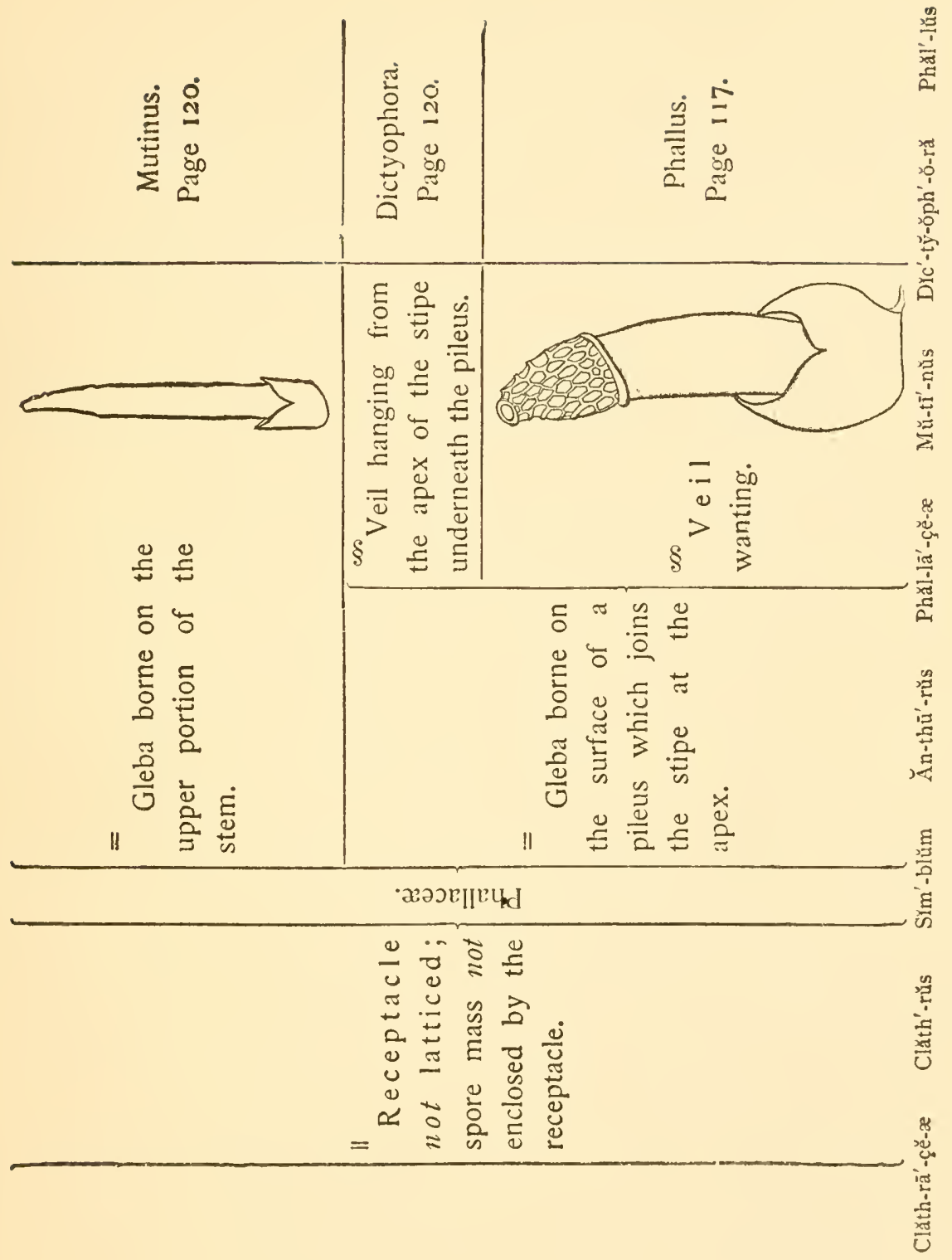

先 
Key

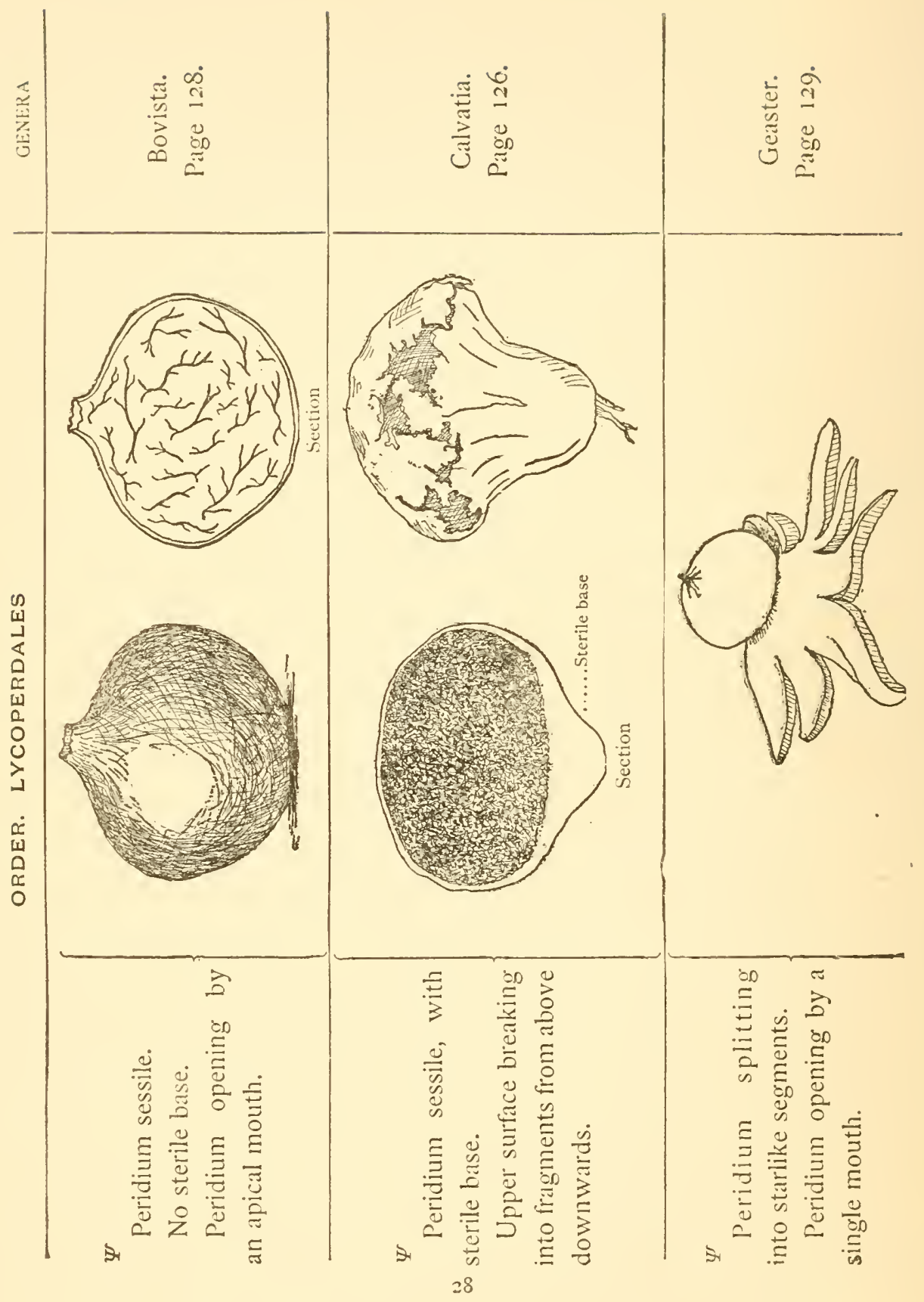


Key

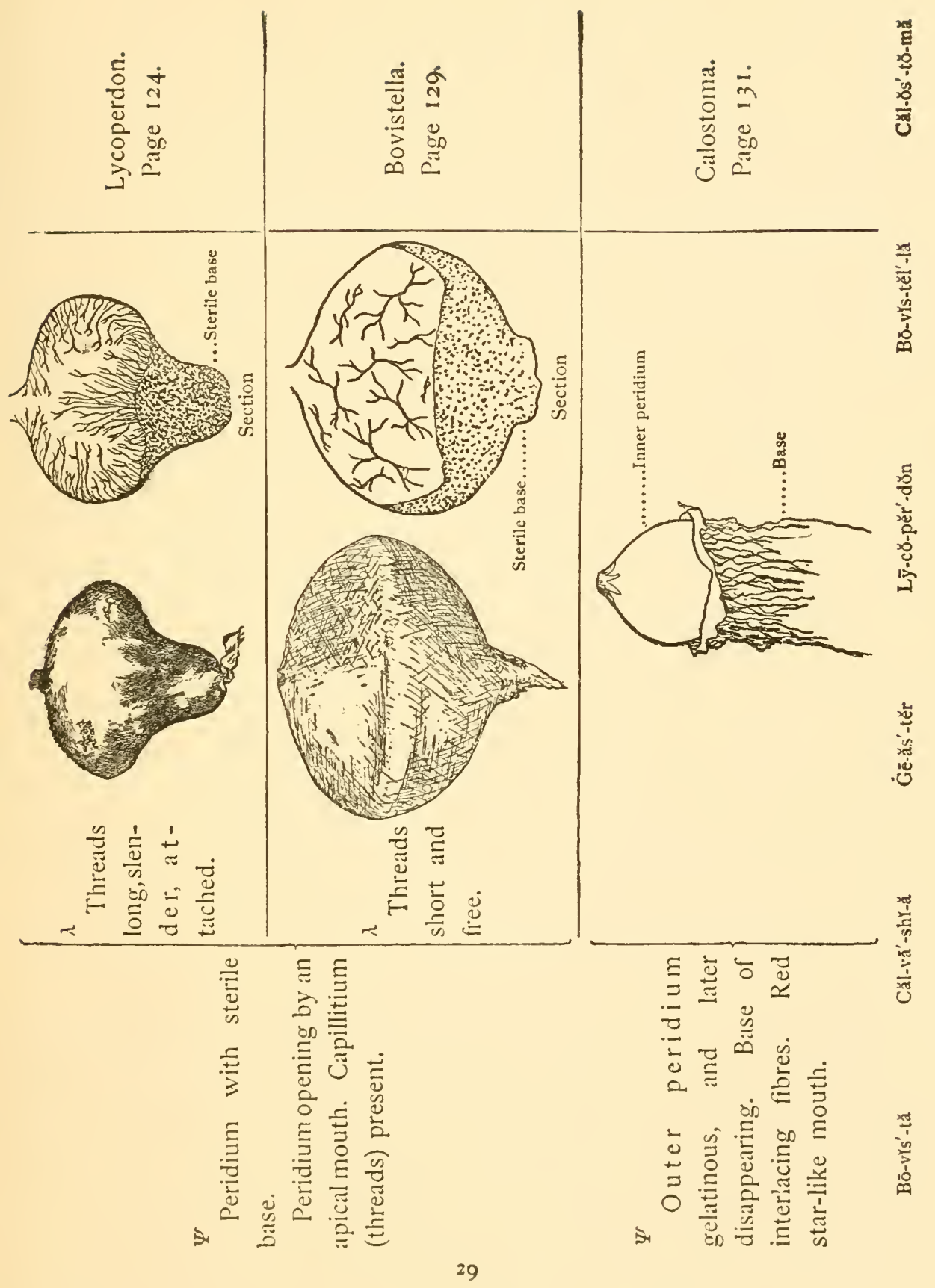




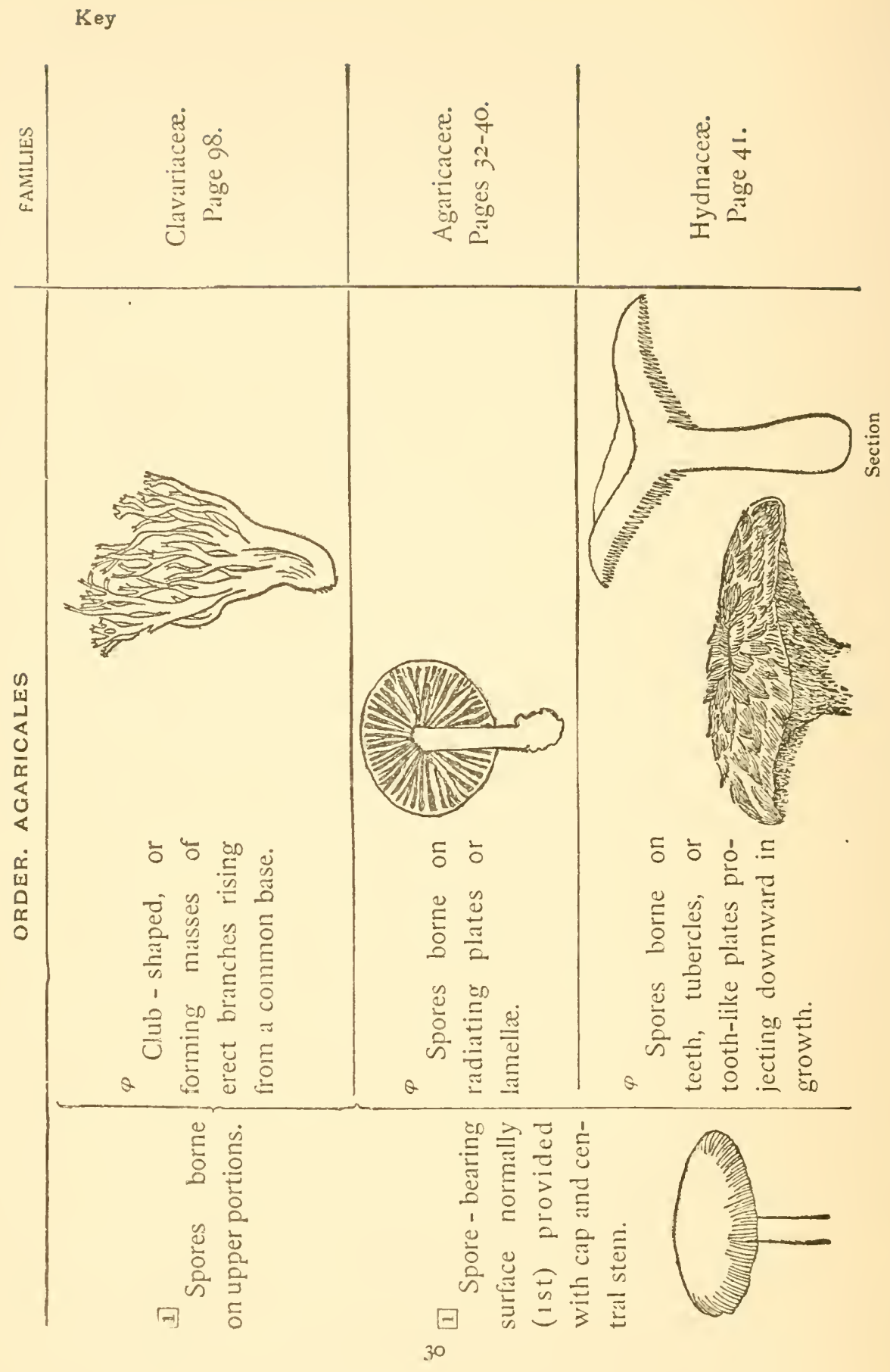


Key

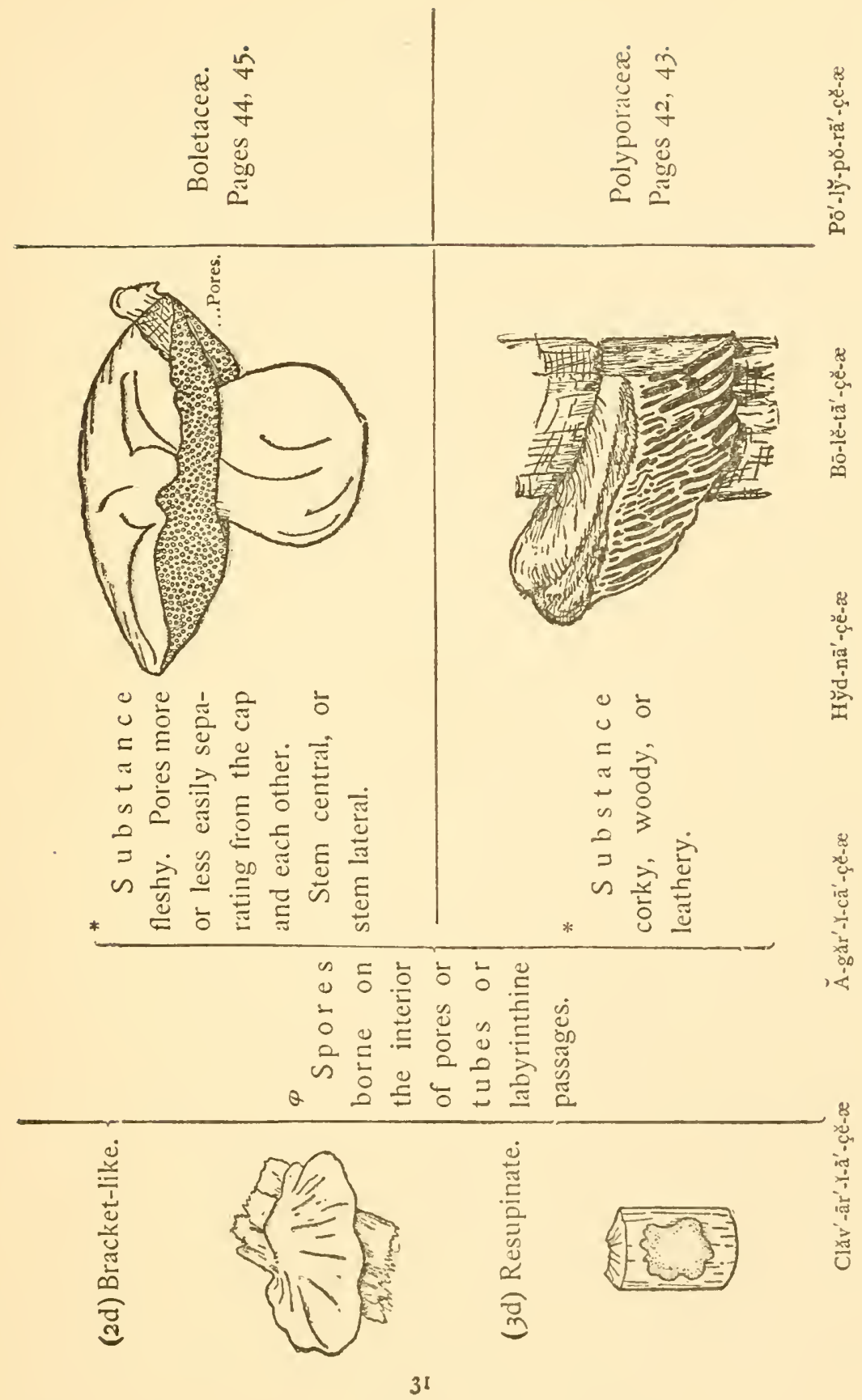




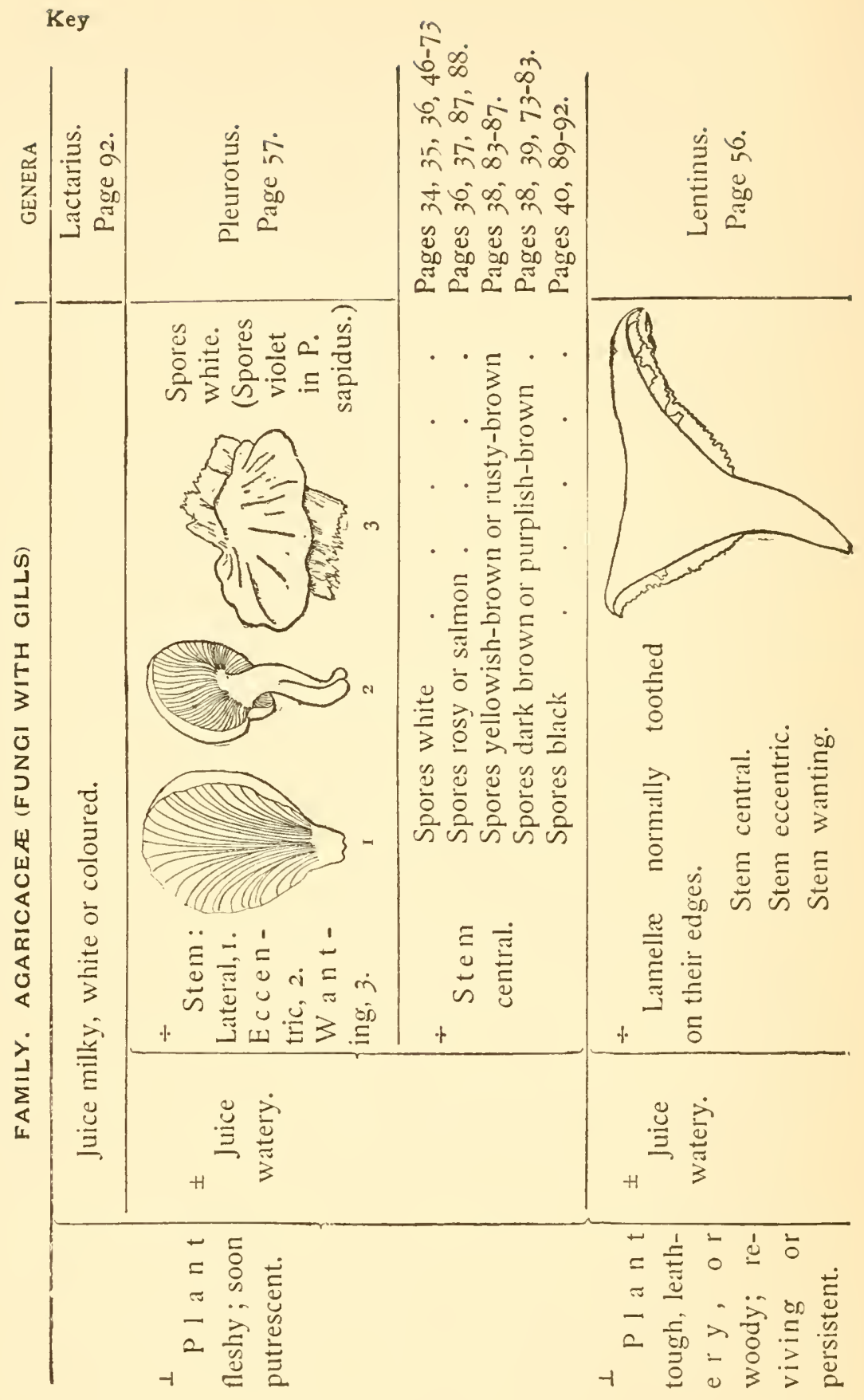


Key

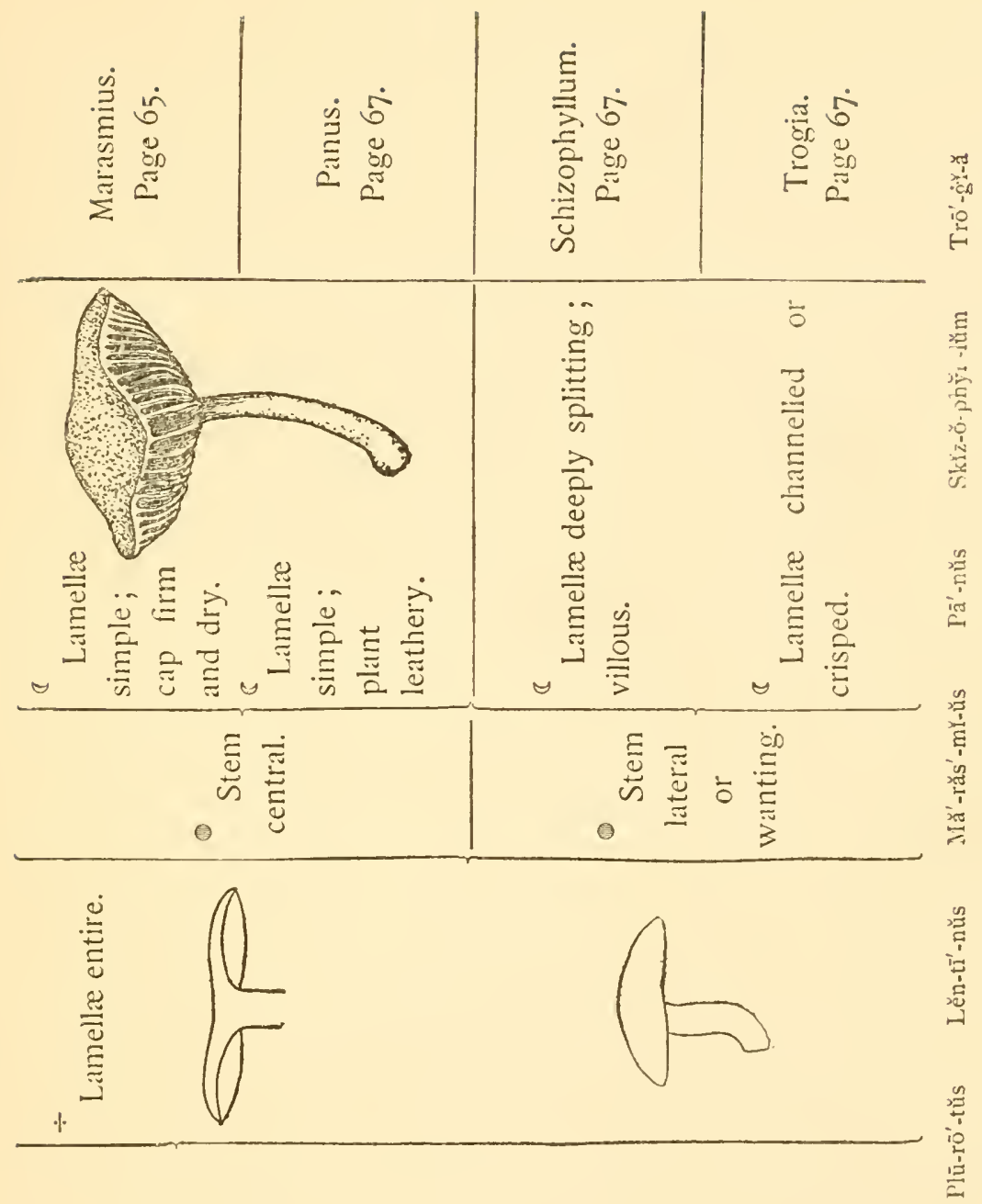




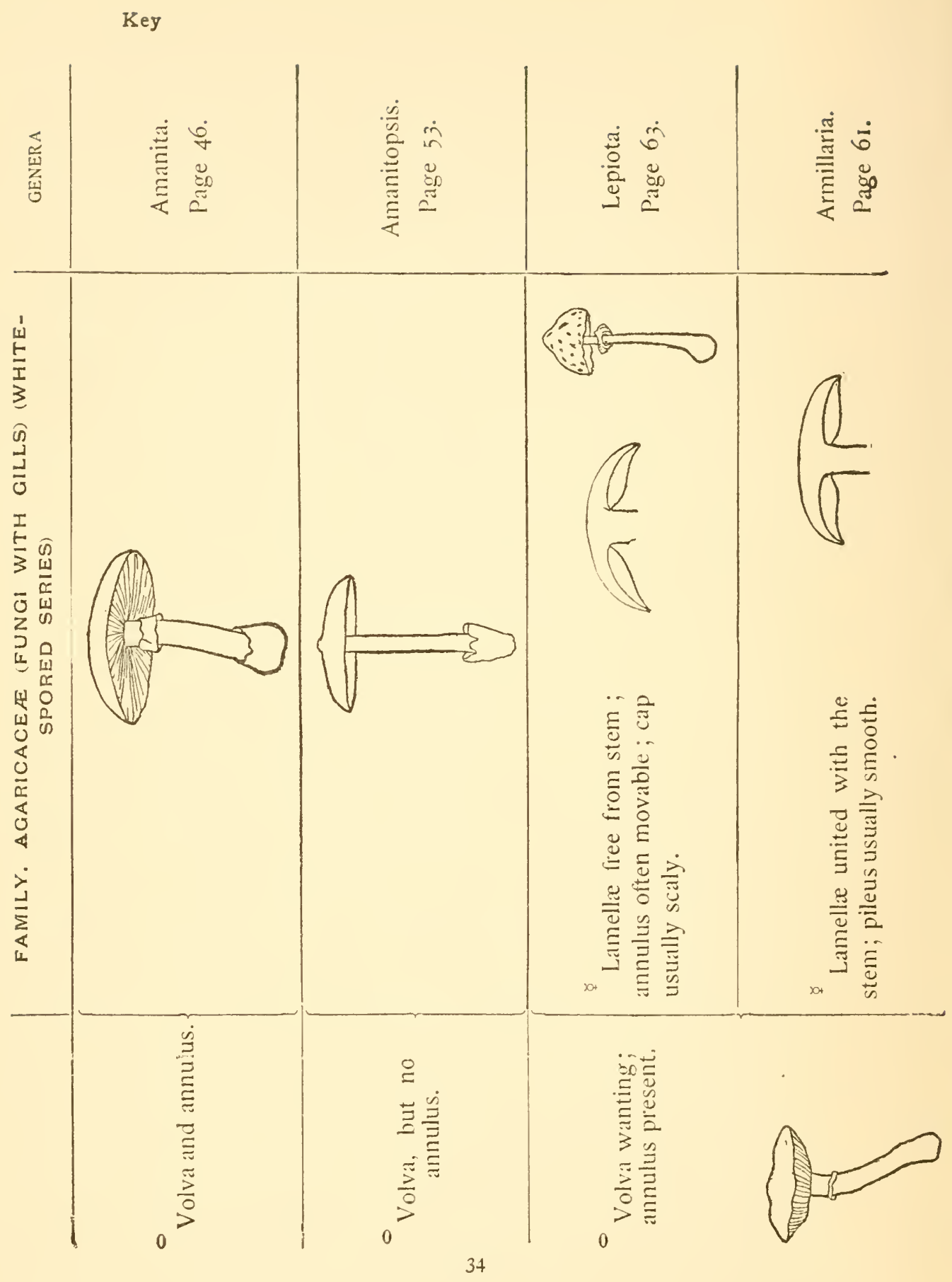


Key

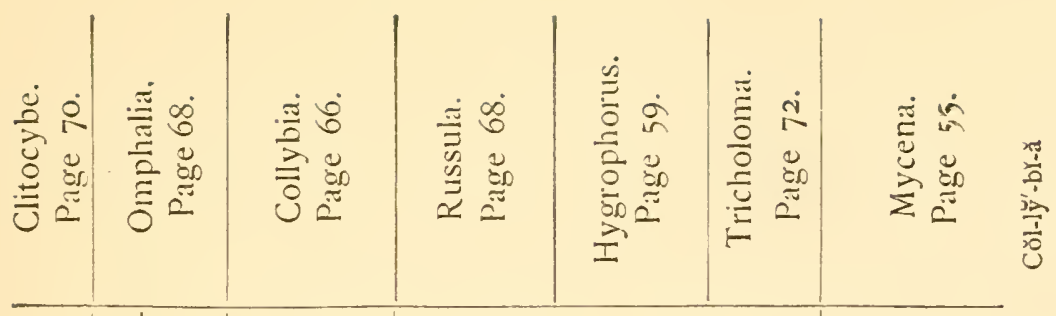

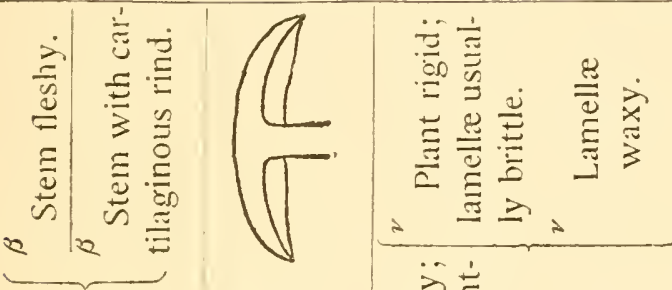

(

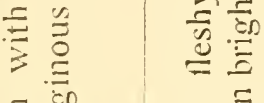

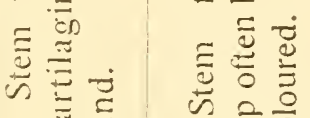

兊导

芦

总

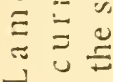

$\longrightarrow 5$

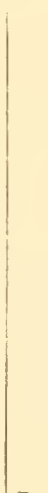

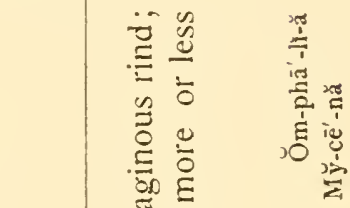
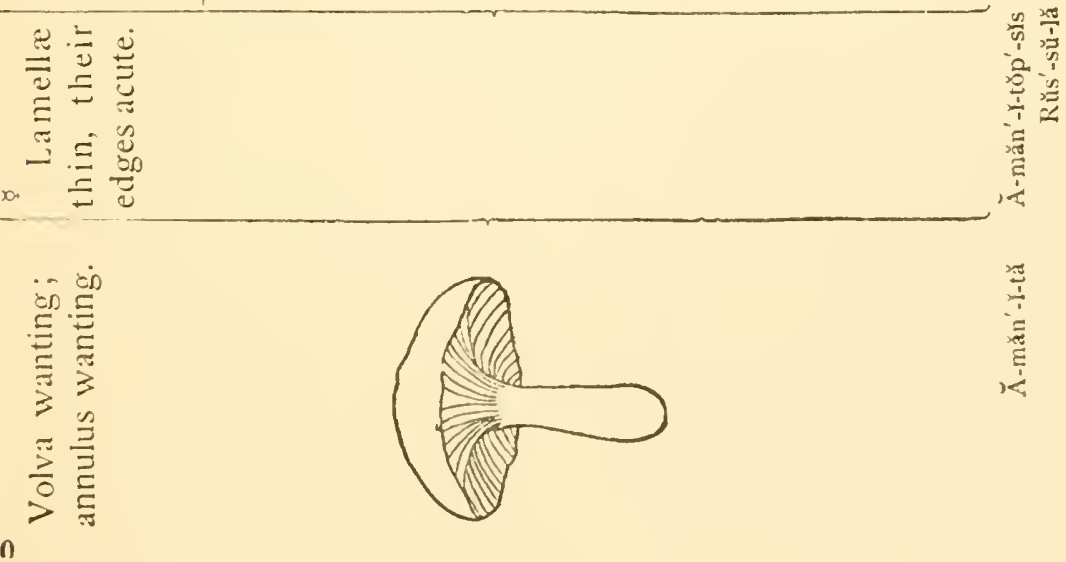

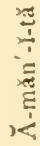


Rey

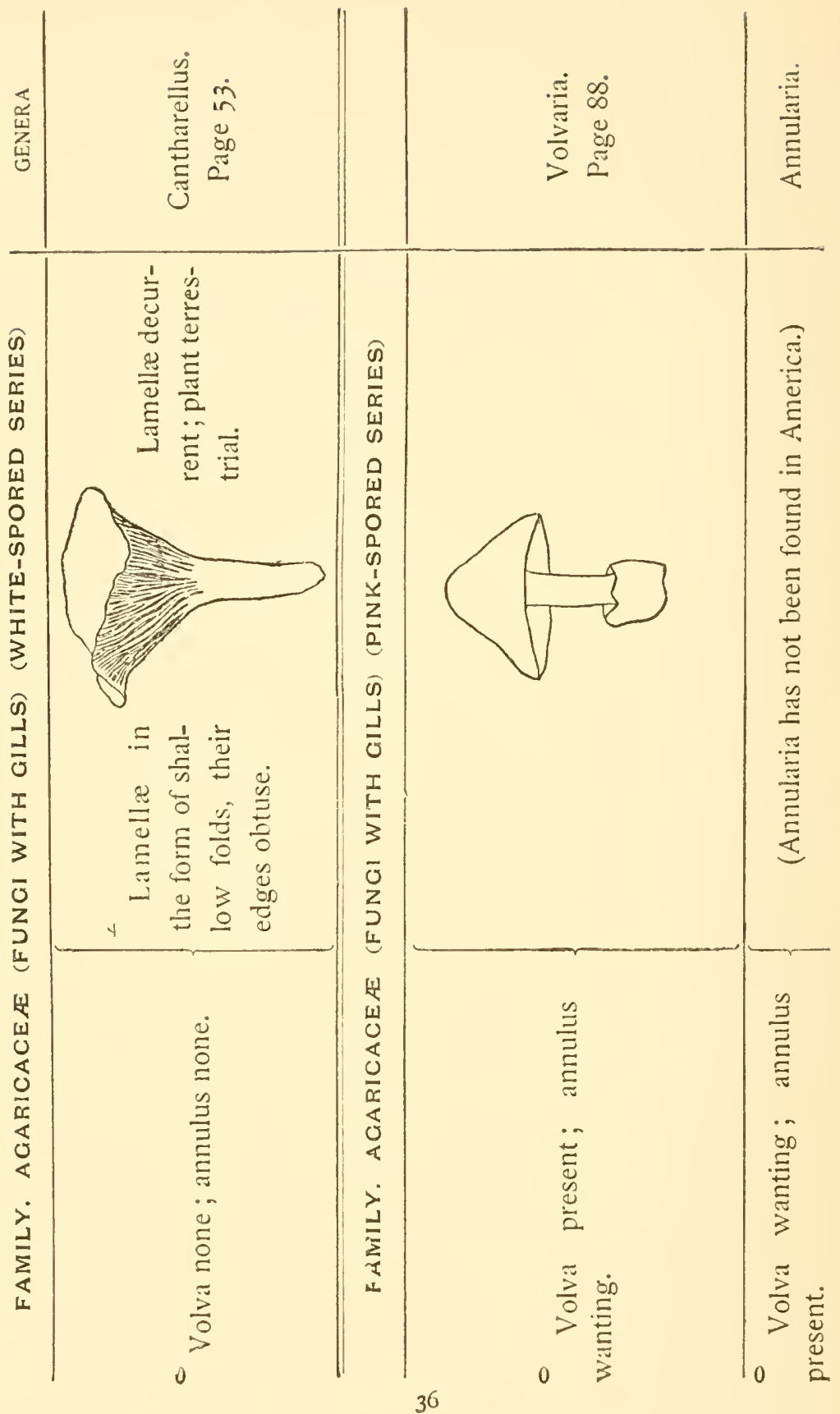


Key

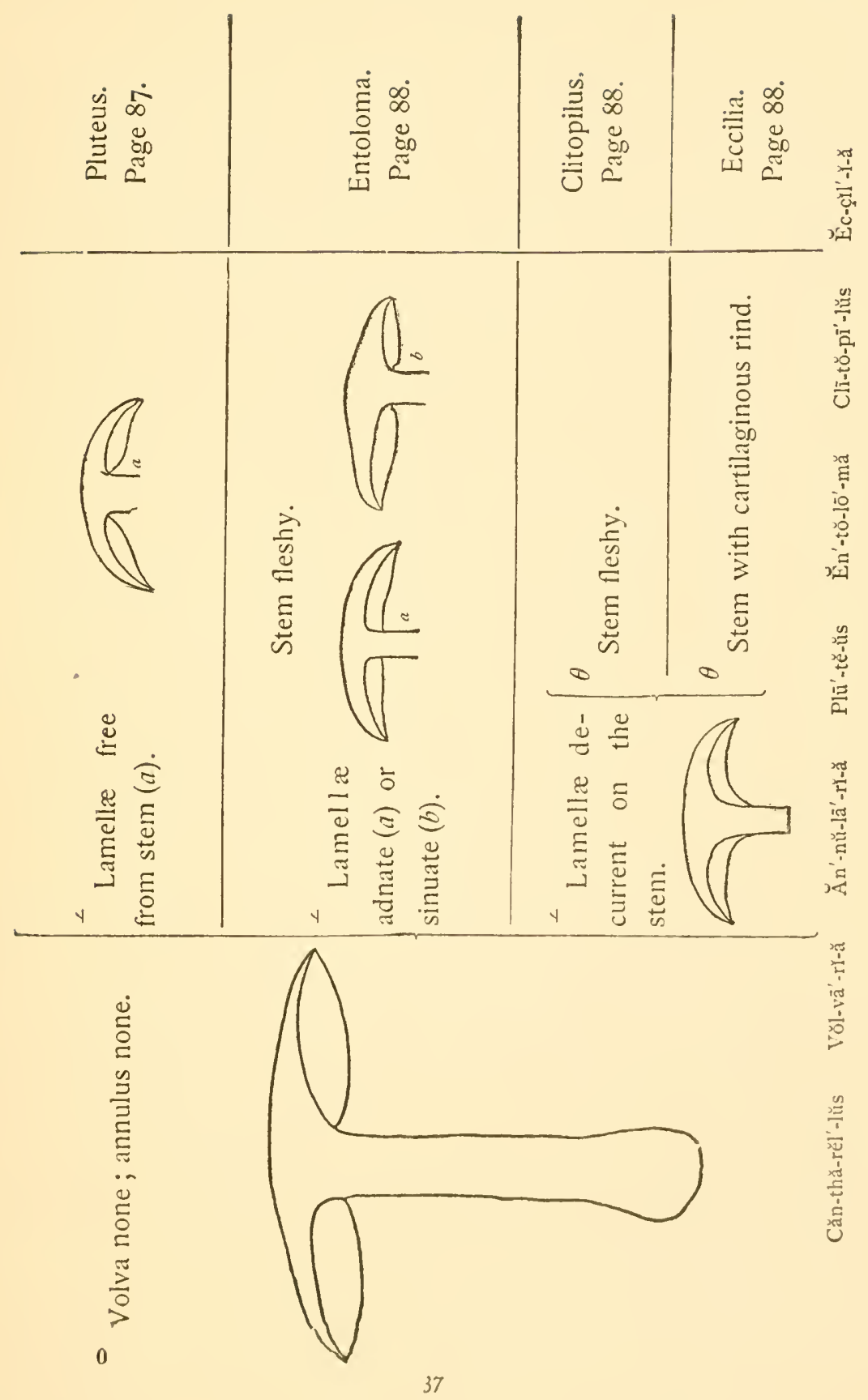


Key

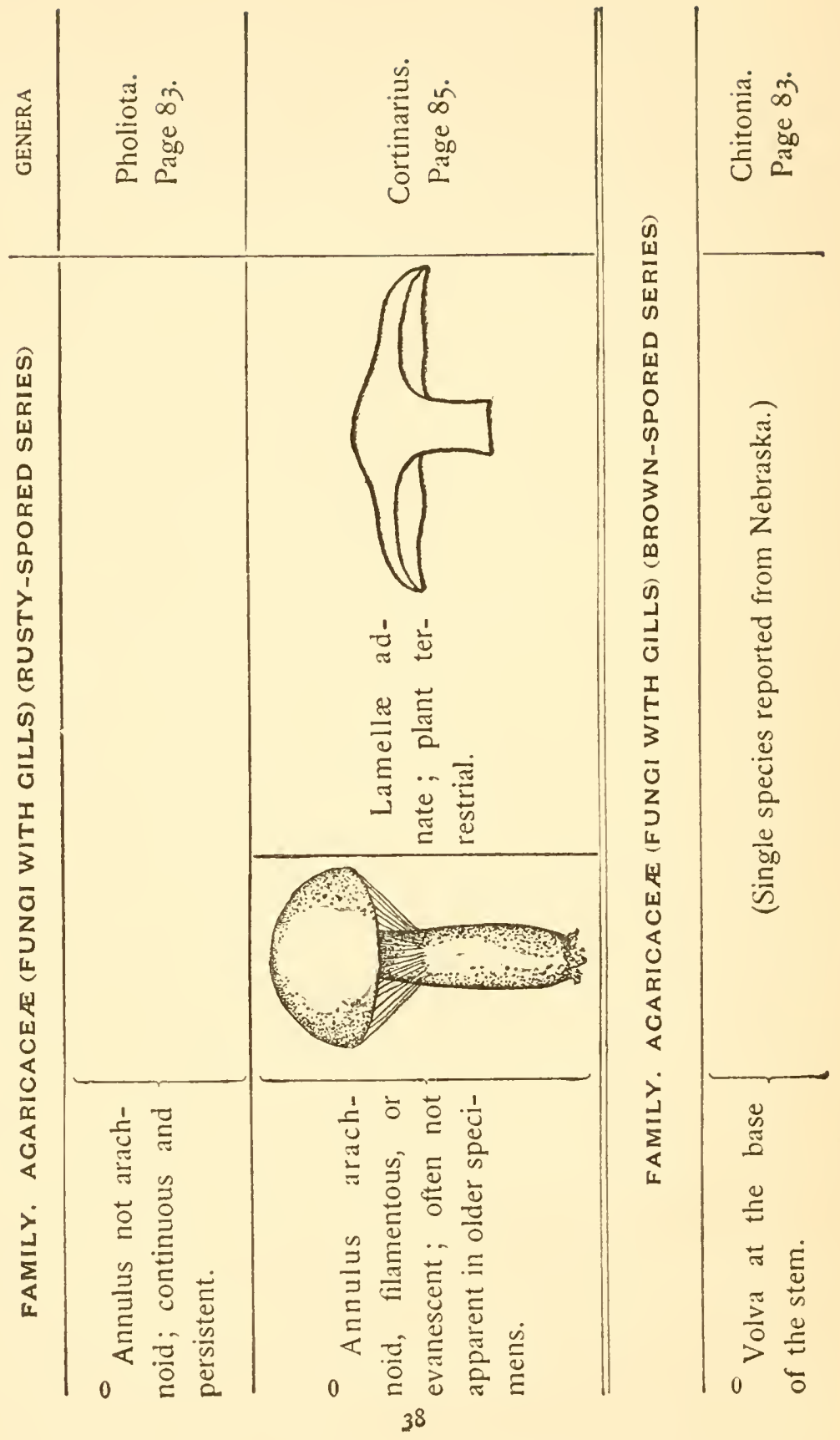




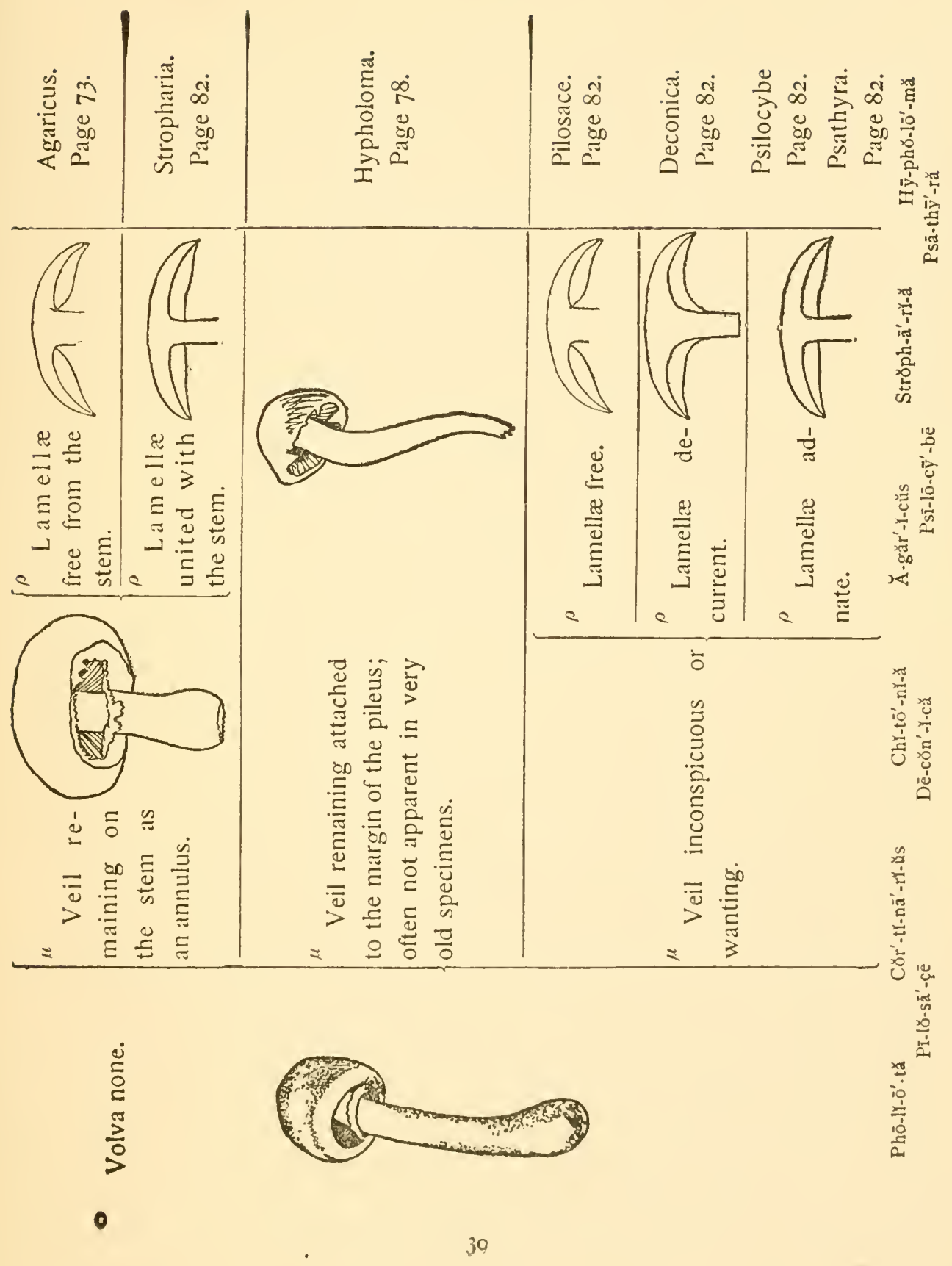


Key

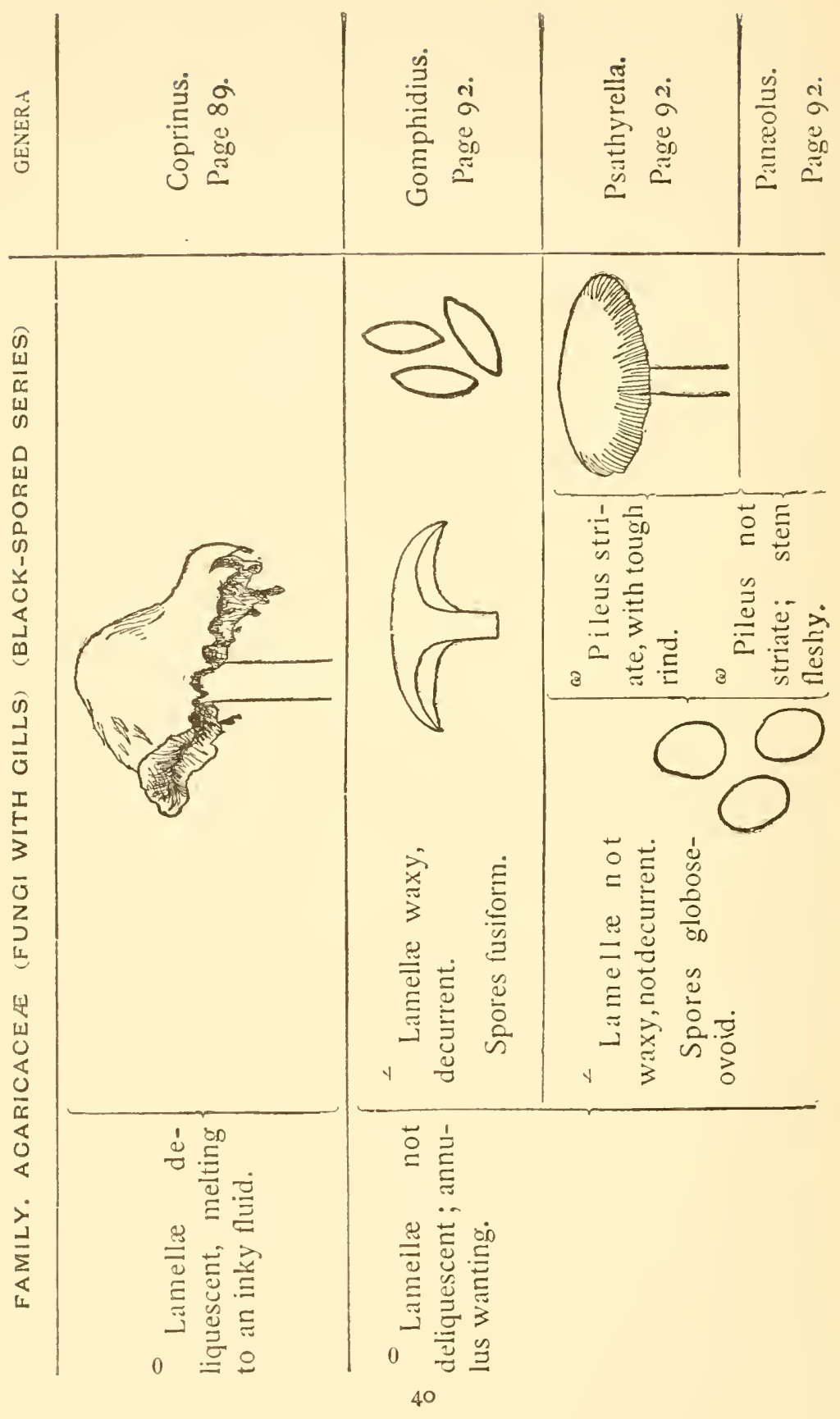




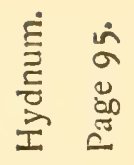

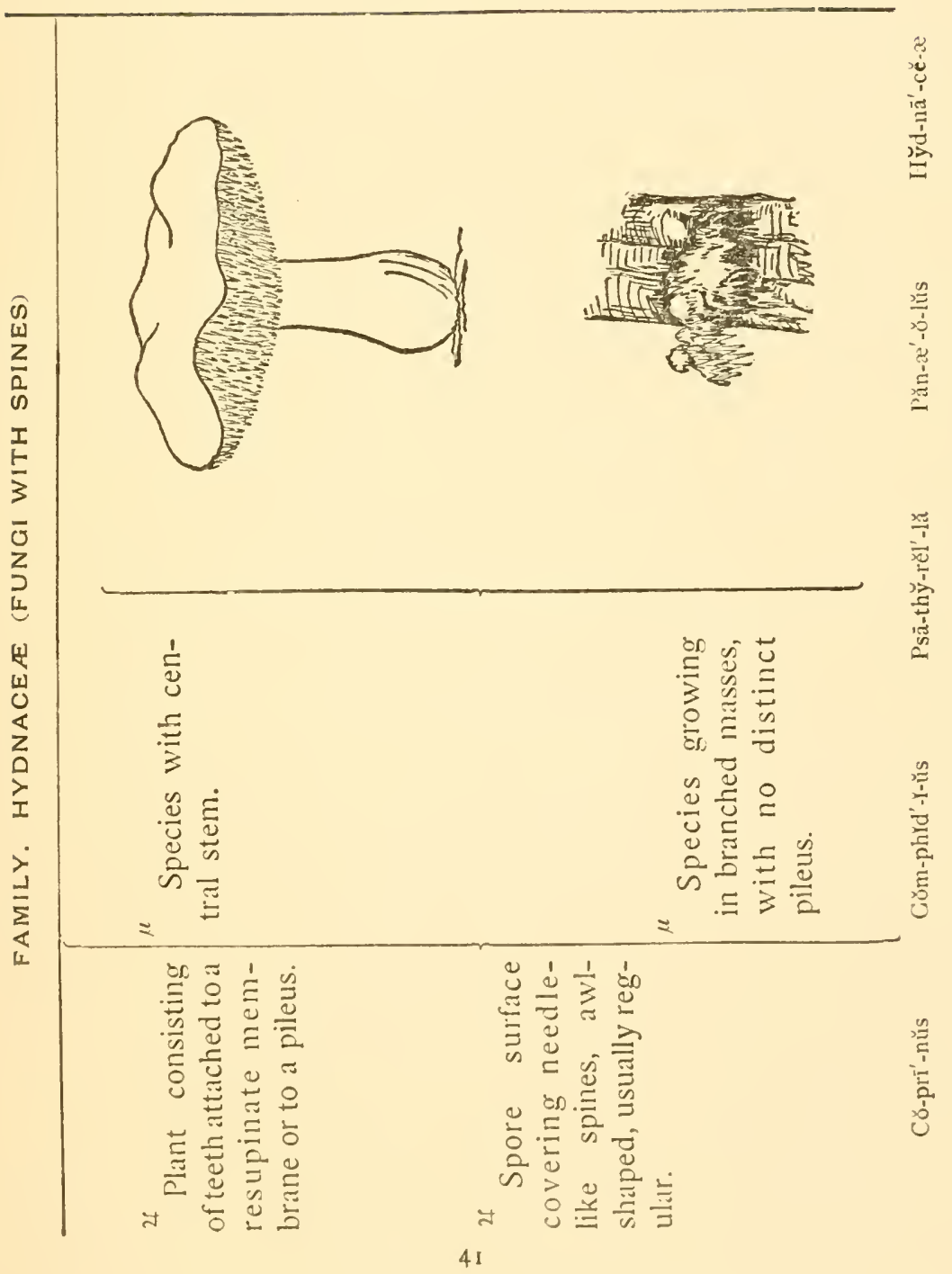




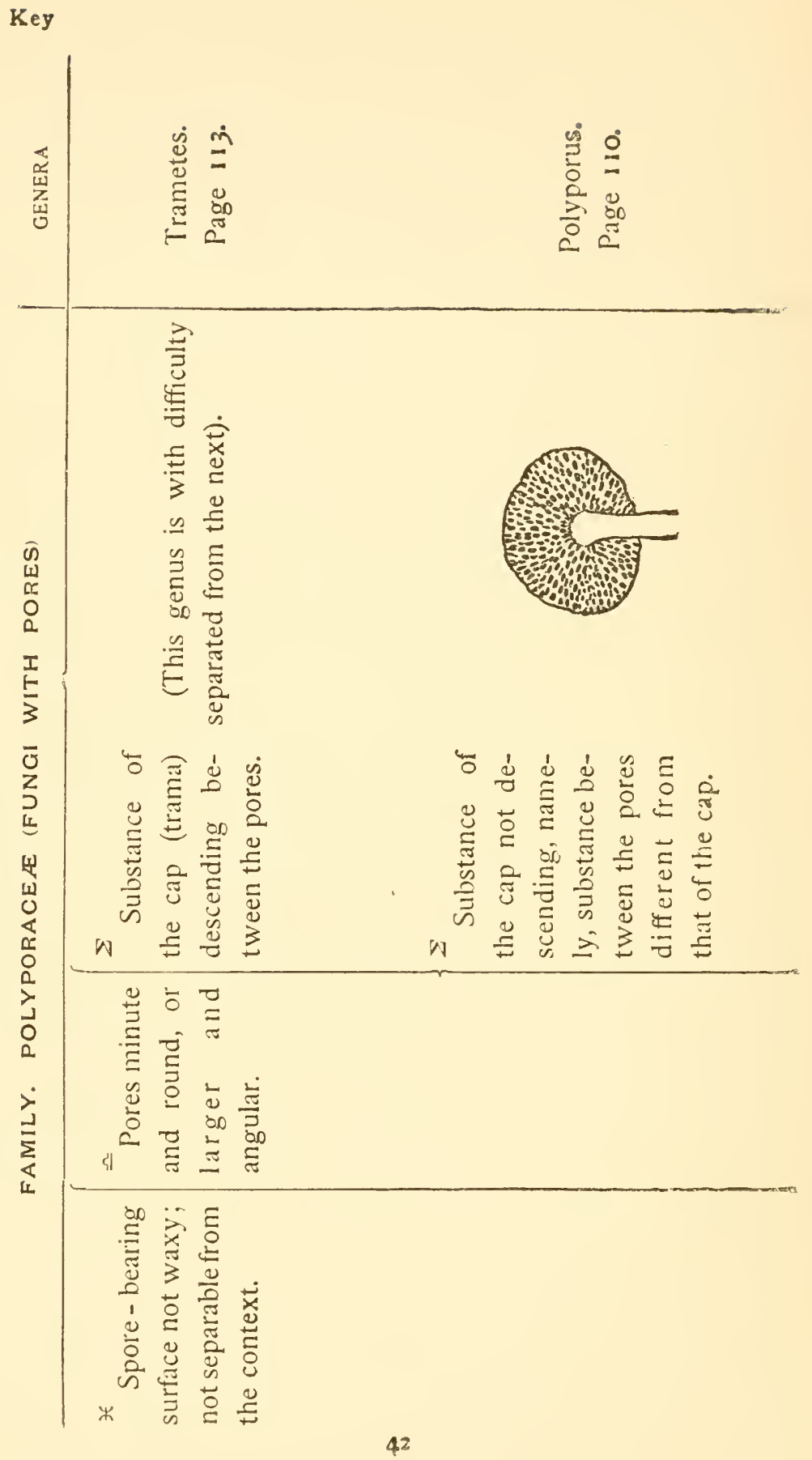


Key

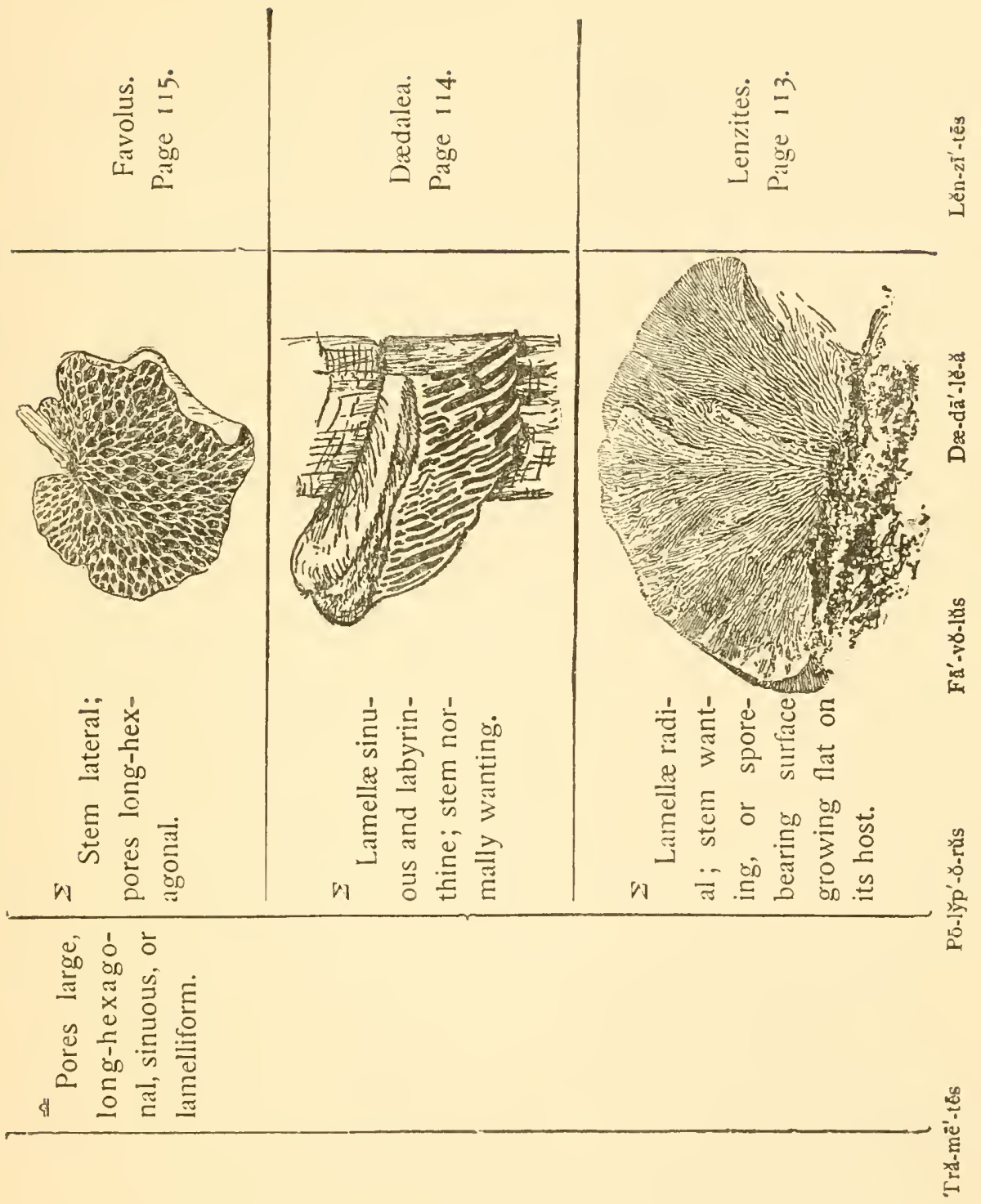




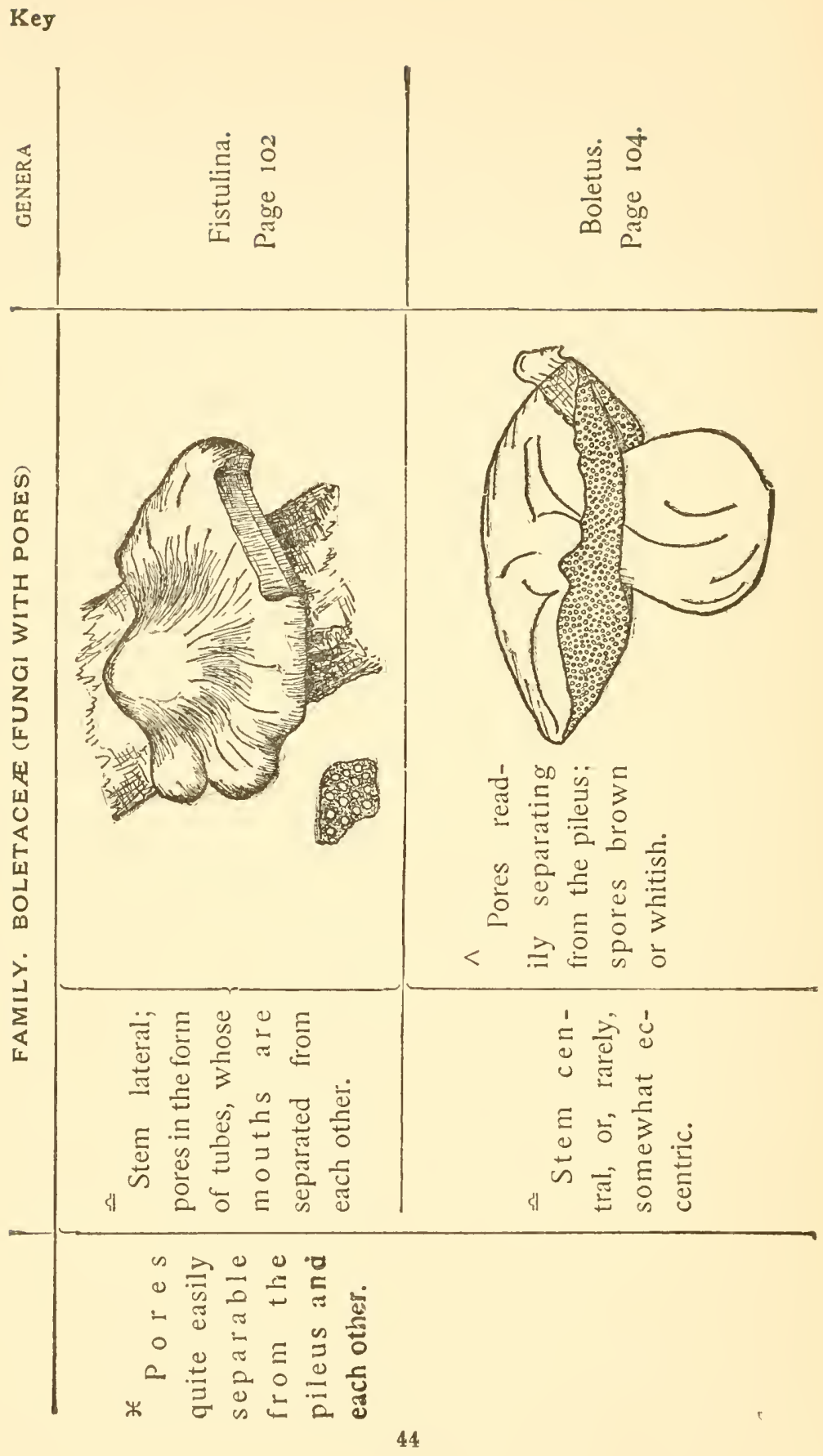


Key

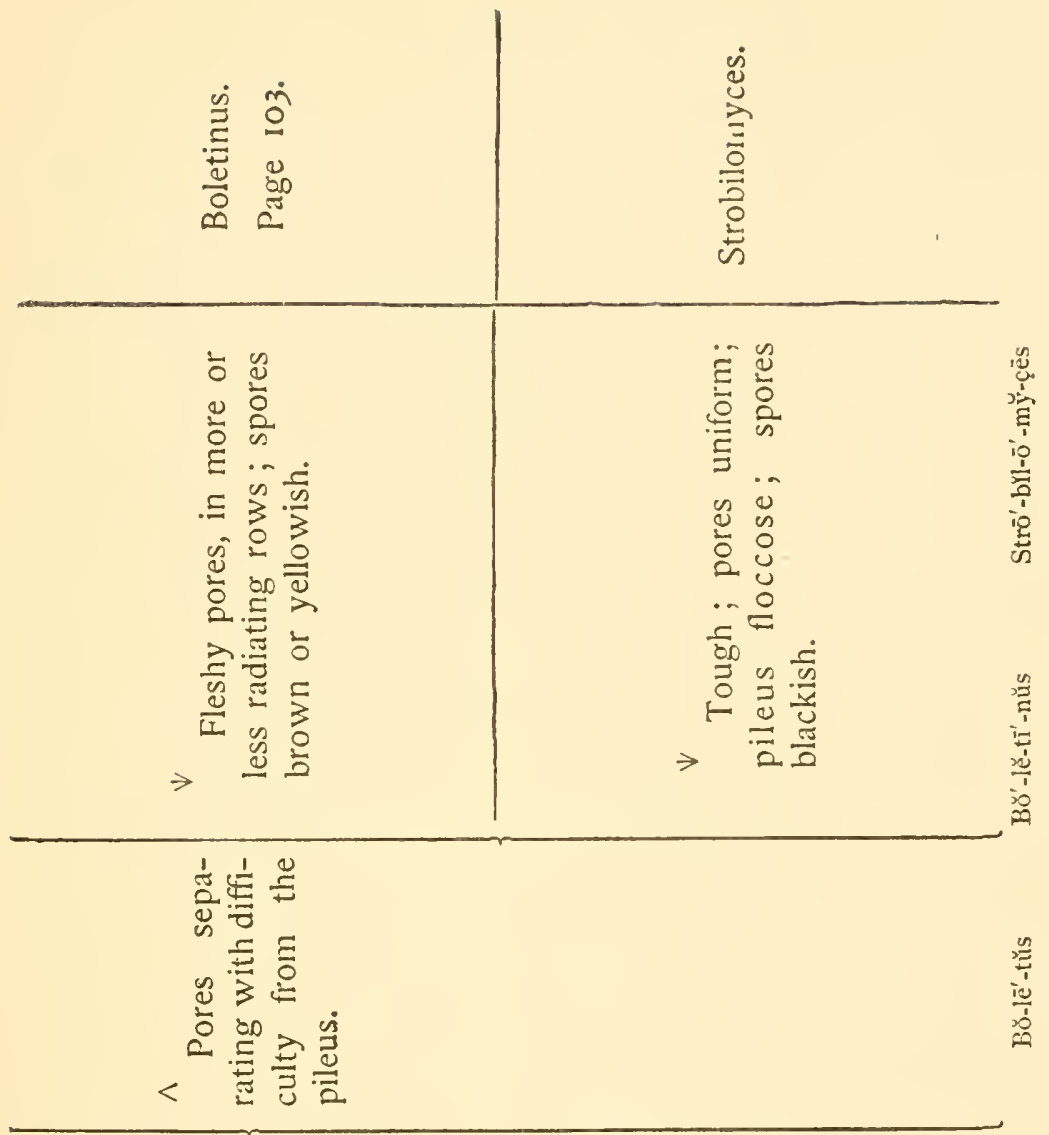




\section{CHAPTER V: FUNGI WITH GILLS \\ GENUS AMANITA}

THE fungi with gills all have this characteristic in commonthat they bear their spores on radiating plates or lamellæ. Their family name, Agaricacea, is derived from a typical member of the family, Agaricus campestris. The family is the largest and most widely distributed of all the families, and contains some five thousand described species, which are placed in groups or genera, more or less large, based on such characters as the colour of the spores; the position and shape of the lamellæ; the colour and texture, as well as the shape, odour, taste, and appendages of the cap and stem.

The colour of the spores is one of the most important characteristics, as the decision as to whether the plant is wholesome or not often rests upon it. The colour may be determined by placing the cap, with spore surface down, on a sheet of white or black paper, and leaving it for a time under an inverted glass, so as to cut off all drafts which may blow the spores away. A print of the radiating gills will then be made in the colour of the sporeswhite, pink, rusty brown, or black.

For external characters of the stem, one must be careful to get the entire stem from the ground; for a most important characteristic, the volva, if present, will be found at the base. The volva may be membranous and attached to the base, excepting at the rim, or membranous and loose, or present only in the form of rings of scales at the base, with perhaps traces on the surface of the cap.

The surface of the stem may be smooth or rusty or mealy white. It may or may not have near the cap a ring of the membrane which covered the gills of the young plant.

The character of the lamellæ and the internal characters of the stem may best be determined by cutting the cap and stem from top to base with a sharp knife, for then it may be seen whether the gills are free from the stem or attached to it, or 
whether they grow down on the stem; and whether the stem is hollow, solid, or filled with web-like mycelium, and whether it is fleshy or hals a tough and hard rind. The lamellæ may be of different or of equal lengths, and their edges may be entire or toothed or thin or blunt.

To know a genus of the gill-bearing fungi, one must know the cap, gills, stem, and habit of growth which characterise that genus.

A very young plant of the genus Amanita is enveloped in a membranous wrapper. The relation of the young plant to the wrapper will readily be understood by cutting a young plant through its length.

As the plant grows, the wrapper is ruptured,

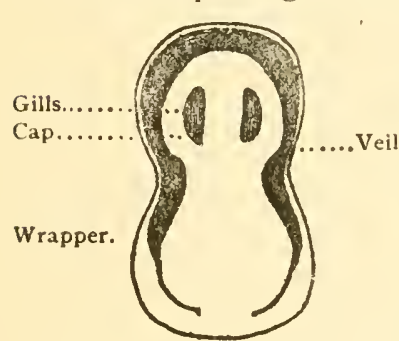

Section of young plant in wrapper a part is left at the base to form a cup or sheath, or a part may be carried up on the calp, to appear in small patches.

The cap is, as a rule, regular and

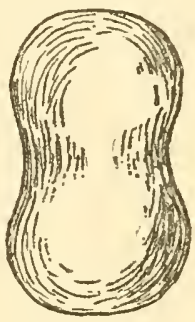

Young plant in wrapper broadly convex. It may be almost flat when mature. The stem has a conspicuous collar and the gills are free from the stem.

There are twenty American species in the genus Amanita; some of them are the most poisonous patches. fungi known, while others are most highly esteemed for the table. Since Free gills

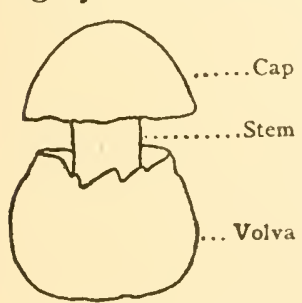

Wrapper ruptured the most dangerous species belong to this genus, it would be better for the amateur not to eat of specimens which havestalks

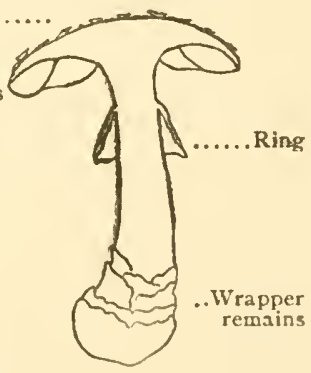

A. muscaria (See Plate III.) with a swollen base surrounded by a cuplike or scaly envelope, especially if the gills are white. In gathering all white-gilled species, care should be taken to get $\breve{A}$-măn'-Y-tă 
below the base of the stalk; for it often happens that the bulb is broken off and left behind, and thus the principal characteristic lost which would mark it as a specimen not to be eaten.

\section{Death Cup; Poison Amanita (Poisonous)}

\section{Amanita phalloides}

Cap or Pileus-White or greenish or greyish brown; smooth, no striations; width, $3-5$ inches.

Stem or Stipe-Ring present. Abruptly bulbous at the base; bulb margined by the wrapper remains. White in whitecap forms, tinged with a paler shade than the cap in browncap forms. Pithy when young, hollow when old. 3-6 inches long.

Veil-White in white-cap forms, tinged with brown in browncap forms.

Gills or Lamelle-White, free from the stem, rounded at the stem end, rather broad.

Spores-Globose and white.

Flesh-White.

Time-July to October.

Habitat-Woods, groves, open places, and pastures.

The poisonous principle of the death cup is known as phallin, one of the tox-albumins, the poisons found in rattlesnakes and other venomous animals, and the poisons which produce death in cholera and diphtheria.

The phallin acts directly upon the blood corpuscles, dissolving these, so that the serum of the blood escapes from the bloodvessels into the alimentary canal and drains the whole system of its vitality. There is no known antidote by which the effects of phallin may be counteracted. If one has eaten of the Amanita phalloides, the only chance of saving life is to remove the undigested parts from the alimentary canal by stomach-pump and oil purgatives; then, if the amount of phallin absorbed into the system is not too great, the remainder may wear itself out on the blood and the patient may recover.

The amount of the fungus which is necessary to produce death is small; even the handling of specimens and the breathing in of spores affect some people unpleasantly.

Phăl-loi'-dēs 


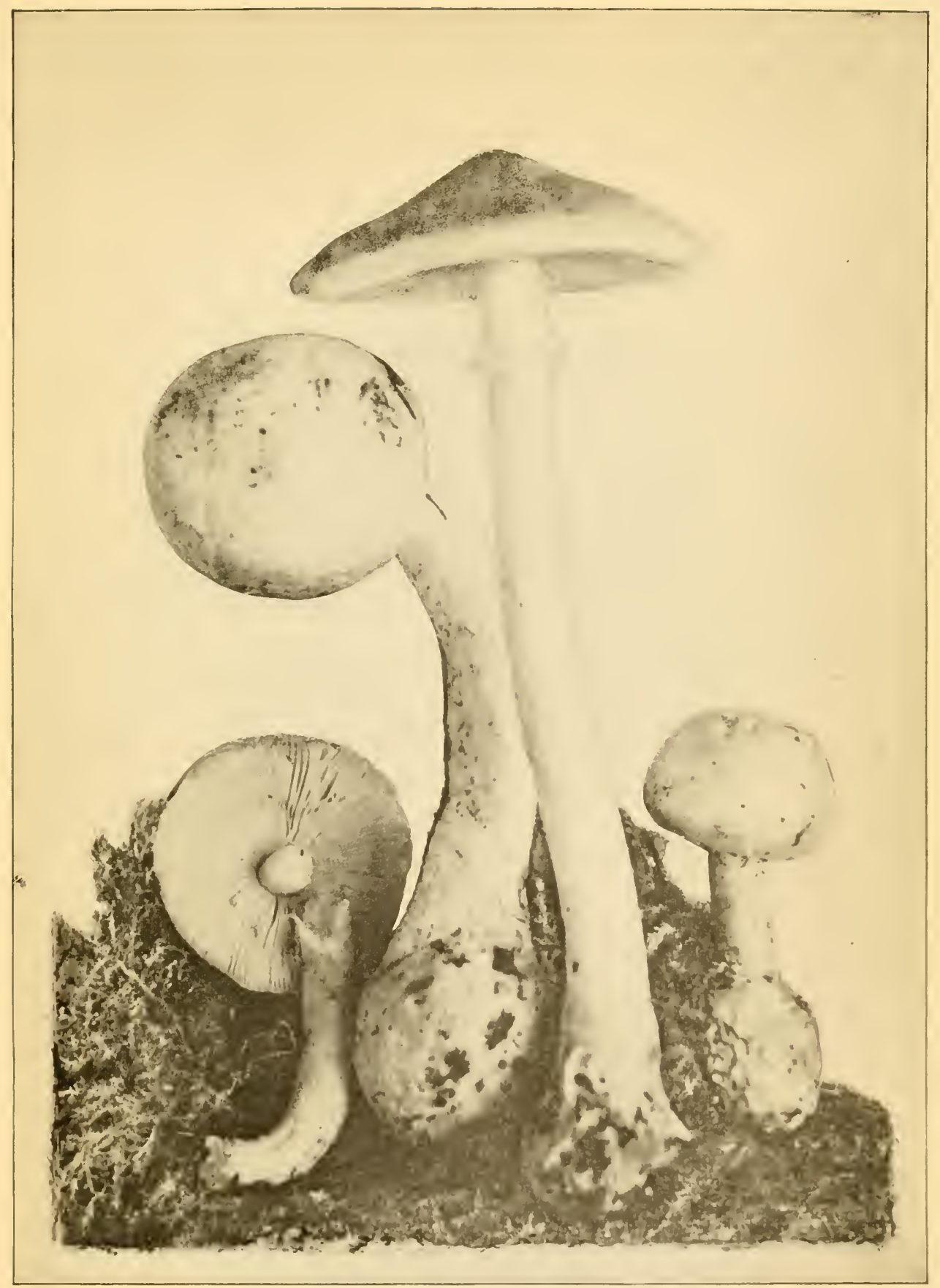

DEATH CUP. DESTROYING ANGEL

(Amanita phalloides, Fries)

Reduced. Nat. size: Cap, $3^{1} \cdot$ inches: $^{\prime} \operatorname{stem}^{1}, 7^{1}$ inches 




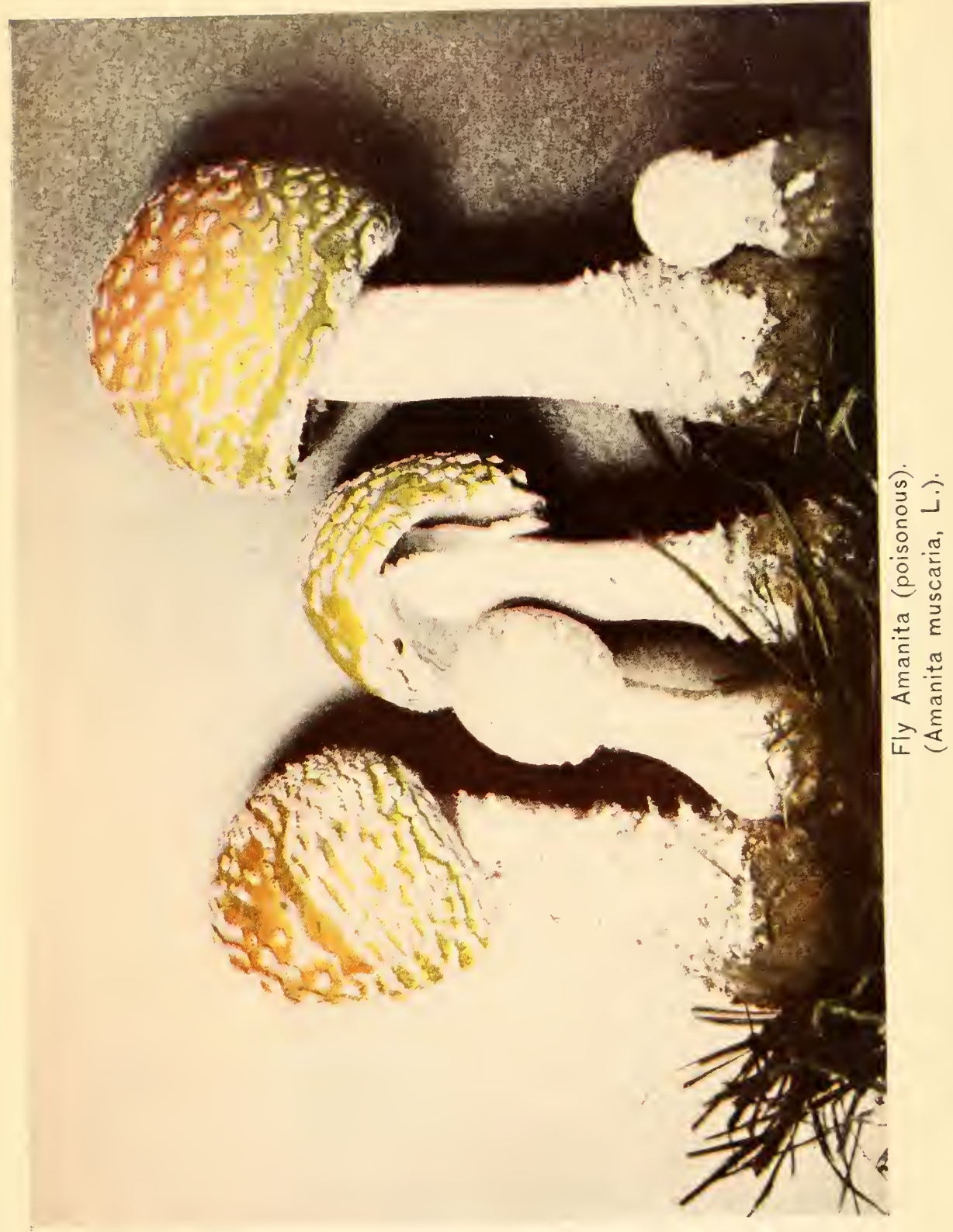




\section{Fly Amanita (Poisonous)}

\section{Amanita muscaria}

Cap or Pileus-Orange red to pale yellow or almost white. The young plants are brighter, and fade from the margin inward as the plant matures. Floccose scales, the wrapper remains, are scattered on the cap. The margin is often striate. 3-6 inches broad.

Stem or Stipe-White or slightly tinged with yellow. Pithy or hollow. Base not broad and abrupt, but ovate, covered with the scaly margins of the wrapper. 4-6 inches long.

Veil and Ring or Annulus-The veil covers the gills of the young plant, and later is seen as a collar-like ring on the stem.

Gills or Lamella--White or slightly tinged with yellow. Various in length; short ones terminating in length with almost vertical abruptness.

Spores-White, broadly elliptical.

Flesh-White, tinged with yellow under the epidermis.

Habitat-Along roadsides, on borders of fields, in groves of coniferous trees. It prefers poor soil, gravelly or scanty. It grows singly, not in groups.

Time-June until freezing weather.

Young Plant-This is at first egg-like, then dumb-bell shaped. As the parts within expand, the wrapper breaks up into scales, so that the convex, unexpanded cap is densely covered with more or less concentric fragments of the wrapper, and the bulbous stem is covered with rings of fringy scales. As the stem expands, these scales are left on the bulbous base, while the fragments on the cap are more widely separated by the growth of the cap.

The fly amanita is a very conspicuous and handsome species. There are conflicting statements concerning the properties of this fungus; some claim that it is edible, and yet it is known to have caused much sickness and many deaths. It caused the death of the Czar Alexis of Russia, and of the Count de Vecchi in Washington. It is said that it is cooked and eaten by the Russians, and still it is on record that several French soldiers ate of it in Russia and became very ill.

The Siberians steep dried specimens of the fly amanita in whortleberry juice, and thus make a drink which produces an intoxication similar to that produced by the "haschisch" and "majoon" of the East.

$$
\text { Mŭs-cā'-ry-ă }
$$


There is something about it particularly attractive to flies, and yet for them to sip its juices means death, as may be seen by the circle of dead flies lying on the ground under the shadow of its cap.

The chief poison of this fungus is an alkaloid called muscarine, which paralyzes the nerves controlling the action of the heart. Injections of atropine in doses of from one one-hundredth to one-fiftieth of a grain are employed as an antidote for this poison. In addition, the most powerful emetics are used.

\section{Orange Amanita (Edible)}

\section{Amanita Casarea}

Cap or Pileus-Smooth, glabrous, and free from warts or scales. Red or orange, fading to yellow on the margin or all over the cap. Margin distinctly striate. When fully ex-

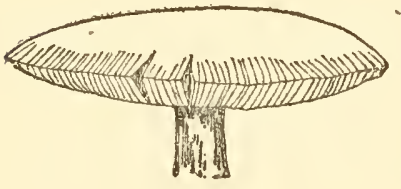

Cap striate, and free from warts panded, nearly flat. When moist, slightly sticky and viscid.

Stem-Yellow. When young, fibrous or cottony within, later hollow.

Wrapper or Volva-White and membranous, loosely sheathing the base of the stem.

Veil-Covers the gills of the young plant. Remains are seen on the stem only, where it hangs down like a white ruffle.

Gills or Lamella-Rounded at the stem end and not attached to the stem. Yellow, an

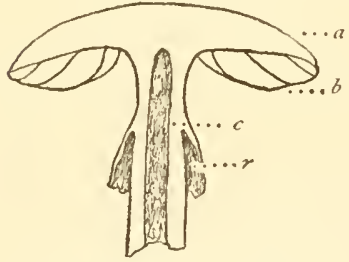

Section of A. Cæsarea

(a) Smooth cap (c) Hollow stem

(b) Free gills (r) Ruffle-like ring exception to the rule that the colour of the gills in mature plants resembles the colour of the spores.

Young Plant-When young, the cap

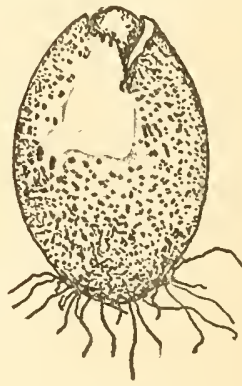

Young plant and stem are contained in a wrapper not unlike a hen's egg in shape, size, and colour. As the cap and stem within develop, the wrapper ruptures in its upper part, the stem elongates, and the cap is carried up, C象'-să-rē'-ă 

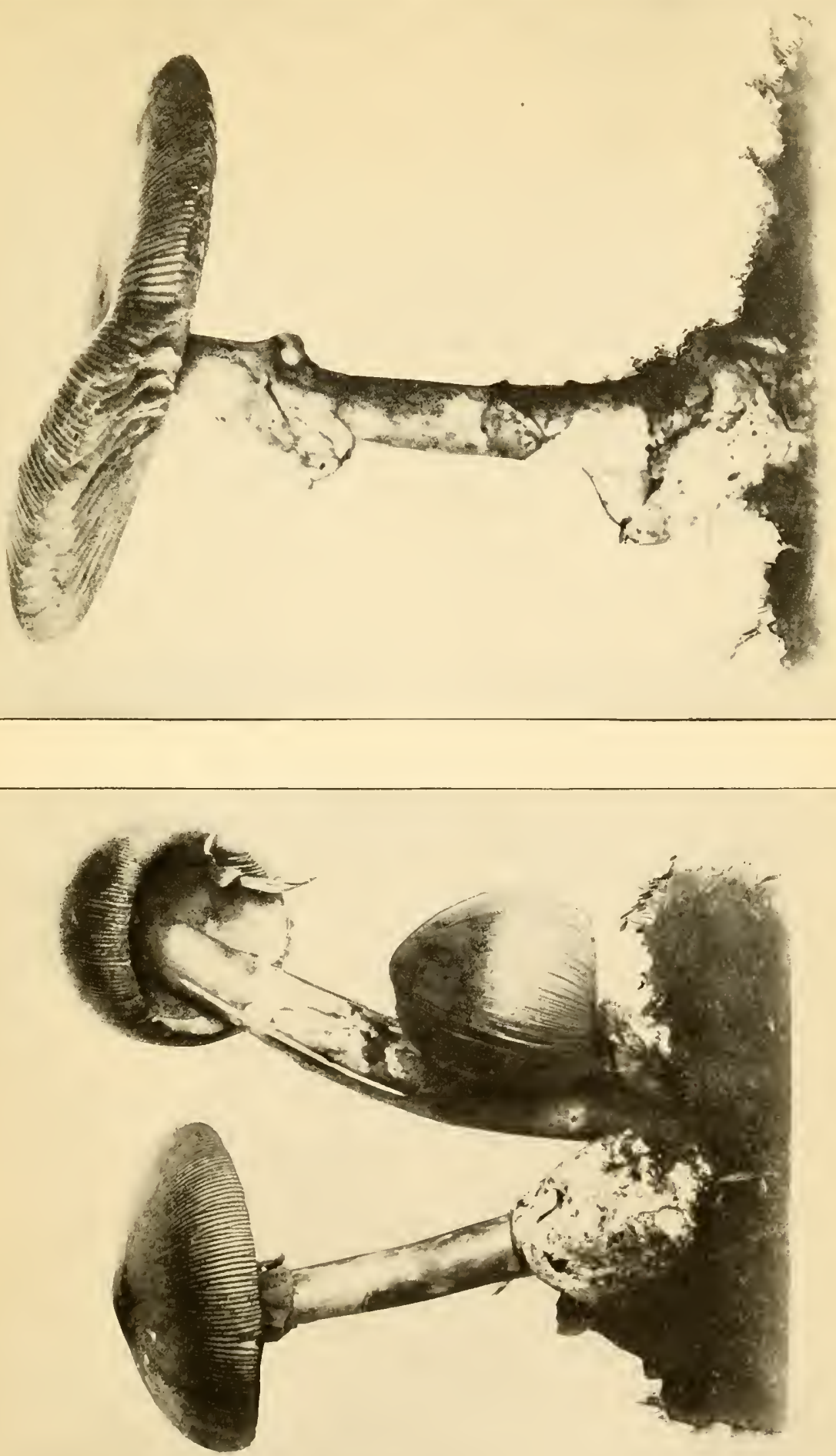

while the remains of the wrapper are left at the base of the stem, an open sac.

Spores-White, elliptical.

Flesh-White stained with yellow under the separable epidermis and next the line of attachment of the gills.

Taste-Mild and pleasant.

Habitat-Thin woods, preferably pine woods and sandy soil.

Abundant in southern Europe, common in the Southern

States, and occasionally found in New York and Massachusetts.

Zime-July, August, September.

The Amanita Cosarea is one of the handsomest species. The Greeks and Romans esteemed it as an article of food. The names, "Food of the gods," "Cibus Deorum," "Imperial mushrcom," "Cæsar's mushroom," and "Kaiserling," suggest the esteem in which it was held. 
Fungi with Gills

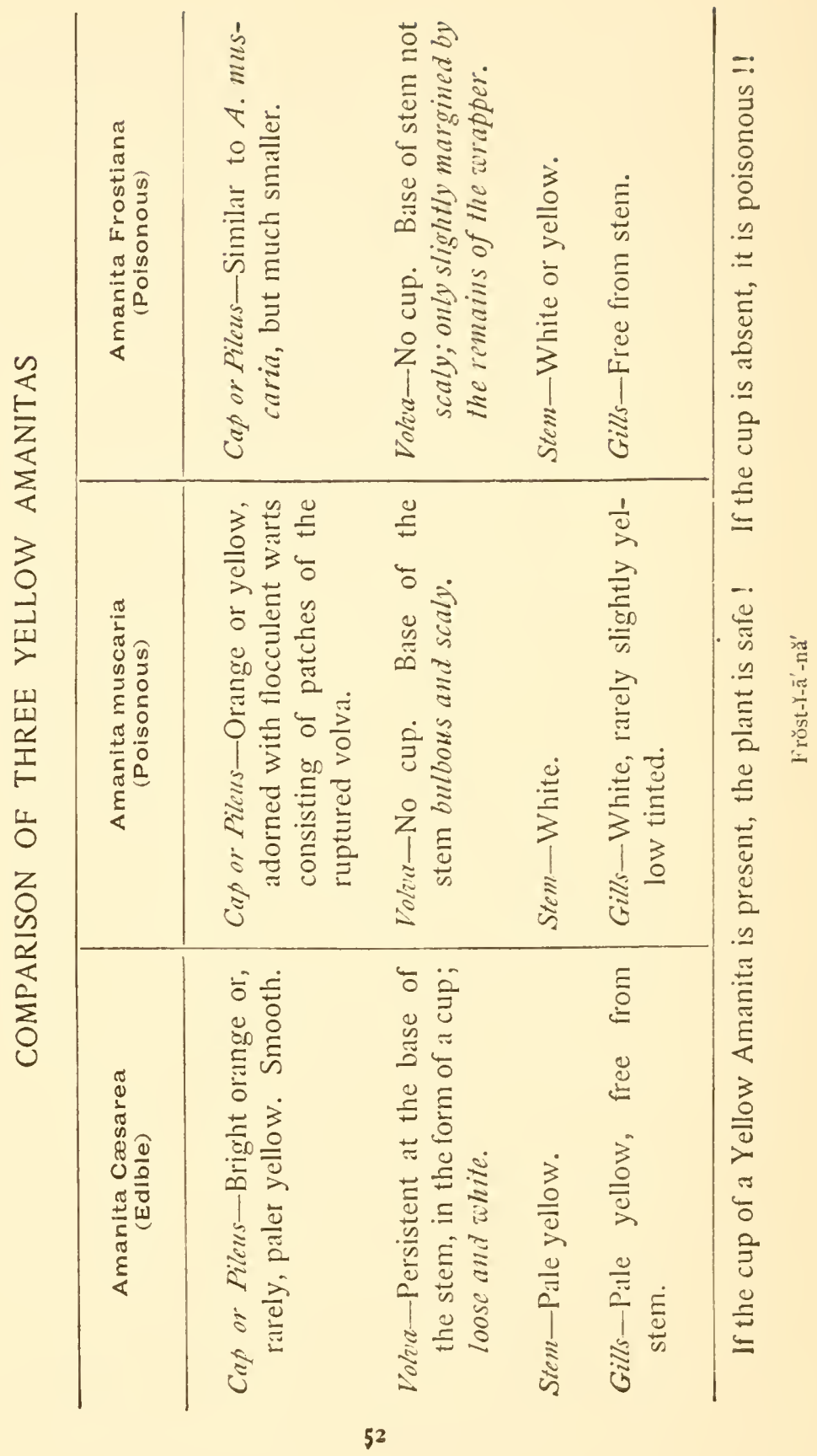





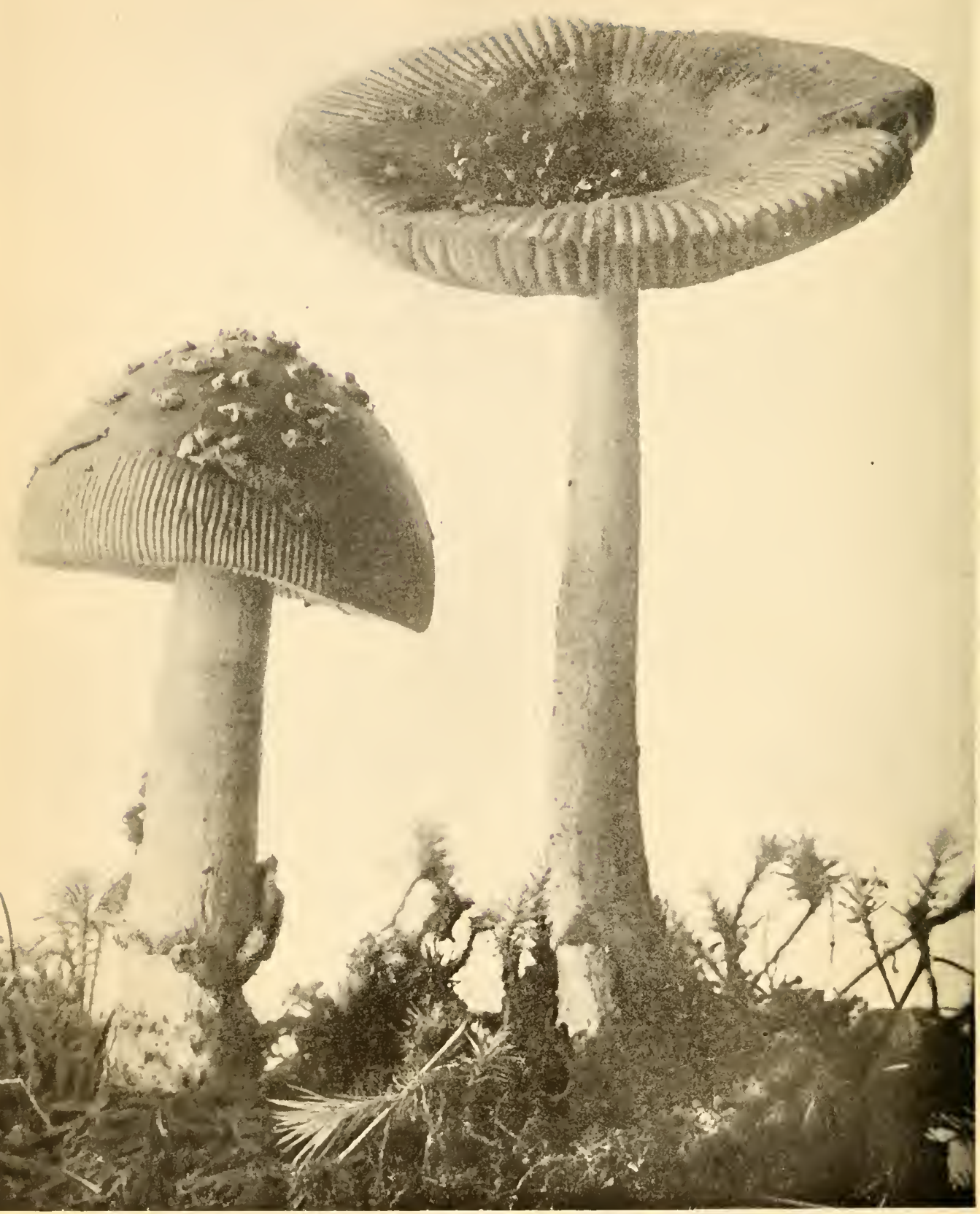

STRANGLED AMANITOPSIS (EDIBLE)

(Amanitopsis strangulata, Fr., Roze)

Cap greyish brown; wrapper fragments dark brown. See Genus, p. 53 


\section{GENUS CANTHARELLUS}

The members of the genus Cantharellus differ from all other gill-bearing fungi in that the gills are in the form of shallow folds growing down the stem. The folds are generally narrow and forked or branching. The name Cantharellus, meaning little cup or goblet, refers to the shape of the fungus, some of the species being so deeply depressed that a cup not unlike a tall goblet results.

\section{Cantharellus floccosus (Edible)}

(See Plate Facing Page 136)

Cap or Pileus-Funnel form or trumpet shaped, depressed even into the stem. The surface of the depression is woolly or scaly. The scales sometimes persist and sometimes disappear. Reddish yellow, fading to yellow.

Gills or Lamella-Blunt, narrow, close; forked branched so as to appear as a network. Yellow to yellow brown. Stem or Stipe-Short, smooth, or hairy. Sometimes extending like a root among fallen leaves.

Spores-White.

Flesh-White, thin.

Time-July to September.

Habitat - In groups in woods. The specimen pictured was found growing in moss by a stream among laurels and rhododendrons.

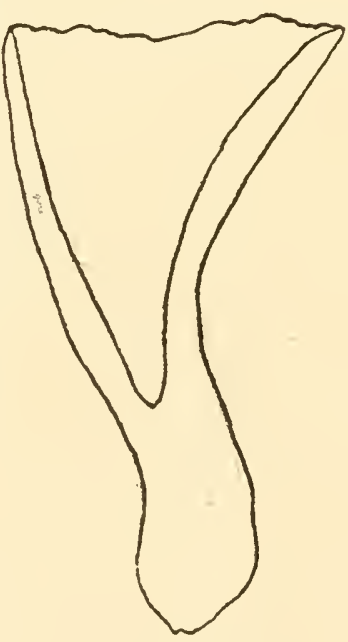

Section of C. floccosus

\section{GENUS AMANITOPSIS}

The genus Amanitopsis has white spores, the gills free from the stem, and at the base of the stem a volva, the remains of the wrapper which enclosed the young plant. There is $n 0$ annulus or ring on the stem, a feature which separates the genus Amanitopsis from the genus Amanita.

Căn-thă-rěl'-lŭs
Ă-man'-โ-เด็p'-sไs 


\section{The Sheathed Amanitopsis (Edible)}

\section{Amanitopsis raginata}

Cap or Pileus-Variable in colour, ranging from white to reddish brown. Thin, fragile, smooth; or, when young, with a few fragments of the wrapper adhering to its surface. Margin

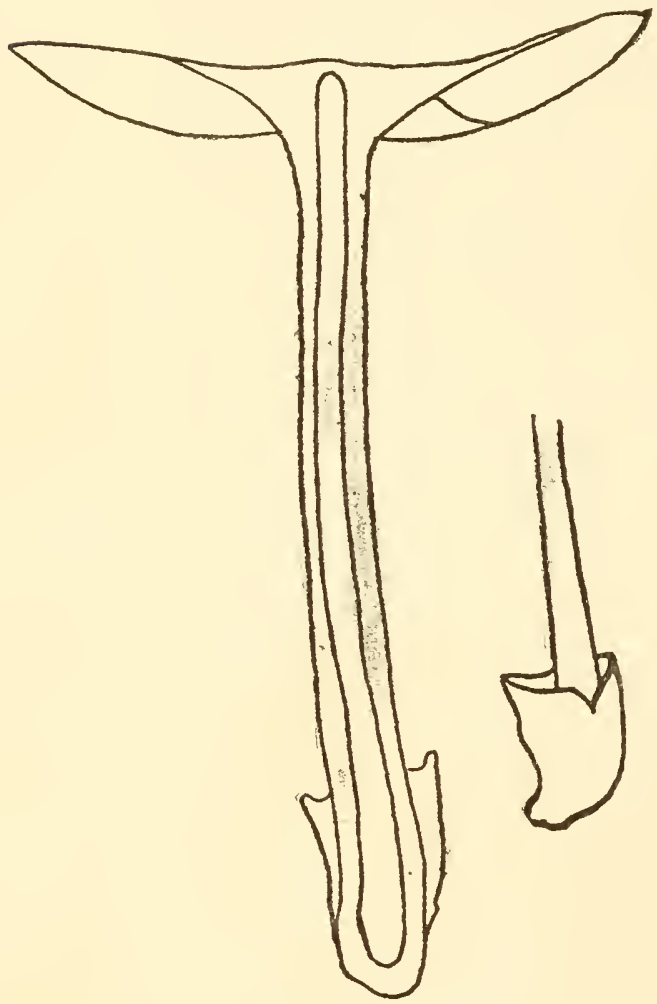

Section of A, vaginata

distinctly and deeply striated. $2-4$ inches broad. Stem or Stipe-Hollow or stuffed; smooth, or sprinkled with minute mealy particles or woolly scales. Not bulbous at the base. 3-5 inches long. Spores-White.

- Ring or Annulus None.

Wrapper or VolvaSoft, flabby, white, adhering slightly to the base.

Gills or Lamella-Free from the stem. White or whitish, close, irregular.

Flesh-White, or $\mathrm{s}$ o met i m e s stained under the easily separating skin.

Time-June to October.

Habitat-In woods or open places, in damp vegetable mould, widely distributed. Specimen pictured was found growing in mountains of New Jersey.

A. vaginata, var. alba, has the whole plant white.

$A$. vaginata, var. fulvia, has the cap tawny yellow.

A. vaginata, var. livida, has the cap leaden brown, and gills and stem tinged with smoky brown.

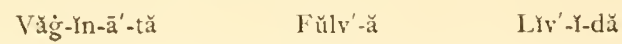




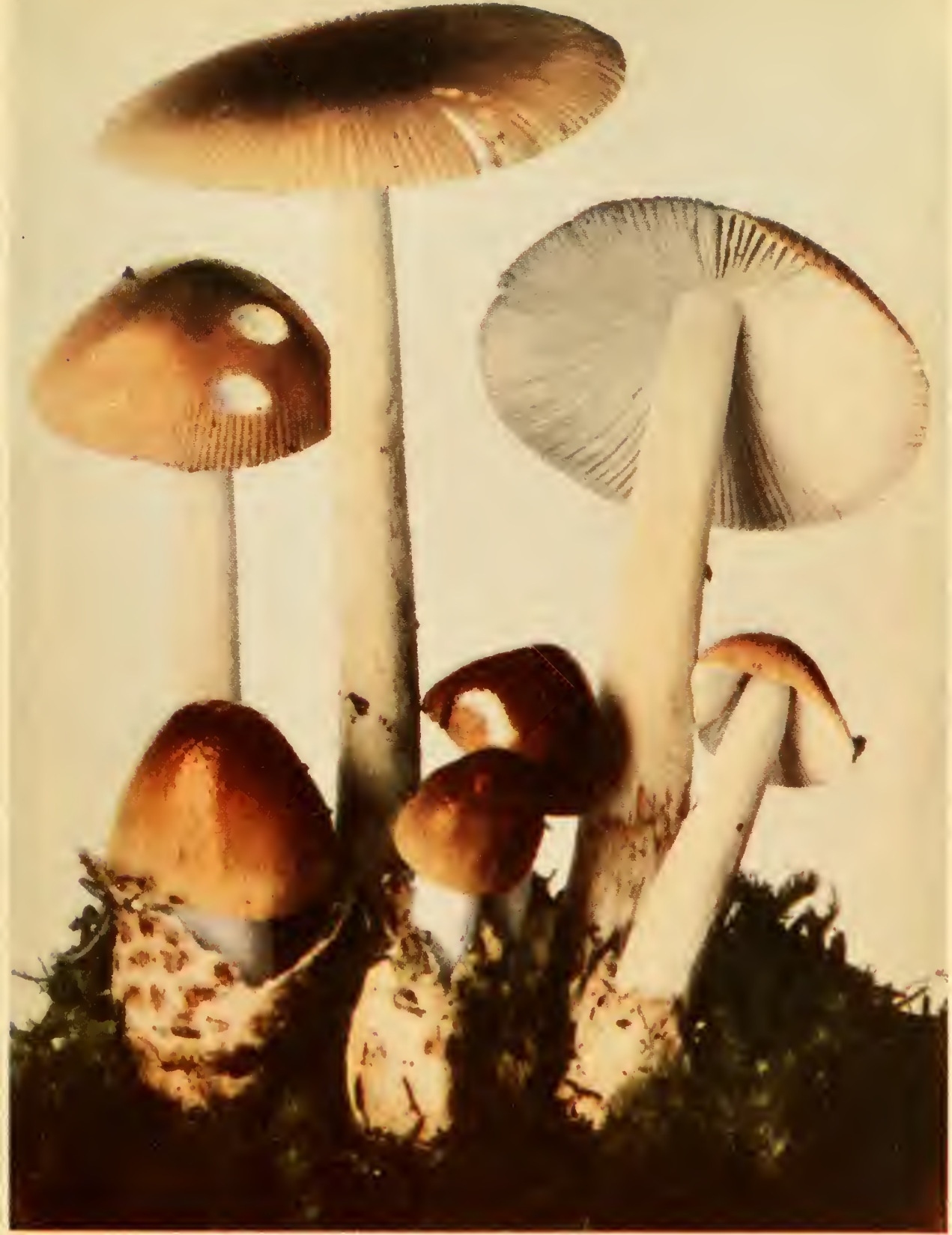

Sheathed Amanitopsis (edible).

(Amanitopsis vaginata, Roze). 



\section{Amanitopsis parcivolvata (See Frontispiece)}

Cap or Pileus-Convex, then expanded ; smooth, free from warts. Colour brilliant orange red over the whole cap; not yellow on the margin, not fading with age. Uniform in colour in young and old specimens. Margin with striations deep and long. Gills or Lamella-Lemon yellow, free from stem, and rounded at the outer extremity. Stem-Slightly tapering toward the cap; hollow. Clear lemon yellow, covered with meal-like particles.

Ring or Veil-None in old or young specimens. Volva-Present; not large and loose. White; clinging closely to the stem in the form of scales.

Spores-White.

Flesh-Unpleasant raw odour. White, stained with orange red immediately under the skin.

Habitat-Mixed woods. New Jersey, North Carolina.

Time-July.

The caps of the specimens found in North Carolina varied in colour from parcivolvata (reduced) almost white to white with a red centre, and from orange or shades of orange to brilliant red.

\section{GENUS MYCENA}

The members of this genus have white spores; no volva nor annulus; lamella thin, with acute edges; gills with a little bay cut out near the stem, sinuate, and the stem with a cartilaginous rind. Cap membranous and striate on the margin-that is, with depressed parallel lines.

Mycena hæmatopoda (SeE Plate Facing Page 93)

Cap or Pileus-Bell-shaped; reddish brown, deeper shade on margin.

Gills or Lamcllie-Paler tint of colour of cap ; adnate.
1’ăr'-çŶ-vǒl-vā'-tă

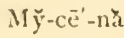
Hēm'-ă-tớp'-ð-dă 
Fungi with Gills

Stem or Stipe-Colour of cap; hollow; a mere tube, with thin walls. When cut quickly, it changes to a deep red brown and exudes a purple juice. Flexible, fragile.

Spores-White.

Ring or Annulus-None.

Time-September.

Habitat-Decayed wood in forest.

\section{GENUS LENTINUS}

The genus Lentinus has white spores, no annulus, and no volva. The stem is central or lateral, and the lamellæ are normally toothed on their margins. The species are leathery, fleshy, and tough ; will stand drying, and revive when moist.

Lentinus lepideus is one cause of the decay of telegraph poles, railroad ties, and bridges.

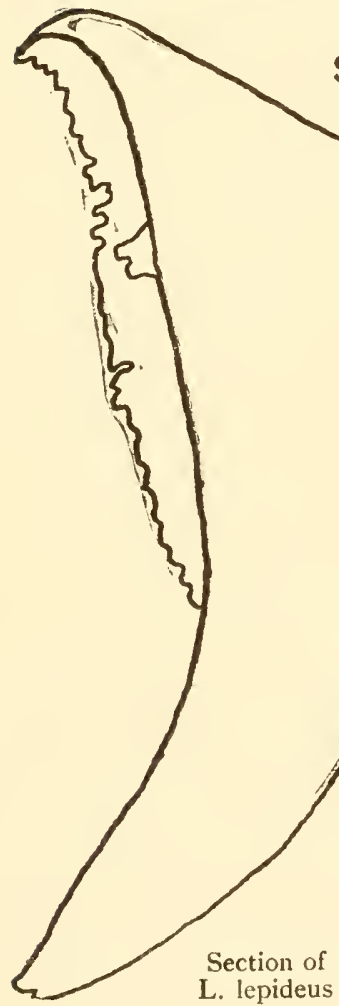

\section{Scaly Lentinus (Edible)}

Lentinus lepideus

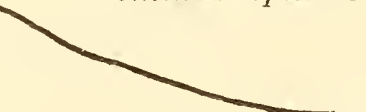




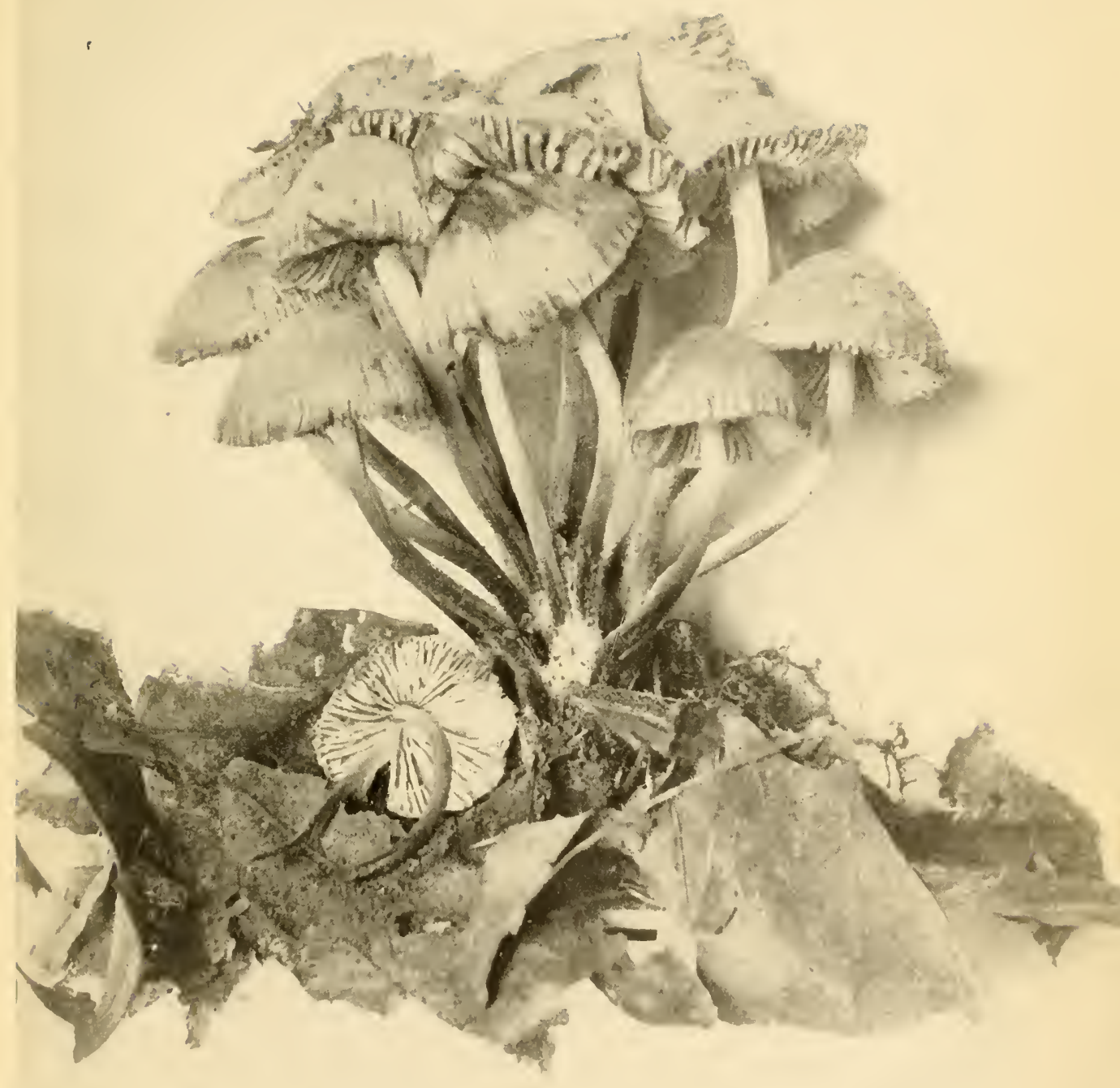

HELMET MYCENA (EDIBLE)

(Mycena galericulata, Scop.)

Cap greyish; gills white; stems firm, hollow, hairy at the base. Sec p. 55 




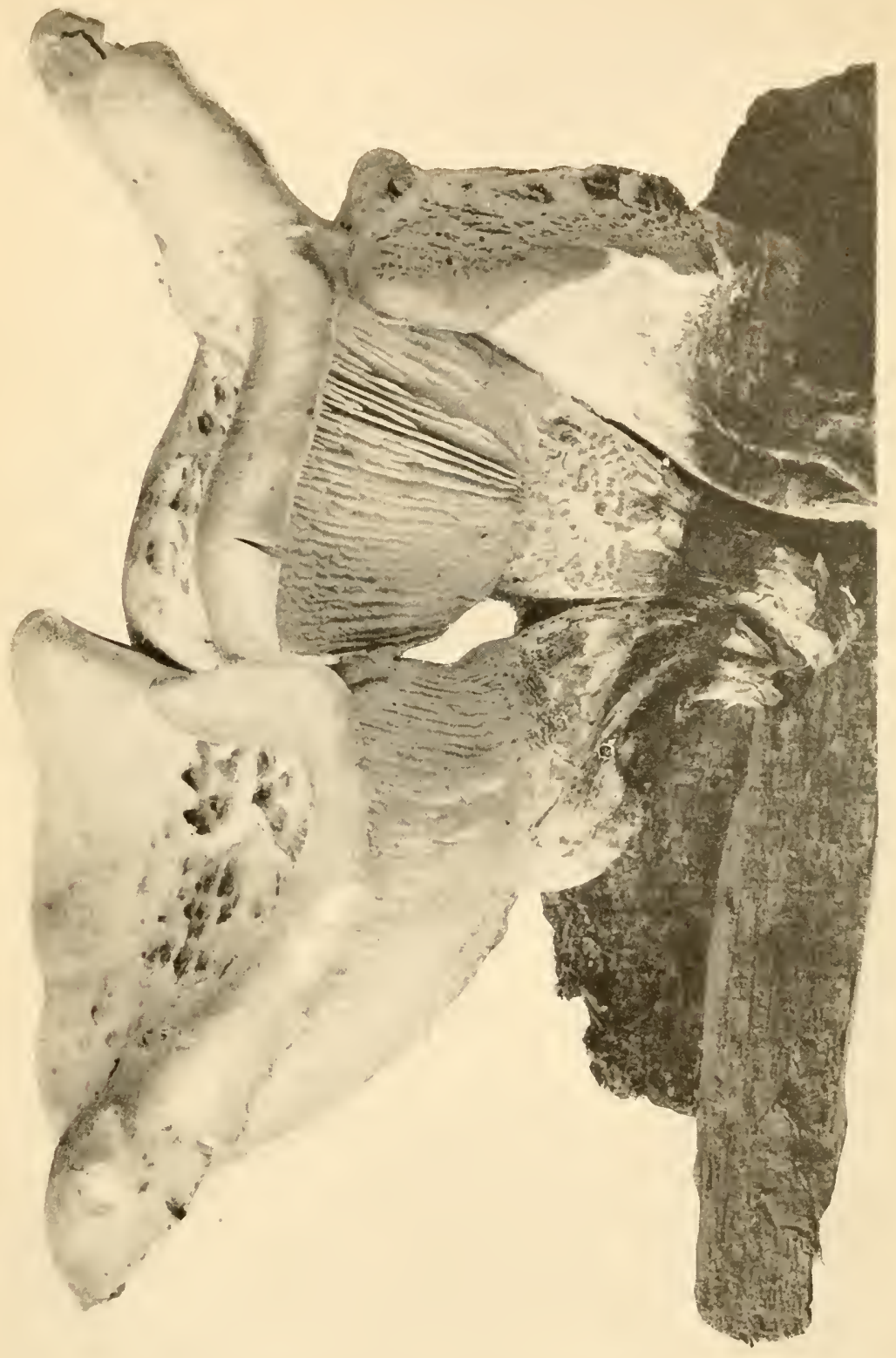

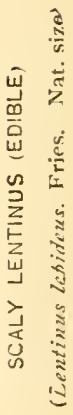


centric, straight, or curved; firm, solid, equal, or tapering at the base. 2-4 inches long.

Ring or Annulus-None.

Spores-White.

Flesh-White.

Time-June to August.

Habitat-On wood; common on railroad ties.

\section{GENUS PLEUROTUS}

In the genus Pleurotus the stem is attached to the cap at some point to one side of the centre. The stem may be on the very margin of the cap, or may be wanting altogether. The three species to be mentioned all grow on dead wood-either on dead trees or on dead branches of living trees.

$\checkmark$ The name Pleurotus comes from a Greek word meaning side, and has reference to the position of the stem.

\section{Oyster Mushroom (Edible)}

\section{Pleurotus ostreatus}

Cap or Pileus-Fleshy, convex, smooth, and moist. White, or tinted with ash colour or brown.

Gills or Lamella-White, or tinted with ash; broad; growing down the stem, and branching again and again at the base.

Stem or Stipe-Short or wanting.

Spores-White, oblong.

Flesh-White, tough.

Time-September.

Habitat-On dead wood. The specimens pictured were found growing on a dead forest tree at Lake Placid. The largest shells measured four inches across.

Plū-rō'-เŭs

Ǒs-trēe-à-'tŭs 


\section{Pleurotus sapidus (Edible)}

Cap or Pilcus-Convex or depressed, smooth, often irregular. White, yellowish, ashy grey, dull lilac, or even brownish; overlapping each other. $2-5$ inches broad.

Gills or Lamelle-Whitish, rather distant, growing down the stem, branching and connecting again at stem end.

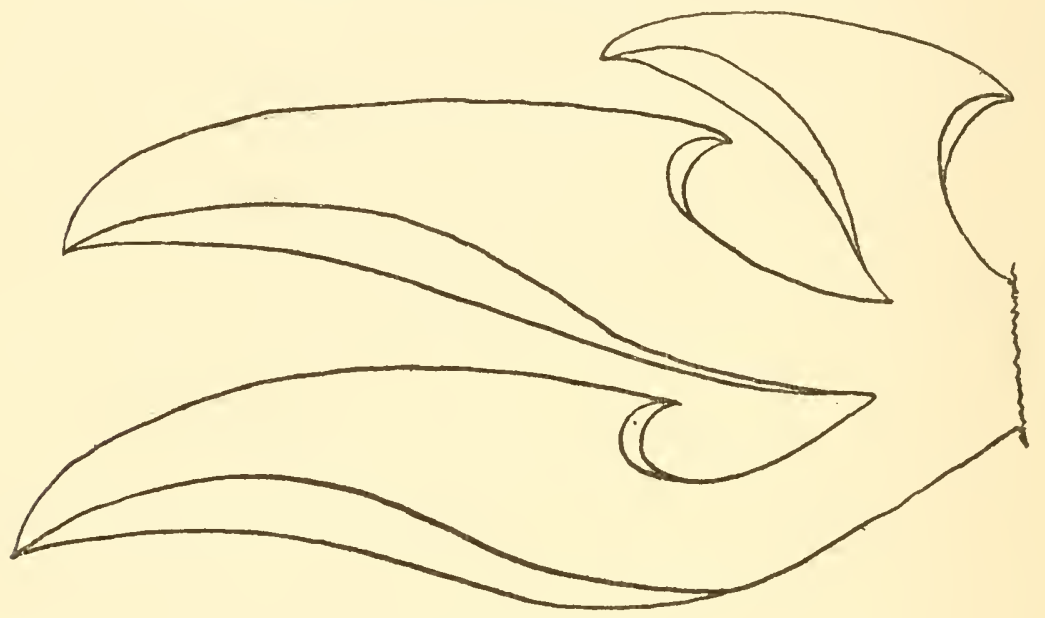

Section of P. sapidus

Stem or Stipe-Stems more or less united at the base, eccentric or lateral, smooth, whitish. I-2 inches long.

Spores-Lilac, oblong.

Time-lune to November.

Flesh-White, tough.

Habitat-In clusters, often from a common stem, growing on decayed wood.

\section{Elm Pleurotus (Edible)}

\section{Pleurotus ulmarius}

Cap or Pileus-Convex or nearly flat, firm, smooth. White, tinted at the centre with reddish yellow or brownish yellow. $2-5$ inches broad.

Gills or Lamella-Broad, not crowded, notched at the stem end, growing down the stem. White, turning yellow with age.

Stem or Stipe-United to the cap one side of the centre. Usually curved ; solid, smooth, or downy. White or whitish. 2-4 inches long.

$$
\text { Săp'-Y-dŭs }
$$

Uัl-mā'-ry-uัs 



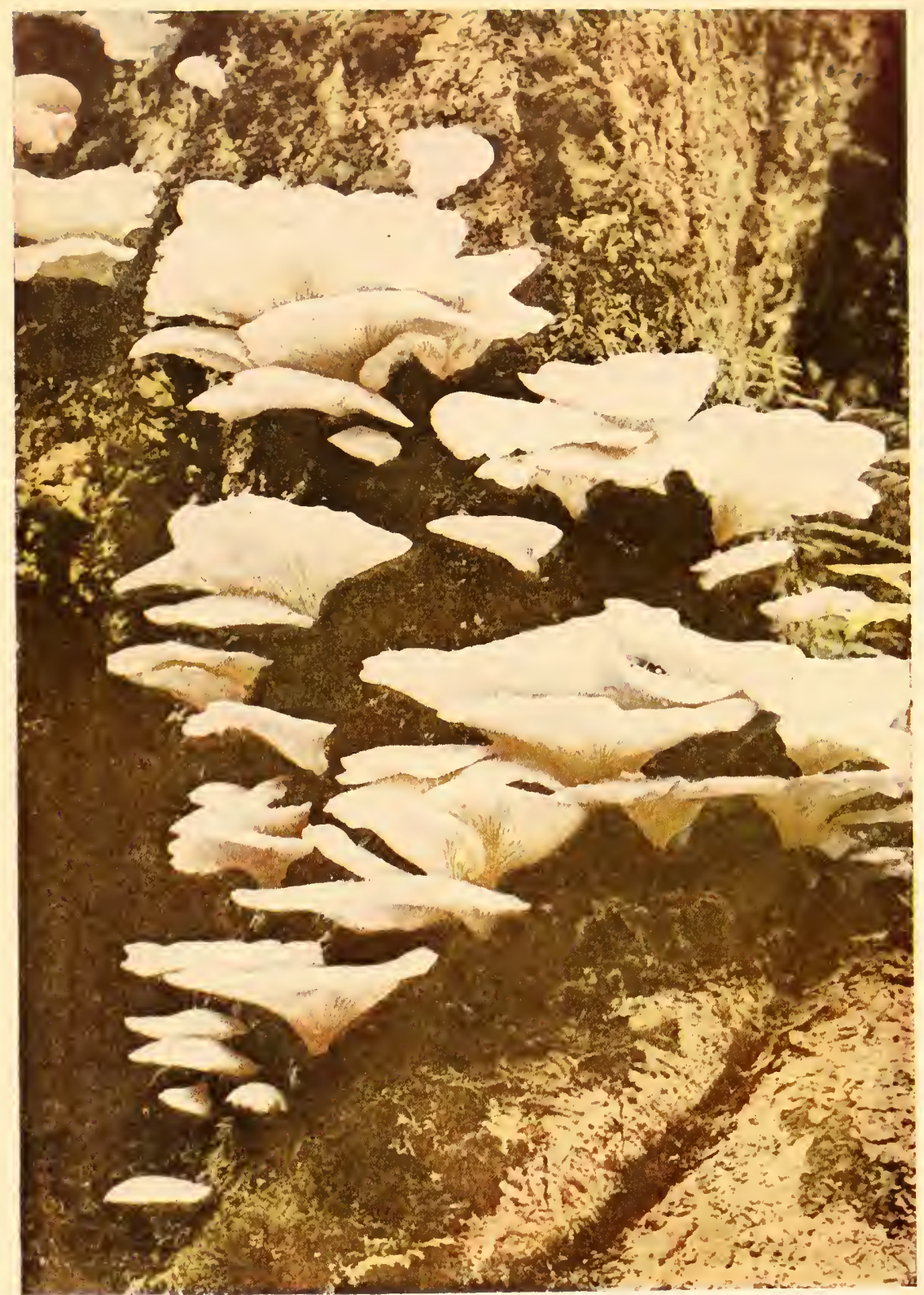

Oyster Mushrooin (edibie).

(Pleurotus ostreatus, Fr.)

Reduced. See page 57. 


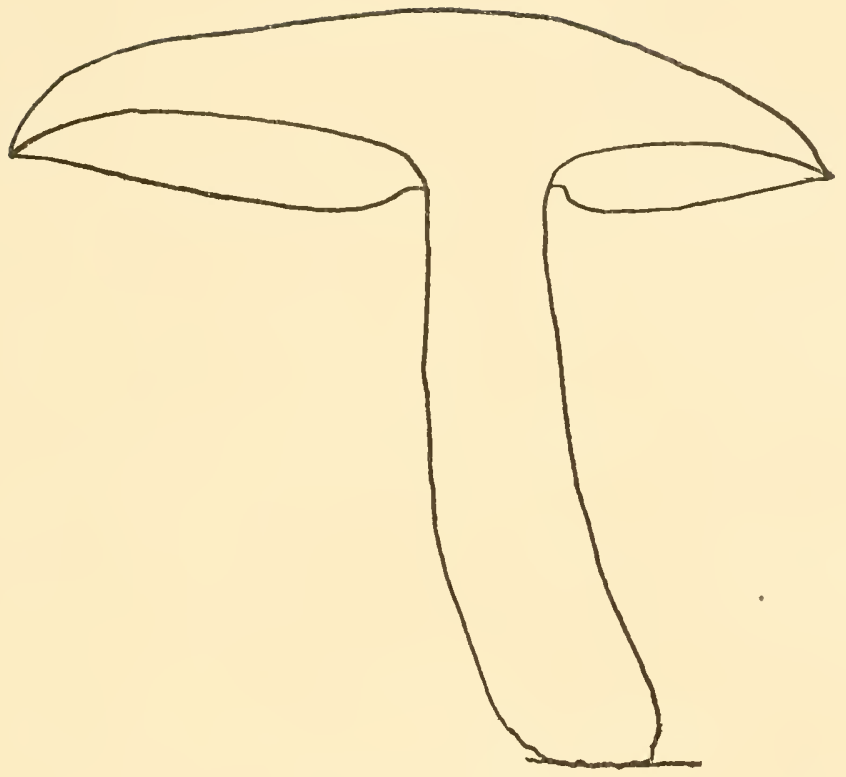

Section of P. ulmarius

Flesh-White, not tender, agreeable flavour.

spores-White, globose.

Tine-September to November.

Habitat-Conspicuous on dead parts of standing elms. Large and white. Sometimes found on other than elm trees.

\section{GENUS HYGROPHORUS}

The members of this genus may be recognized by their moist caps and by the waxy nature of their gills, which usually grow downward on the stem (decurrent), and are not very closelv placed side by side. No species is known to be dangerous.

\section{Chantarelle hygrophorus (Edible)}

Hygrophorus cantharellus (SeE Plate Facing Page 60)

Cap or Pileus-Thin, convex at first, but later depressed. Covered with minute scales. Moist, bright red, becoming clange or yellow. $1 / 2-1$ inch broad. 
Gills or Lamelle-Distant, somewhat arched, growing downward on the stem (decurrent). Yellow, sometimes tinged with vermilion. Unequal.

Stem or Stipe-Smooth, not truly solid, sometimes hollow. Coloured like the cap, whitish within. 2-4 inches long.

Ring or Annulus-None.

Spores-White.

Flesh-Disagreeable in flavour.

Habitat-Swamps and damp, shaded places; in fields or woods. Common. The specimen photographed was found in dense mixed woods, Lake Placid.

Var. H. rosea has the cap expanded and the margin wavy.

Var. H. flava has the cap and stem pale yellow, the gills arched and strongly decurrent.

Var. H. flavipes has the cap and stem red or reddish.

Var. H. flaviceps has the cap yellow and the stem reddish.

\section{Vermilion Hygrophorus (Edible)}

\section{Hygrophorus miniatus}

Cap or Pileus-Thin, fragile at first, convex, becoming nearly flat. Smooth or minutely scaly. Often depressed. Red, fading to yellow or orange. $1-2$ inches broad.

Gills or Lamella-Distant. Usually yellow, sometimes tinged with red. Notched at the

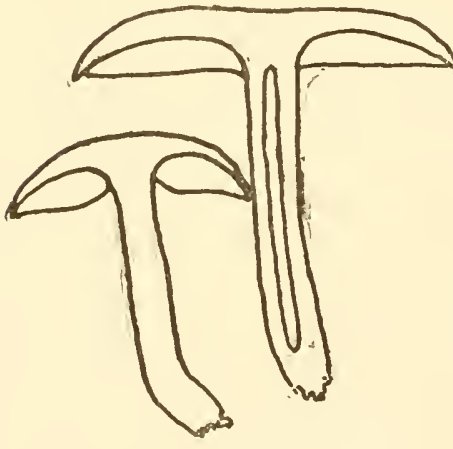

Section of H. miniatus stem end, or growing down the stem, or fastened to the stem by the entire width of the inner extremity of the gill. Stem or Stipe-Slender, smooth. Coloured like the cap. Solid when young, hollow when old. 1-2 inches long.

Ring or Annulus-None.

Spores-White, elliptical.

Flesh-Tender, and of agreeable flavour.

Time-June to September.

Habitat-Adapts itself to varying conditions. Singly, in groups, or in clusters, in bogs or on dry hillocks. The specimen photographed was found in woods, among fallen leaves and decayed wood, Lake Placid. 


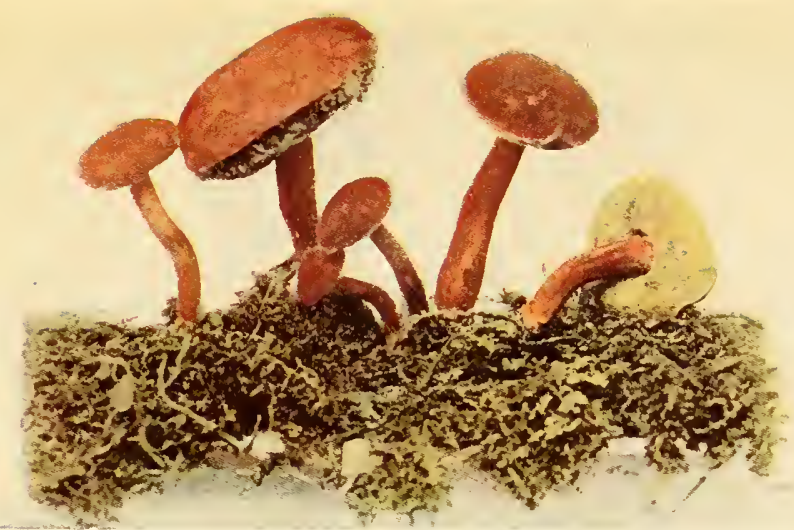

Golden-flesh Boletus. (Boletus chrysenteron, Fr.). Reduced. See page 106.

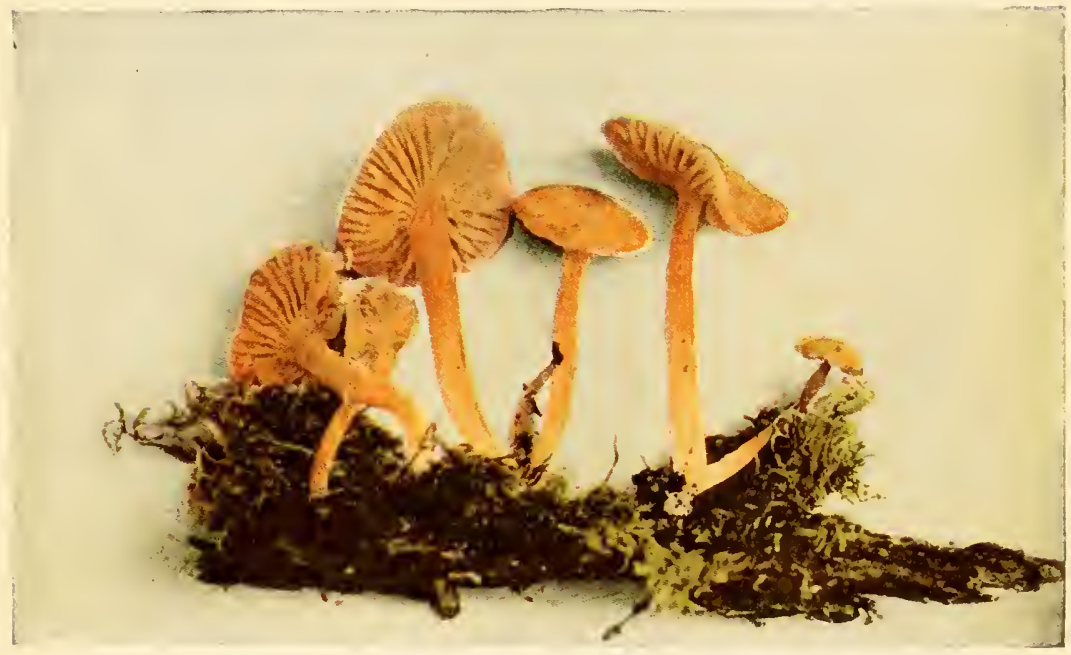

Vermilion Hygrophorus (edible). (Hygrophorus miniatus, Fr.). Reduced.

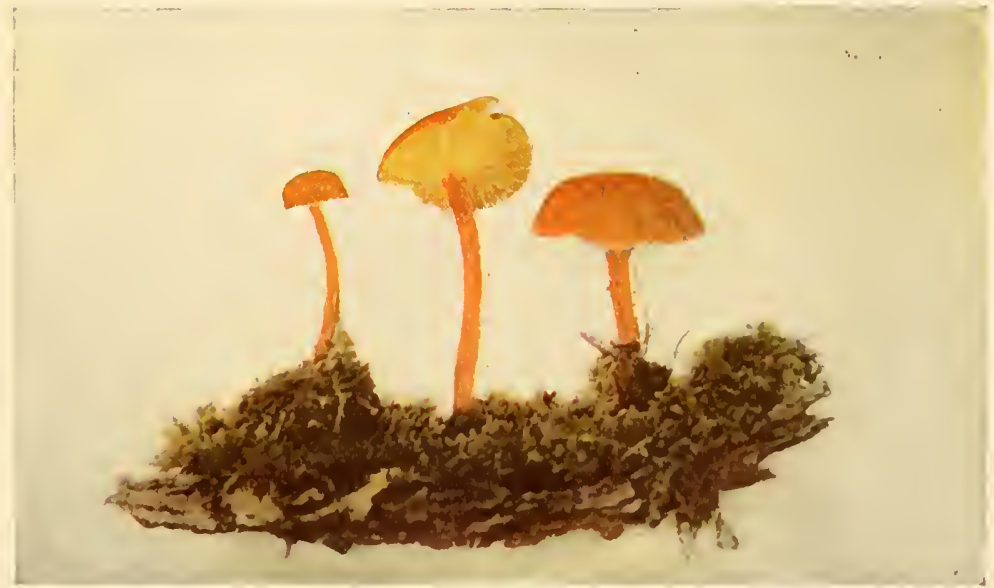

Chantere!le Hygrophorus (edible). (Hygrophorus cantharellus, Schw.) Reduced. Seo page 59. 




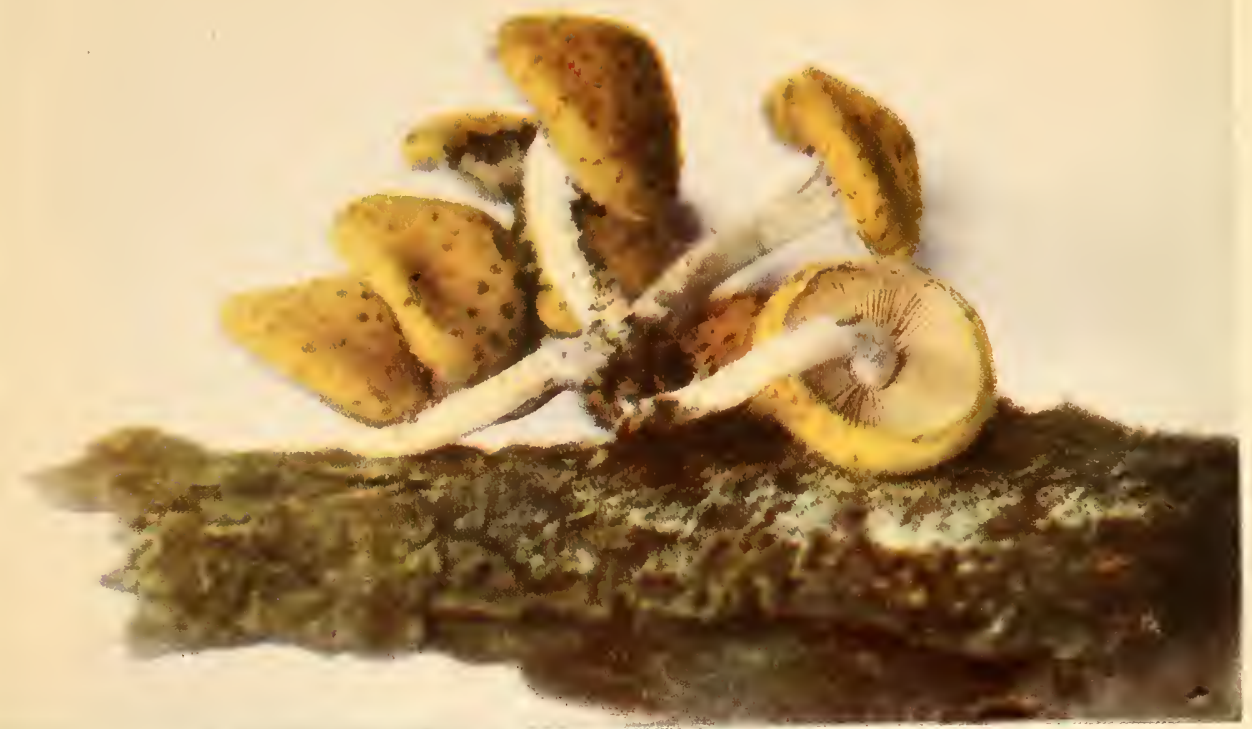

Fat Pholiota, (edible).

(Pholiota adiposa, Fr.) See page 83.

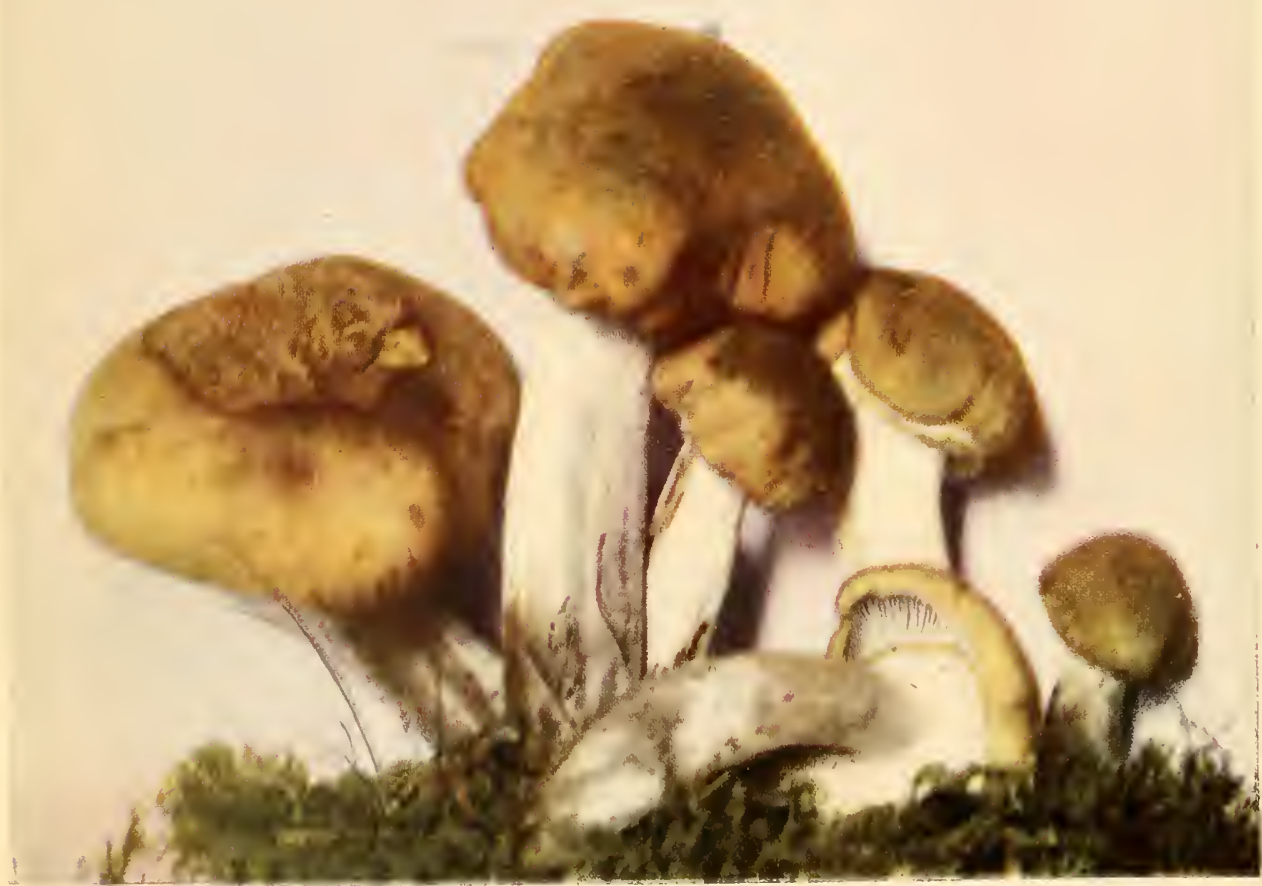

Honey-coloured Armillaria (edible).

(Armillaria mellea, Vahl). 


\section{Ivory Hygrophorus (Edible)}

\section{Hygrophorus eburneus (Se Plate Facing Page 84)}

Cap or Pileus-White, thin,fleshy, viscid. Stem or Stipe-White, unequal, long, slender, stuffed, or hollow; viscid. Gills or LamellaWh it e, wa $\mathrm{x} y$, unequal, distant, growing down the stem (decurrent), thick and firm.

Volva and Annulus Wanting.

Spores-White.

Flesh-O d o u r a n d taste grateful.

Time-September.

Habitat - The speci-

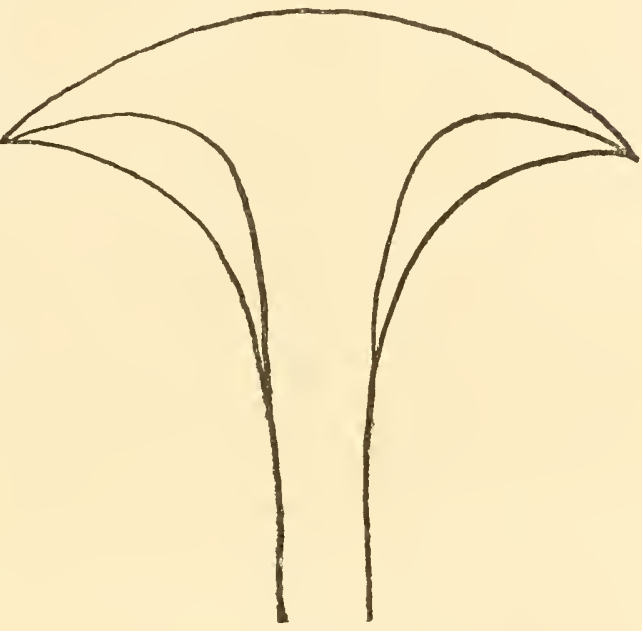

$m$ e $n$ photo-

graphed was found growing among moss and fallen leaves in dense wood, Lake Placid.

\section{GENUS ARMILLARIA}

The members of this genus have white spores, and the gills attached by the inner extremity to the stem. The stem has a collar, but no wrapper at the base. The name is derived from the Latin armilla, a bracelet, referring to the ring upon the stem.

\section{Honey-coloured Armillaria (Edible)}

\section{Armillaria mellea}

Cap or Pileus-Colour from almost white to dark reddish brown. Young plants have numerous minute tufts or scales of brownish or blackish hairs. Margins sometimes striated. 1-6 inches broad. 
Stcm or Stipe-Usually reddish brown, paler above than below. Uniform in thickness, narrowed or slightly thickened at the base. Firm externally; soft and spongy, or hollow within. 1-6 inches long.

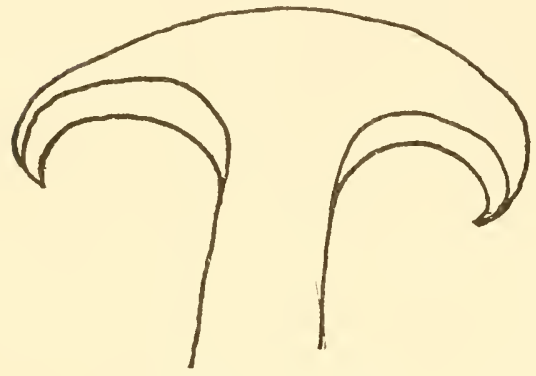

Section of A. mellea King or Annulus-Cotiony to membranous, sometimes lacking in old plants.

Gills or Lamella - Si m p ly joined to the stem or running down it. White or whitish ; sometimes variegated with reddishbrown spots.

Spores-White, elliptical.

Flesh-White or whitish. Taste unpleasant or acrid. Quality inferior.

Habitat-Common in woods or in cleared land, on the ground or on decayed wood. Solitary or clustered.

Time-Abundant in September. - Found in June.

Var. obscura has cap covered with numerous small, blackish scales.

Var. flava has cap yellow or reddish yellow.

Var. glabra has cap smooth.

Var. radicata has tapering stem which penetrates the earth deeply.

Var. bulbosa has bulbous base.

Var. exammulata has cap smooth, margin even, stem tapering, annulus slight and evanescent, or wholly wanting.

The Armillaria mellea has a disagreeable taste when raw, but when cooked it is thought by some to be very good. Dr. Peck says he does not know of any unwholesome species for which it may be mistaken. The Amillaria mellea has the habit, very unusual for a member of the group of Agaracales, of producing from its mycelial threads tuber-like masses of fungal substances from which the fruiting capsarise. The fungal masses of the Armillaria, the so-called sclerotia, are ribbon or string like, and may be found between the wood and bark of cone-bearing trees. These sclerotia send out cylindrical branches, called rhizomorphs, which may penetrate the soil and attack the roots of other trees, and so continue their work of destruction in the forest.
Ŏb-scü'-ră
Flāv'-ă
Glā'-bră
Răd-I-cā'-tă
Bŭl-bō'-să
$\breve{E} x-a ̆ n^{\prime}-n u ̄-1 a^{\prime}-$ tă 



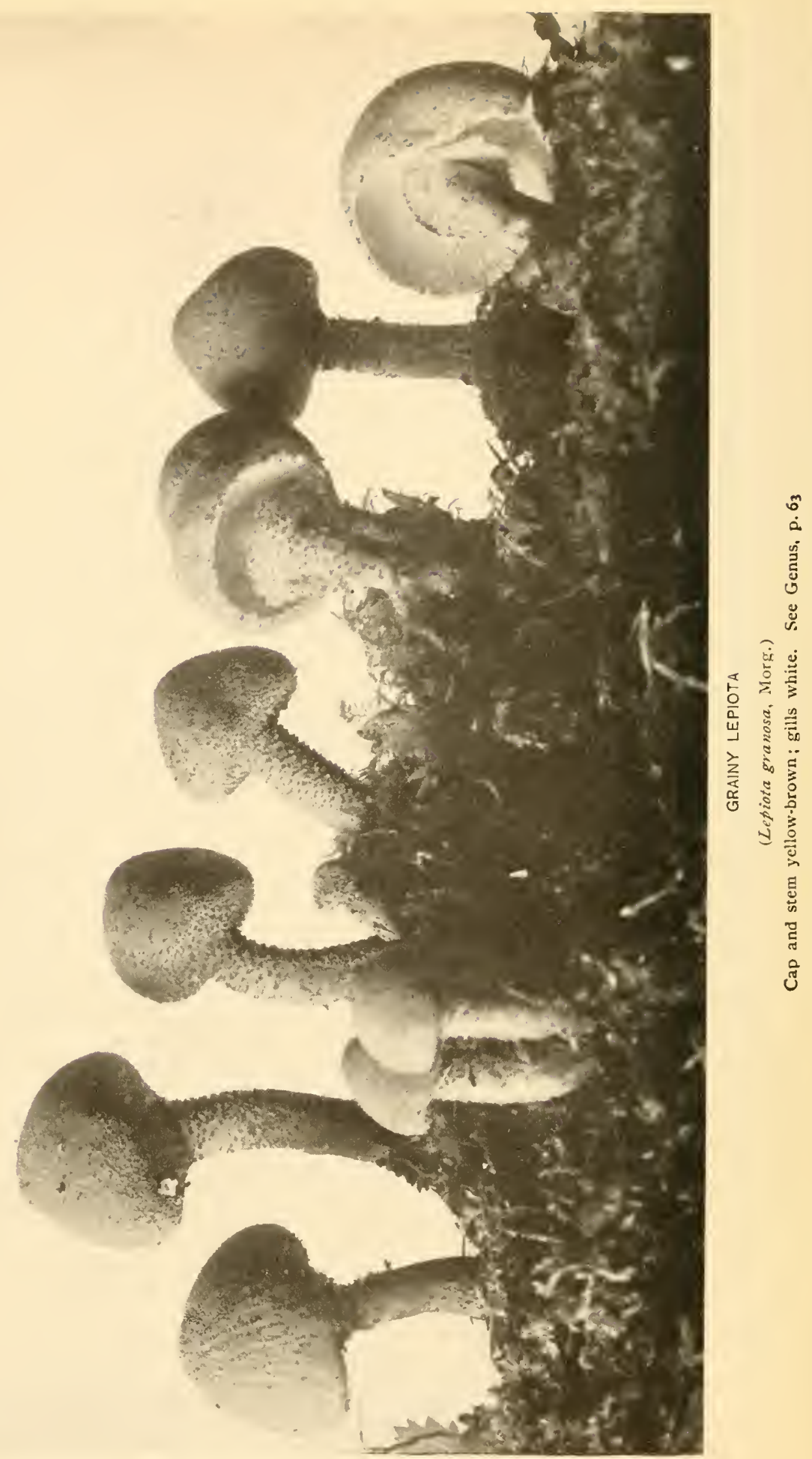


It is to the luminosity of these mycelial threads, which permeate the decaying wood, that the weird phosphorescent light in dense woods is due.

\section{GENUS LEPIOT $A$ (See Plate facing Page 64)}

The members of this genus have the gills free from the stem, and have no wrapper remains at the base of the stem. In some species the cap or pileus has the surface scaly, owing to the rupture of the fibres which compose it. It is this feature which has suggested the name Lepiota, from the Latin word lepis-a scale. There are about thirty species represented in the United States, of which a few are commonly eaten.

\section{Parasol Mush-} room; Tall Lepiota (Edible)

Lepiota procera

Cap or Pileus-Convex, like an open umbrella. Thin, umbonate, covered with closely pressed scales. 3-5 inches broad.

Stem or Stipe-Long, hollow, or with cottony pith ; bulbous at the base ; usually covered with closely pressed scales. $\quad 5^{-10}$ inches long.

Veil or Ring-Thick and firm ; often movable on the stem.

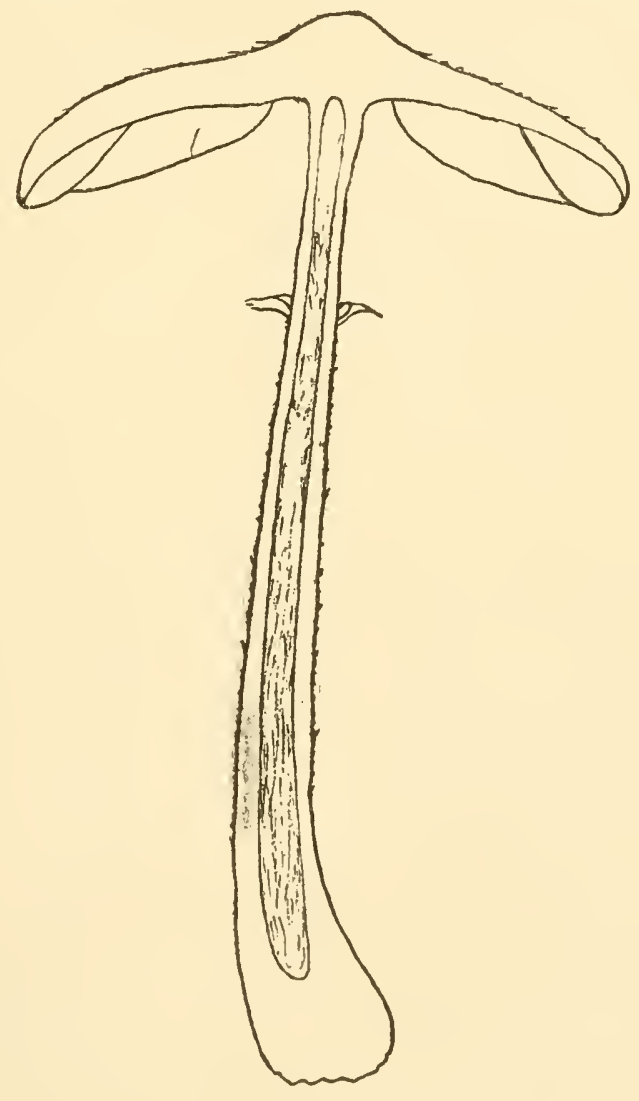

Section of L. procera

Lěp-Y-ōo-ta 'rōộ'-ě-ră 
Gills or Lamella-Closely placed, side by side. Whitish, or tinged with yellow. The inner extremity remote from the stem.

Spores-White, elliptical.

Flesh-White, soft, and dry.

Time-July to September.

Habitat-Thin woods, pastures, and by roadsides.

The specific name, Procera, from the Latin procera (tall), refers to the length of the stem.

There is no poisonous species for which it can be mistaken if one bears in mind that it has a long stem with bulbous base, a brownish, spotted cap with dark apex, and a broad basin about the insertion of the stem.

\section{Smooth Lepiota (Edible)}

\section{Lepiota naucinoides}

Cap or Pileus-Smooth, white ; rarely the central part of the cap is tinged with a smoky hue. 2-4 inches broad.

Stem or Stipe-Coloured like the cap; thickened at the base. Hollow or webby. 2-3 inches long.

Veil or Annulus-White. External edge generally thicker than the inner; often movable on the stem.

Gills or Lamelle-White when young; when old, pinkish or smoky brown. Rounded at the inner extremity and not attached to the stem. Narrower toward the stem than in the middle.

Spores-White, sub-elliptical.

Flesh-Thick, white, and tender.

Time-August-November.

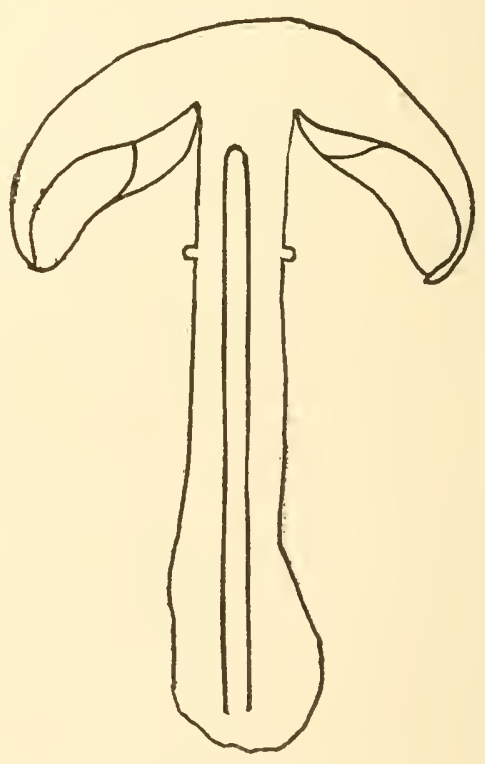

Section of $\mathrm{L}$. naucinoides

The smooth lepiota resembles the chalk agaric (Agaricus cretaceous), which has brown spores, and the meadow mushNau'-ç̧n-oi'-dës 


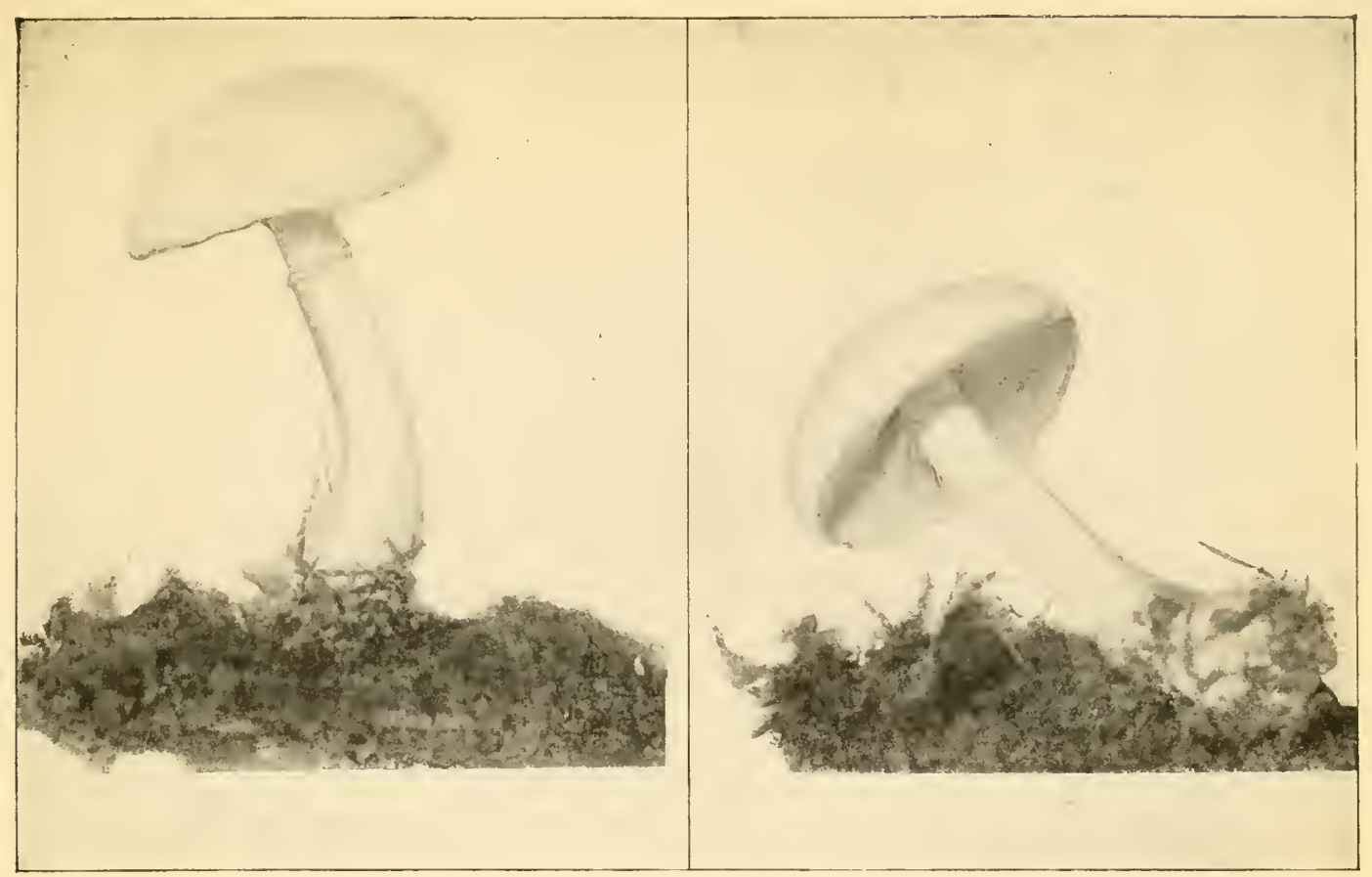

SMOOTH LEPIOTA (EDIBLE)

(Lepiota nancinoides, Peck)

Nat. size : Cap diam., $3^{1 / 2}$ inches; stem length, $4^{1 / 2}$ inches.

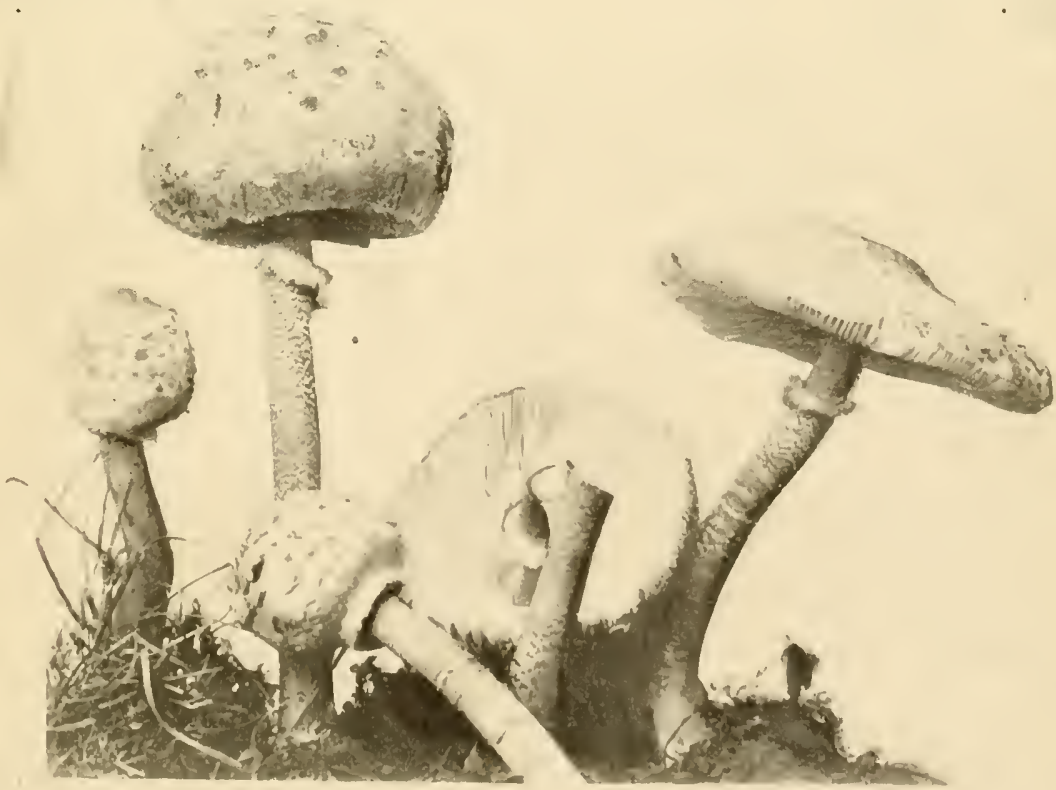

PARASOL MUSHROOM. TALL LEPIOTA (EDIBLE)

(Lepiota frecera, Scop.)

Nat. Size: Cap I lian.. $3^{1 / 2}$ inches; stem length, $+1 / 2$ inches Sep pape 63 




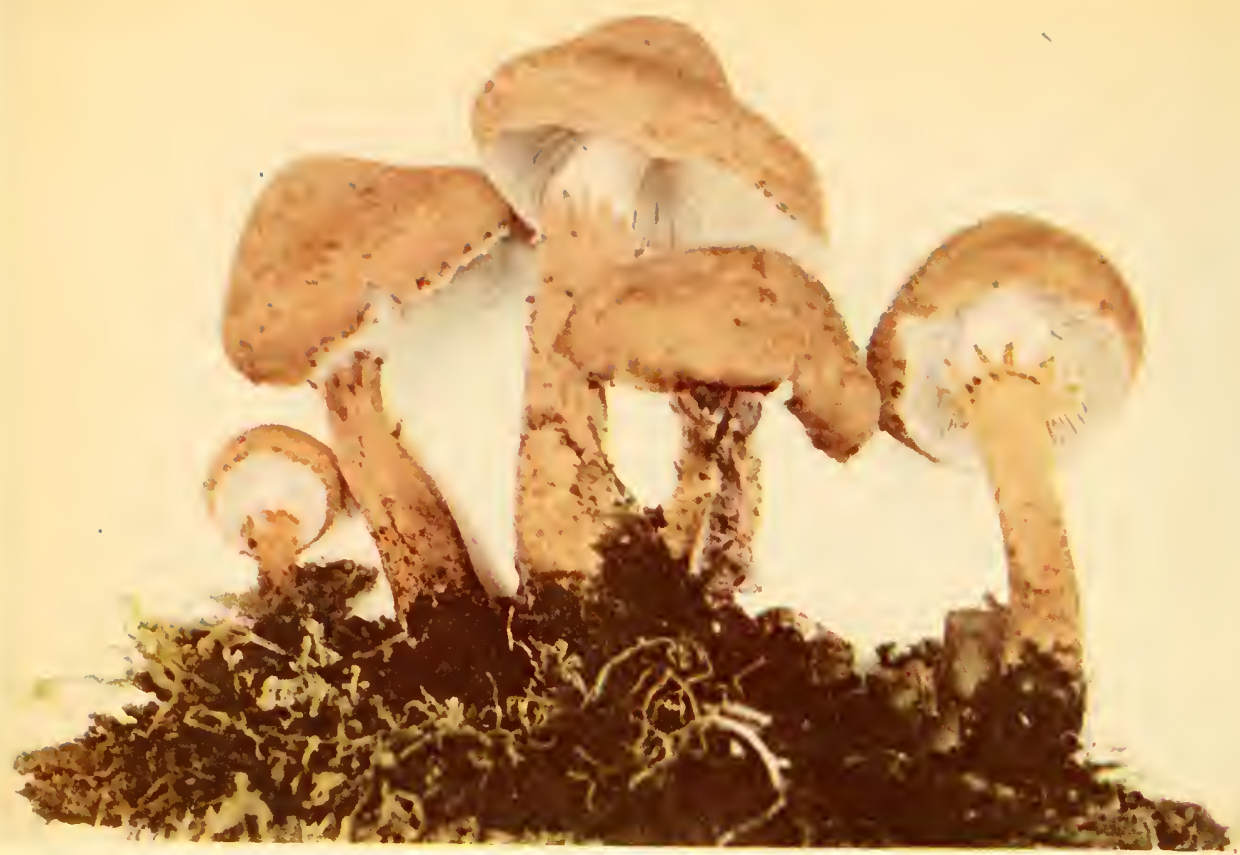

Lepiota Friesii, Lasch. (edible).

See page 65.

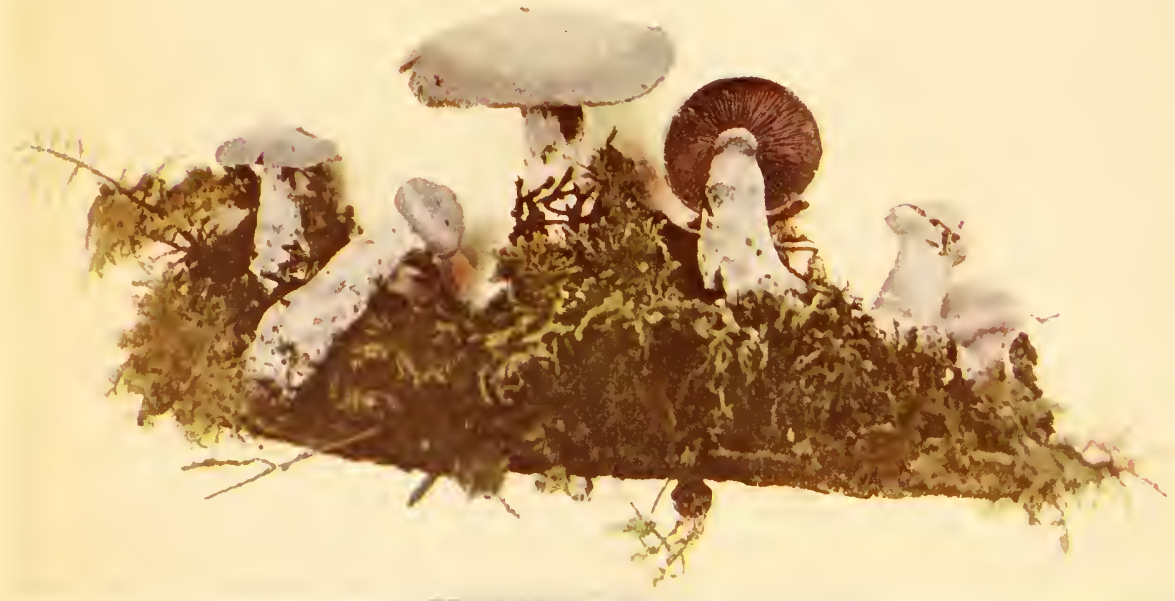

Cortinarius alboviolaceus, Fr.

Reduced. See page 86 . 
room (Agaricus campestris), which has darker gills, a persistent collar, and a stem tapering at the base. No harm can come from confusing these for edible purposes. Great care should be taken to be sure that a specimen thought to be a smooth lepiota has no volva or wrapper at the base, for the absence of a volva is the most marked difference between it and the poisonous vernal amanita (Amanita verna). The gills of the smooth lepiota turn a dingy brown or pink, and those of the vernal amanita remain white; and the cap of the smooth lepiota has not the moist smoothress and the brilliant whiteness of the vernal amanita.

\section{Lepiota Friesii}

Cap or Pileus-Rather thin, convex, or nearly plain, with soft, tawny fibres forming small patches over the surface. 1-4 inches wide.

Stem or Stipe-Tapering toward the cap, slightly bulbous at the base. The lower part of the stem coloured like the cap, and with similar fibrils. Hollow. Powdery white above the ring. $2-5$ inches long.

Ring or Anmulus--Present and pendulous.

Gills or Lamella-Narrow, crowded, free from stem ; white ; some forked.

Spores-White.

Flesh-Soft, white, with a slight odour when bruised.

Ring or Annulus-Well developed, drooping. White above, and tawny or scaly below.

Habitat-Soft, loose soil in bushy places.

Time-July to September.

\section{GENUS MARASMIUS}

The genus Marasmins belongs to the white-spored series. The plants are small, and wither and shrivel in dry weather, to revive again when wet. The gills are thin, and have acute edges.

The generic name comes from the same Greek word as the word marasmus, the name applied to a disease from which the patient wastes away without any apparent cause. The significance of the name will be apparent to one who watches the fleshy little plant shrink away when the sun shines.

$$
\text { Frē'-sI-i }
$$

;
Mă-răs'-mı-uัs 


\title{
Fairy-ring Mushroom (Edible)
}

\author{
Marasmius oreades
}

Cap or Pileus-Fleshy, tough, smooth, convex, or nearly plane, often with the centre higher than the space between it and the rim. Reddish; fading, as it ages or dries, to pale yellow or buff. 1-2 inches broad.

Gills or Lamella-Broad and wide apart, creamy or yellowish, rounded at the stem end, unequal.

Stem or Stipe-Whitish, slender, tough, solid, coated with dense woolly hairs. $1-2 \frac{1}{2}$ inches long.

Ring or Annulus-None.

Spores-White.

Flesh-Thin, white, tough.

Time-May to October.

Habitat-In circles or groups.

Dangerous fungi somewhat resembling the $M$. oreades, ard found in company with it, may be distinguished by their darkcoloured spores.

\section{GENUS COLLYBIA}

The members of this genus have white spores, and the lamellæ with thin edges attached to the stem by their inner extremity. The stem has a cartilaginous rind; that is, it is hard and of a tough texture. The genus contains fifty-four American species, some of which are regarded as edible, while others are regarded as deleterious. The velvet-stemmed collybia, or Collybia velutipas, is edible, and remarkable for its habit of growing long after the frosts of winter have come. It is easily recognised by its yellowish and viscid cap, and its habit of growing in tufts, and developing on the stem a dense coat of velvety hairs. The rooted collybia, Collybia radicata, may be recognised by the character of its stem, as the lower part is like al slender tap root, generally penetrating the earth to a depth equal to the length of the stem above the surface.

$$
\text { Ō-rẽ'-ă-dēs CØ̌l-ly̆b'-1-ă }
$$




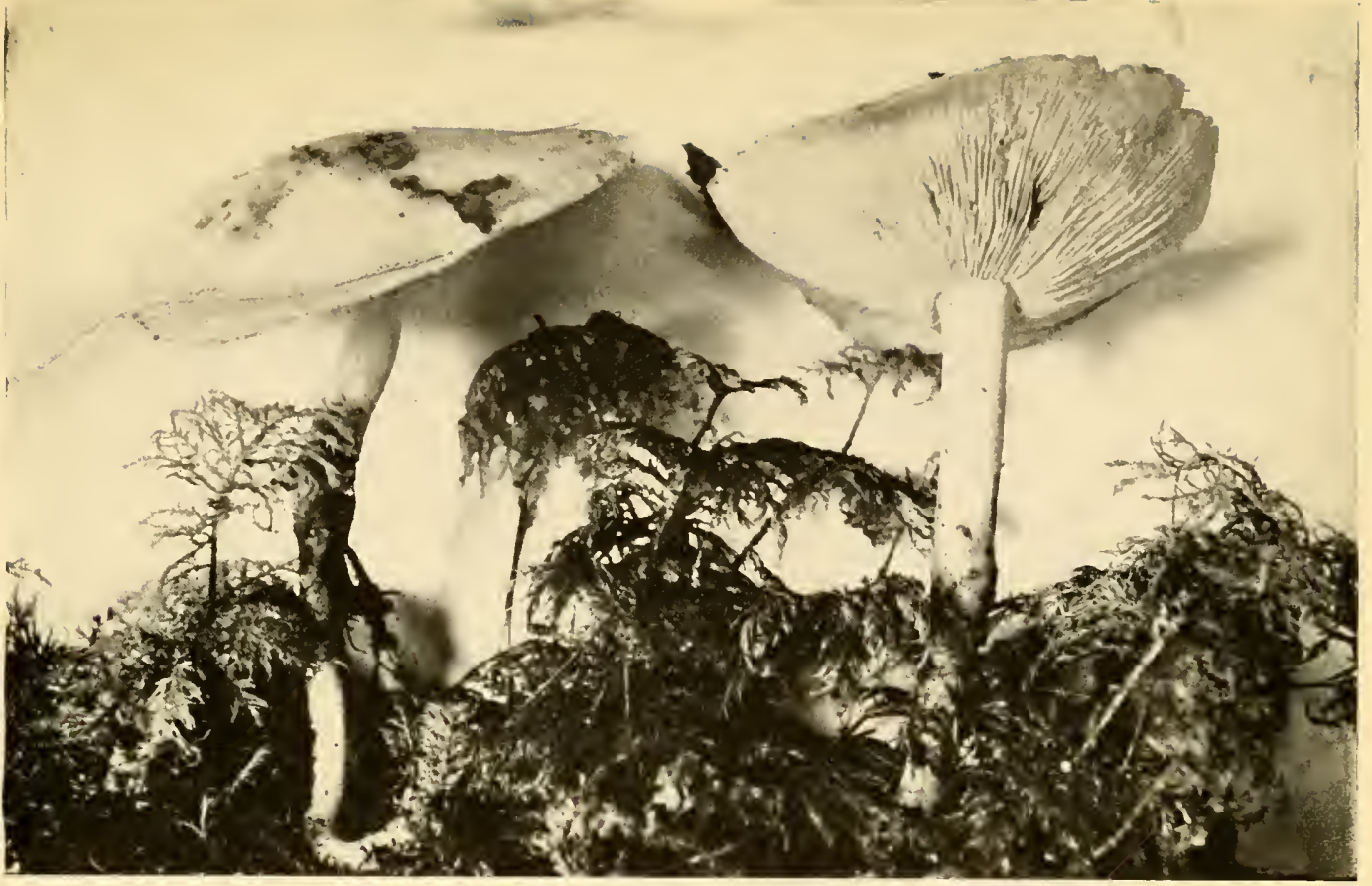

SPOTTED COL.LYBIA (EDIBLE, MCl.)

(Collybia maculata, A. \& S.)

Cap and stem white with rusty spots; gills white. See Genus, p. 66

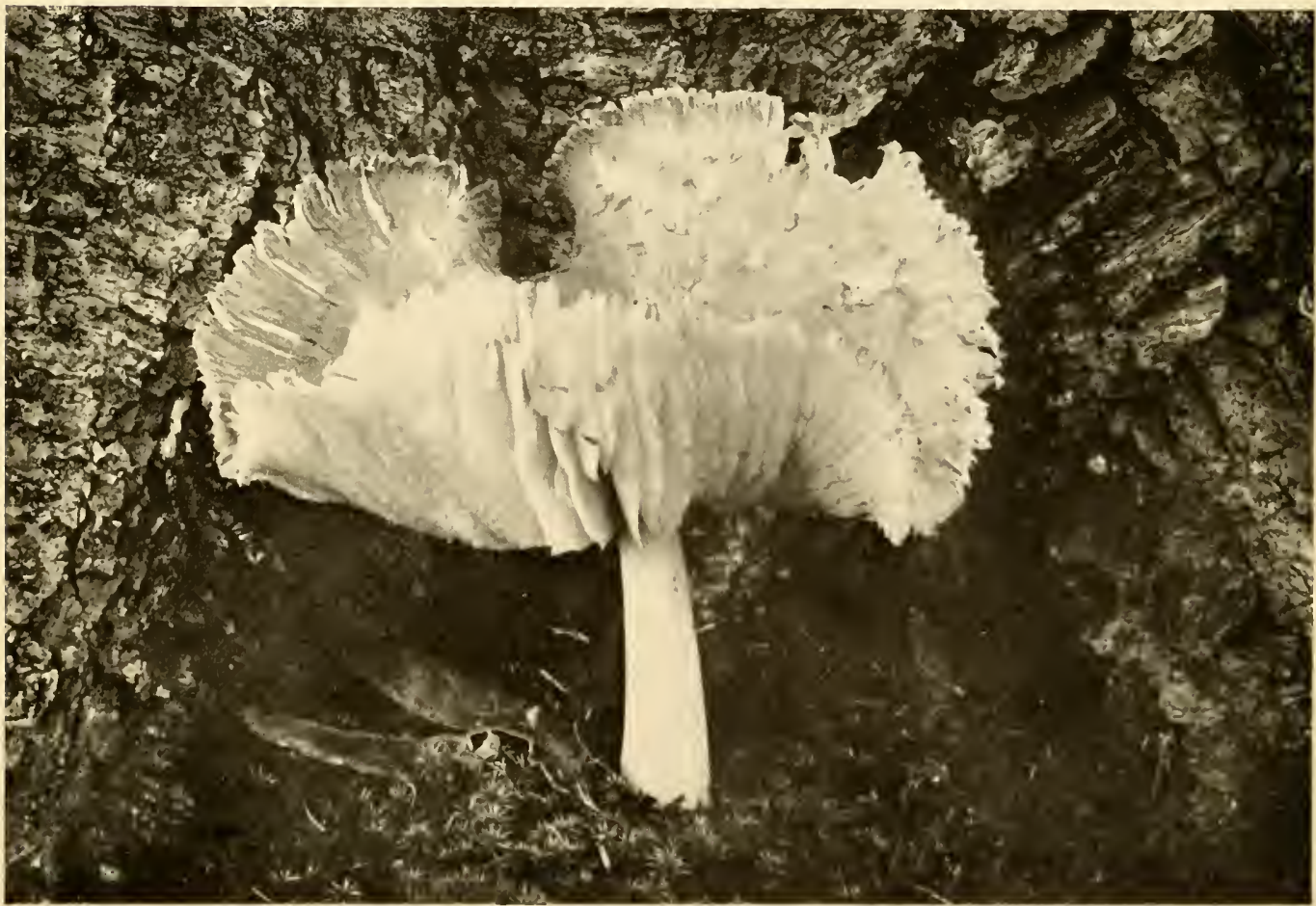

BROAD-GILLED COLLYBIA (EDIBLE, MCl.)

(Collybia flatyphylla, Fr.)

Surface of cap brownish, fibrillose; gills white. See Genus, p. 66 




\section{Collybia familia (Edible)}

Cap or Pileus-Greyish, with centre darker. Smooth margin, often cracked. Slightly striate.

Gills or Lamella-Slightly greyish, soft, unequal, free, not crowded.

Stem or Stipe-Greyish, hollow. Lower part covered with white woolly substance.

Spores-White.

Flesh-Greenish grey.

Time-September.

Habitat-The specimen photographed was

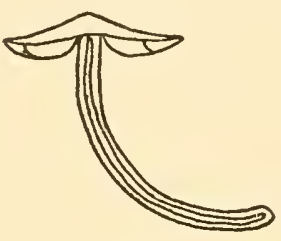

Section of C. familia

found growing upon a prostrate evergreen tree near Lake Placid.

\section{GENUS PANUS (See Plate facing Page 145)}

The members of this genus are leathery plants, with the stems lateral or wanting. The gills are simple, not forked, and the spores are white. Panus stypticus is common on rotten wood, and gives out a weird, phosphorescent light.

The species of the genus Panms so much resemble species of the genus Lentinus, which do not have toothed margins, that Panus and Lentinus are considered by some as one genus, with the name Lentinus.

\section{GENUS TROGIA}

But one American species is reported, this is small and leathery, brownish in colour, with the spore-bearing surface white. The lamellæ are obtuse on their edges, and are not hairy. The spores are white. This plant is common on fallen branches of the alder.

\section{GENUS SCHIZOPHYLLUM}

The members of this genus have white spores and a leathery pileus, with the lamella hairy and grooved, or split. Schizophyllum commune is common on twigs or branches. It varies from $1 / 2$ to 2 inches across, appearing ats fluted shells on the bark.

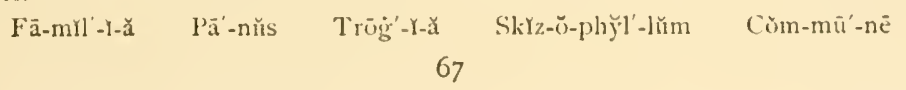


Fungi with Gills

\section{GENUS OMPHALIA}

The members of this genus have white spores, and the gills growing down on the stem. They have a hard, tough rind to the stem, which distinguishes them from the genus Clitocybe, which has fleshy stems. Omphalia umbellifera is a small species, with a cap about an inch broad. It is the common mushroom on the top of Mount Marcy, the highest mountain in the State of New York.

\section{GENUS RUSSULA}

The genus Russula may usually be recognised by its brittle character, added to its fleshystem and the fact that the lamellæ are usually joined to the stem. Bright clear reds and purplish hues prevail, but several species exhibit a green colour, or an approach to green. The spores are white or yellowish, and the flesh never exudes a milky or coloured juice.

\section{Emetic Russula (Dangerous)}

\section{Russula emetica}

Cap or Pileus-Rosy tint to rich red. Flesh thin. The margin

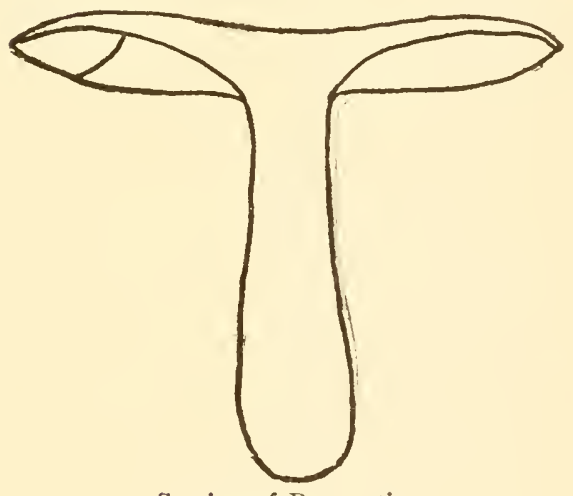

Section of R. emetica

furrowed with parallel lines. Skin separable, somewhat viscid. Cap diameter of specimen photographed, $3^{\mathrm{T}} / 2$ inches.

Gills or Lamella-White. Usually uniform, occasionally unequal; broad and brittle.

Stem or Stipe-Rosy. Swollen near the base. Specimen photographed, $2 \frac{1}{2}$ inches long.

Spores-White.

Flesh-White, unless just under the skin, where it may be pink.

Very fragile. Peppery to the taste.

Ŏm-phā'-1Y-ă Ŭm-běl-1Y'-fěe-ră Rŭs'-sŭ-lă Ě-mět'-Y-că 


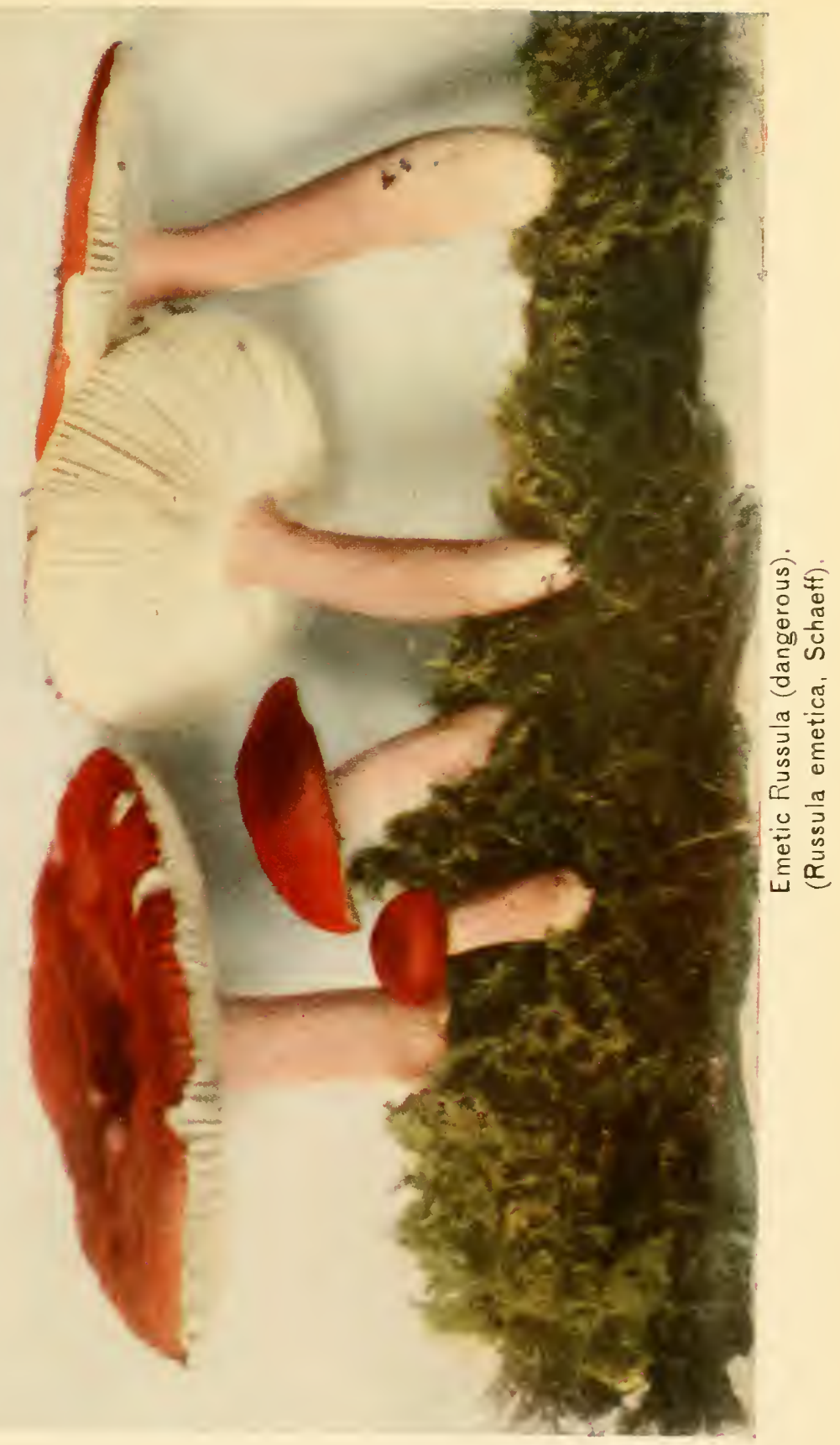






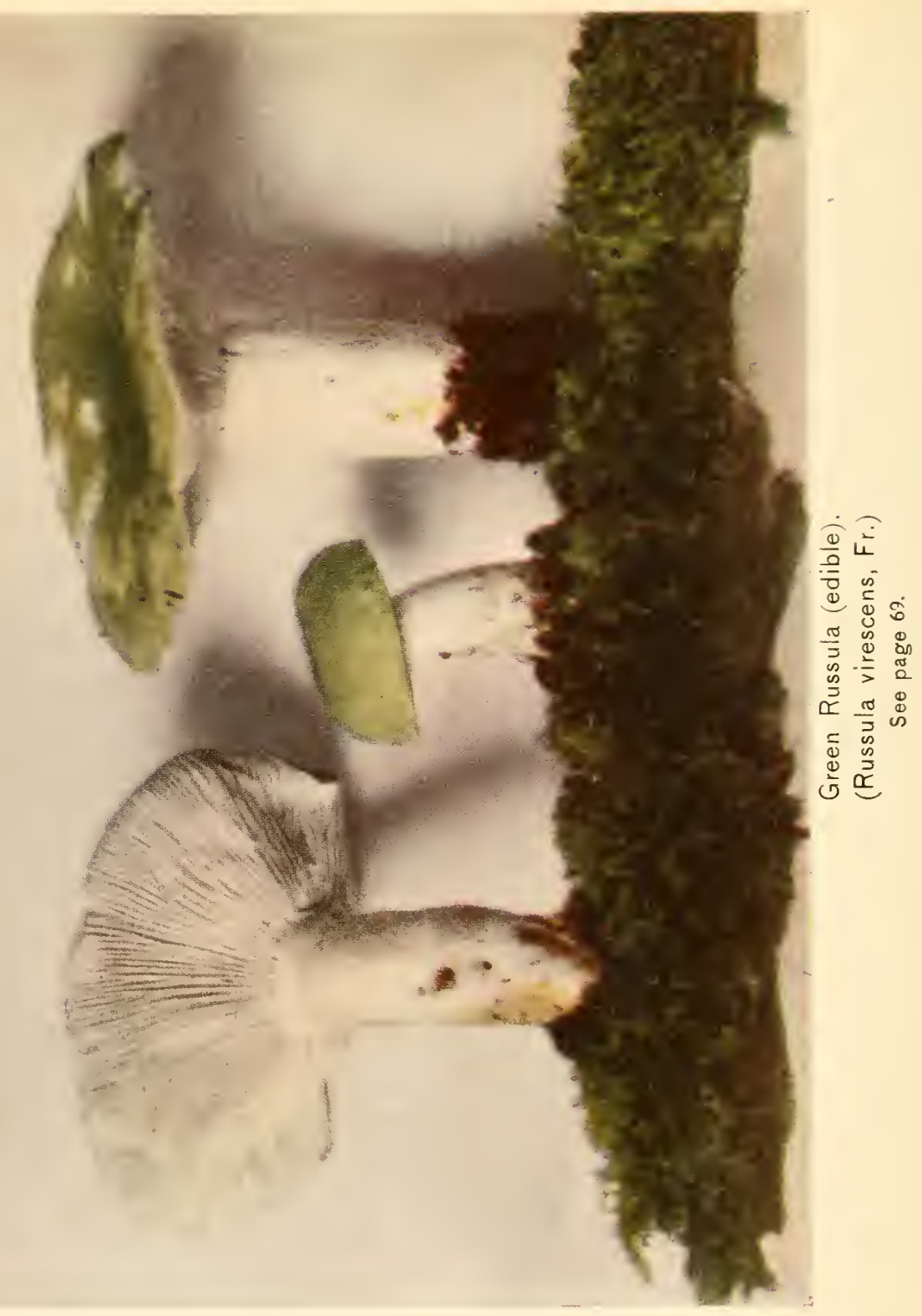


Taste-Acrid and biting.

Time-July to November.

Habitat - In damp meadows, in woods, in grassy places, under pine trees and firs.

\section{Green Russula; Verdette (Edible)}

\section{Russula virescens}

Cap or Pileus-Greyish green. At first globose, then expanded; convex or depressed at the centre. Firm and dry. Not viscid, but adorned with flaky greenish or yellowish patches, produced by the cracking of the skin. 2-4 inches broad. Margin marked with impressed lines.

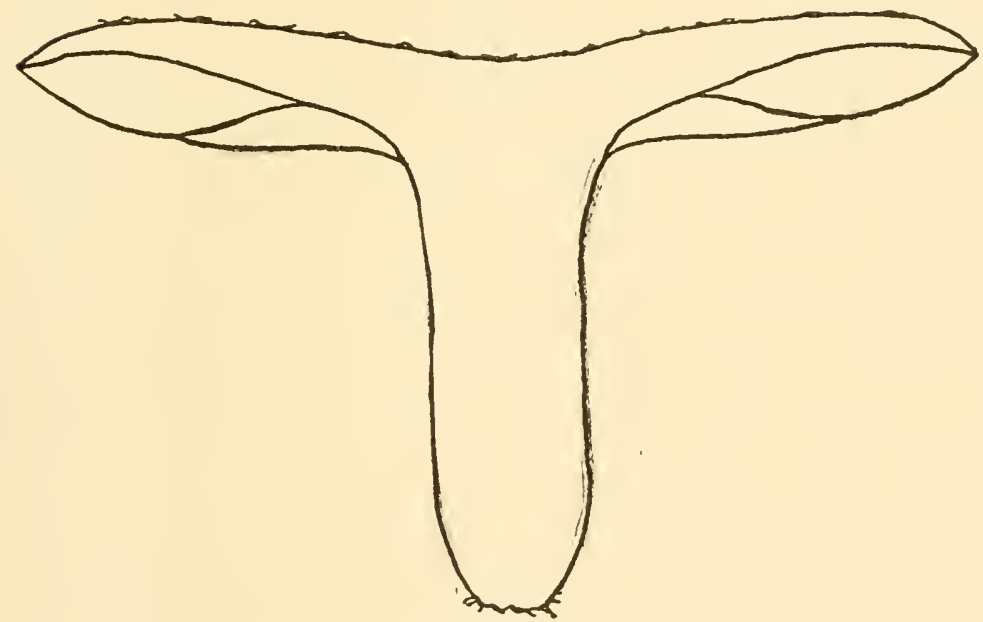

Section of $R$. virescens

Gills or Lamelle-White. Moderately close ; free, or nearly so ; narrow as they approach the stem. Some forked, others not.

Stem or Stipe-Shorter than the diameter of the cap. Smooth, white, and solid, or somewhat softer within. $1-2$ inches long.

Spores-White, rough, nearly globose.

Flesh-White; mild in taste. 
Time-July and August.

Habitat-Grassy grounds, groves, and open woods.

No milky nor coloured juice, no coloured circular zones.

\section{Variable Russula (Edible)}

\section{Russula heterophylla}

Cap or Pileus-Variable in colour. Greenish or pinkish grey, but

fleshy, firm ; slightly convex, then depressed; smooth, and polished, the very thin skin disappearing. Margin thin, smooth, or with slightly depressed lines closely placed.

Stem or Stipe-Solid, firm, smooth, shining white, the apex occasionally dilated in the form of a cup.

Annulus or Volva-None.

Gills or Lamella-Narrow, crowded, forked ; white ; of different lengths.

Spores-White.

Flesh-White; mild in taste.

Habitat-Woods. Common.

Time-July to October.

The specific name refers to the difference in the lengths of the gills.

\section{GENUS CLITOCYBE}

The members of the genus Clitocybe have the spores white, no volva nor annulus, the gills with thin edges not notched on the edge near the stem, and generally decurrent.

\section{Clitocybe laccata (Edible) (See Plate Facing Page 67)}

Cap or Pileus-When moist, pale red, buff red, or flesh red; when dry, greyish to pale yellowish brown. Surface covered with tiny tufts of hair. Convex when young, flattened with wavy margin when old ; often depressed. $1 / 2-2$ inches broad.

Gills or Lamella-Broad, distant, unequal. Flesh colour. Slightly decurrent.

Veil and Annulus-None.

Stem or Stipe-Slender, stiff, fibrous, stuffed, or hollow. Colour like cap. Often twisted. 1-3 inches long.

Spores-White, rough, globose.

Flesh-Thin, pale flesh colour, leathery, tasteless.

Hět' ĕr-ŏ-phy̆l'-la.

Clī-tŏ-çy̆'-bè

Lăc-cā'-tă 


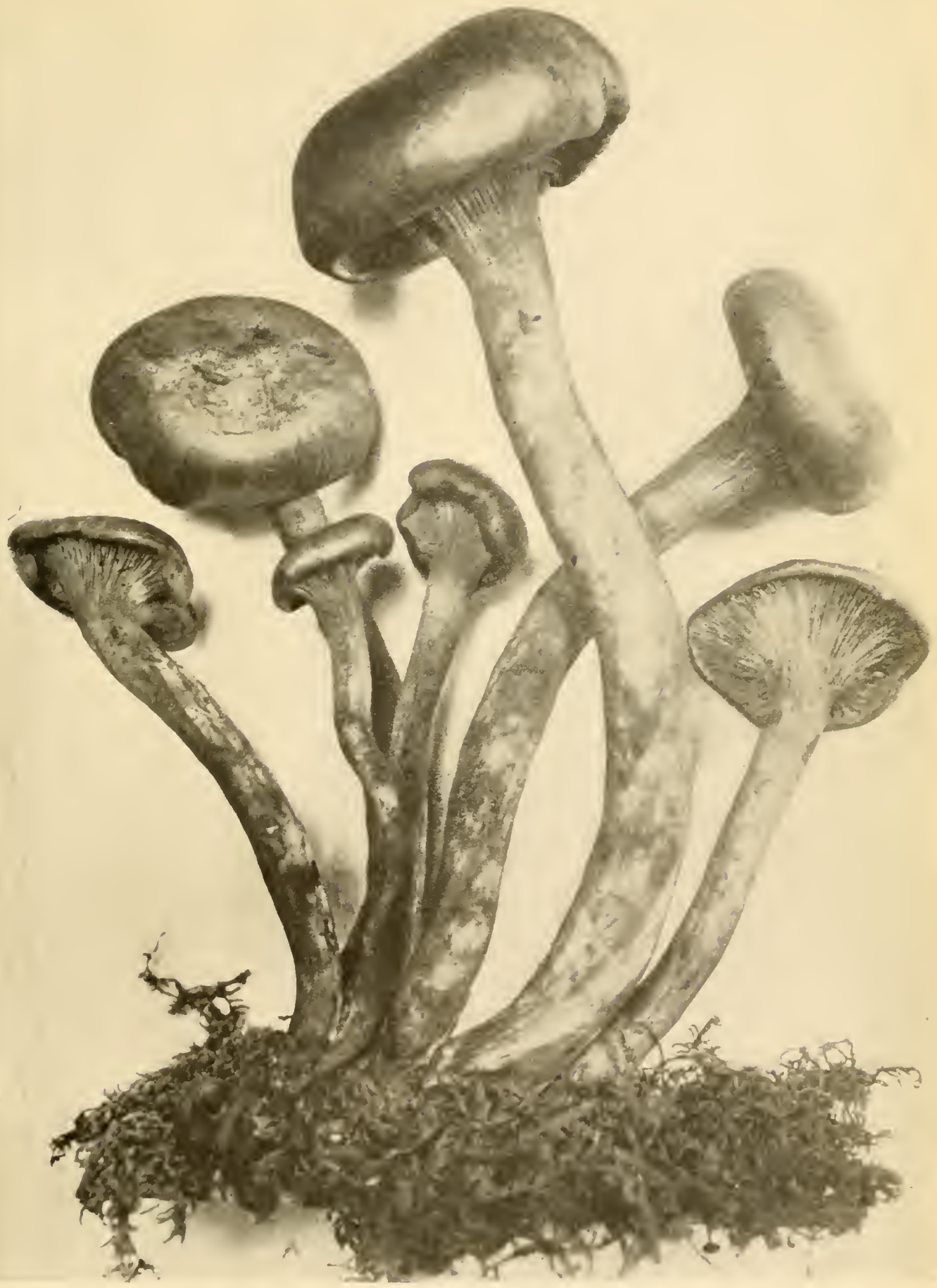

DECEIVING CLITOCYBE (UNWHOLESOME)

(Clitocybe illudens, Schw:)

Dull orange; phosphoreseent. See Genus, P. 70 




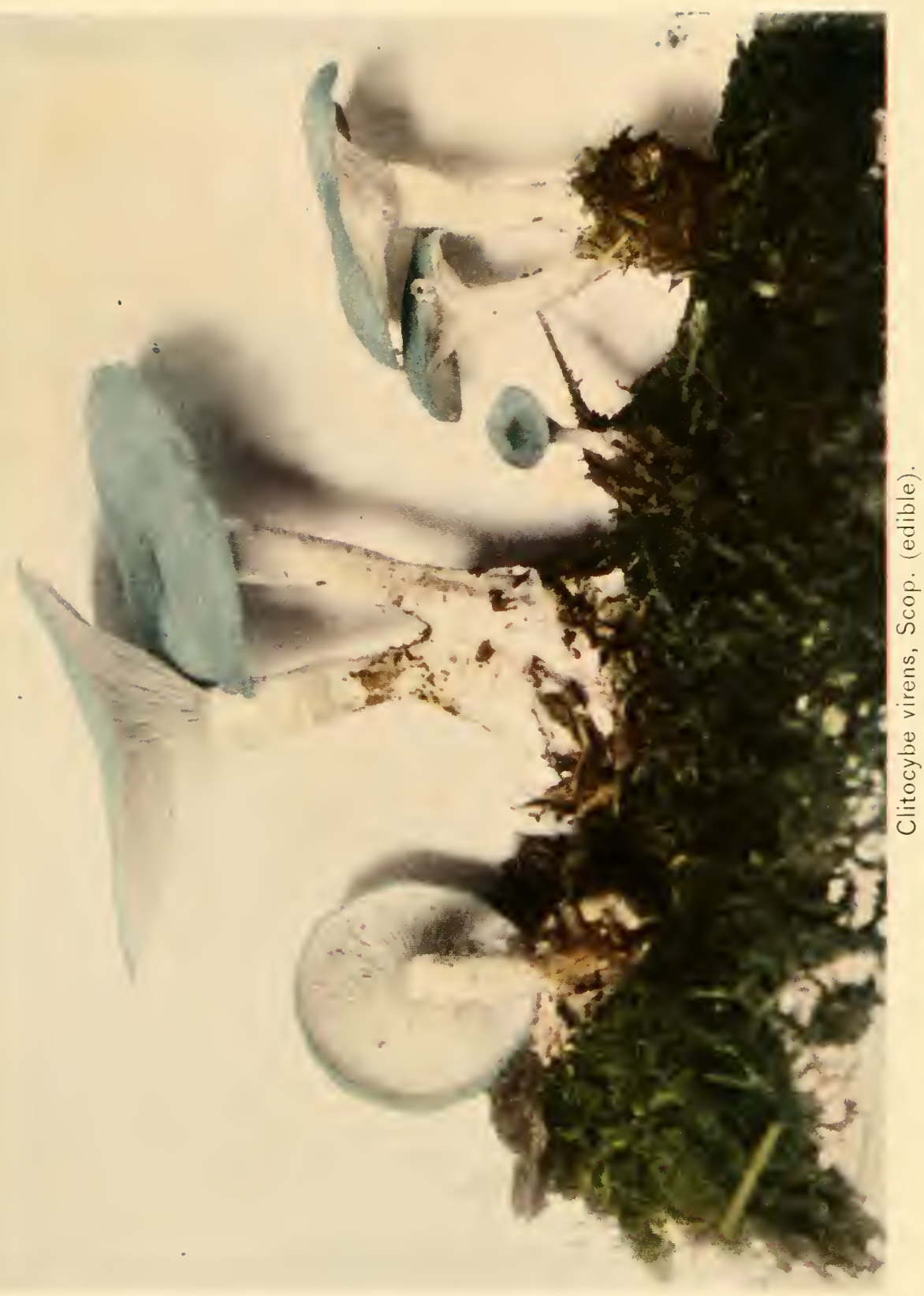




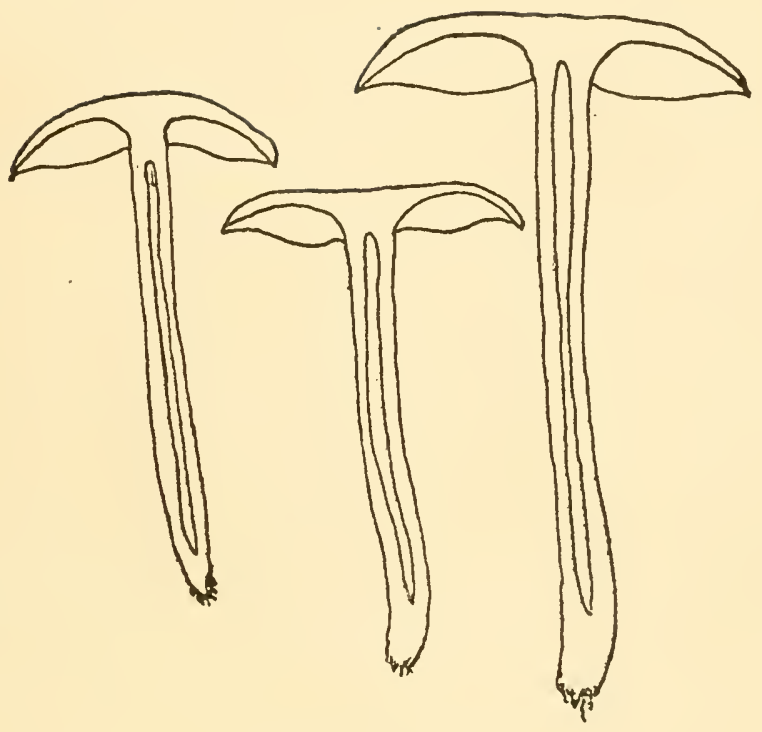

Sections of C. laccata

Time-Spring to autumn.

Habitat-Wood, swamps, or open fields, naked ground, mossy or grassy places.

Var. amethystina has cap darker, gills amethyst, quite decurrent.

Var. pallidifolia, gills paler than laccata.

Var. striatula, plants small, gills showing as lines through the thin cap.

\section{Clitocybe virens}

Cap or Pileus-Fleshy, convex, expanded, obtuse. Pale greenish blue.

Gills or Lamelle-White, crowded, thin, slightly decurrent.

Stem or Stipe-White, with occasional rusty spots; stiff, solid: Sometimes two stems are found growing together at the basc, Spores-White.

Flesh-White.

Time-Autumn.

Habitat-The specimen photographed was found growing in mixed woods in Pennsylvania.

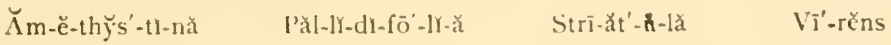




\section{GENUS TRICHOLOMA}

The members of genus Tricholoma have white spores, and no collar on the stem. The gills are attached to the stem, and are notched on the edge at or near the stem.

\section{Masked Tricholoma (Edible) \\ Tricholoma personatum (var. bulbosum)}

Cap or Pileus-Variable in colour; pale lilac, with yellowish tint; brighter in young specimens; sometimes whitish or pale greyish. Thick, fleshy, convex when young, with margin

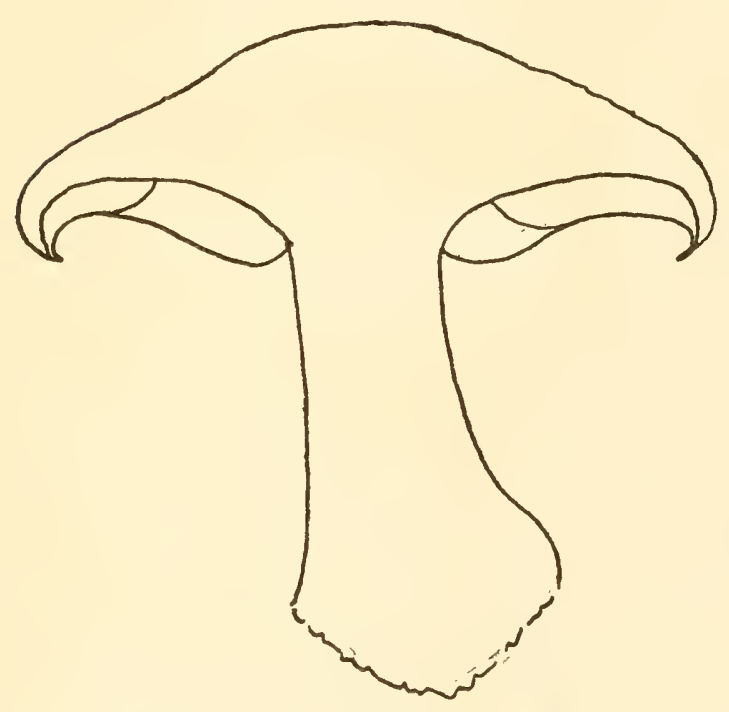

Section of T. personatum (var. bulbosum) rolled in, and slight bloom or mealiness on the surface. When mature, smooth ; margin wavy or turned upward.

Gills or LamellaFaint lilac colour, with tint of violet. Narrow, unequal, free, close, and rounded at the stem end.

Stem-Fain t lilac tint. Surface rather fibrous; short, stout, solid, bulbous.

Spores-Sordid white, ellipti.. cal.

Flesh-Firm.

Habitat-Thin woods, open grassy places. Time-September to freezing weather. 


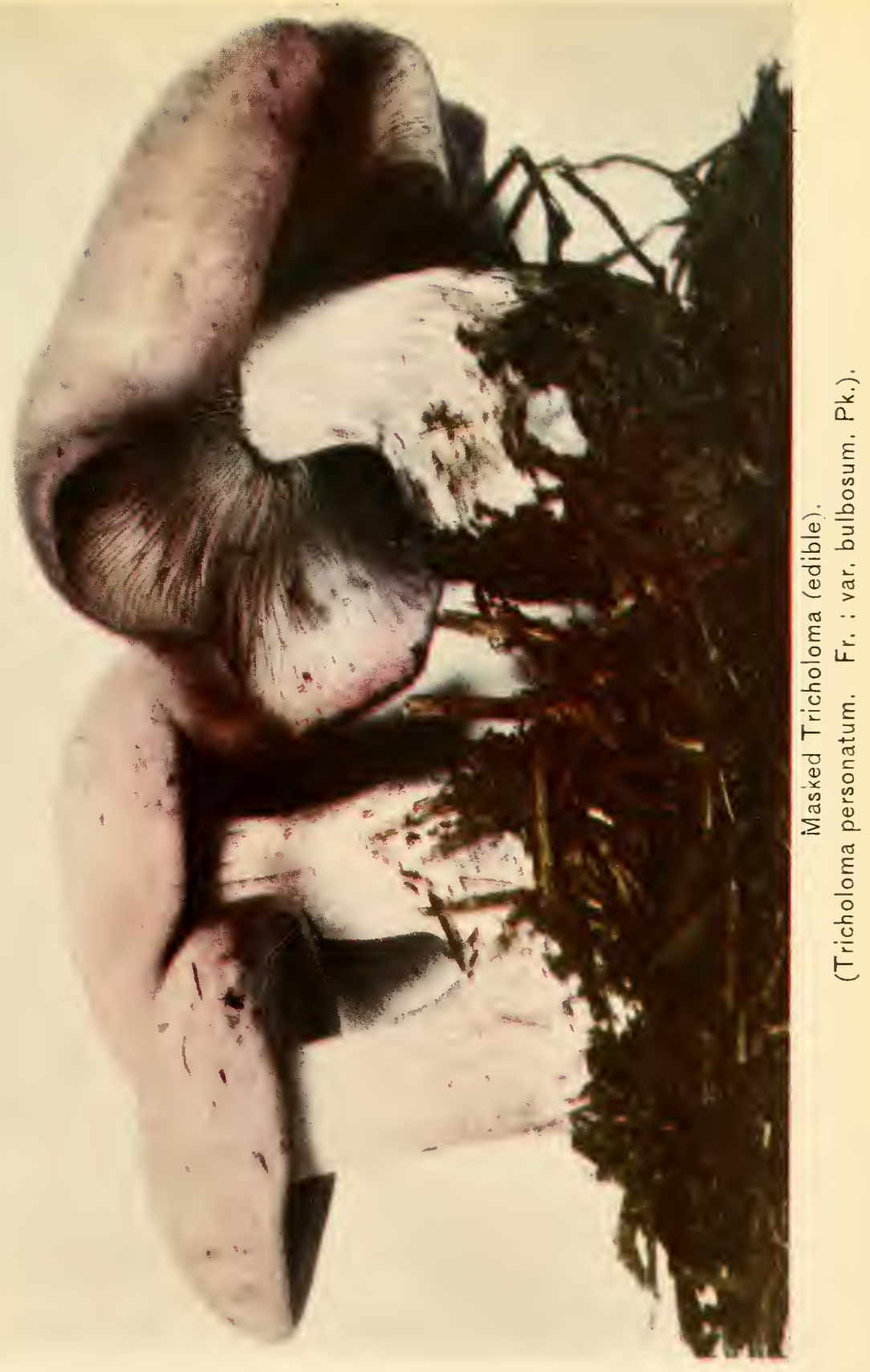






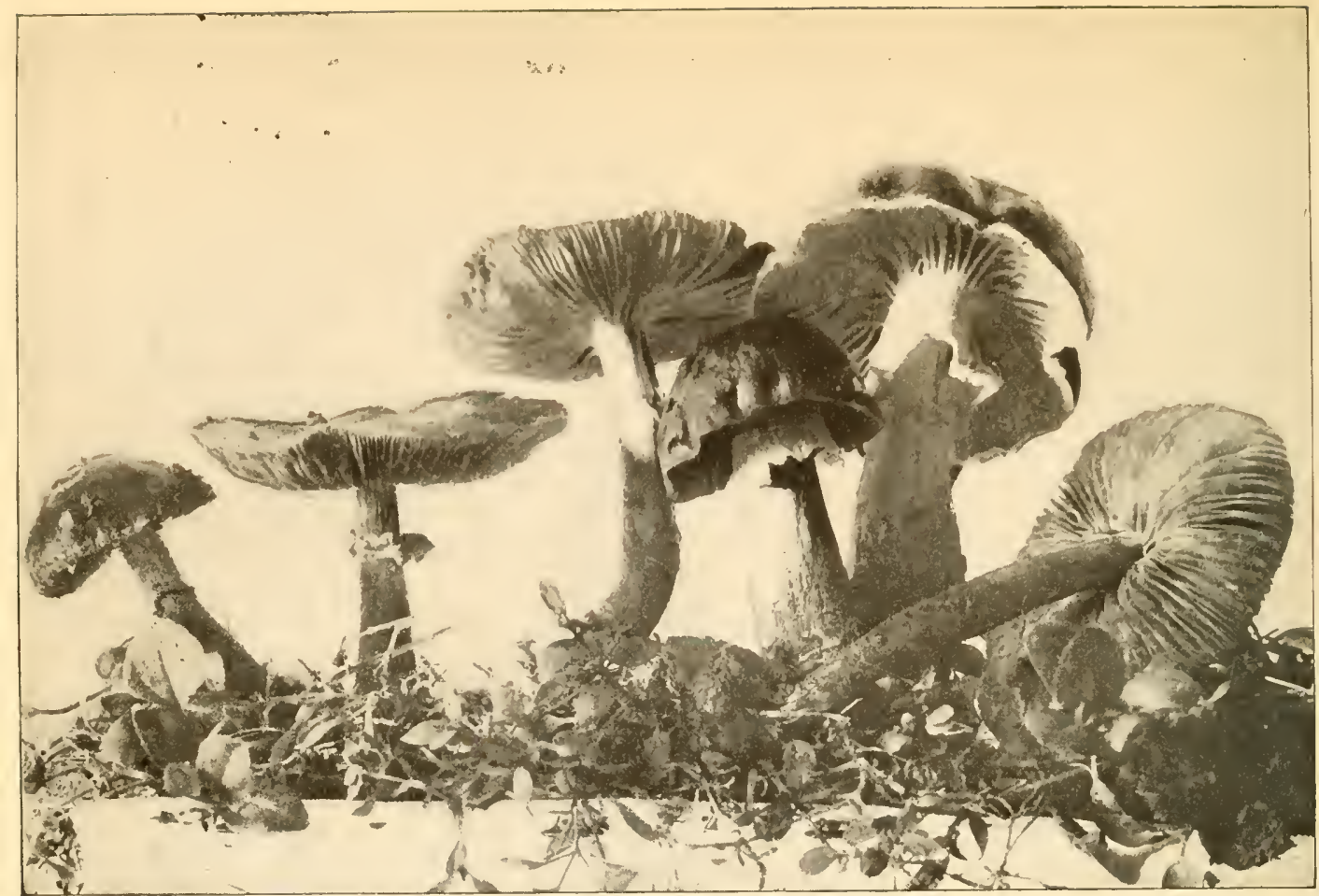

Pholiota aggericola, Peck

Reduced slightly

See page 84

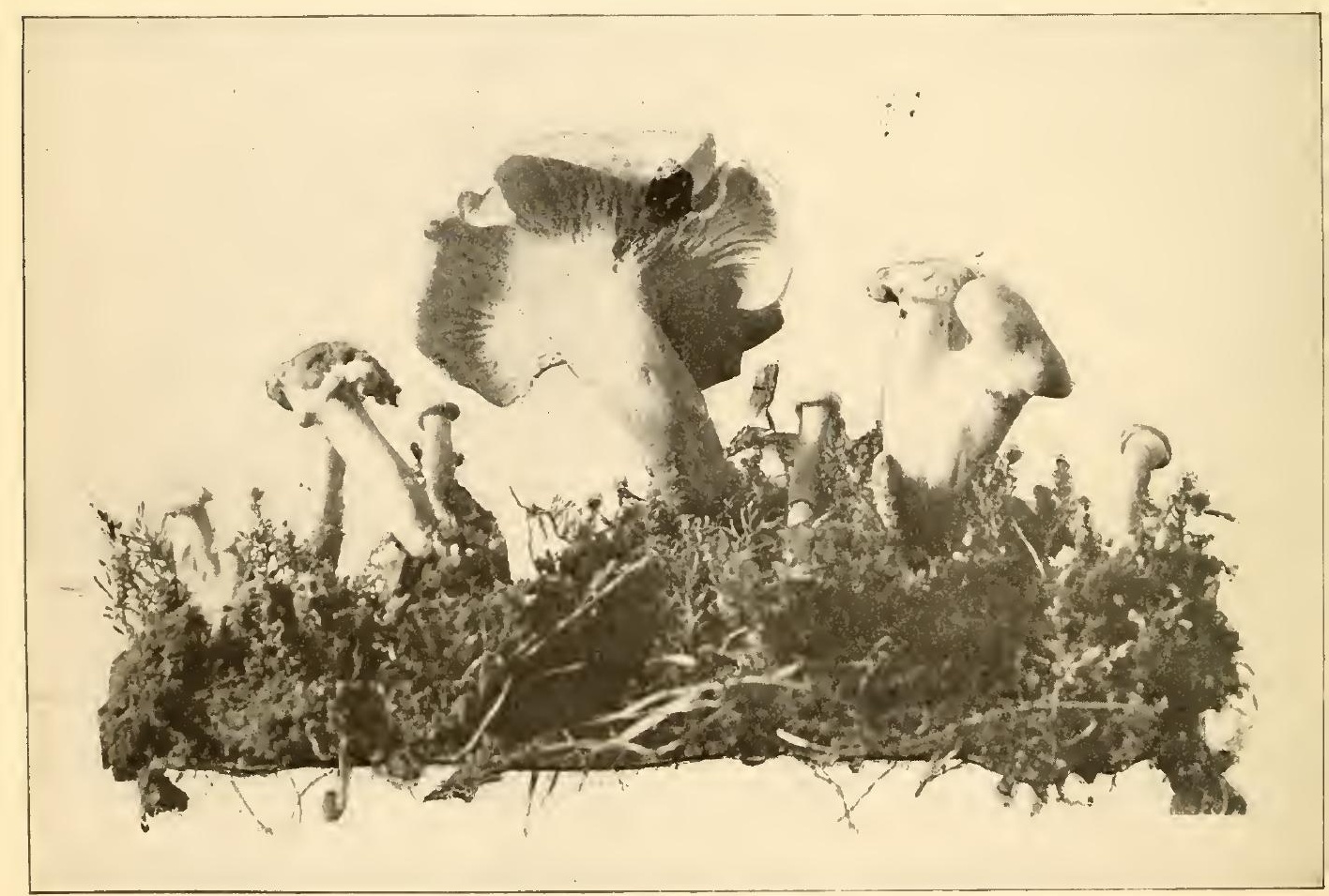




\section{Craterellus cantharellus (Edible)}

Cap or Pileus-Margin wavy. Yellow or pinkish yellow. Fleshy, firm, convex, then centrally depressed.

Gills or Lamella-Blunt, running down the stem, forking many times.

Stem-Solid, yellow, and smooth.

Spores-Yellowish.

Flesh-White, slightly stained in places. Taste slightly peppery; no odour.

Time-Summer and autumn.

Ilabitat-Specimen photographed was found growing in moss and earth on an old wood road in mixed woods, New Jersey.

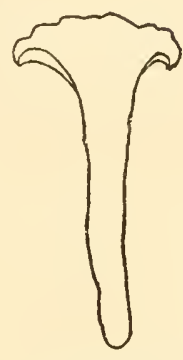

Section of C. cantharellus

Craterellus is at present classified as one of the family Thelephoracea. For convenience we have placed it under "Fungi with Gills." It is interesting, as it forms a connecting link between fam. Thelephoracese and fam. Agaricacece.

\section{GENUS AGARICUS}

The genus Agaricus includes all brown-spored species which have free gills and a stem with a collar. The distinctive features of several edible species may be quite satisfactorily seen by reference to the table with parallel columns.

Mushroom-growing is becoming quite an important industry in this country; both professional horticulturists and amateurs successfully engage in it. It is not a difficult matter to raise the common mushroom, as the conditions necessary are easily obtained. Mushrooms will grow almost anywhere out of doors. and also in cellars, caves, and tunnels where a uniform and moderate temperature of from $50^{\circ}$ to $60^{\circ}$ Fahr. can be maintained. The part of a cellar devoted to mushrooms must be darkened somewhat, must have a dry floor, and must be protected from wet overhead and from winds. These conditions are common in cellars which are rather dark, but sufficiently well ventilated not to be musty. The bed for the mushrooms is prepared in a manner

Crã'-těr-ěl'-lŭs.

Thčl-ē-phö-rä'-çě-ie 


\section{Fungi, with Gills}

similar to that employed in making a hot-bed, care being taken that the conditions are such that too great heat is not generated. Any one desiring to experiment will find it helpful to have the "Farmers' Bulletin," No. 53. "How to Grow Mushrooms," which may be obtained from the United States Department of Agriculture, Washington, D. C. 


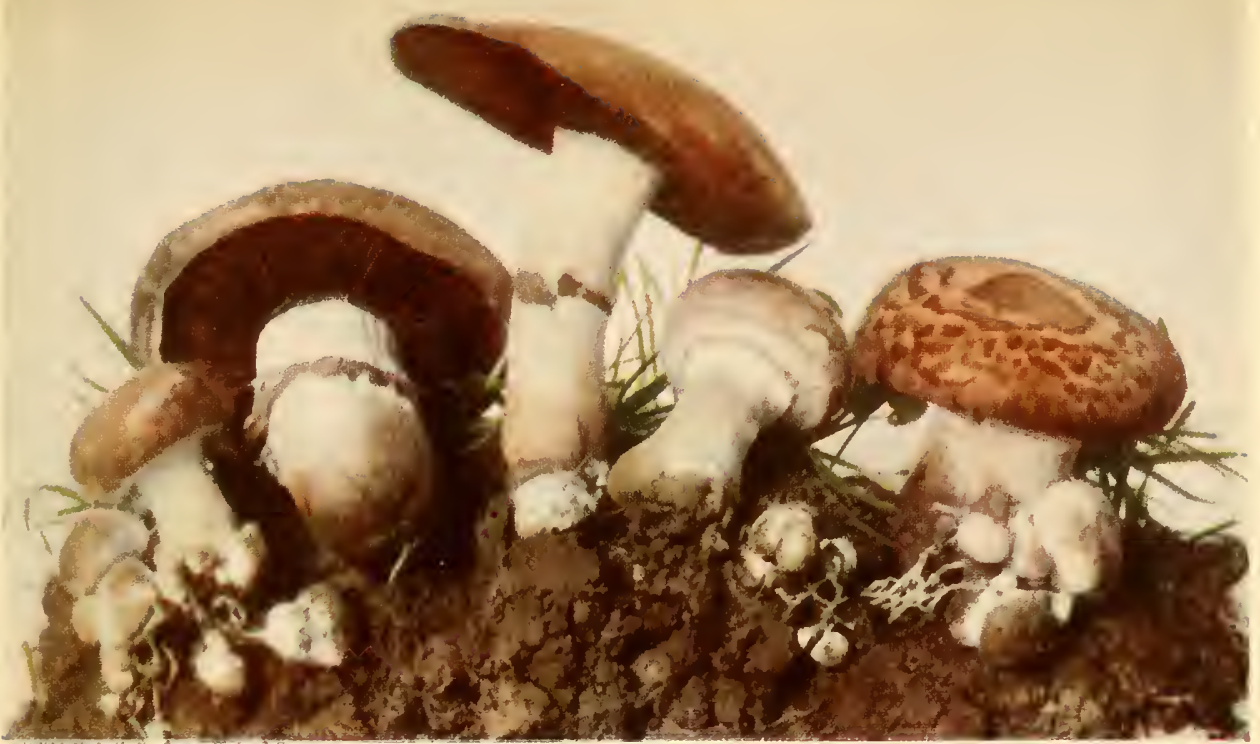

Agaricus campestri, L. (edible).

Reduced. See page 76.

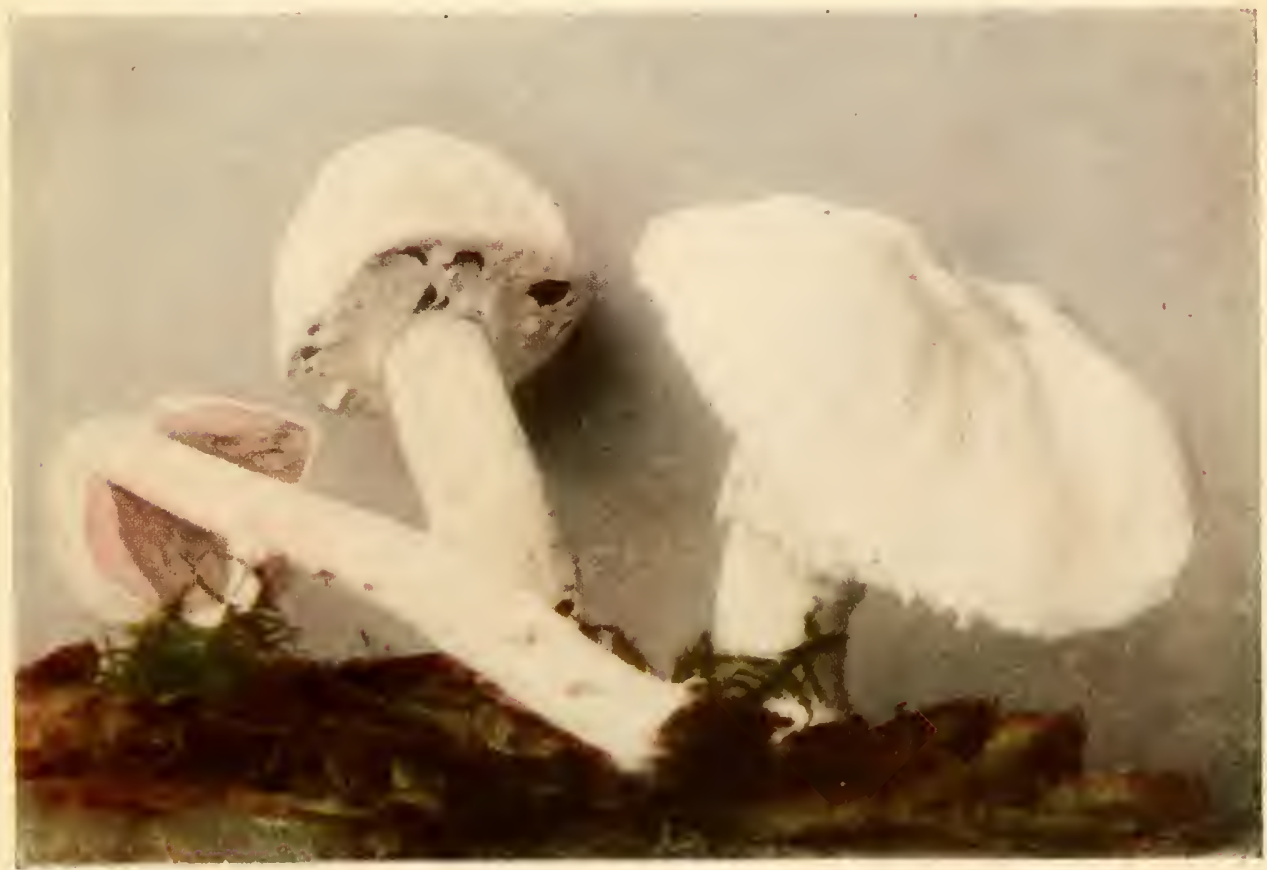

Agaricus abruptus, Pk. (edible).

Reduced. See page 77. 



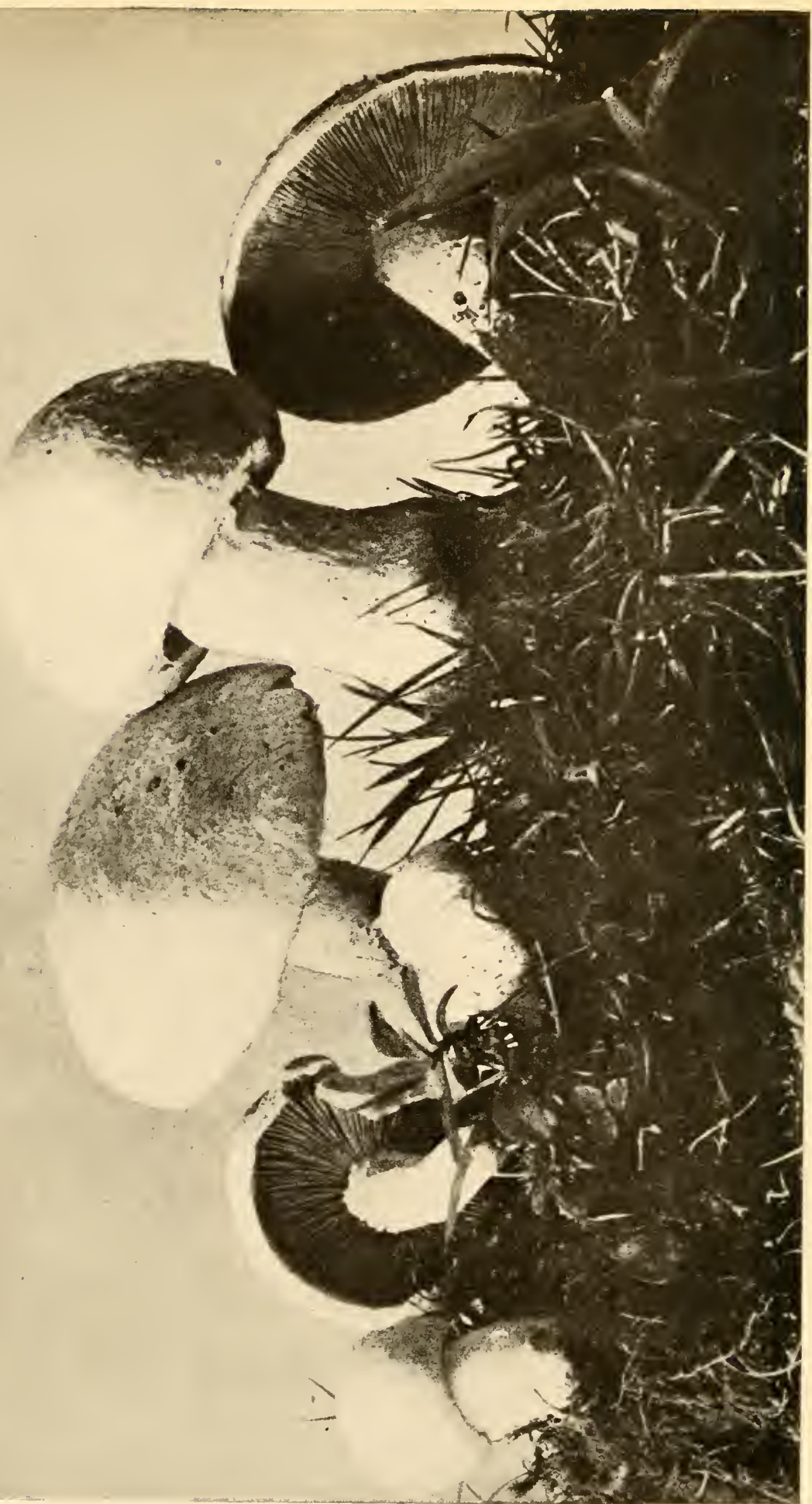
Brown-spored Series

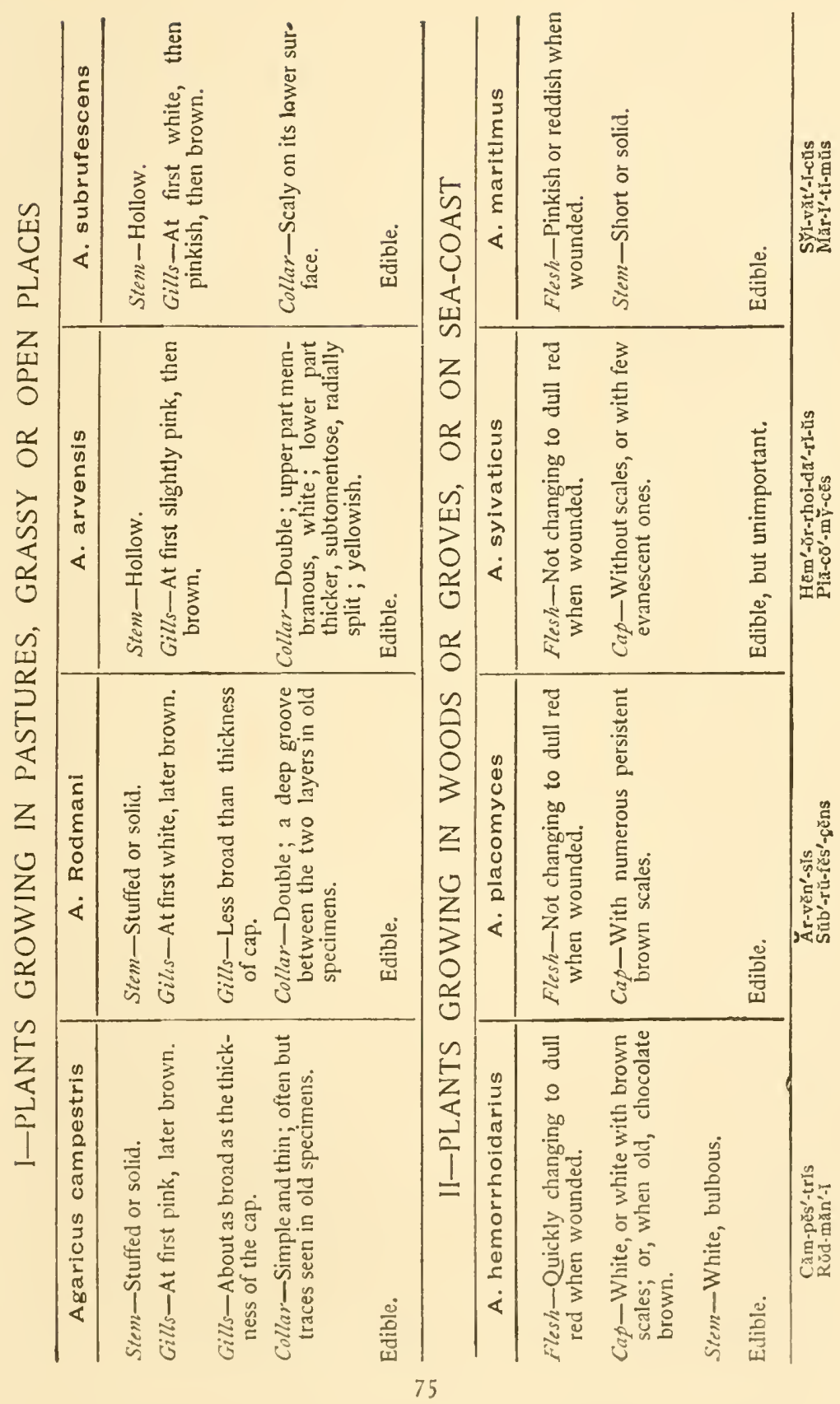


Fungi with Gills

\section{Common Mushroom (Edible)}

Agaricus campestris (See Plates Facing Pages 74 and 75)

Cap or Pileus-Silky, or with fine fibres. The young plants"buttons" - are hemispherical or almost globose. The mature plants are convex or nearly flat. White, or tinged with dingy browns. Skin separable. Margin extending beyond the gills.

Gills or Lamclle-Delicate pink, then dark brown, covered by a veil in young plants. Crowded, rounded at the inner extremity. Not attached to stem

Stem or Stipe-White, smooth; stuffed; that is, softer within than without. Shorter than the diameter of the cap.

Ring or Anmulus-Delicate, often disappearing with age.

Flesh-White. Much esteemed.

Spores-Brownish, elliptical.

Time-Late summer and autumn.

Habitat-In pastures, lawns, and open places.

Agaricus campestris is the mushroom ordinarily seen in the markets, either fresh from the growers or preserved in cans.

\section{Rodman's Mushroom (Edible)}

Agaricus Rodmani

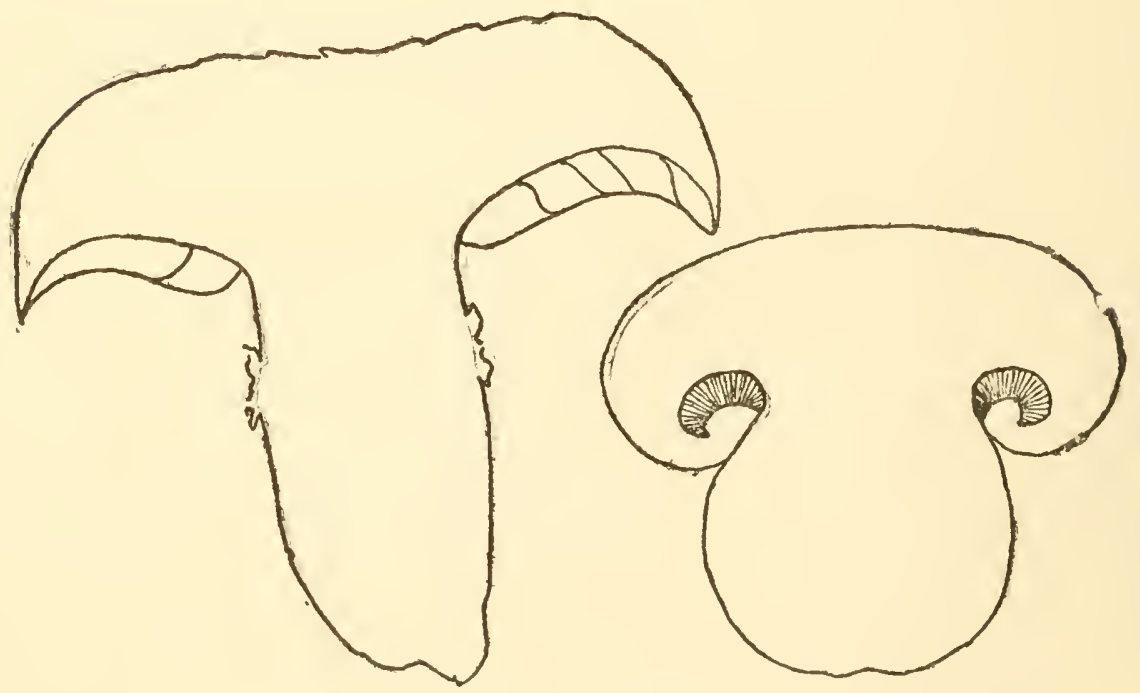

Sections of A. Rodmani

Căm-pěs'-trǏs Rŏd-năn'·ī 


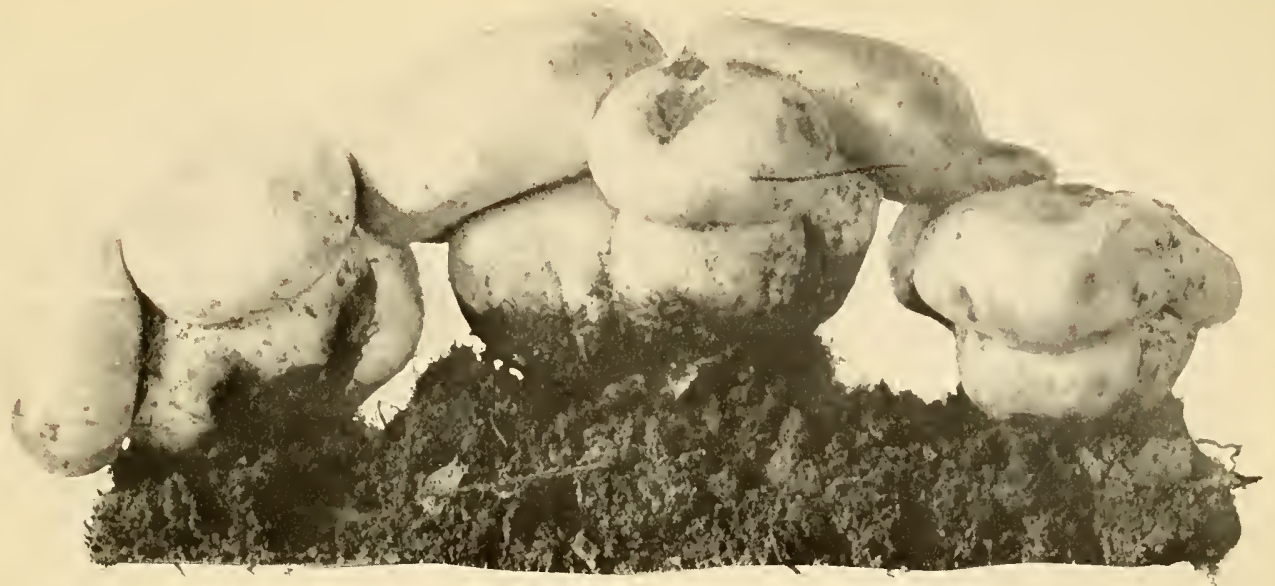

RODMAN'S MUSHROOM, YOUNG (EDIBLE)

(Agaricus Rodmani, Pcck. Reduced)

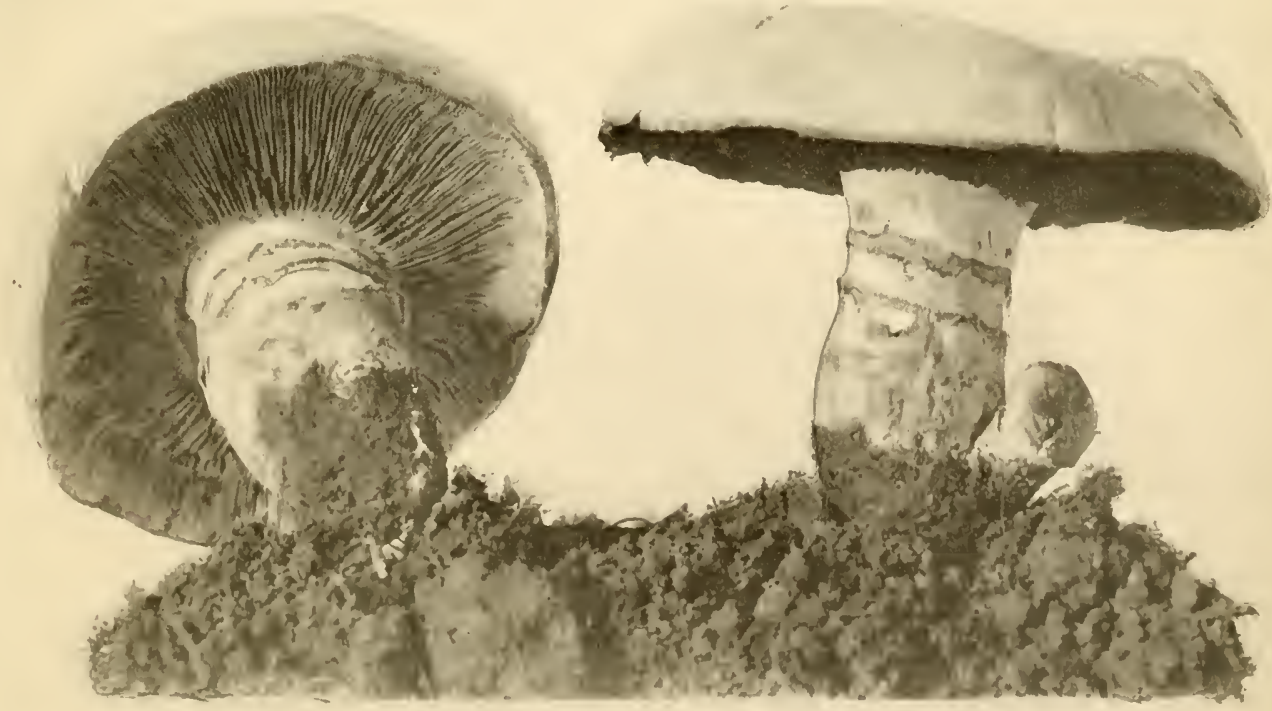

RODMAN'S MUSHROOM, MATURE (EDIBLE)

(Agaricus Rodmani, Peck)

Nat. size: Cap diam., 3// inches; stem length, 2 inches 




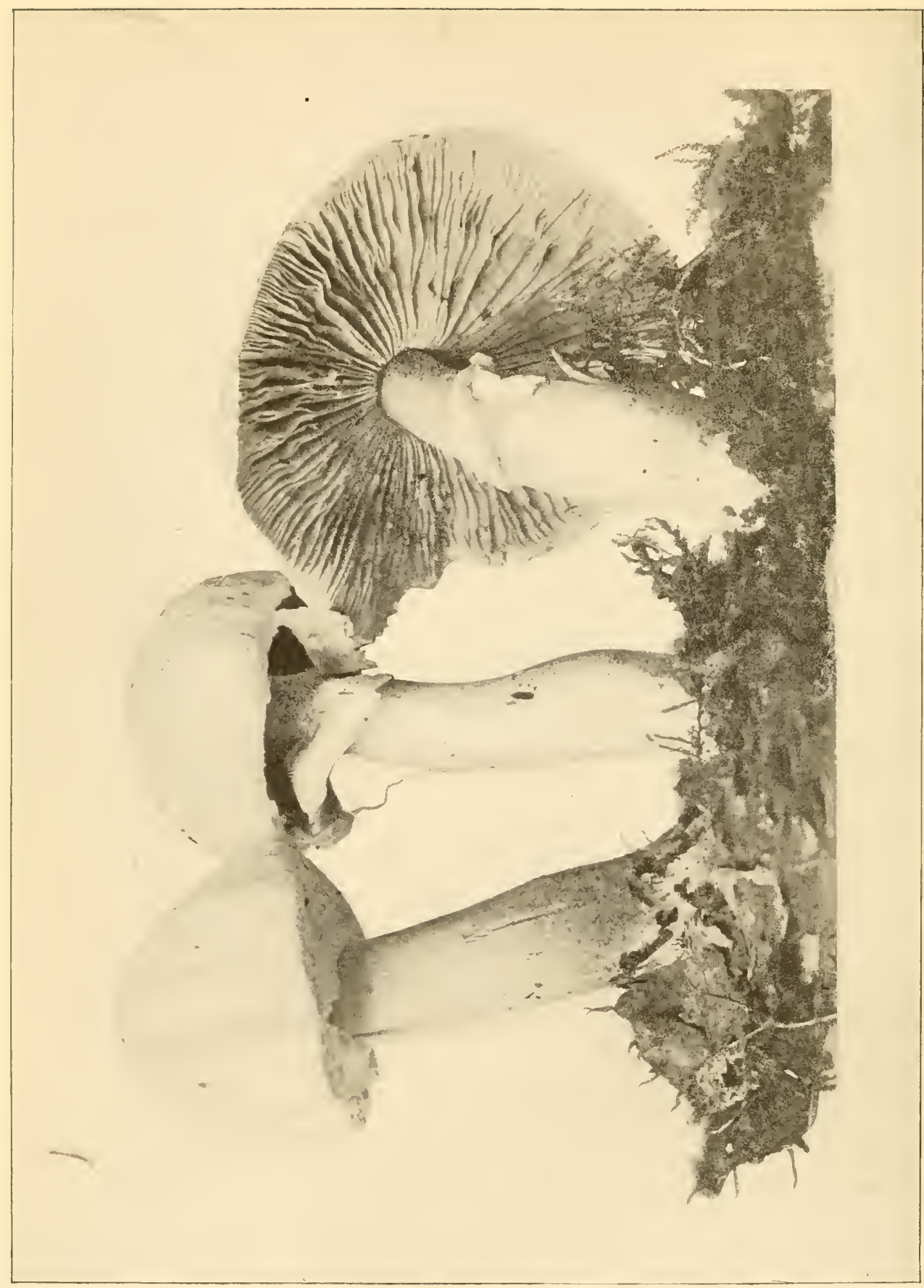

है 
Caf or Pileus-Creamy, with brownish spots. Firm, surface dry. Mature specimens frequently have the surface or the cap broken into large, brownish scales. $33 / 4$ inches broad.

Gills or Lamelle-Whitish, then pink, becoming dark brown. Narrow, close, unequal.

Stem or Stipe -Fleshy, solid, short, thick. 2 inches long.

Ring or Annulus-Double.

Spores-Brown.

Flesh-Firm, whit 2, assuming a pinkish or salmon tint. When cut, agreeable nutty flavour.

Time-May to July.

Habitat-Grassy grounds, crevices of unused pavements. The specimen photographed was found growing in a cluster between broken stone in the gutter of a village street in New Jersey.

\section{Agaricus ab-} ruptus (Edible)

CaporPileus-Creamy white, dry, and silky. Irregular in shape when young. Yellow when bruised.

Gills or LamellaSlightly pinkish when the veil first breaks; deeper pink in mature specimens, becoming brownish. Soft, free from the stem, crowded, unequal.

Stem or Stipe-Creamy white, deeper cream, or brownish near the base. Hollow, stiff, brittle, sometimes

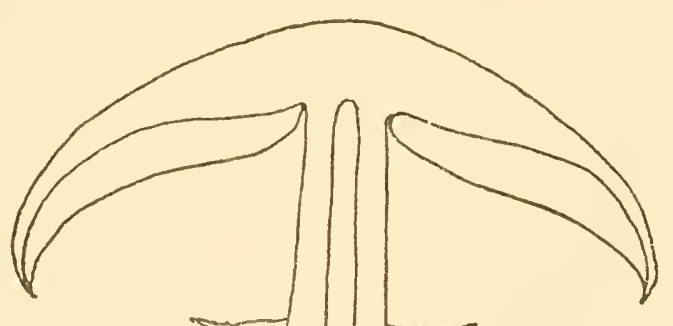


splitting lengthwise. Abruptly bulbous at the base, tapering toward cap. 3 inches long.

Spores-Brown.

Veil and Anmulus-Frail, part adhering to the margin of the cap, part forming a ring on the stem.

Flesh-White, solid. Decided taste of pistachio-nut.

Time-September.

Habitat-The specimen photographed grew by the trail along Lake Placid.

\section{GENUS HYPHOLOMA}

This genus has brown spores, and no volva at the base of the stem. The veil remains as a fringe attached to the margin of the pileus, but is not always apparent in old specimens; no portion remains as a ring on the stem. The gills are attached or grown fast to the stem at their inner extremity. In this respect, and also in having the stem destitute of a collar, the genus differs from the genus Agaricus.

\section{Perplexing Hypholoma (Harmless)}

\section{Hypholoma perplexum}

Cap or Pileus - Convex or nearly plane, smooth, sometimes slightly umbonate. Reddish or brownish red, fading to yellow on the margins.

Stem or Stipe-Firm and hollow, slightly covered with fine threads. Whitish or yellowish to rusty red or red brown. $2-3$ inches long.

Veil or Ring-Veil remains attached to the margin. No ring on the stem.

Gills or Lamella-Thin, crowded, slightly rounded at the stem end. At first pale yellow, then tinged with green or purplish brown.

Spores-Purplish brown, elliptical.

Flesh-Mild, not clearly bitter, white.

Time-Autumn to freezing weather.

Habitat-Grows in clusters, sometimes singly, on stumps, in the woods or in the open.

Six allied species of Hypholoma may be readily distinguished by reference to the table.

$$
\text { Hȳ'-phǒ-lō'-mă }
$$$$
\text { Pĕr-plěx'-ŭm }
$$ 


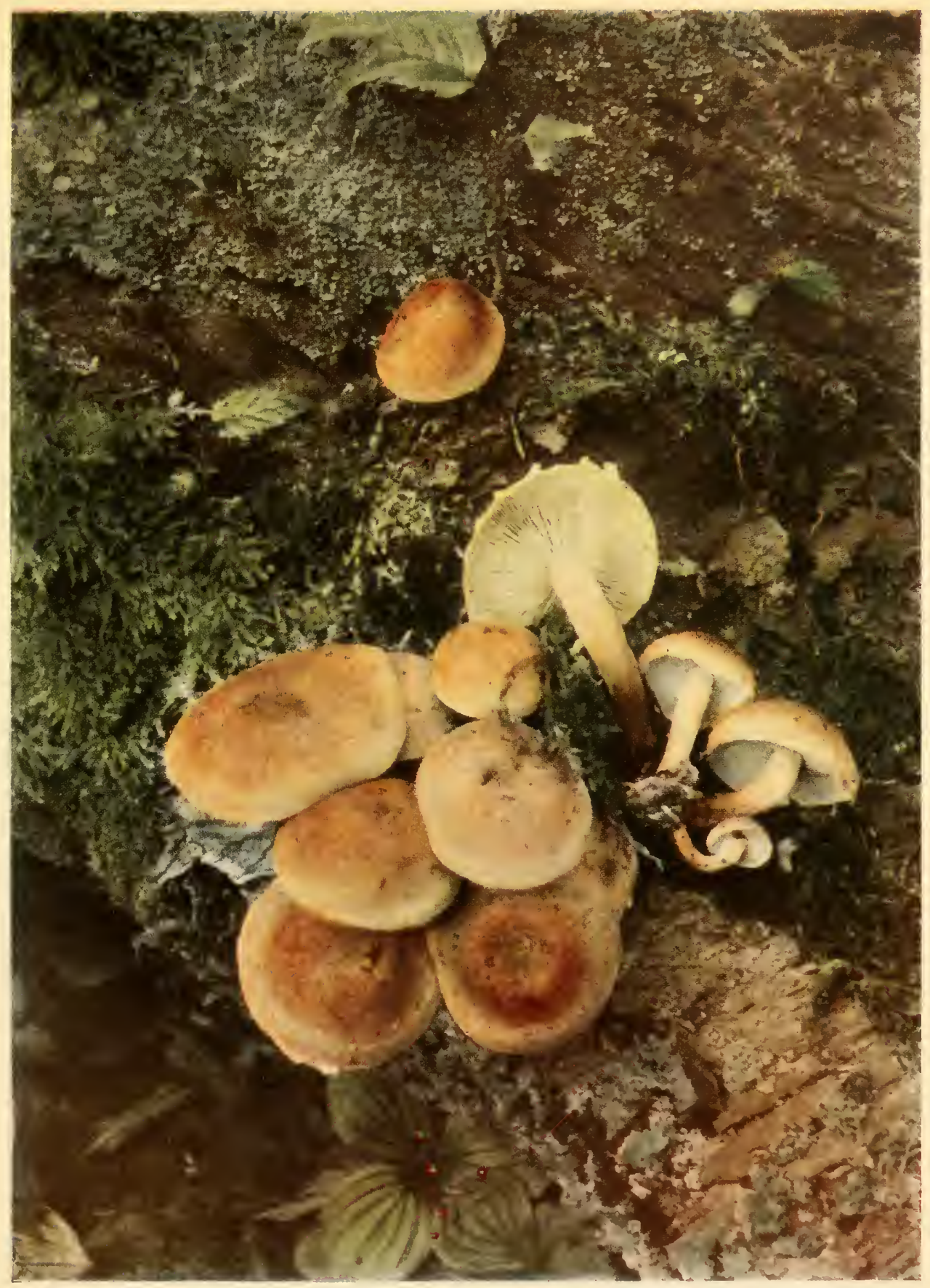

Perplexing Hypholoma (harmless).

(Hypholoma perplexum, Pk.). 



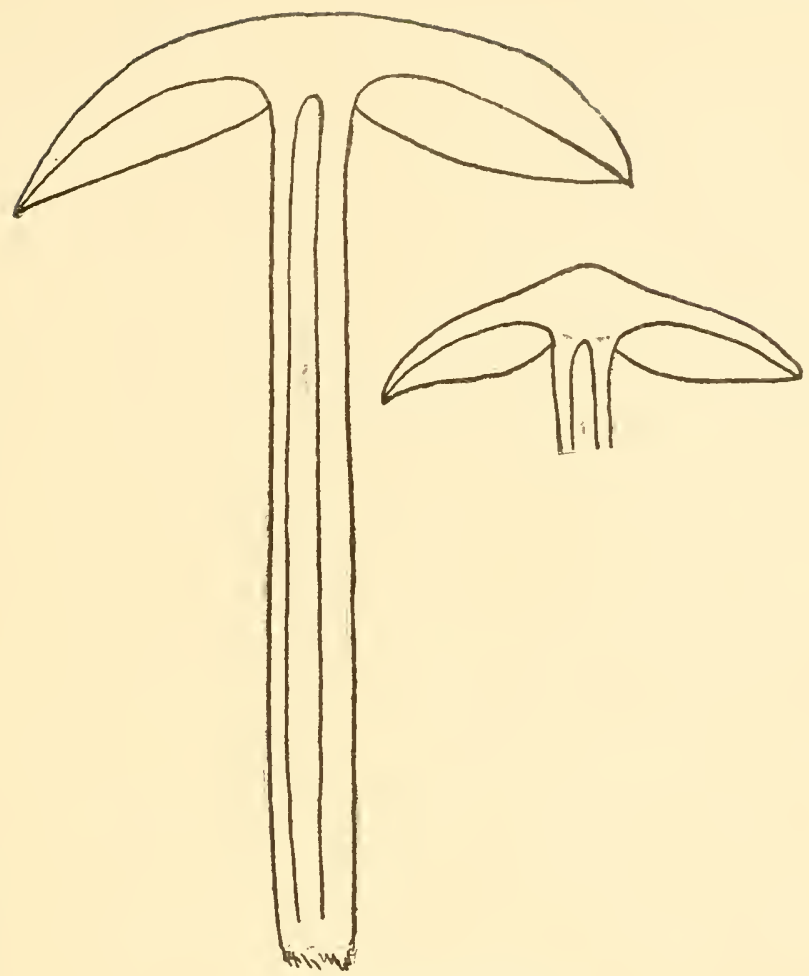

Section of H. perplexum

\section{I-TASTE MILD OR NOT CLEARLY BITTER}

\begin{tabular}{|c|c|c|}
\hline $\begin{array}{l}\text { H. epixanthus } \\
\text { Gray-gilled Mush- } \\
\text { room }\end{array}$ & H. capnoides & $\begin{array}{l}\text { H. perplexum } \\
\text { Perplexing Mush- } \\
\text { room }\end{array}$ \\
\hline $\begin{array}{l}\text { Gills-Yellow, be- } \\
\text { coming grey; } \\
\text { neither green nor } \\
\text { purplish. }\end{array}$ & $\begin{array}{l}\text { Gills_-Grey to purple- } \\
\text { brown. }\end{array}$ & $\begin{array}{l}\text { Gills-Yellow, green, } \\
\text { or purple brown. }\end{array}$ \\
\hline $\begin{array}{l}\text { Cap-Y ellow or } \\
\text { slightly tawny on } \\
\text { disk only. }\end{array}$ & $\begin{array}{l}\text { Cap_- Y e llow or } \\
\text { slightly tawny on } \\
\text { the disk only. }\end{array}$ & $\begin{array}{l}\text { Cap-Brick red, yel- } \\
\text { low on the margin. }\end{array}$ \\
\hline Taste-Mild. & Taste-Mild. & $\begin{array}{l}\text { Taste-Mild or not } \\
\text { clearly bitter. } \\
\text { Regarded as edible. }\end{array}$ \\
\hline
\end{tabular}

$\breve{E}^{\prime}$-pI-xăn'-thŭs

Căp-noi'-dēs 
Fungi with Gills

II-TASTE BITTER

\begin{tabular}{|c|c|c|}
\hline H. elæoodes & $\begin{array}{c}\text { H. fasciculare } \\
\text { Tufted Yellow Mush- } \\
\text { room }\end{array}$ & $\begin{array}{c}\text { H. sublateritium } \\
\text { Brick-red Mush- } \\
\text { room }\end{array}$ \\
\hline Gills-Green to olive. & $\begin{array}{l}\text { Gills-Yellow to } \\
\text { green. }\end{array}$ & $\begin{array}{l}\text { Gills-Whitish to } \\
\text { sooty olive. }\end{array}$ \\
\hline Cap-Brick red. & $\begin{array}{l}\text { Cap-Yellow tinged } \\
\text { with tawny. }\end{array}$ & Cap-Brick red. \\
\hline Stem-Hollow, rusty. & $\begin{array}{l}\text { Stem-Hollow, yel- } \\
\text { low. }\end{array}$ & $\begin{array}{l}\text { Stem-Solid or } \\
\text { stuffed. }\end{array}$ \\
\hline Flesh-Yellow. & Flesh-Yellow. & Flesh-Whitish. \\
\hline Taste-Bitter. & $\begin{array}{l}\text { Taste-Bitter. } \\
\text { Reputed poisonous. }\end{array}$ & $\begin{array}{l}\text { Taste-Bitter. } \\
\text { Reputed poisonous and } \\
\text { edible. }\end{array}$ \\
\hline
\end{tabular}

\section{Uncertain Hypholoma (Edible)}

\section{Hypholoma incertum}

Cap or Pileus-Thin, fragile, whitish. Margin often wavy and adorned with the fragments of the woolly white veil. Opaque when dry, transparent when moist. Ovate at first, then broadly spreading. $\mathrm{I}-2 \mathrm{I} / 2$ inches wide.

Gills or Lamelle-

Thin, narrow, close; fastened to the stem at their inner extremity. White at first, then purplish brown.

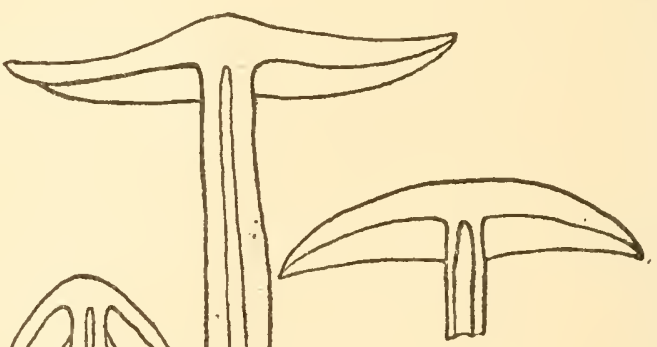

Él'-æ-ö'-dēs

Făsc'-Ic-ŭ-1ä'-rĕ

Section of $\mathrm{H}$, incertum

Sŭb-lā-těr-1'-shI-ŭn In-çěr'-tŭm So 


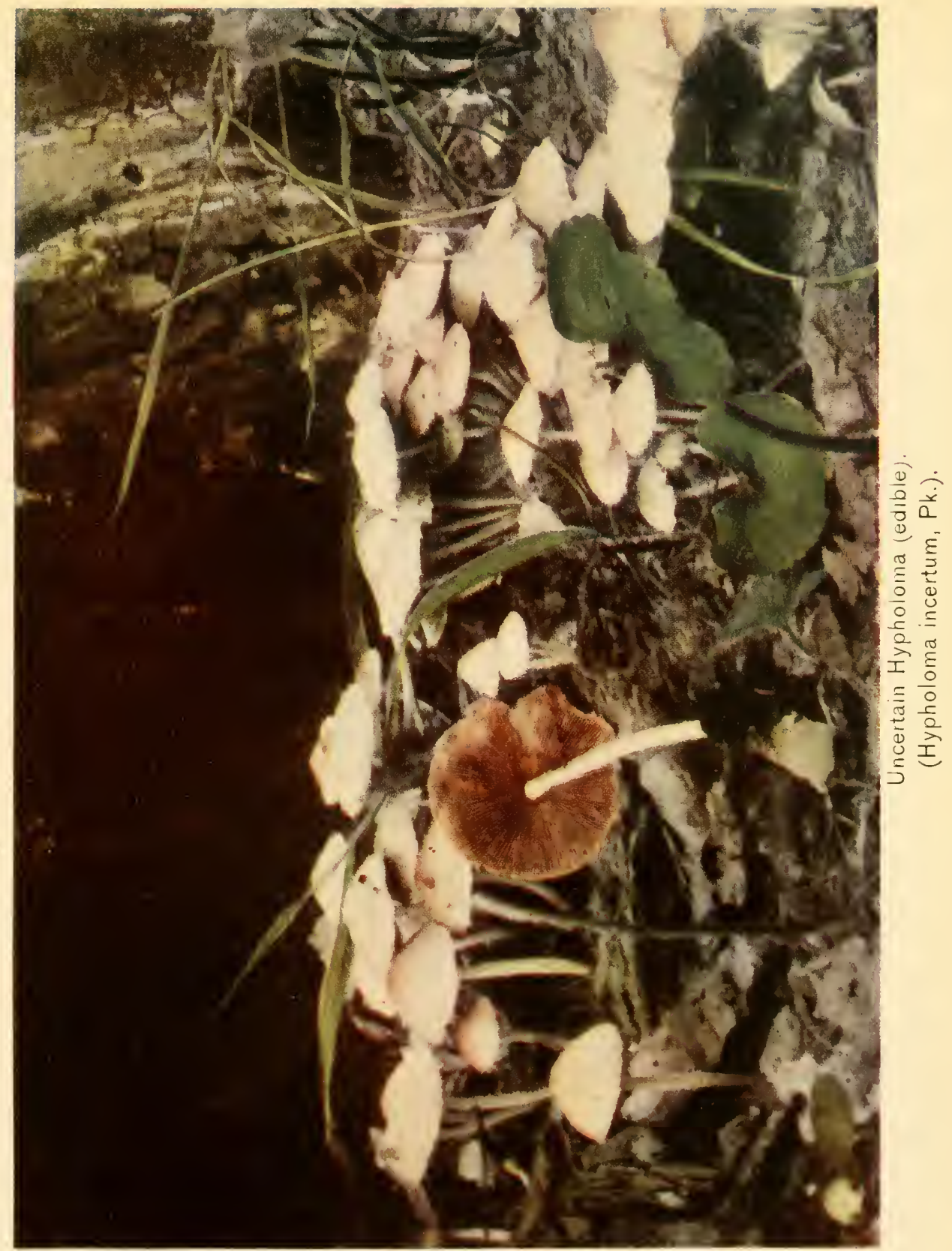






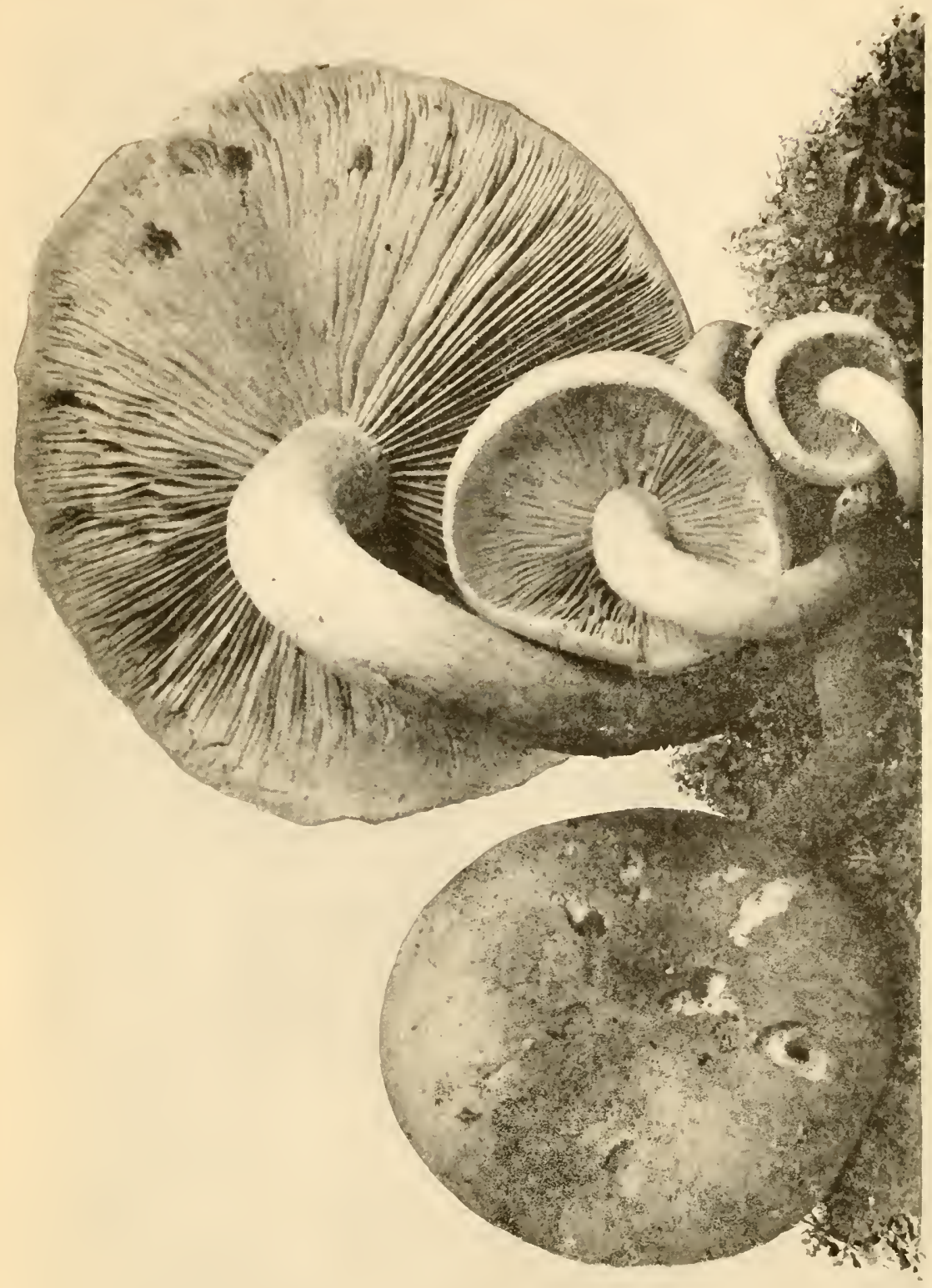

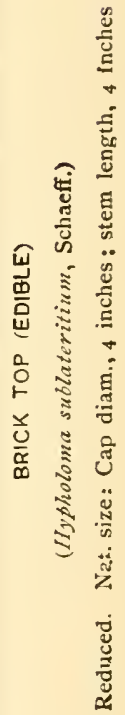


Stem or Stipe-Hollow, white, and slender. 1-3 inches long. Spores-Purplish brown, elliptical.

Flesh-Tender.

Time-Throughout a moist season.

Habitat-In clusters, in lawns, gardens, thin woods, and pastures.

\section{Brick Top (Edible) \\ Hypholoma sublateritium}

Cap or Pileus-Brick red, with pale yellowish border. Surface covered with fine silky fibres. Fleshy, firm, moist. 21/2-4 inches broad.

Stem or Stipe-Creamy when young, lower part slightly tinged with red.

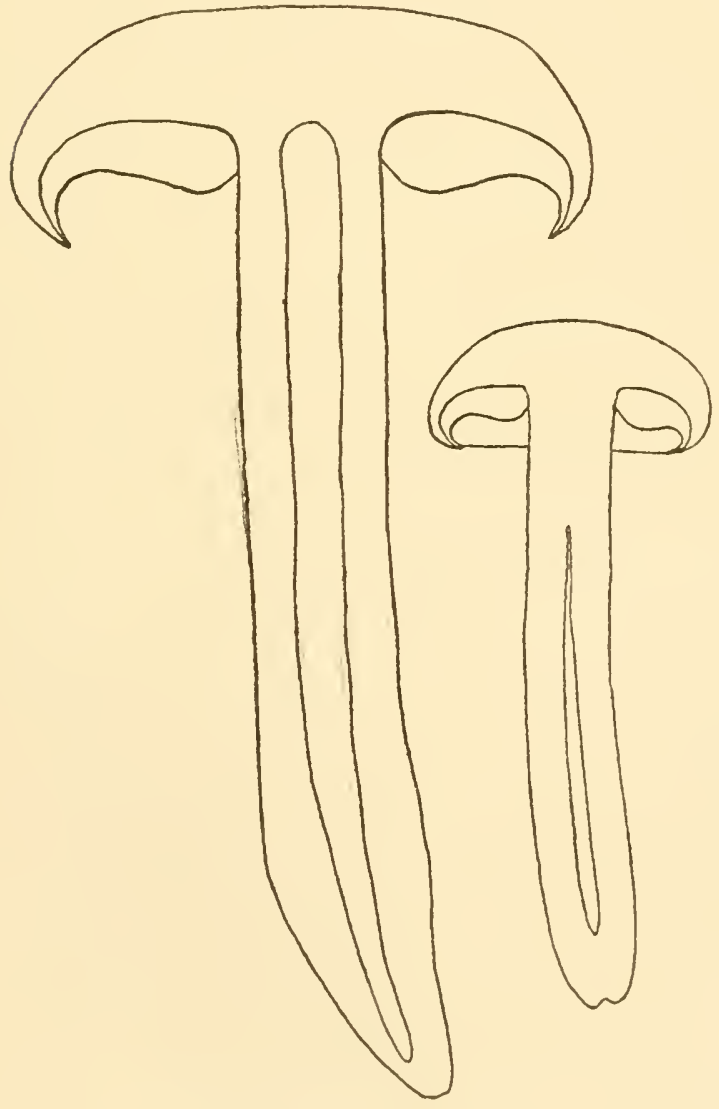

Section of 11. sublateritium

Hollow or stuffed. Silky fibres on the surface. $21 / 2-$ 4 inches long. Gills or Lamella$\mathrm{Cr}$ e a m y when young, olive when old. Attached to stem at inner extremity. Rather n a r row, crowded, unequal.

Ring or AnnulusNone. Remnants of veil often seen on edge of cap.

Spores-Brown.

Flesh-Creamy, firm, bitter.

Time-September.

Ilabitat - The specimen photographed grew in clusters on a mossy stump in the open. 


\section{GENUS STROPHARIA}

There are about seven species of this genus in America. The spores are brown, there is no volva, the stem has a collar, and the lamellæ are united with the stem. They have no special economic importance.

\section{GENUS PSATHYRA}

Two American species are reported for this genus. The spores are dark brown, there is no volva, the veil is inconspicuous or wanting, and the lamellæ attached to the stem or notched at the inner extremity. The margin of the cap in the young plant and mature plant is always straight.

\section{GENUS PSILOCYBE}

Eleven American species are reported for this genus. The spores are dark brown. There is no volva, the veil is inconspicuous or wanting, and the lamellæ are attached to the stem or notched at the inner extremity. In the young plant the cap curves in at the margin.

\section{GENUS PILOSACE}

This genus has but one American species recorded. The spores are dark brown. There is no volva, and the veil is inconspicuous or wanting. The lamellæ are free from the stem.

\section{GENUS DECONICA}

But one American species is reported. This has dark brown spores, and the lamellæ growing down on the stem. The veil is inconspicuous or wanting, and there is no volva.

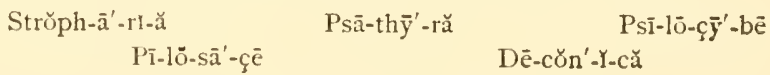

$$
\begin{aligned}
& 82
\end{aligned}
$$




\section{GENUS CHITONIA}

One American species is reported in this genus, Clarkeinde plana, from Nebraska. The spores are brown, and the stem has a volva at the base, but no ring.

\section{GENUS PHOLIOTA}

The members of this genus have rusty spores, and an annulus on the stem. There are about twenty known species, and some of these are edible.

\section{Fat Pholiota (Edible)}

\section{Pholiota adiposa (See Plate Facing Page 61)}

Cap or Pileus-Showy, deep yellow, with little scales of reddish brown. Fleshy, firm. At first hemispherical, then convex. Sticky when moist, shiny when dry. $2-4$ inches broad.

Stem or Stipe-Stem yellow, generally rusty at the base. Equal in diameter, or slightly thickened at the base. Stuffed or solid. Tough.

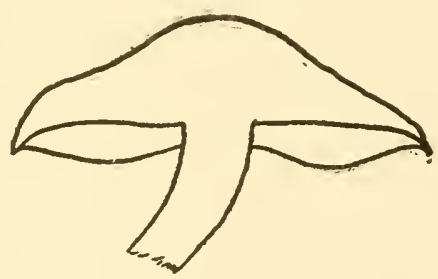

Section of P. adiposa

Gills or Lamelle-Yellowish, becoming rusty; close, and attached to the stem.

Ring or Annulus-Slightly radiating, woolly.

Spores-Rusty brown.

Time-September to November.

Habitat-ln tufts, on stumps or dead trunks of trees.

Pholiota limonella, lemon-yellow pholiota, has a smaller, thinner, and more expanded cap, of a lighter yellow, with white gills.

$$
\text { ChY-tō'-nY-X }
$$

Phō-1Y-ō'-tæx

Ăd-I-pō'-š̆ 


\section{Early Pholiota (Edible)}

\section{Pholiota pracox}

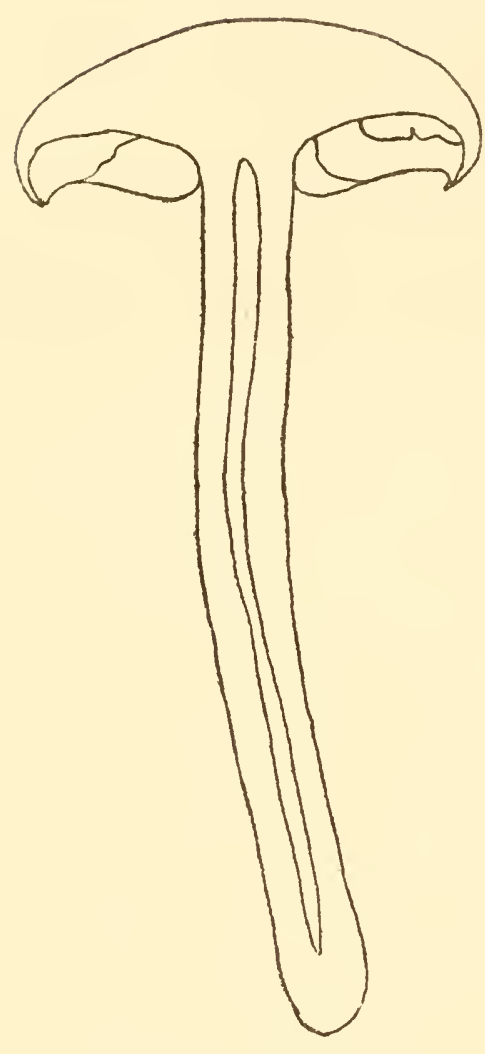

Section of P. precox
Cap or Pileus-Creamy white, smooth, not shining. Very thin skin. $1-2$ inches long.

Stem or Stipe-Creamy white, rather scaly. Skin peels readily. Stuffed or hollow. $1-5$ inches long.

Gills or Lamelle-Creamy white when young, brown when mature. Soft, close, unequal, notched at the inner extremity, and attached to the stem.

Veil and Ring-Stretched like a drumhead from stem to margin of cap. Variable in manner of parting. It sometimes separates from cap margin, and forms a distinct ring about the stem; agair, but little remains on the stem, and much on the rim of the cap.

Spores-Rusty brown.

Flesh-White, solid though soft, moist. Taste slightly bitter. Time-May to July.

Habitat-Grassy ground. The specimen pictured grew about the roots of a poplar tree in New Jersey.

\section{Pholiota aggericola}

(See Plate Facing Page 73)

Cap or Pileus-Brown, shining when moist. Margin in older specimens finely and closely impressed with parallel lines. Cap diameter of specimen photographed, 2 inches.

Gills or Lamella-Pale brownish when young, darker brown 


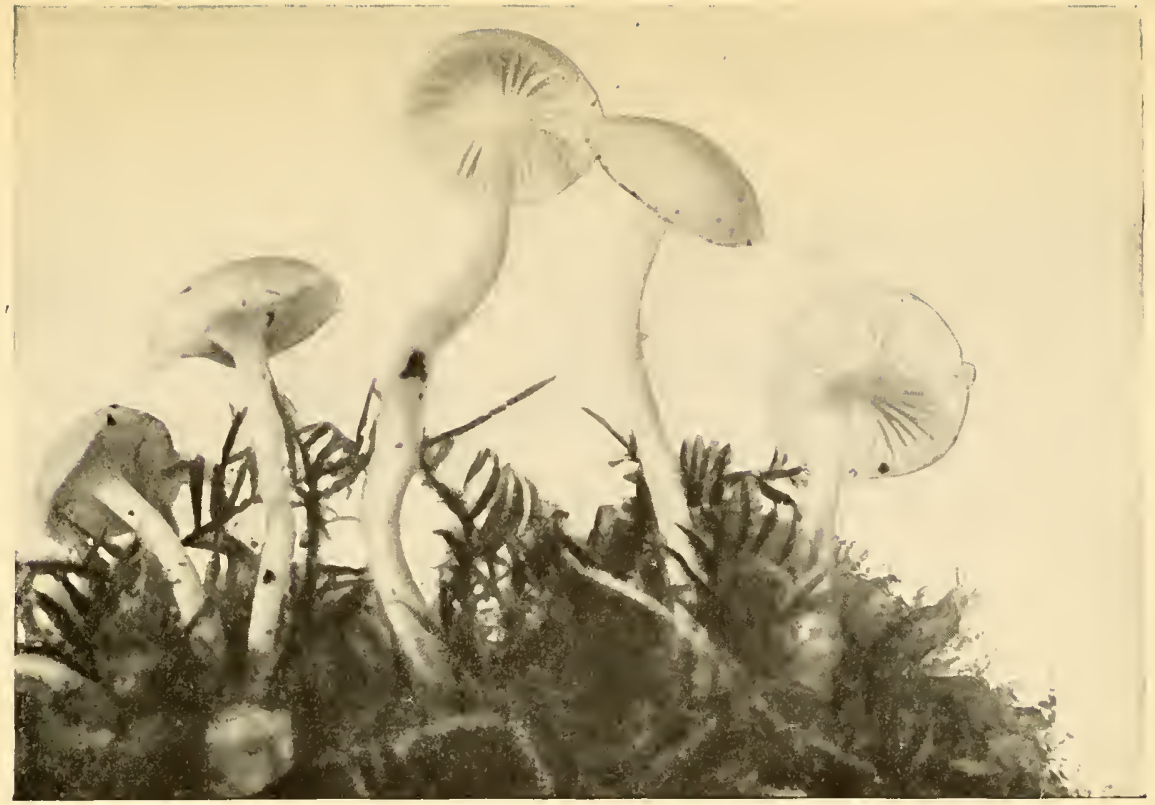

IVORY HYGROPHORUS (EDIBLE)

(Hygrophorns eburneus, Fries)

Reduced. Cap diam., I inch; stem length -34 inches Spe page 6 I

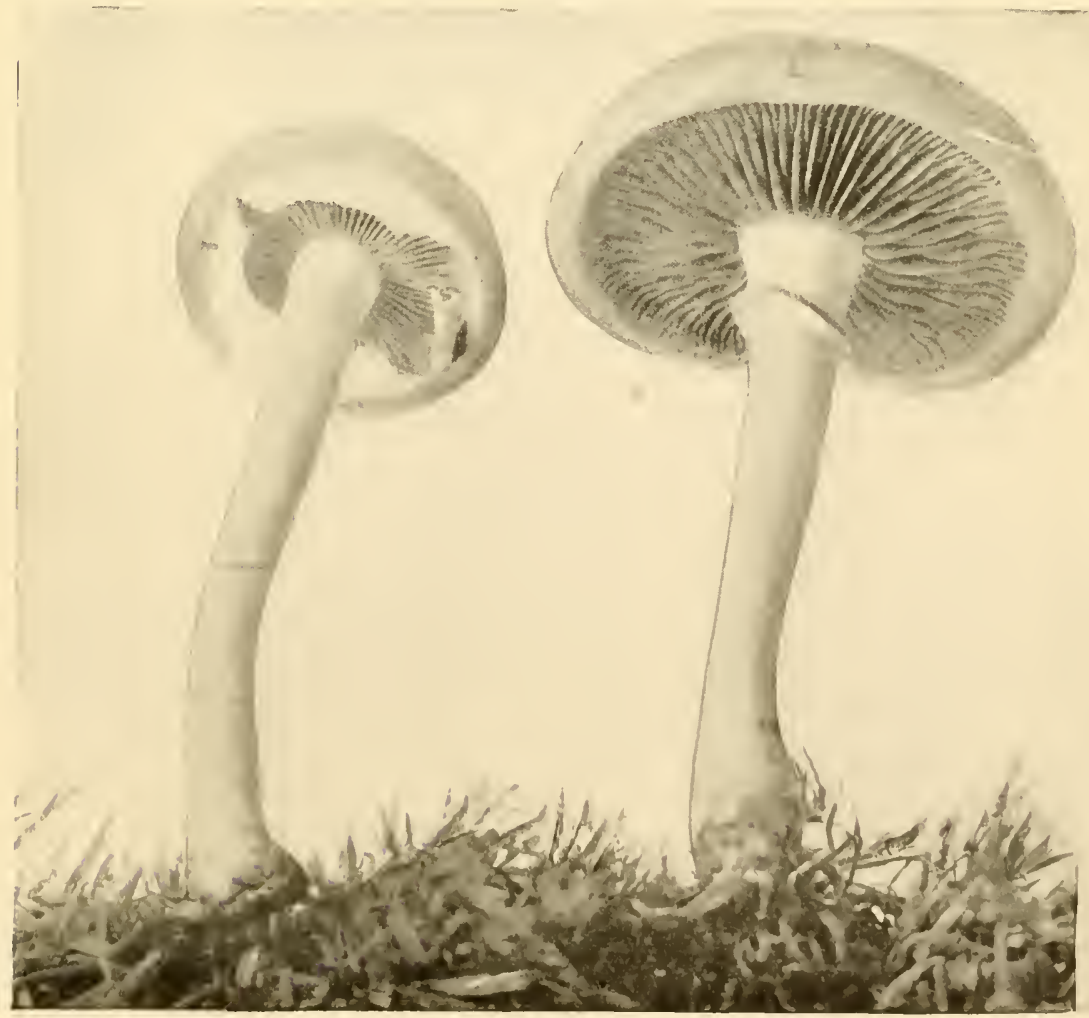

EARLY PHOLIOTA (EDIBLE)

(Sholiota pracox, Pers)

Reduced, Nat, size: Cap diam., $2^{1}$ inches; stem length, $3^{\text {If }}$ inches. 




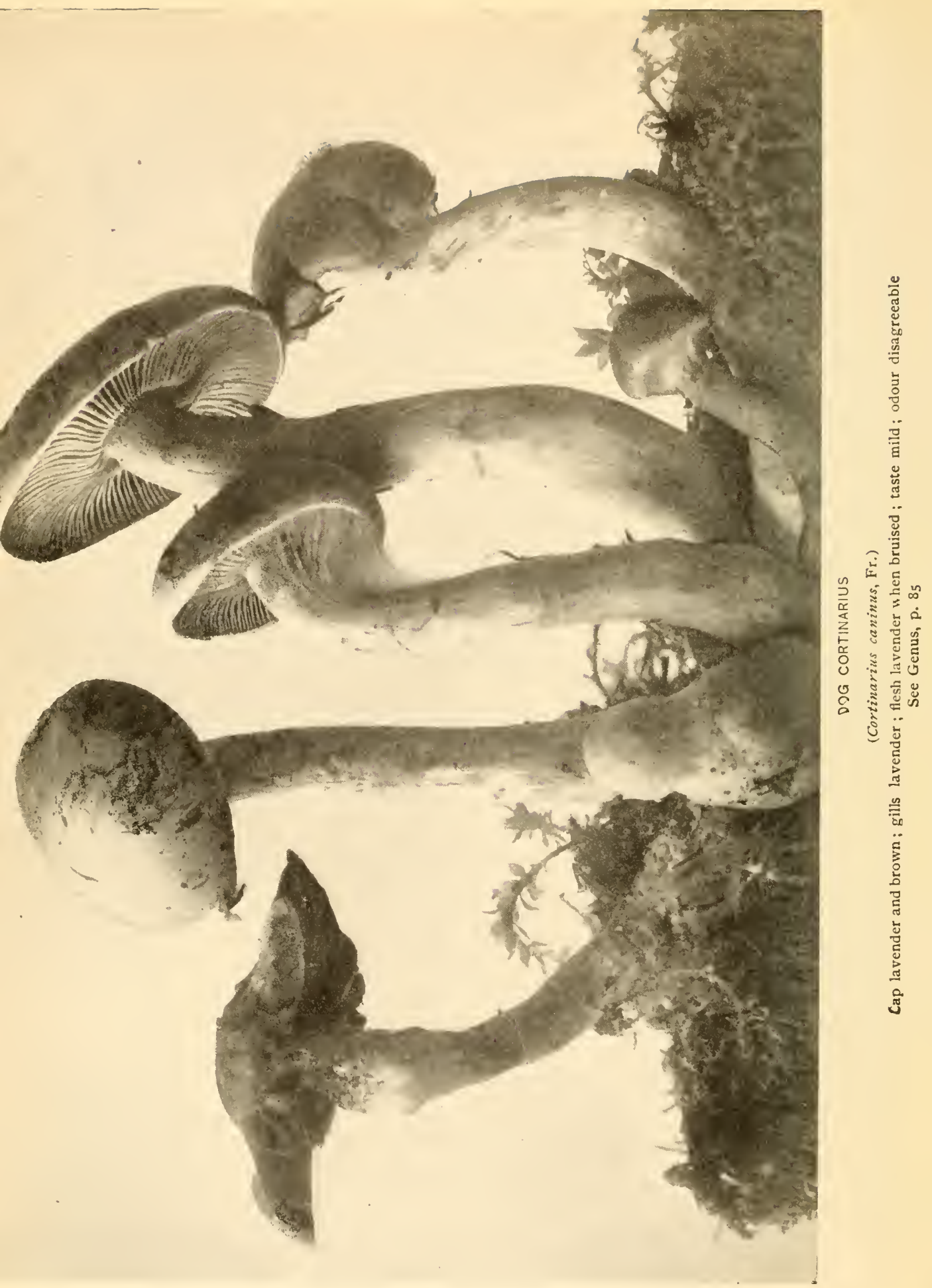


when mature. Attached to stem when young, free when older.

Veil-Pale brown, colour of stem.

Stem or Stipe-

Pale orown-

ish, darker at

base. Softer texture within than without. Stem length of $\mathrm{specimen}$ $\mathrm{p} h$ o t $\mathrm{O}$ graphed, 2 inches.

Spores - Rusty brown.

Flesh-P a le brownish; brittle. No t a s t e or ma $r k$ e d odour.

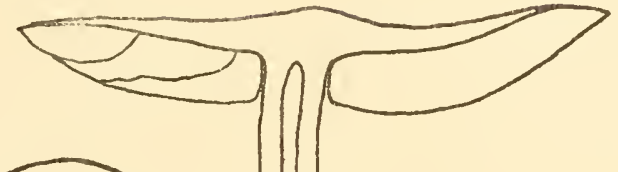

Time-October.

Habitat-Specimen photographed grew among grass and leaves in a New Jersey garden.

\section{GENUS CORTINARIUS}

This genus contains many species which are distinguished by the rusty yellow colour of their spores and by the webby character of the veil. It is of the utmost importance in identifying species of Cortinarius to know the colour of the gills of the young plant, as the gills of the old plants are almost uniform in colour, owing to their being dusted with the rusty yellow spores. In addition, one should carefully note the colour of the young plant compared with the old; the surface, whether sticky or dry, smooth or hairy; the taste; and the markings left on the stem by the retreating veil. All species have their gills attached to the stem, and some have them notched at the stem end. They may be looked for along the borders of woods and groves in hilly regions, during the latter part of the summer.

\section{Cơr-tŶ-nā'-rY'-ŭs}


Fungi with Gills

Cortinarius alboviolaceus (See Plate Facing Page 65)

Cap or Pileus-Lavender, paler in the centre. Surface with rusty spots. $21 / 2$ inches broad.

Gills or Lamellie-Crowded, unequal, attached to the stem.

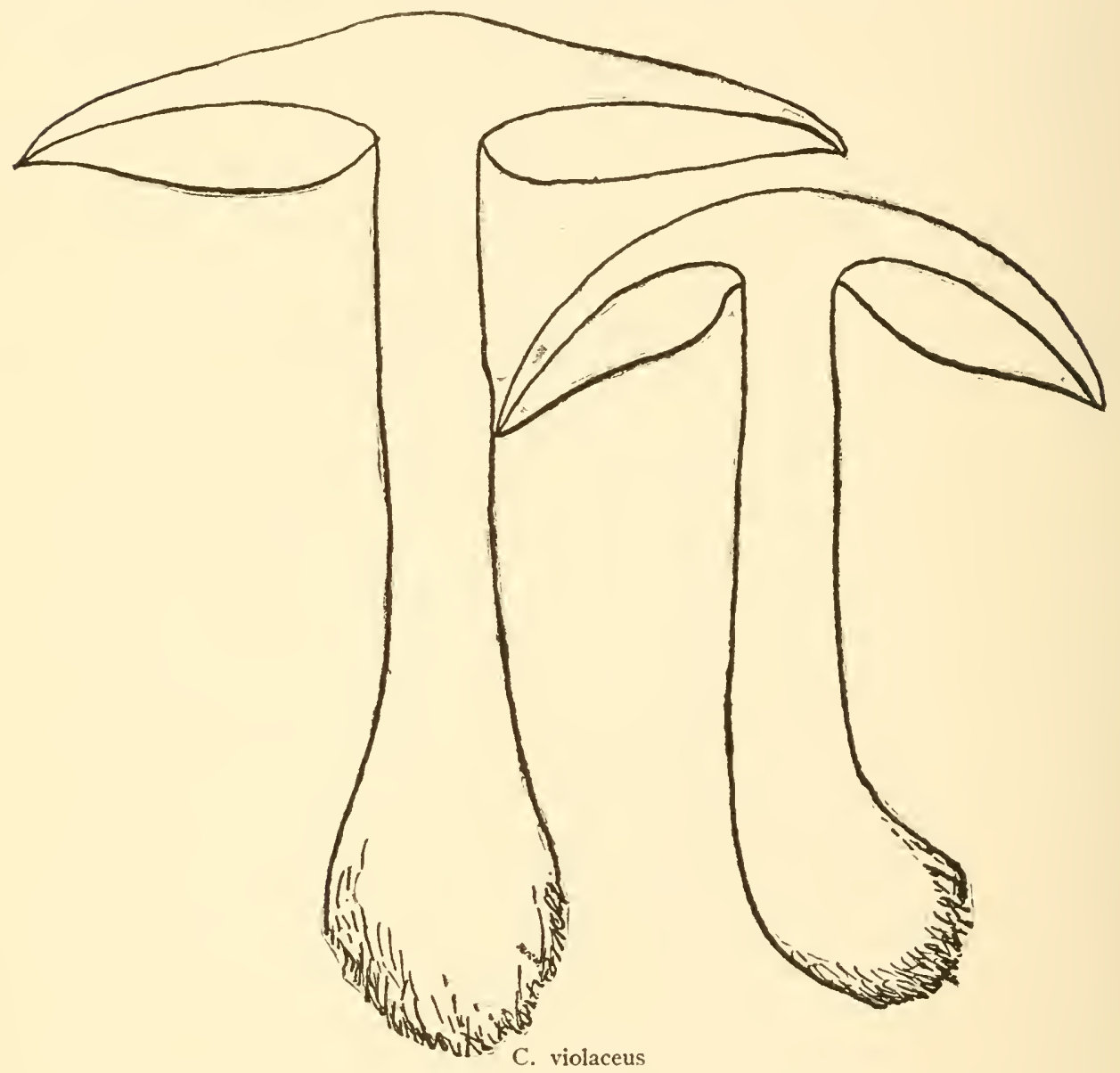

Stem or Stipe-Pale lavender, assuming a deeper shade when cut or bruised. Spongy in the centre, swollen toward the base. 3 inches long.

Veil-Filmy, stretching from stem to the margin of the cap in young plant.

Spores-Rusty brown.

Ăl-bō'-vī-ō-lā'-ç̌̌ -ŭs 


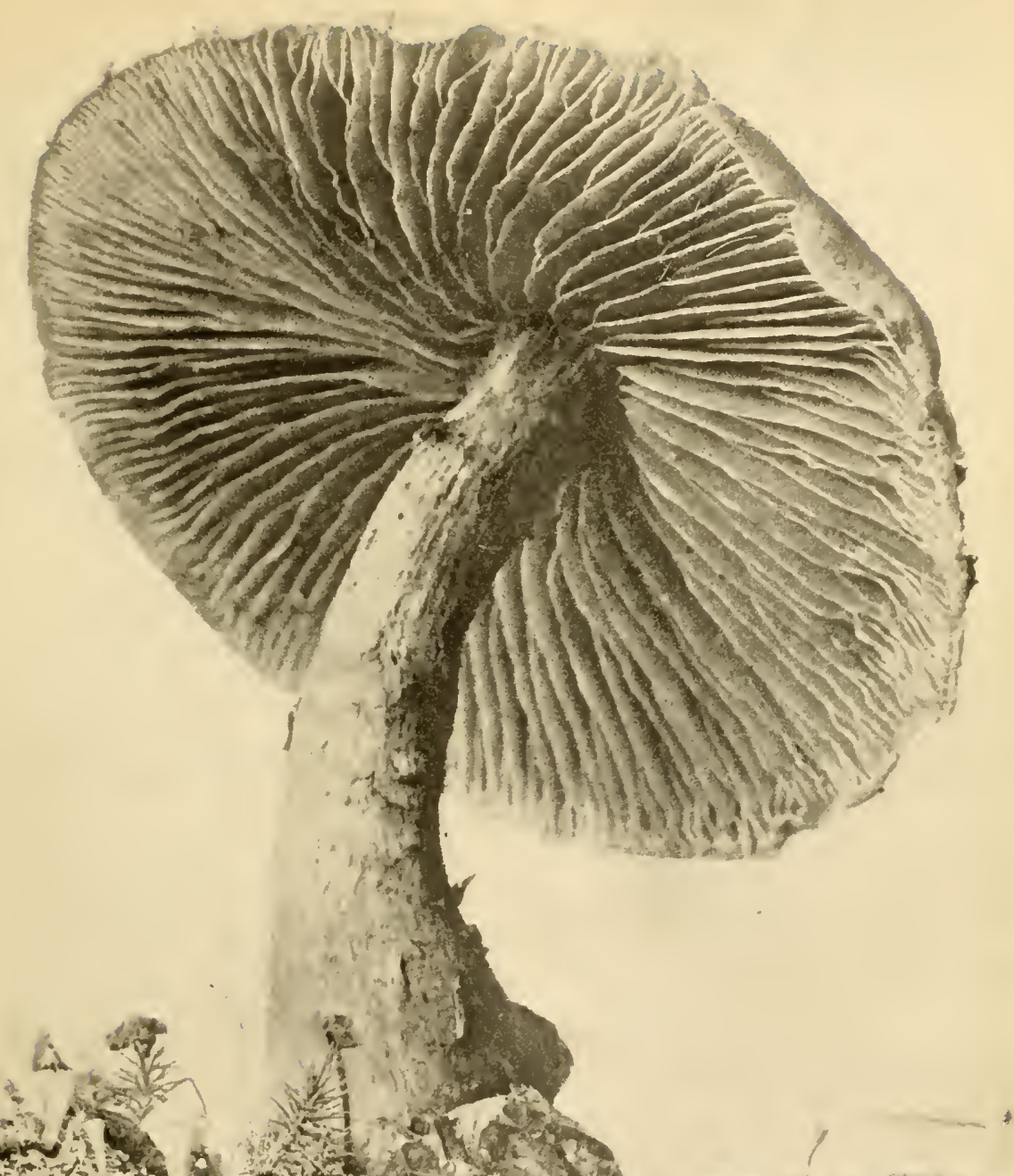

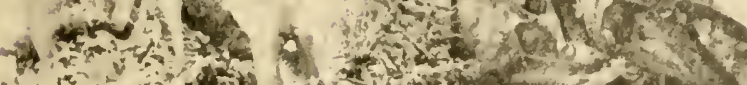

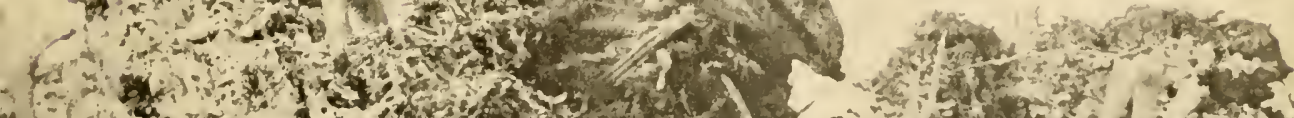

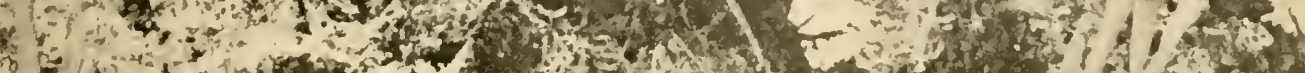

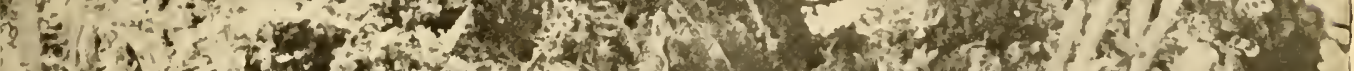
Jic

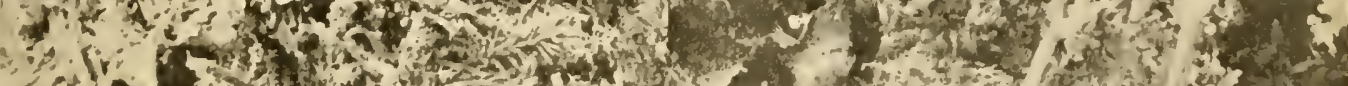
3 r.

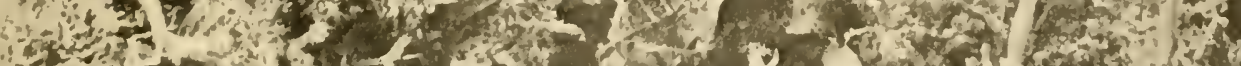

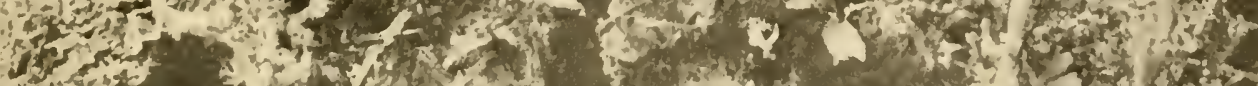

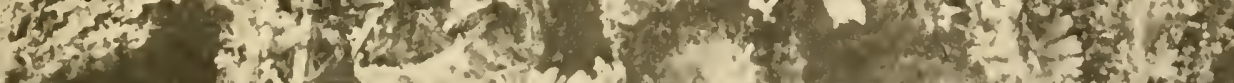
(2). (n) $\sqrt{2}+2$

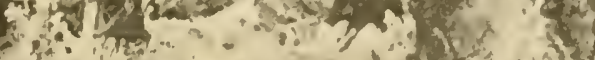

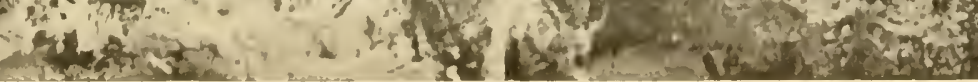





\section{Pink-spored Series}

Flesh-Tinged with violet.

Time-Autumn.

Habitat-Thick, damp woods.

C. violaceus differs from $c$. alboviolaceus in having the cap dark violet and usually covered with fibres.

\section{GENUS PLUTEUS}

The members of the genus Pluteus are fleshy fungi with pink spores, and gills free from the stem. They have no volva or wrapper about the young plant, and no ring or annulus on the stem. Eleven species are known from the United States, of which Pluteus cervinus, the fawn-coloured mushroom, is the commonest.

The generic name Pluteus means all that is joined together to make a cover for besiegers at their work, that they may be screened from the missiles of the enemy. The arrangement of the caps in the group pictured is suggestive of the meaning.

\section{Fawn-coloured Pluteus (Edible)}

Pluteus cervinus

Cap or Pileus-Light brown or fawn c o l o u re d, streaked with lines of darker brown. Surface dry and shining. Skin thin and papery. $3 \mathrm{~T} / 2$ in $\mathrm{Ches}$ broald.

Gills or LamellaAlmost white when young, flesh colour when mature. Broad, unequal in length, free from the stem. Stem or StipeCreamy white,

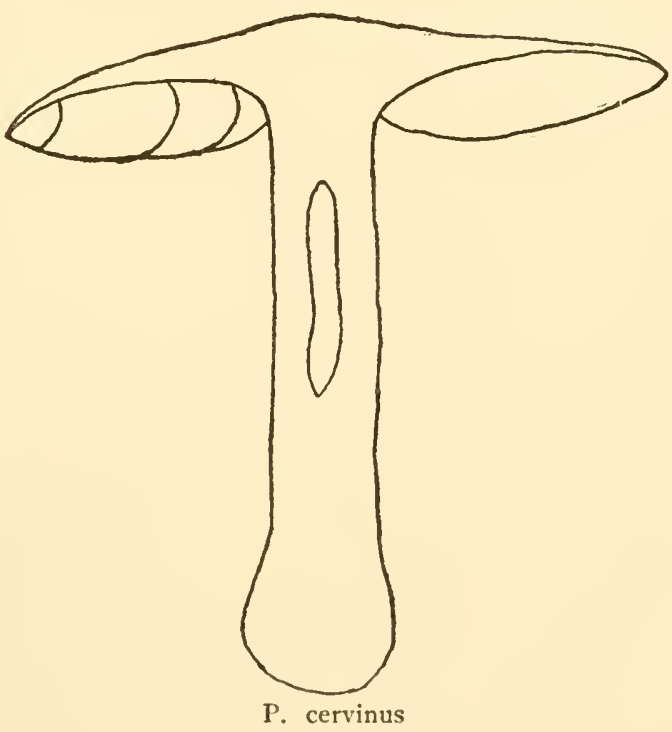

Plü'-të-n

Çĕr-vĩ'-nŭs 
streaked with pale brown. Brittle, pithy in the centre when mature. 3-6 inches long.

Spores-Pink, with suggestions of yellow; salmon colour.

Flesh-White, tasteless.

Time-Early in the season, May.

Habitat-Mixed woods, on and around old stumps. New Jersey.

\section{GENUS ENTOLOMA}

The members of this genus have pink spores, and the lamella attached to the stem, or with a notch near the junction of gill and stem. The stem is fleshy, and not tough and hard as in Leptonia and Nolanea, genera with pink spores and adnate or sinuate lamellx. There are some twelve species in this genus, none of which have any economic interest.

\section{GENUS ECCILIA}

The members of the genus Eccilia have neither volva nor annulus. The gills grow downward on the stem, the spores are pink, and the stems have a hard, tough rind, not fleshy as in Clitopilus. There are three species known in America.

\section{GENUS VOLVARIA}

The members of the genus Volvaria are fleshy fungi, soon becoming putrescent. The spores ale salmon colour. A volva is present, but no annulus. Distinguished from Amanitopsis by having salmon-coloured spores instead of white.

\section{GENUS CLITOPILUS}

The members of this group have neither volva nor annulus. The gills grow downward on the stem, the spores are pink, and the stem is fleshy, without a hard and tough rind as in Eccilia. There are fourteen American species, of which at least two species are edible.

$\breve{E}$ E-tǒ-lō'-mă

I. ĕp-tō'-nł-ă
Nō-lä'-nĕ-ă

Vǒl-vā'-ř̆-ă
Ĕc-çrı' -1-ă

Clì-tŏ-pī'-lŭs 


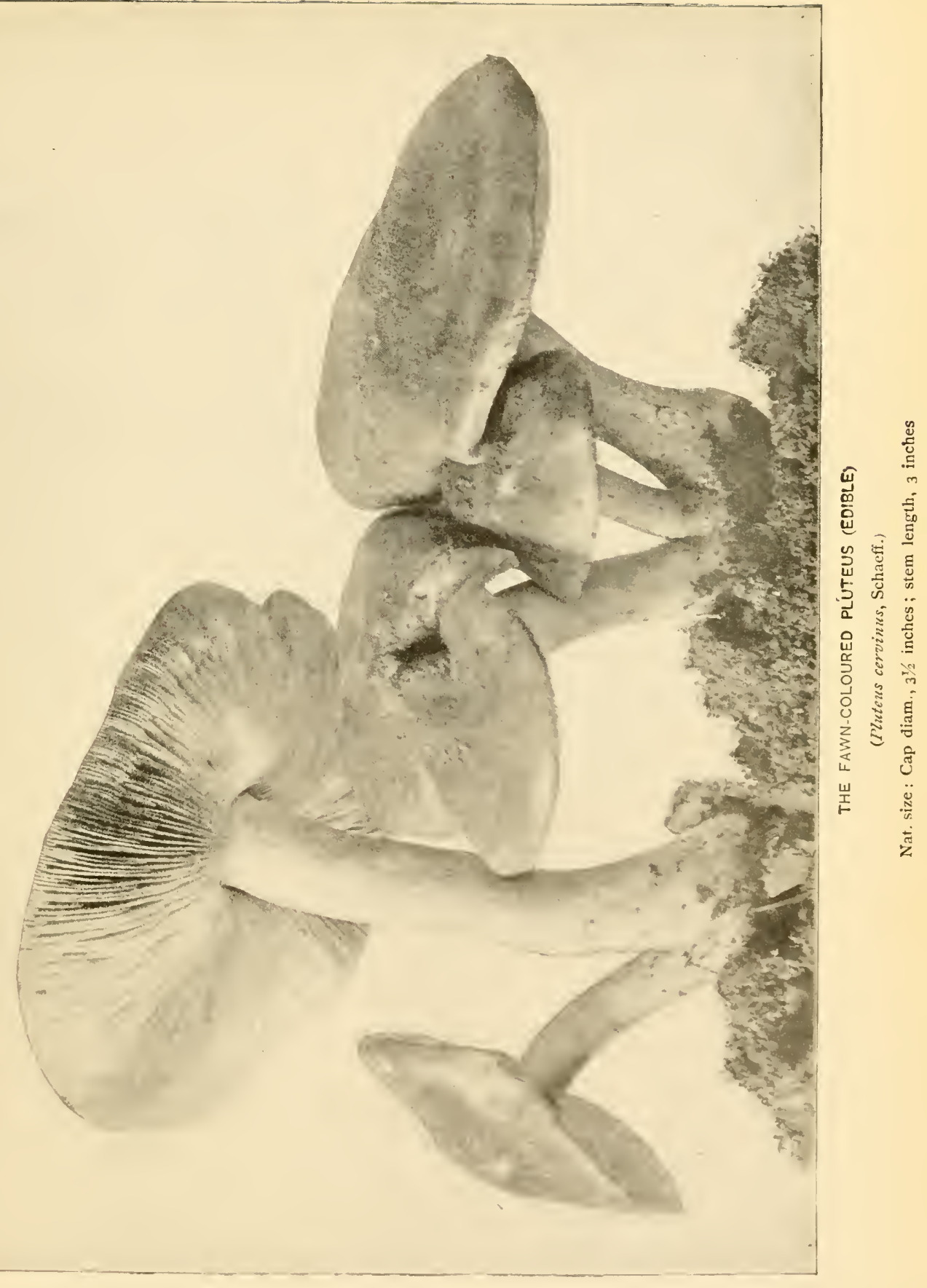






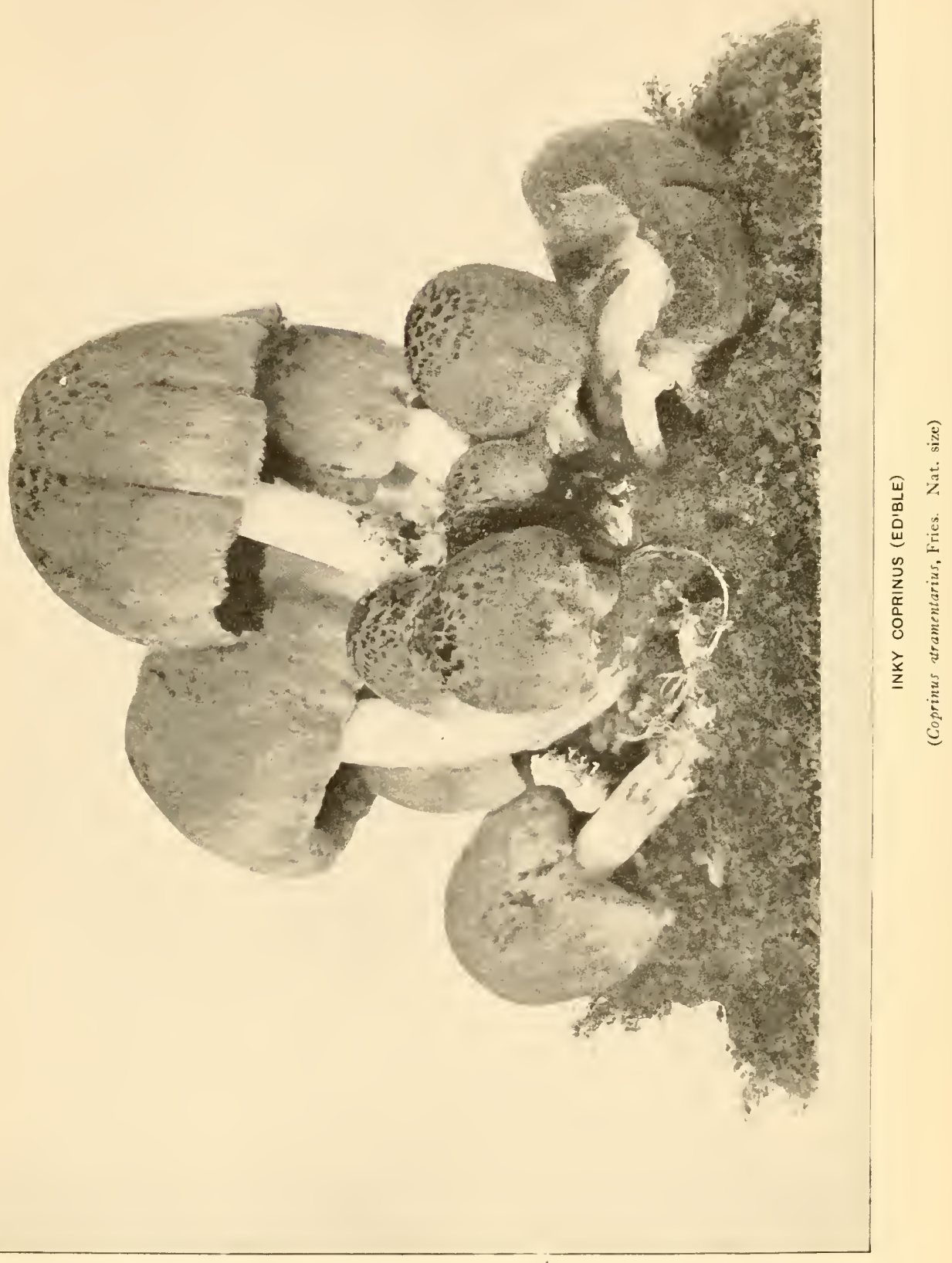




\section{GENUS COPRINUS}

\section{Ink Caps (Edible)}

The genus Coprinns may be readily recognised from the fact that the spore-bearing plates dissolve to an inky fluid soon after the spores mature.

An amateur mushroom hunter may feel perfectly safe in collecting ink caps for his table, as all the species large enough to tempt the collector are not only edible, but are generally conceded to be of the best.

Their general appearance is such that even the most untrained observer should not mistake them for species of other groups.

The oblong or nearly cylindrical cap, which does not expand until ready to dissolve in inky drops, is too striking a characteristic to permit of any one making a mistake in identifying it as a specimen safe to eat.

These plants literally grow up in a night and perish in a day, as their period of growth is spent underground, and it is not until all the parts of the fruiting portions of the plants are fully developed that they push themselves above ground. Then they push and crowd from the ground in such numbers, where but a few hours before no evidence of them was seen, that each one is compressed from its cylindricil form to that of a manysided prism, so that there would be no chance for the expansion of those within the group if it were not that those on the outer rim so rapidly expand and dissolve away.

Specimens to be eaten should be gathered in the young stage and should be cooked promptly; for though not poisonous in the black stage, they are surely not attractive.

Shelley must have had the ink caps in mind when he wrote of the fungi in the garden of "The Sensitive Plant":

"Their mass rotted off them flake by flake, Till the thick stalk stuck like a murderer's stake, Where rags of loose 1lesh yet tremble on high, Infecting the winds that wander by,"

\section{('ō-prî̀'-nuัs}




\section{Shaggy-mane; Horsetail; Maned Agaric (Edible)}

\section{Coprinus comatus (SEE PAGES I, v, viii)}

Cap or Pileus-Cylindrical or barrel-shaped; becoming bell-shaped or expanded, with split margins, when old. Colour of the buttons or young plants dark; but that of the older forms white, flecked with dark patches or scales. Surface shaggy. I $1 / 2-3$ inches long before expansion.

Stem or Stipe-White, smooth, hollow. 3-4 inches long.

Ring or Annulus-Slightly adherent, or movable in the young plant; later lying on the ground at the base of the stem, or wholly disappearing.

Gills or Lamella-Crowded. White, then tinged with pink ; finally black, and dripping an inky fluid.

Spores-Black, elliptical.

Flesh-Fragile, tender, digestible, with nutty flavour.

Time-Autumn.

Habitat-Loose, rich earth. By roadsides, in pastures, and in dumping grounds.

If one study the specimens of the shaggy-mane from the time it pushes its little brown head above the ground until, as a tall black umbrella, it melts away into inky blackness, he will find much that is beautiful and interesting.

A little brown button may be cut with a sharp knife throughout its length to show the unexpanded gills lying close to the part which is afterwards to become the stem.

An older button cut in the same way will show the gills separated from the stem and the outer cover of the cap at the lower end of the gills joined to the stem. A still older specimen will show the connection of the outer cover broken loose from the base of the gill and the torn part still remaining on the stem as a temporary collar.

The outer layer of brown threads which covers the button will be found to break as the threads within expand, and to remain in the older specimens on the surface as patches of brown threads. Underlying these are broken white threads which in a younger stage, unbroken, formed a white cover under the brown. It is these loosely hanging threads which give the shaggy appearance to the cap of the mature plants and which have suggested the names of shaggy-mane, horsetails, and comatus (comatus, in Latin, meaning hairy).

\section{Cō-mä'-tŭs}




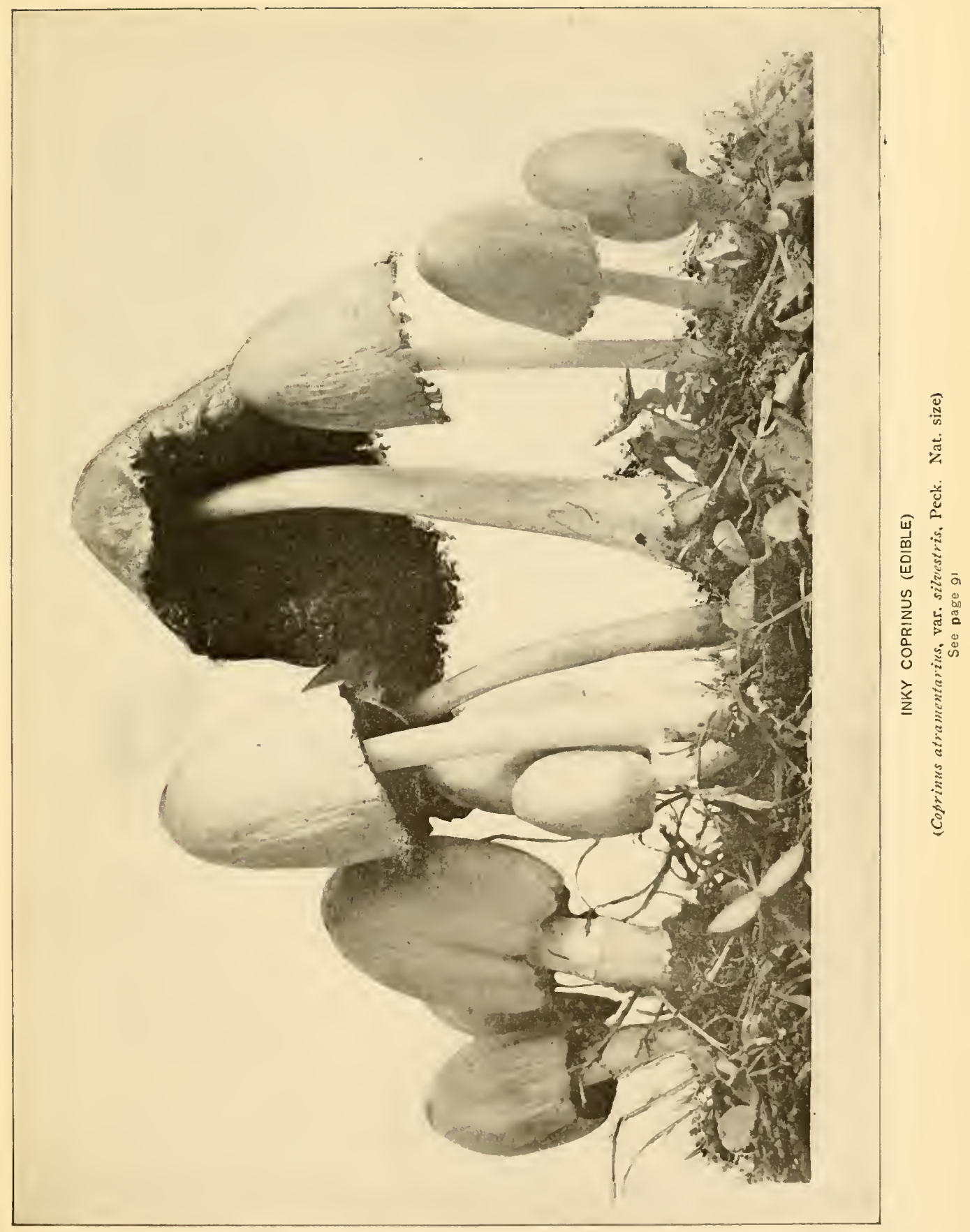





\section{Inky Coprinus (Edible)}

\section{Coprinus atramentarius}

Cap or Pileus-Cylindrical at first, broadening by degrees until it is cone-shaped. Colour greyish or greyish brown, with suggestions of lead colour. Smooth or with a few obscure scales on the disk. Often suffused with bloom. The margin sometimes notched or lobed. Deliquescing. $1-3$ inches in diameter.

Stem or Stipe-Slender, smooth, whitish, hollow.

Ring or Annulus-A slight vestige of one may be seen to extend around the stem near the base as an irregular zigzag elevated line of threads.

Gills or Lamella-Crowded. At first whitish and flocculose on the edges, then black, moist, dropping away in inky fluid.

Spores-Black, elliptical.

Flesh-White, quickly deliquescing.

Time-Autumn.

Habitat-Rich soil, waste places, woods.

The form growing in the woods is much more beautiful and is known as C. atramentarius, var. silvestris. See plate facing page 89 .

\section{Glistening Coprinus (Edible)}

\section{Coprinus micacens}

Cap or Pileus-Ovate, then bell-shaped. Striations radiating from near the centre of the disk to the margin. Glistening mica-like scales cover undisturbed young specimens. I-2 inches broad. Colour tan, light buff, or tawny yellow.

Stem or Stipe-Slender, smooth, fragile, white, hollow. I-3 inches long.

Ring or Annulus-Rarely seen except in very young specimens.

Gills or Lamelle-Not as crowded as in the ink cap and shaggy-

mane. Colour white, then tinged with pinkish or purplish brown, finally black.

Spores-Brown, elliptical.

Flesh-A nutty flavour when raw. In wet weather it melts to an inky fluid. In dry weather it may dry with all parts well preserved.

Time-Common during spring and early autumn.

The glistening coprinus is small and beautiful, and grows in clusters on decaying woods, stumps, or buried roots.

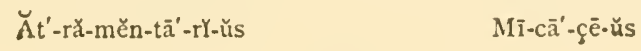




\section{GENUS GOMPHIDIUS}

This genus has black spores. The lamellax are waxy, and grow downward on the stem.

\section{GENUS PSATHYRELLA}

The members of this genus are tleshy fungi, with black spores. They have no annulus, and the lamella are not waxy or decurrent. The cap is striate, and the stem has a hard, tough rind.

\section{GENUS PANAOLUS}

There are six or more species of this genus in America. They have black ovoid spores, a cap smooth and not striate, a fleshy stem.

\section{GENUS LACTARIUS}

A milky or coloured juice exuding from the broken gills of a fungus marks it as a Lactarins. The species are mostly stout and fleshy, the cap resembling an inverted cone; the gills are more or less decurrent, and the stem short and stout. Many of the species have a hot, acrid taste, and some have zones of colour on the surface of the cap. The spores are white or yellow. The juice exuded may be white or orange or blue.

\section{Peppery Lactarius (Edible)}

\section{Lactarius piperatus}

Cap or Pileus-Creamy white, fleshy, firm, depressed in the centre. Dry, never viscid, and uncommonly broald. 3-12 inches in diameter.

Gills or Lamella-Creamy white, narrow, crowded, unequal, forked, decurrent. Exuding a milky juice when bruised. Milk white.

Stem or Stipe-Creamy white, short, thick, solid, rounded at and slightly tapering toward the base.

Gŏın-phYd'-Y-ŭs

Lăc-tä'-rY̌-ŭs
Sā-thȳ-rĕl'-lă

92
J’ăn-æe'-ŏ-lŭs

l’yp ěr-ä'-tŭs 


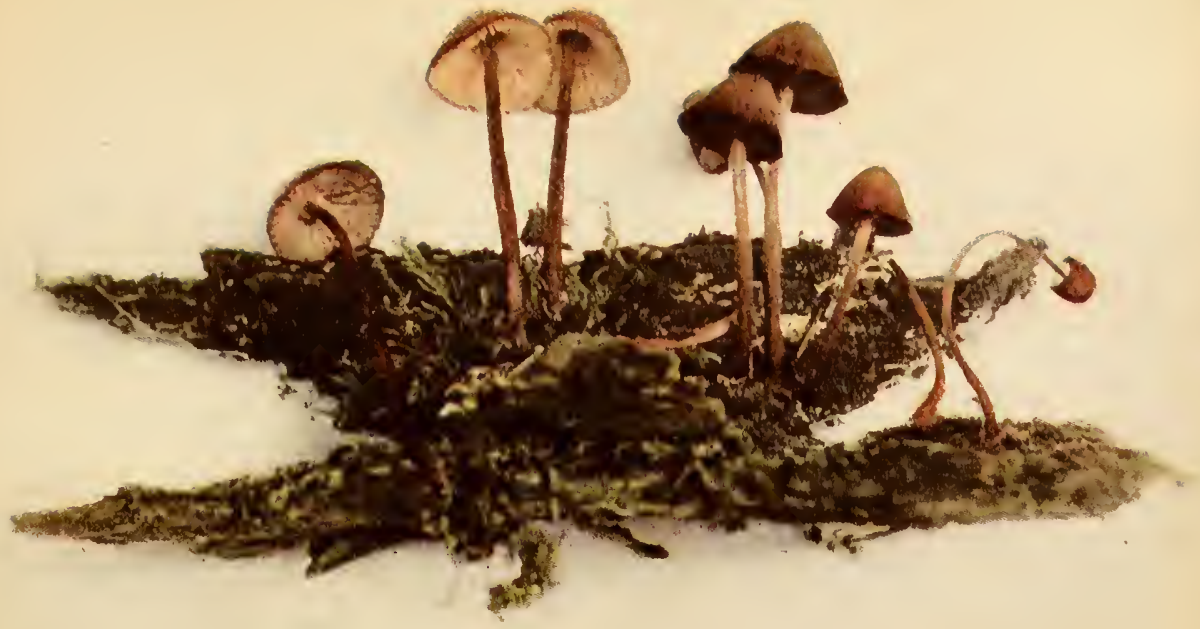

Mycena hæmatopoda, Pers.

See page 55.

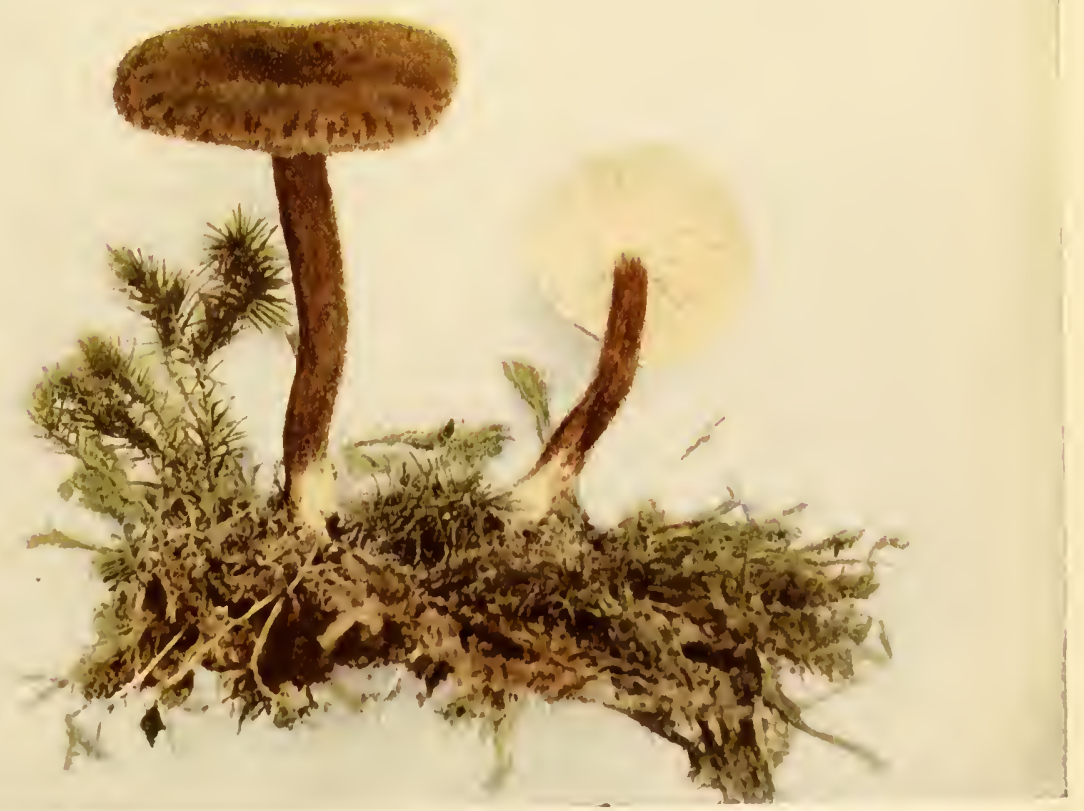

Lactarius IIgniotus, Fr. 




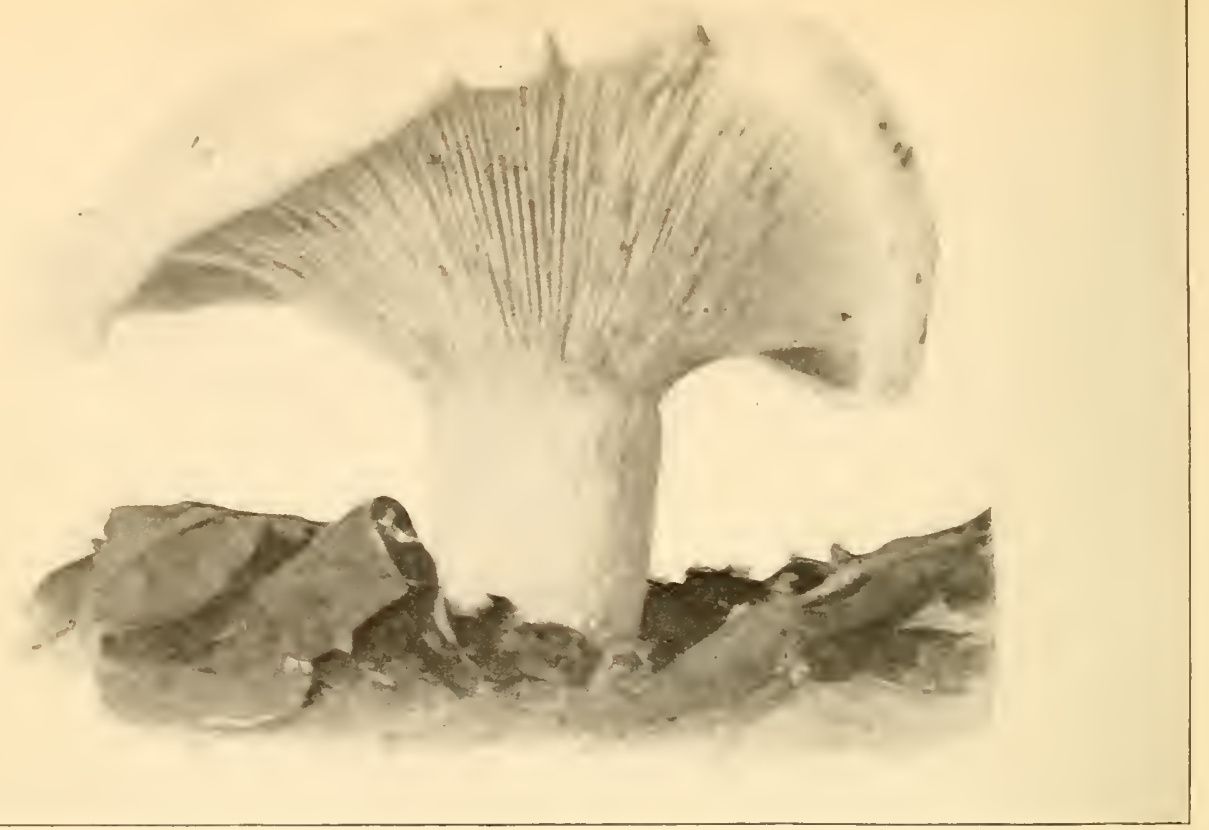

PEPPERY LACTARIUS

(Lactarius piperatus, Scop. Nat. size)

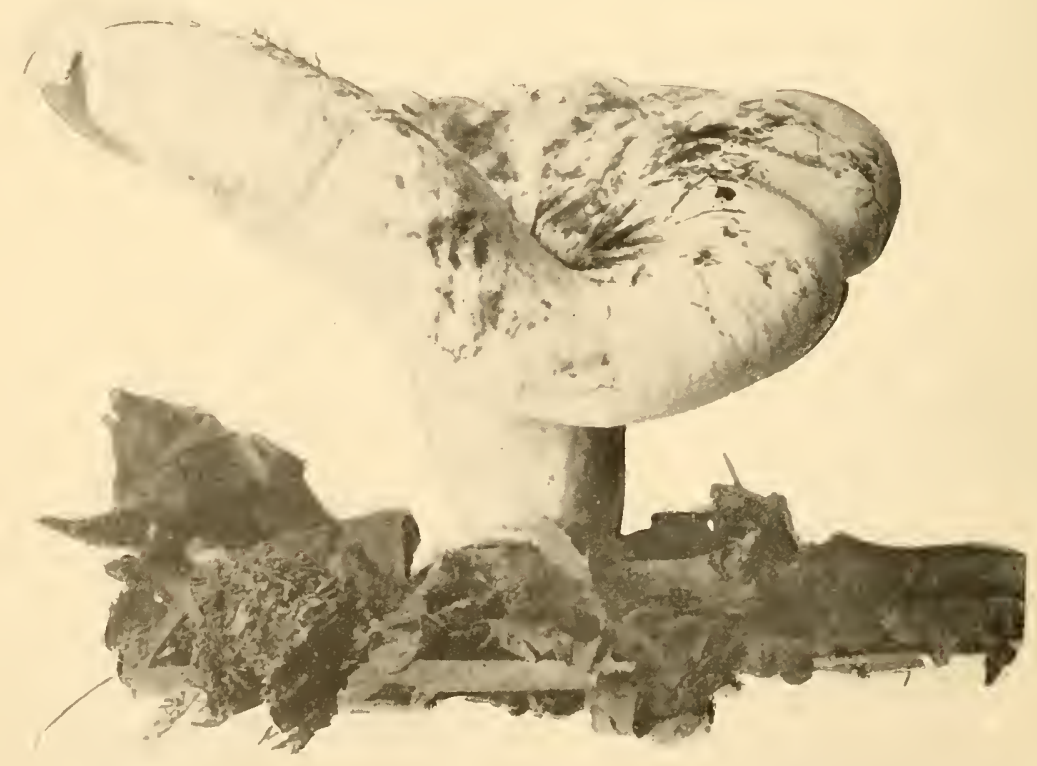

PEPPERY LACTARIUS

(Lactarius piperatus, Scop. Nat, size) 


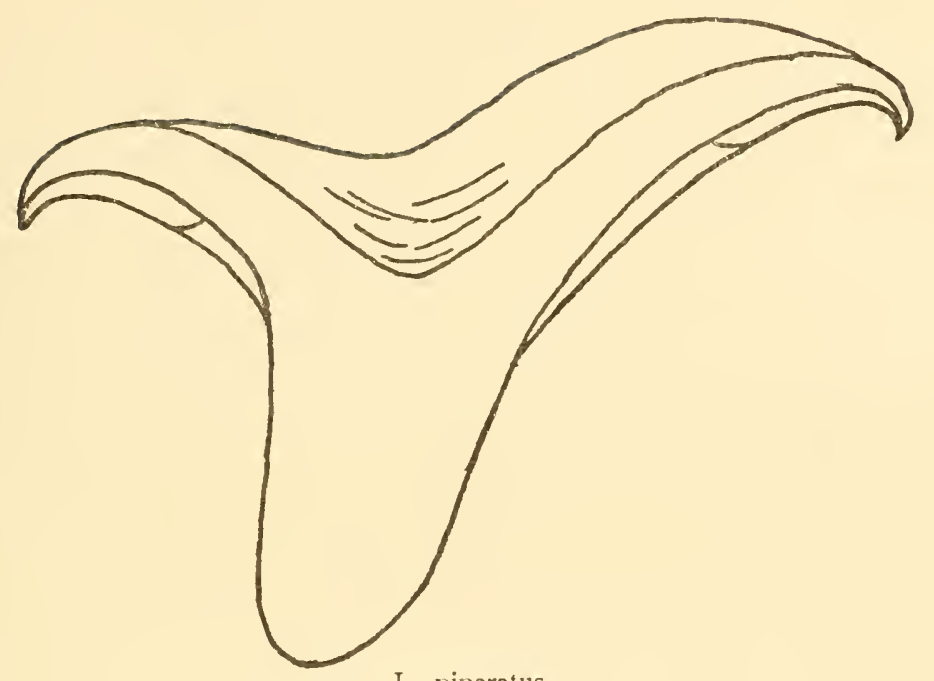

L. piperatus

Veil and Anmulus-None.

Spores-White.

Flesh-Slightly paler than the surface of the cap. Taste very peppery. Odour quite aromatic.

Time-Summer.

Habitat-Specimen pictured was found in mixed woods, among dried leaves and sticks, in New Jersey.

\section{Lactarius ligniotus}

Cap or Pileus-Fleshy; brown velvety surface; convex to plane; brittle.

Gills or Lamella-Attached to the stem, distant, unequal. Snow white to yellowish white. Milk. mild and white.

Stem and Stipe-The upper part the same colour as the cap surface, base lighter; hollow.

Ring or Anmulus-None.

Spores-White.

Flesh-Taste pleasant. Broken tlesh reddish white, then yellow ish.

Time-September.

Habitat-Common among mosses under fir trees. The specimen pictured was found growing in mixed woods at Lake Placid.

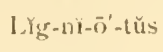




\section{CHAPTER VI: FUNGI WITH TEETH- HYDNACEÆ}

THE fungi with teeth are so called because, instead of bearing their spores on the surface of gills and pores, they bear them on the surface of awl-shaped teeth, which project downward. The genera of the family Hydnacee are distinguished by the size, shape, and attachment of the teeth. Plants with teeth only, and no basal membrane, make the genus Mucronella. Plants with flattened, leaf-like teeth attached to a leathery membrane, growing on wood, either in the form of a cap, or simply spreading over the host, make the genus Irpex. Plants with thick, blunt, irregular spines make the genus Radnlum. Fleshy or membranous plants with caps and flattened teeth, growing on the ground, make the genus Sistotrema. Plants which spread over their host, closely attached to its surface, and have simple, bristle-like teeth, make the genus Pycnodon. Plants growing in a manner similar to those of the genus Pycnodon, but having low-crested wrinkles instead of bristles, make the genus Phlebia; while those with smooth hemispherical warts make the genus Grandinia, and those with crested papillose warts make the genus Odontium. The typical genus Hydnum has the teeth cylindrical, so that a cross section would appear circular. This is the only large genus, and in it are found several important edible species. These may be put in two groups, one containing the species with a cap and central stem, and one the species grcwing in branched masses with no distinct cap. These are commonly known as Hedgehog Mushrooms.

\begin{tabular}{|c|c|c|c|}
\hline Hy̆d-nā'-çĕ-æ & Ir' -pěx & SYs-tō-trē'-mă & Phlĕb-y'-ă \\
\hline 5-něl'-1̆̆ & $\begin{array}{l}\text { Răd'-ů-lŭm } \\
t^{\prime}-Y \text { - } u \text { m }\end{array}$ & 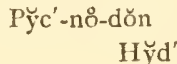 & Grăn-dY'-nY-a \\
\hline
\end{tabular}




\section{GENUS HYDNUM}

\section{Spreading Hydnum (Edible)}

\section{Hydnum repandum (See Plate Facing Page 103)}

Cap or Pileus-Fleshy, fragile, moist, smooth or somewhat scaly in mature specimens. Variable in colour ; light red, pale buff, or rusty yellow. Convex, plane, or deeply concave by the stem becoming hollow. Margins often wavy. 1-4 inches broad.

Teeth or Aculei-Pointed, whitish, easily detached, leaving little cavities in the fleshy cap.

Stem or Stipe-Stem solid in young specimens, hollow in older specimens. Surface rather rough; often eccentric. $\quad 1-3$ inches long.

Flesh-Watery, lighter colour than cap.

Spores-Whitish.

Time-July to October.

Habitat-Woods and open places. Singly or in clusters. The specimen pictured was found in North Carolina in February.

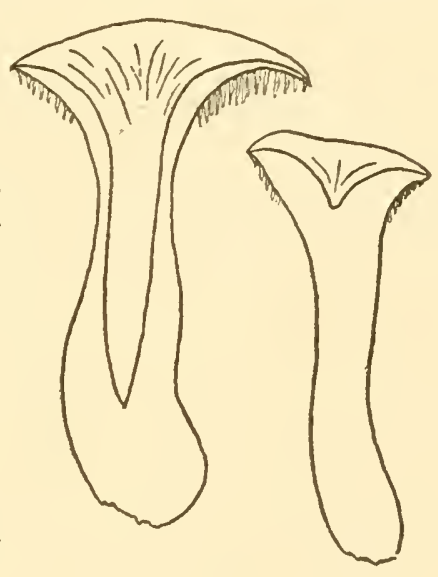

Section of II. repandum

Hydnum rufescens (edible) is redder than the typical form, is smaller and more regular.

\section{White Hydnum (Edible)}

\section{Hydnum albidum}

Cap or Pileus-White, fleshy. 1-2 inches broad.

Teeth or Aculei-White, short.

Stem or Stipe-White, solid, short. I-2 inches long.

Flesh-White.

Time-June to August.

Habitat-Thin, wet woods.

Rë-păn'-dŭm

Rū-fĕs'-ç̌̌ns

Ăl-br'-dŭm 


\section{Hydnum imbricatum}

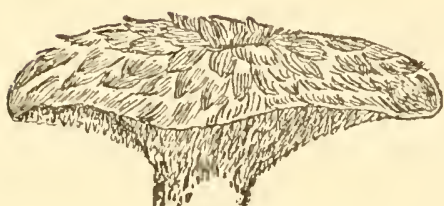

11. imbricatum

Cap or Pileus-Brownish, as if scorched. Surface cracked in irregular scales. $6-7$ inches wide.

Teeth-Bluish grey.

Stem or Stipe-Short and thick, with irregular scales.

Flesh-Whitish.

Time-Late summer.

Habitat-Dry woods.

\section{Bear's-head Hydnum (Edible)}

\section{Hydnum caput-ursi}

Plant-White, fleshy.

Branches and Teeth-Short branches covered with awl-shaped teeth of varying length, pointed toward the ground.

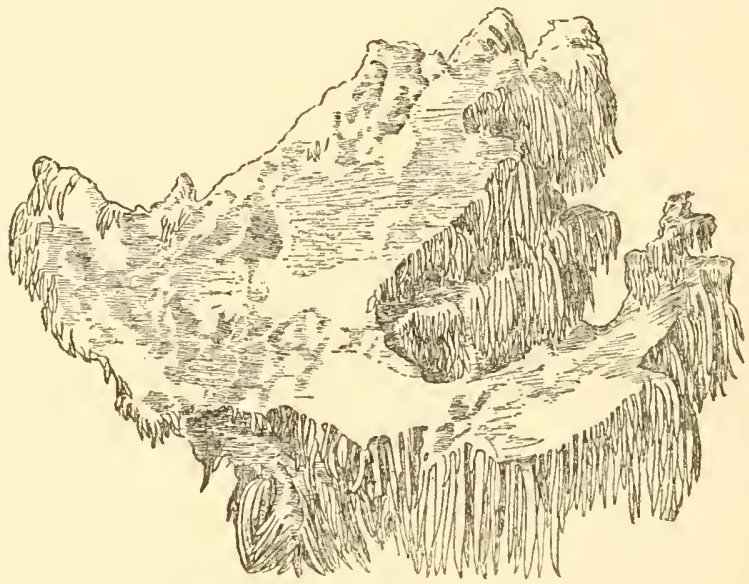

Section of $H$. caput-ursi

Flesh-White when young, creamy when old.

Habitat-On prostrate or standing tree trunks of decaying deciduous trees. Erect, if on the upper side; ascending or pendulous or both, if on the side of the trunk.

The bear's-head hydnum is very variable in form. The İm-brr-cā'-tŭm Că'-pŭt-ŭr'-sī 


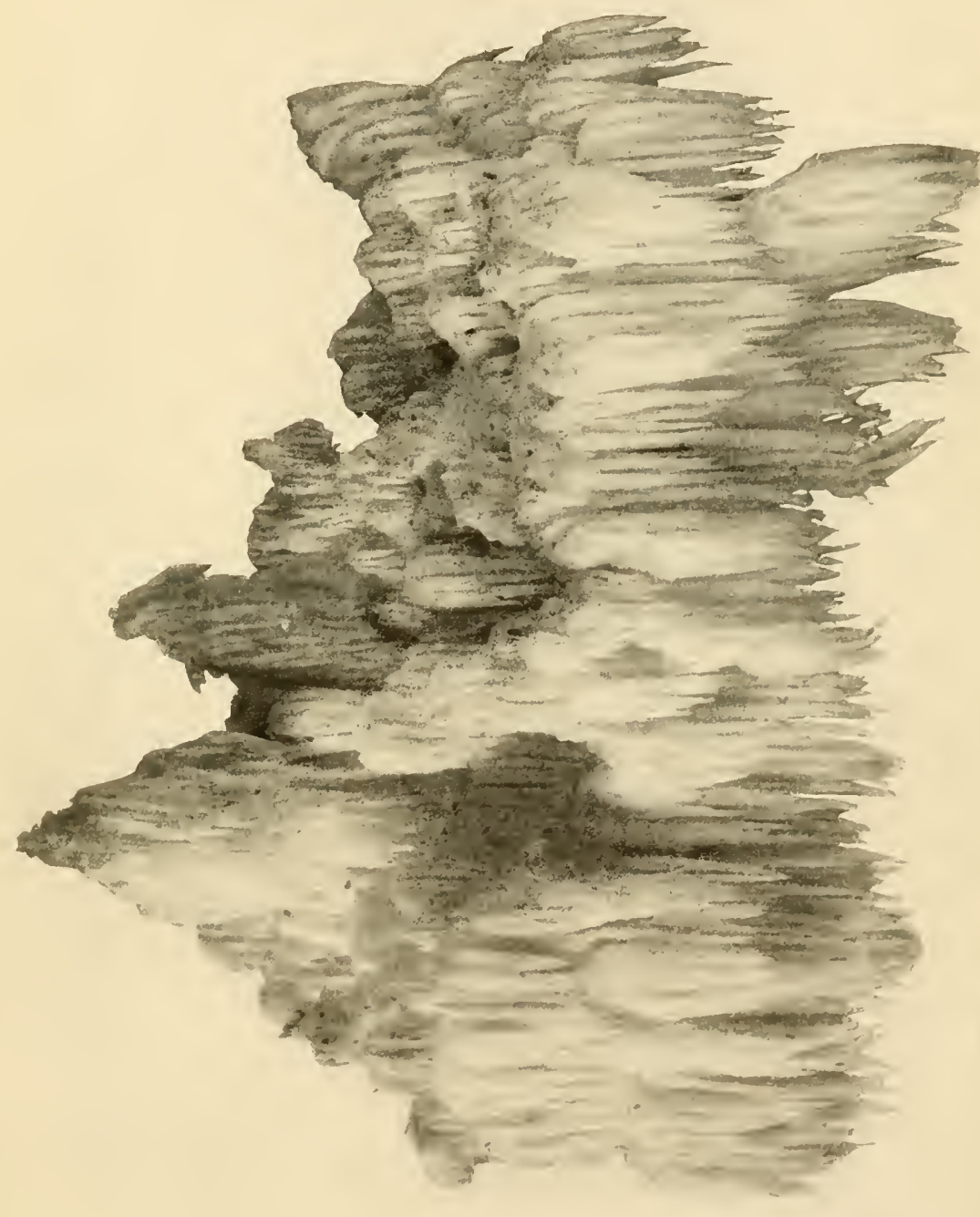

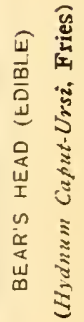






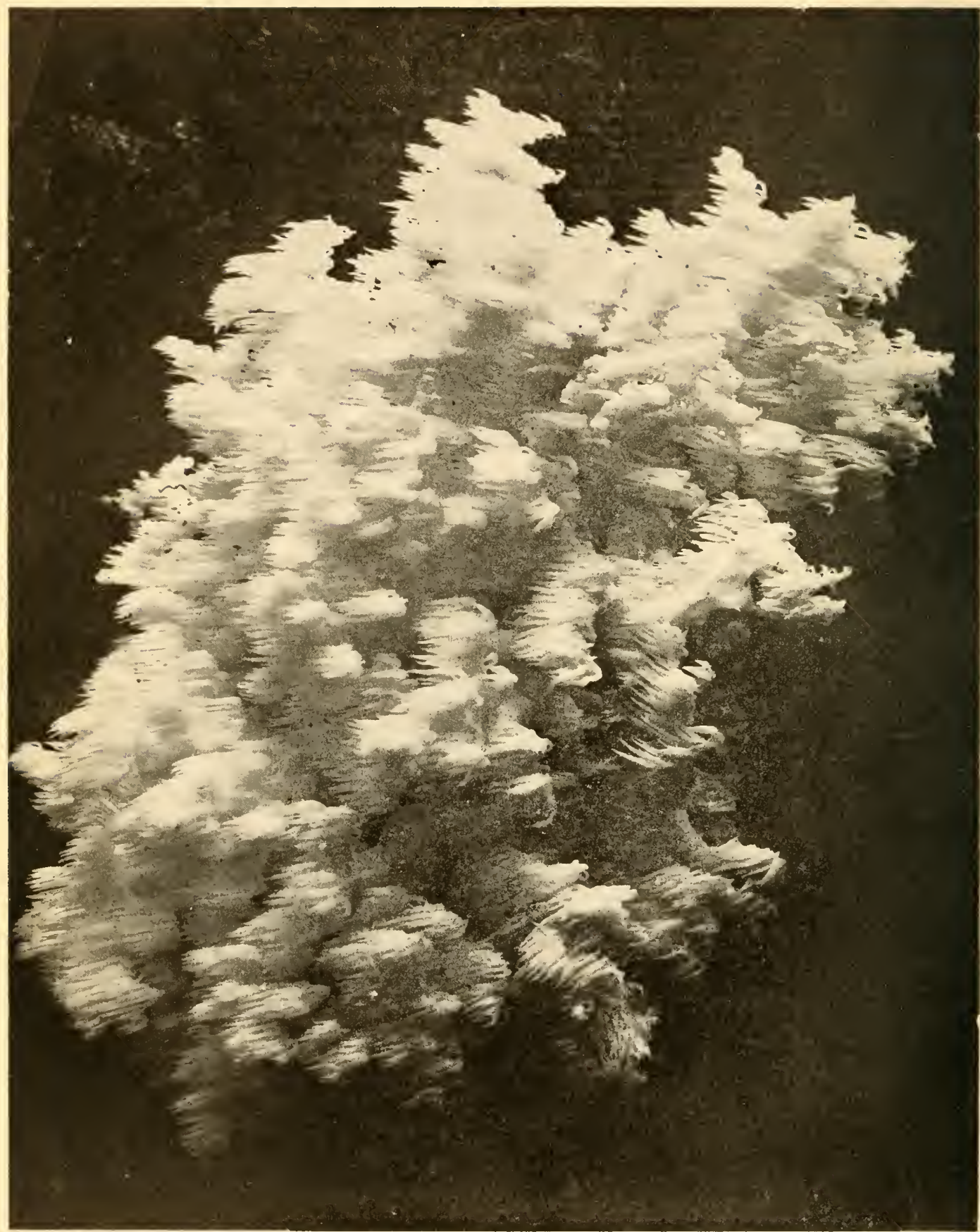


essential character is a solid, fleshy body with short protecting branches bearing numerous simple or branched teeth, which may vary in length from one-sixth of an inch to two inches.

\section{Medusa's Head (Edible)}

\section{Hydnum caput-medusce}

Hydnum caput-medusa has knob-like branches, with short, distorted teeth above, and long, uniform ones below. At first it is white, but later changes to a smoky or ash colour. The change in colour from white to an ashy tint distinguishes it from $H$. caput-ursi, which changes to creamy white.

\section{Hedgehog Hydnum (Edible)}

\section{Hydnum echinacens}

The hedgehog hydnum is white at first, and then creamy. The branches are knob-like, and bear numerous straight, equal teeth about two inches long.

\section{Coral Hydnum (Edible)}

\section{Hydnum coralloides}

Plant-Pure white, becoming creamy with age.

Branches and Teeth-Numerous, spreading, angular or flattened.

Terminal branches often curved upwards, terminating in a

crowded mass of spines. Teeth, $1 / 6-1 / 3$ of an inch long. Stem-Short, dividing into branches almost from the base. Flesh-Tender, white, with agreeable taste.

Time-July to October.

Habitat-On prostrate trees in mountainous or hilly country.

When a mere child, Elias Fries was so attracted by this beautiful coral-like fungus, which grew in his native forests in Sweden, that he was led to take up the study of fungi, and later became one of the most prominent students in that branch of botany, and latid the foundation for the study of the Basidiomicetes.

$$
\text { Că'-pŭt-mē-dū'-sà Ëch-ĩ-nā'-çěr-ŭs Cơr-ăl-loi'-dès }
$$




\section{CHAPTER VII: FAIRY CLUBS AND CORAL FUNGI-CLAVARIACEÆ}

THE fairy clubs and coral fungi belong to the family Clava. riacece. They are fleshy fungi of upright growth, which have their spore-bearing surface exposed on the apices of branching or simple club-like forms. Many are extremely beautiful, resembling corals of exquisite shades of pink, violet, yellow, or white.

The seven genera are distinguished by the colour of the spores, by their habit of growth-whether simple or branched, and, if branching, by the form of the branches; whether clublike or thread-like, flat or round, cartilaginous or leathery. Many of the members of this family are edible, and none are known to be unwholesome, so that it will be safe for a beginner to try any of them.

\section{GENUS PHYSALACRIA}

Plant small, simple, hollow, and enlarged at the apex.

\section{GENUS PISTILLARIA}

Plants conspicuous, club-shaped or thread-like, with two spicules to each spore-bearing cell.

\section{GENUS TYPHULA}

Plants conspicuous, club-shaped or thread-like, with four spicules to each spore-bearing cell.

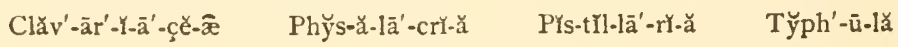




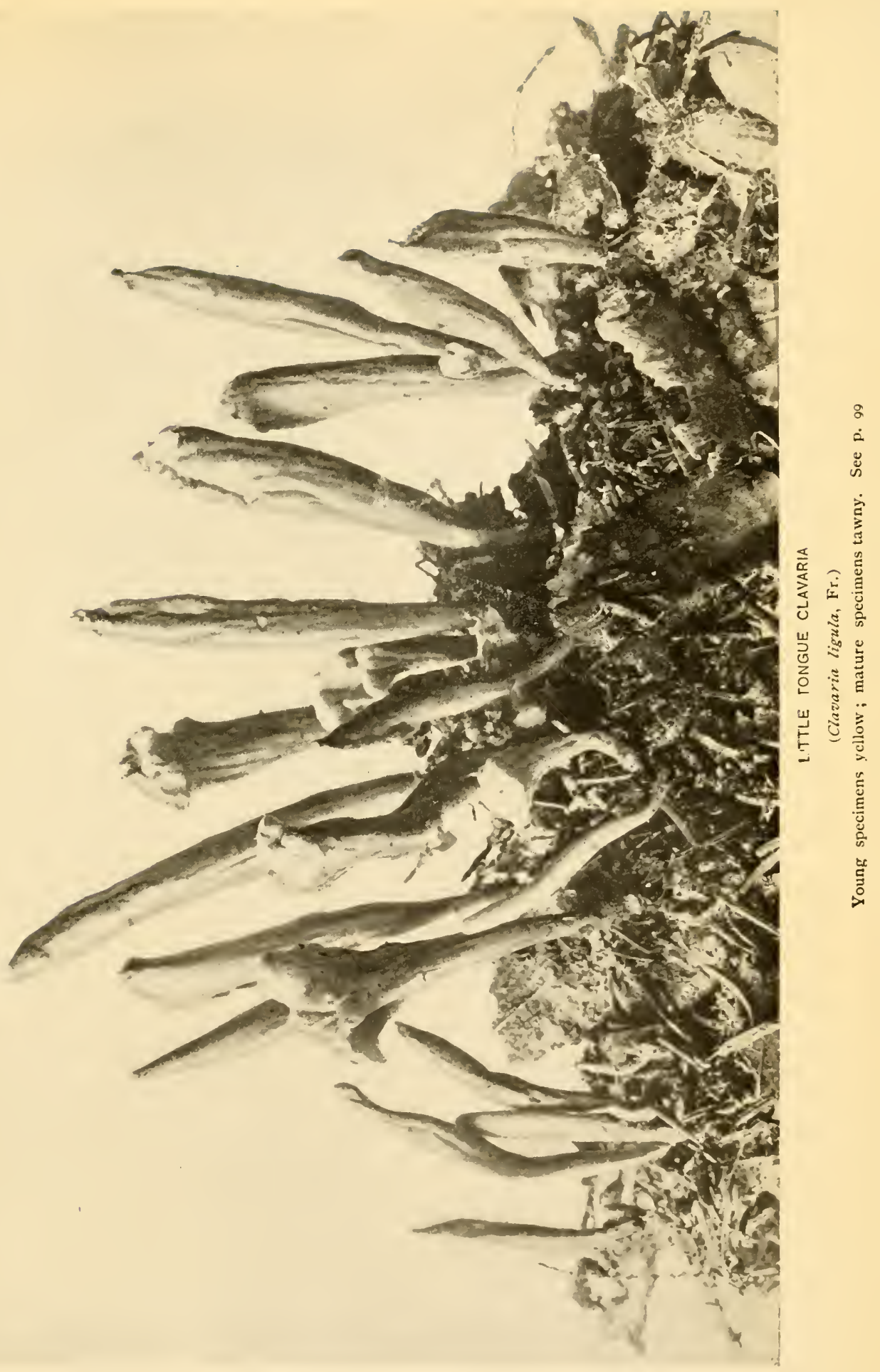





\section{GENUS SPARASSIS}

Plants conspicuous, with the branches strongly flattened or leaf-like.

Sparassis crispa somewhat resembles a yellow cauliflower, and often forms masses as large as one's hand. It is considered an excellent fungus for the table.

\section{GENUS PTERULA}

The members of this genus are mostly slender, thread-like forms, cartilaginous when moist, and horny when dry.

\section{GENUS LACHNOCLADIUM}

The members of this genus are leathery plants covered with hairs.

\section{GENUS CLAVARIA}

The genus Clavaria is the largest genus in the family Clavariacece. Many of the species are edible, and so easily recognised that the beginner may venture without hesitation to eat any of the branching forms. The club-like forms might be mistaken for certain club-shaped forms of the sac-fungi unless an examination of the spores were made. The Clavarias would have the spores on little spicules, as in the garden mushroom, whereas the forms for which they might be mistaken would have them in membranous sacs.

In collecting species of Clavaria, notes should be taken as to the character of the apices of the branches, the colour of the branches, the colour of the spores, the taste, and the place of growth.

\section{Pale Yellow Clavaria (Edible)}

\section{Clavaria flava}

Plant-White and pale yellow. 2-5 inches high; the mass of branches $2-5$ inches wide.

Spā-răs'-sYs CrYs'-pă Těr'-ŭ-lă Lăk-nǒ-clā'-dY-ŭm Clăv-ār'-1-ă Flāv'-ă 
Branches-Round, not flattened; smooth, crowded, and nearly parallel, pointing upward. Whitish or yellowish, with pale yellow tips. Branchlets terminating in from one to three blunt, tooth-like points.

Stem-Short, thick, white.

Spores-Yellowish.

Flesh-White, tender.

Time-July to September.

Habitat-Thin woods and open places.

\section{Golden Clavaria (Edible)}

\section{Clavaria anrea}

The plant is from three to four inches high, with the branches of a uniform deep golden yellow, and often longitudinally wrinkled. The stem is stout, but thinner than the Clavaria flava, which it somewhat resembles.

\section{Red-tipped Clavaria (Edible)}

\section{Clavaria botrytes}

Plant-From 2-5 inches high, whitish or yellow or pinkish, with the tips of the branches red.

Branches - Sometimes longitudinally wrinkled, repeatedly branched.

Stem-Short, thick, fleshy, whitish.

Time-July to September.

Habitat-Thin woods and open places.

\section{Crested Clavaria (Edible)}

\section{Clavaria cristata}

Plant-Small, not more than $2-2 \frac{1}{2}$ inches high. White or whitish, often faintly tinged with dull pink, or creamy yellow, or smoky tints.

Branches-Widened and flattened above, and deeply cut into several finger-like points, which may turn blackish brown when old.

Stem-Slender, spongy within.

Spores-White.

Habitat-Woods and open places, especially in cool, shady, moist places.

$$
\text { Au'-rĕ-ă }
$$




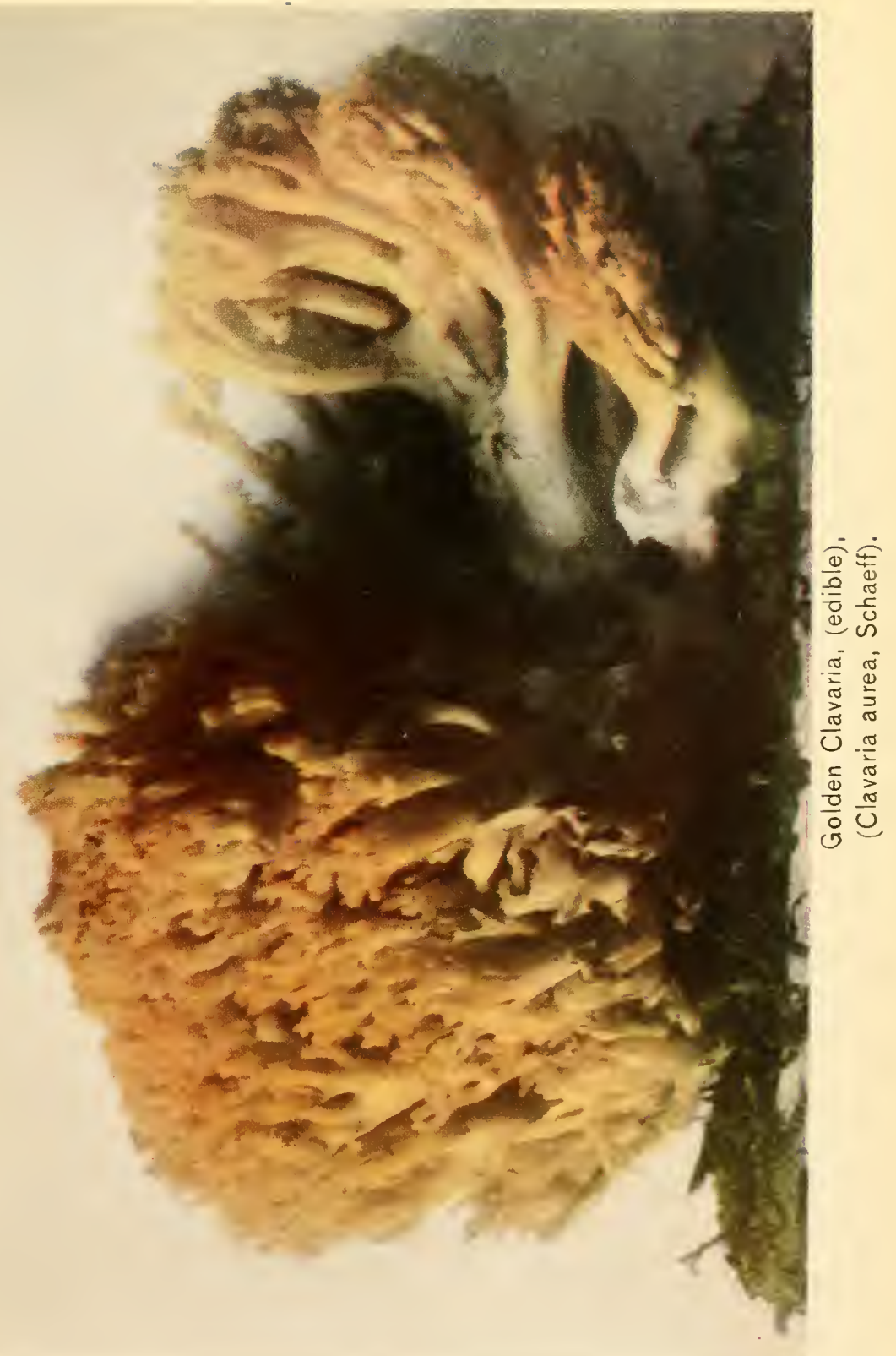





\section{Pistil Clavaria; Large Club (Edible)}

\section{Clavaria pistillaris}

Of the club-shaped clavarias, the pistil clavaria is the largest. It is of a light yellow tinged with brown or red, and with soft white flesh. In shape it resembles an Indian club, being blunt and rounded at the summit, with a diameter of an inch or less, and a height of tive inches or less. It is found during the summer in grassy open places or in thin woods.

\section{Clavaria fellea}

The clubs of this species are about one inch high, light yellow tinged with brown or red, somewhat divided by pairs from bottom to top into two forked branches. The stem is round and solid, and the branches are crowded and nearly parallel, with blunt tips, and of a uniform colour. The taste is bitter.

\section{Clavaria formosa}

The Clavaria formosa has a stout whitish stem, with erect branches, dividing and subdividing repeatedly, golden to pink, the branchlets obtuse. The specimen pictured grew on a fallen tree in dense mixed woods.

$$
\text { Prs'-trll-lā'-rĭs Fěrl'-lě-ă } \quad \text { Fŏr-mō'-să }
$$




\section{CHAPTER VIII: FUNGI WITH PORES- BOLETACEÆ; POLYPORACEÆ}

THE fungi with pores naturally divide into two groups. The perishable fleshy fungi with pores easily separating from the cap and from each other make the family Boletaceo. The perishable fleshy fungi, and the leathery, corky, membranous or woody fungi, with pores permanently united to the cap and

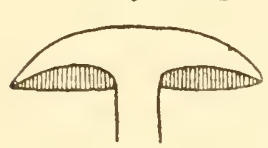

to each other, make up the family Polyporaced. In each the spores are borne on the linings of pores or tubes placed close Section of a Boletus together, so that on the surface of the cap they look much like large pin pricks on a stiff cushion; but in a sectional view, obtained by cutting the cap from the upper surface to the lower, they look like tubes placed side by side.

Among the fleshy forms the genus Fistulina has the stem lateral and the tubes close together, but distinct from each other. The genus Boletus has the tubes easily separable from the cap, and the genera Boletimus and Strobilomyces have the tubes quite firmly connected. A brief comparison of essential points is given in the table.

1. Stem strictly lateral. Mouths of the tubes separated from

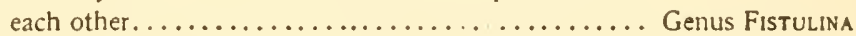

2. Stem central. Pores readily separating from the cap..... Genus Boletus

3. Stem central or eccentric; fleshy. Pores in more or less

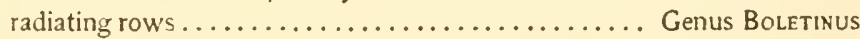

4. Stem central, tough. Pores uniform. Cap woody...... Genus Srrobllomyces

\section{GENUS FISTULINA}

The genus Fistulina contains one notable species, Fistulina hepatica, so called from its resemblance to a liver. In its early stages it somewhat resembles a strawberry, and later it may

\begin{tabular}{|c|c|}
\hline Bō-lē-tā'-çěere & FYs-tŭ-1r̃'-nă \\
\hline Pō'-ly̆-pǒ-rā'-çĕ-æ & Bŏ-lē'-tŭs \\
\hline
\end{tabular}


have the appearance of a big red tongue protruding from a tree trunk, so that the French call it langue de bouf. It is often called vegetable beefsteak, from the flesh-like fibre and colour of the fresh specimens. When young, the upper side is velvety and of a fine peach colour; later it becomes liver red and loses the velvety appearance; the under surface is flesh coloured, and is rough, much like the surface of a tongue, owing to the fact that the tubes are free from one another.

\section{GENUS BOLETINUS}

The spore-bearing surface of the genus Boletinus is composed of broad, radiating lamellæ connected by numerous narrow partitions so as to form large angular pores. The tubes are not easily separable from each other and from the portion on which they are borne. They are yellowish in colour, and grow downward somewhat on the stem. The genera may be distinguished by the following table:

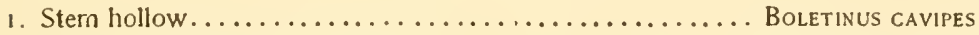

2. Stem solid, lateral, or eccentric.................... Boletinus porosus

3. Stem solid, central. Cap pale yellow and silky........... Boletinus Decipiens

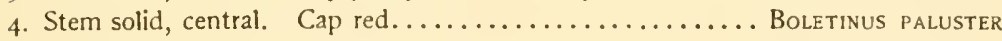

5. Stem solid, central. Cap with red scales............. Boletinus pictus

\section{Painted Boletinus (Edible)}

\section{Boletinus pictus}

Cap or Pileus-Convex or nearly plane; at first covered with red matted fibres, which soon divide into small scales, so as to reveal the yellow colour of the cap beneath. 2-4 inches wide. Tulies-Pale yellow, or pale yellow tinged with brown. Not easily separated from the cap.

Veil-Webby, concealing the tubes of the young plant.

Stem or Stipe-Solid, with scales and colour similar to those of the cap. $1 \frac{1}{2}-3$ inches long.

Ring or Annulus.-Webby; evident in some specimens.

Spores-Pale yellow tinged with brown.

Flesh-Yellowish, often assuming reddish tints when bruised.

Habitat-Woods and mossy swamps.

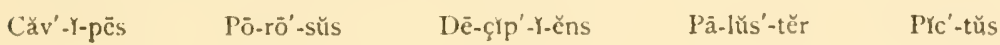




\section{GENUS BOLETUS}

The species in the genus Boletus are numerous, and many are extremely beautiful. They are distinguished from the other pore-bearing fungi by the fact that their tubes are easily separable from each other and from the portion on which they are borne.

They are to be looked for in the warmest part of the season, and with al few exceptions will be found on the ground. As it is difficult to dry specimens so that they will retain their size, shape, and colour, careful notes should be taken of these points, together with the colour of the spores, the colour of the tubes, the colour of the flesh before and after being bruised, the character of the stem, the presence or absence of hairs and fibres on the several parts of the plant. The genus Bolefus contains many edible species, and also many which are dangerous; and as the recognition of the different species is a difficult matter, even for experts, the beginner should be especially cautious. In general it will be well to alvoid for edible purposes all Boleti which change colour on exposure to the air or on being pressed; all those which have red-mouthed tubes, or mouths of a deeper colour than the rest of the tube; and all those with a peppery or acrid taste. Experiment cautiously with the other species.

A detailed description of the species is out of the question in this book; for such the reader must refer to "Boleti of the United States,"* or to "Führer für Pilzfreunde." $\dagger$

\section{Boletus glabelius}

Cap-Smoky yellow.

Flesh-White, changing to blue when wounded.

Tubes-Brownish yellow tinged with green, changing to blue when wounded.

Stem-Reddish at the base, pallid above, with a narrow reddish circunscribing zone or line at the top. Habitat-Grassy ground.

\section{Glā-běl'-lŭs}

* Bulletin, New York State Museum, No. S, r8SS. This can be obtained at a small price of the State Librarian at Albany, New York. In it are described one hundred and ten species.

$\nmid$ By Edmund Michael. A book in German, with sixty-eight coloured plates. 


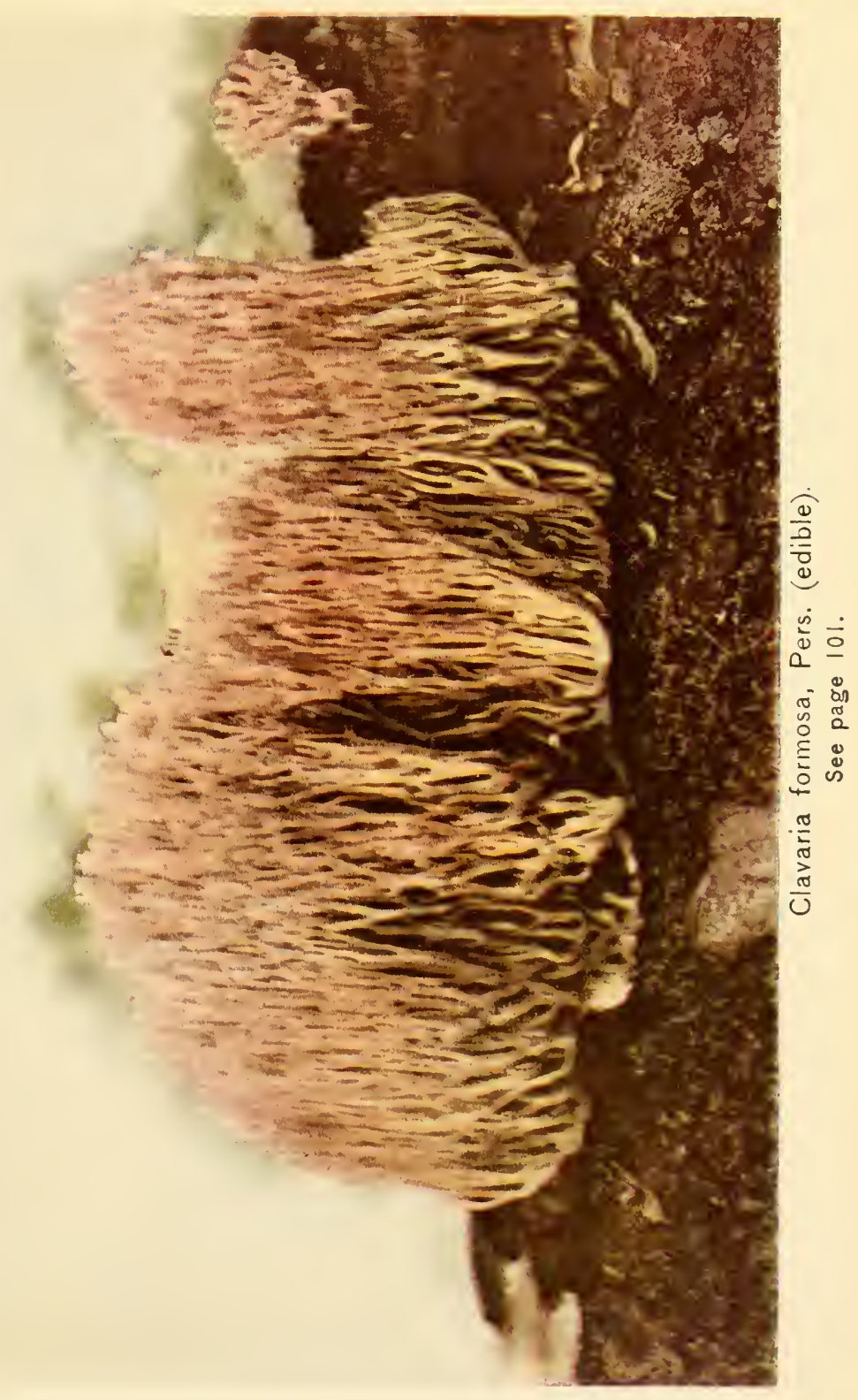





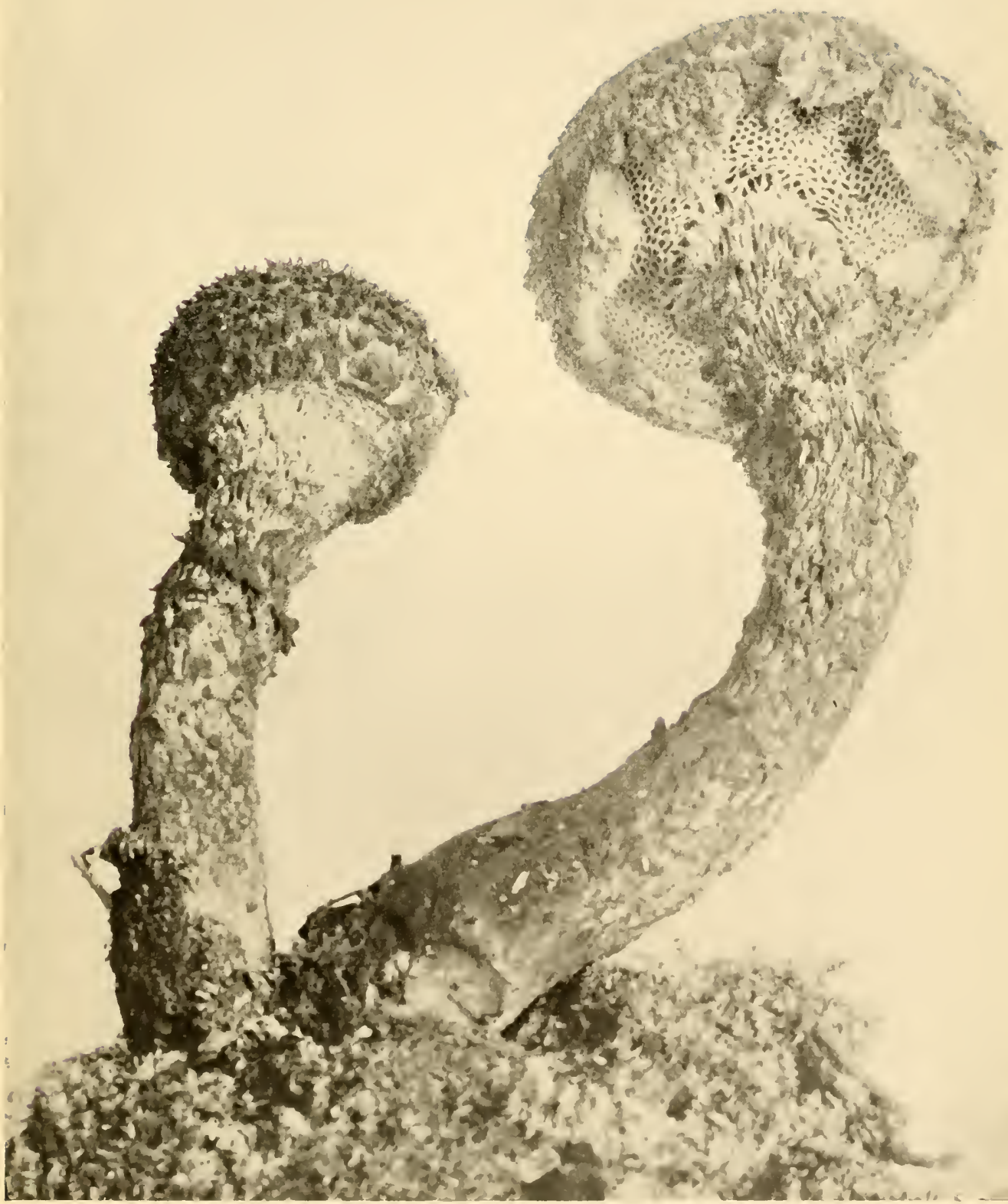

CONE-LIKE BOLETUS (EDIBLE, MCI.)

(Strobilomycrs strobilace'us, Berk.)

Purplish black; flesh white, changing to red when bruised. See p. 102 




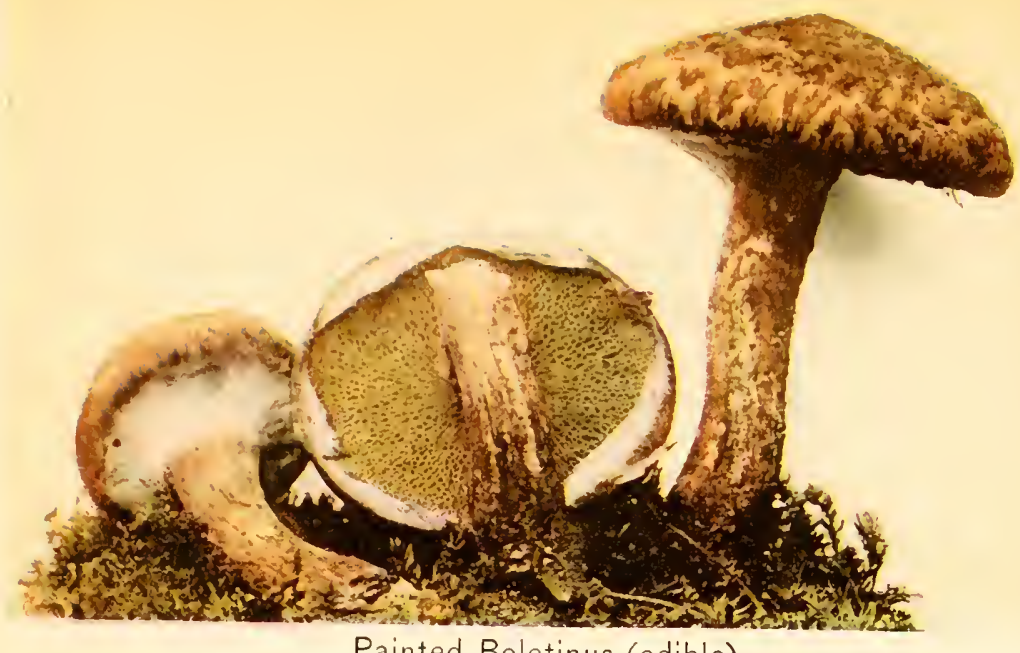

Painted Boletinus (edible).

(Boletinus pictus, Pk.).

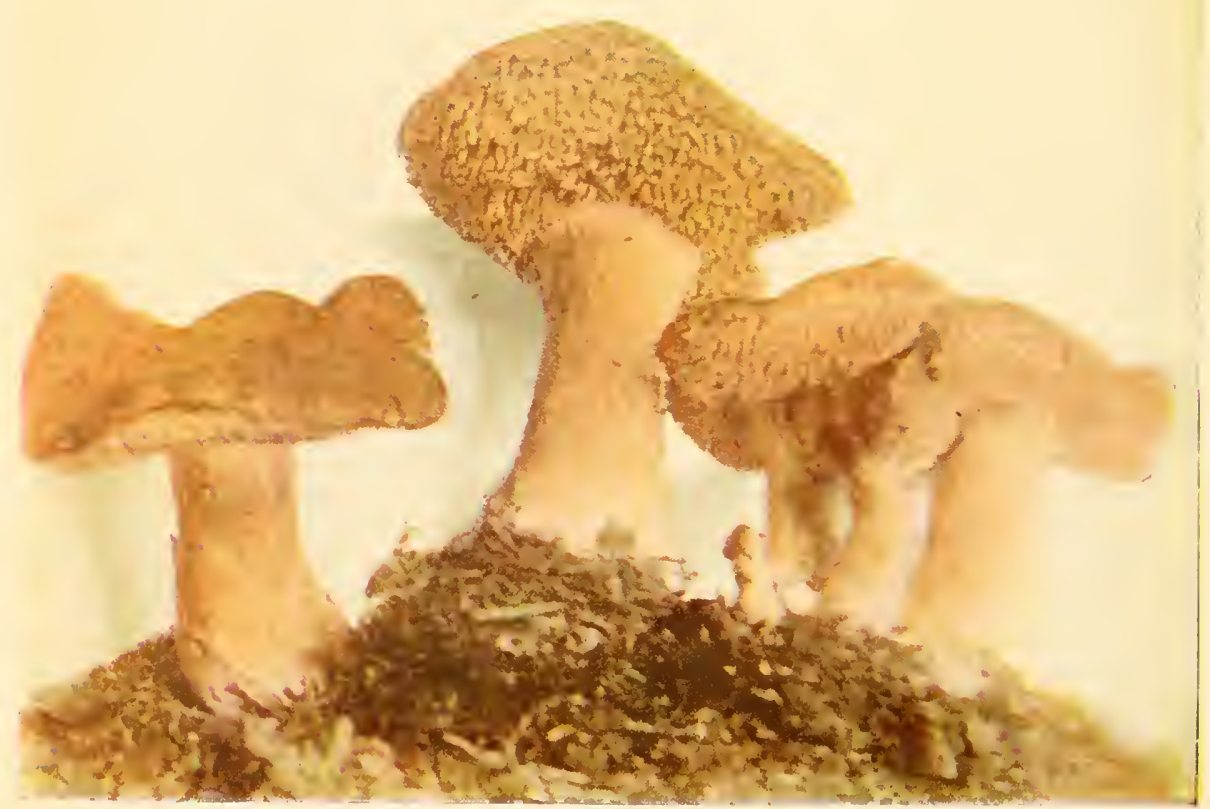

Spreading Hydnum (edible).

(Hydnum repandum, L.).

See page 95. 


\section{Boletus bicolor}

Cap-Dark red, fading when old ; often marked with yellow. Flesh-Yellow, slowly changing to blue when wounded.

Tubes-Bright yellow, changing to blue.

Stem-Solid, red, generally yellow at the top.

Habitat-Woods and open places.

\section{Boletus cyanescens}

Cap-Pale buff or greyish yellow. Covered with woolly scales, two-fifths of an inch wide.

Flesh-White, quickly changing to blue when wounded.

Tubes-White, becoming yellowish, changing to blue when bruised.

Stem-Coloured like the cap. Swollen, stuffed, not covered with a network.

Habitat-Woods and open places.

\section{Boletus pallidus}

Cap-Pallid or brownish white, sometimes tinged with red.

Flcsh-White.

Tubes-Pale whitish yellow, changing to blue when wounded.

Stcm-Long and whitish, sometimes streaked with brown; smooth.

\section{Boletus mutabilis}

Cap-Brown, becoming blackish ; smooth and shining; or dry, somewhat woolly.

Flesh-Bright yellow, promptly changing to blue when wounded. Tubes-Yellow, changing to greenish yellow, and quickly becoming blue when wounded. Mouths large and angular.

Stcm-Stout, bright yellow within, covered with brown and dotted scales.

Habitat-Dense woods.

\section{Boletus speciosus}

Cap-Red. 3-7 inches broad.

Flesh-Pale or bright lemon yellow, changing lo blue when wounded.

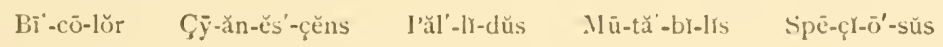


Tubes-Bright lemon yellow, becoming dingy yellow with age; changing to green, then to blue. when wounded.

Stem-Bright lemon yellow without and within, sometimes reddish at the base. $2-4$ inches long.

Habitat-Thin woods.

\section{Golden-flesh Boletus}

Boletus chrysenteron (See Plate Facing Page 60)

Cap-Yellowish brown, reddish brown, brick red, or olive tinted with reddish chinks.

Flesh-Yellow, red just under the skin, of ten changing to blue when wounded.

Tubes-Greenish yellow, changing to blue when wounded.

Stem-Red or pale yellow.

Habitat-Woods or mossy banks, common.

\section{Boletus radicans}

Cap-Dry, somewhat woolly. Greenish grey, becoming pale yellow. Margin rolled under.

Flesh-Pale yellow, instantly changing to dark blue when wounded. Tubes-Lemon yellow.

Stem-Tapering downward and rooting. Woolly, with a reddish bloom. Pale yellow, becoming dark with a touch. Habitat-Woods, Ohio.

\section{Boletus Peckii}

Cap-Firm, dry. Red, fading to yellowish red or buff brown. Tubes-Yellow, changing to blue when wounded.

Stem-Red; yellow at the top.

Habitat-Woods.

\section{Boletus calopus}

Cap-Olive tinted, somewhat woolly. 2-3 inches wide. Flesh-Pallid, slightly changing to blute when wounded.

Tubes-Yellow.

Stem-Covered with a network. Wholly scarlet, or at the apex only. Longer than the diameter of the cap. Habitat-Woods. 



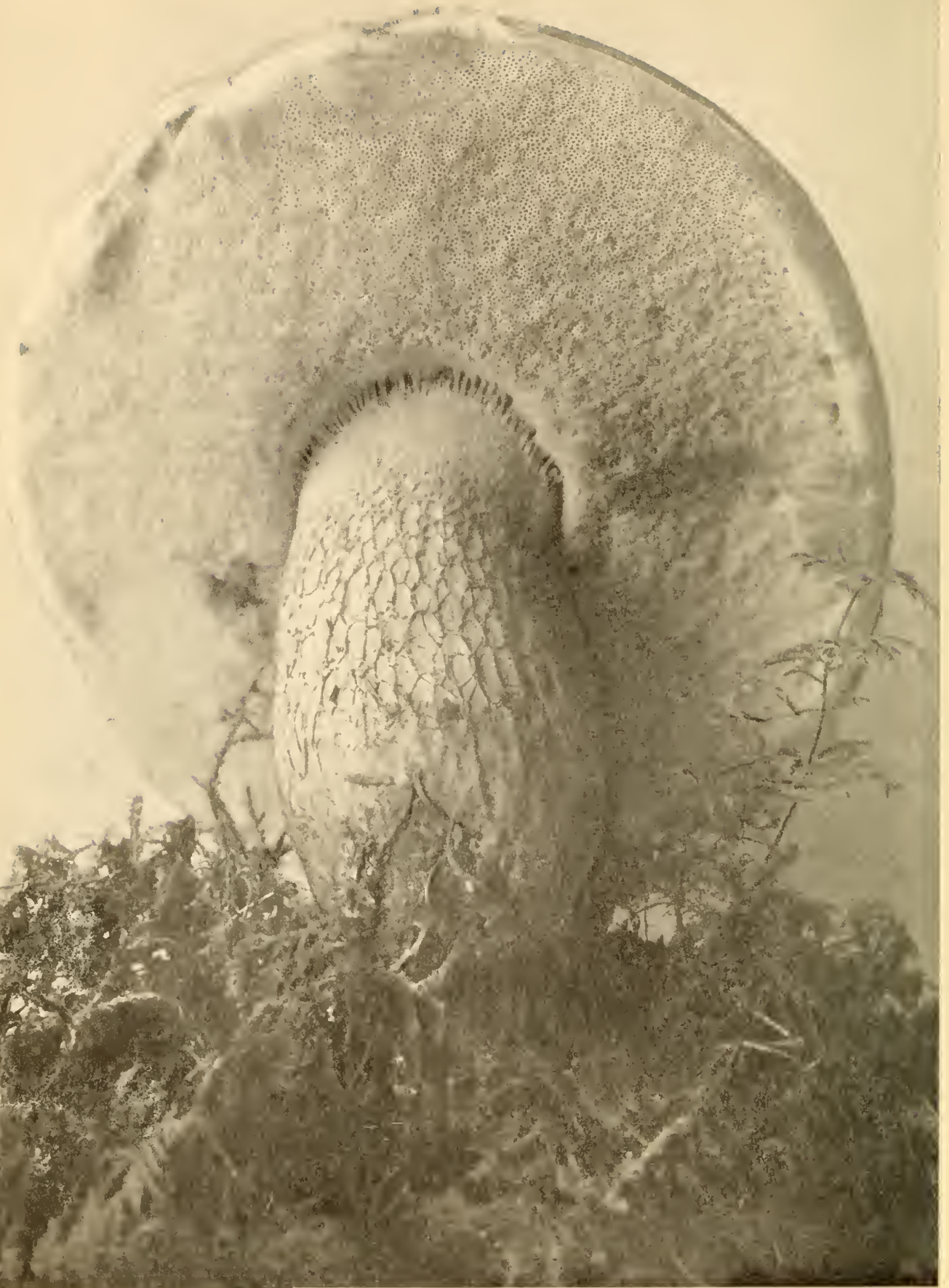

BITTER BOLETUS (UNPALATABLE)

(Boletus felleus, Bull.; var, obesus, Pk.). See p. 107 


\section{Purple Boletus}

\section{Boletus purpureus}

Cap-Dry, velvety. Purple red.

Flcsh-Changing to blue, and then to dark yellow in the young plant.

Tubes-Yellow or greenish yellow. Mouths minute, orange tinged with purple, changing to blue where wounded.

Stem-Stout, with purple veins or dots. Apex sometimes covered with a network. Yellow, reddish within.

Habitat-Woods.

\section{Boletus Satanus}

Cap-Smooth, somewhat sticky.

Pale brown or whitish. $3^{-8}$ inches broad.

Flesh-Whitish, becoming reddish or violet when wounded. Very poisonolis.

Tubes-Yellow. Mouths brightred, becoming orange.

Stem-Thick, swollen, marked above with a red network. $2-3$ inches long.

Habitat-Woods.

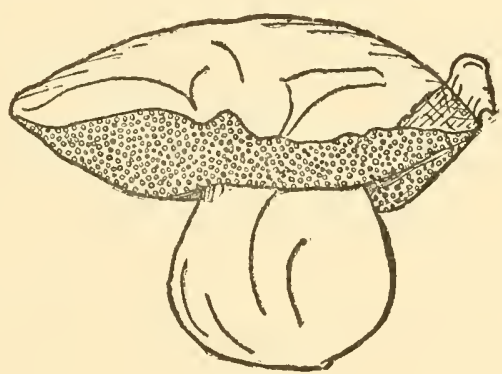

B. Satanus

\section{Bitter Boletus}

\section{Boletus felleus}

Cap-Smooth, pale yellowish, greyish brown, yellowish brown, reddish brown, or chestnut. 3-8 inches broad.

Flesh-White, changing to flesh colour when bruised. Taste bitter.

Tubes-White, becoming flesh colour. Mouths angular. Adnate to the stem.

Stem-Covered with network. Colour similar to the cap. 2-4 inches long.

Habitat-Woods and open places.

Pŭr-pü'-rĕ-ŭs

Fěl'-lē-ŭs 


\section{Boletus scaber}

Cap-Smooth, viscid when moist, or minutely woolly, velvety, or scaly. 1-5 inches wide. Colour ranges from nearly white to almost black.

Tubes-Free from the stem, white, long. Mouths minute. Flesh-White.

Stem-Long, ground colour whitish, roughened with blackish brown or reddish dots or scales. 3-5 inches long.

Habitat-Common in woods, swampy and open places.

\section{Orange-cap Boletus}

Boletus versipellis

Cap-Orange red. 2-6 inches wide. Dry, minutely woolly, then scaly or smooth. Margin edged with the remains of the veil.

Flesh-White or greyish.

Tubes-Long. Mouths minute. Greyish-white.

Stem-Solid; white scaly wrinkles. Whitish colour. 3-5 inches long.

Habitat-Woods and open places.

\section{Chestnut Boletus}

\section{Boletus castanens}

Cap-Dry, minutely welvety. Cimnamon or reddish-brown. I-3 inches broad.

Flesh-White.

Tubes-White, becoming yellow. Short, and free from the stem. Stem-Clothed and coloured like the cap. 1-2 1/2 inches high.

Habitat-Woods and open places.

\section{Boletus eximius}

Cap-Purplish-brown or chocolate colonr, fading to smoky red or pale chestnut. $3-10$ inches broad.

Fles/ - Greyish or reddish white.

Tubes-Resembling the cap in colour. Mouths minute.

Stem-Stout, covered with a meal-like powder. Colour resembling the cap, grey tinged with purple within. 2-4 inches long. Habitat-Woods.

Scā'-bĕr

Vĕr-sí-pĕl'-lís

Căs-tā-nĕ-ŭs

$\breve{E x-1 m}-1-$ Ĭs 


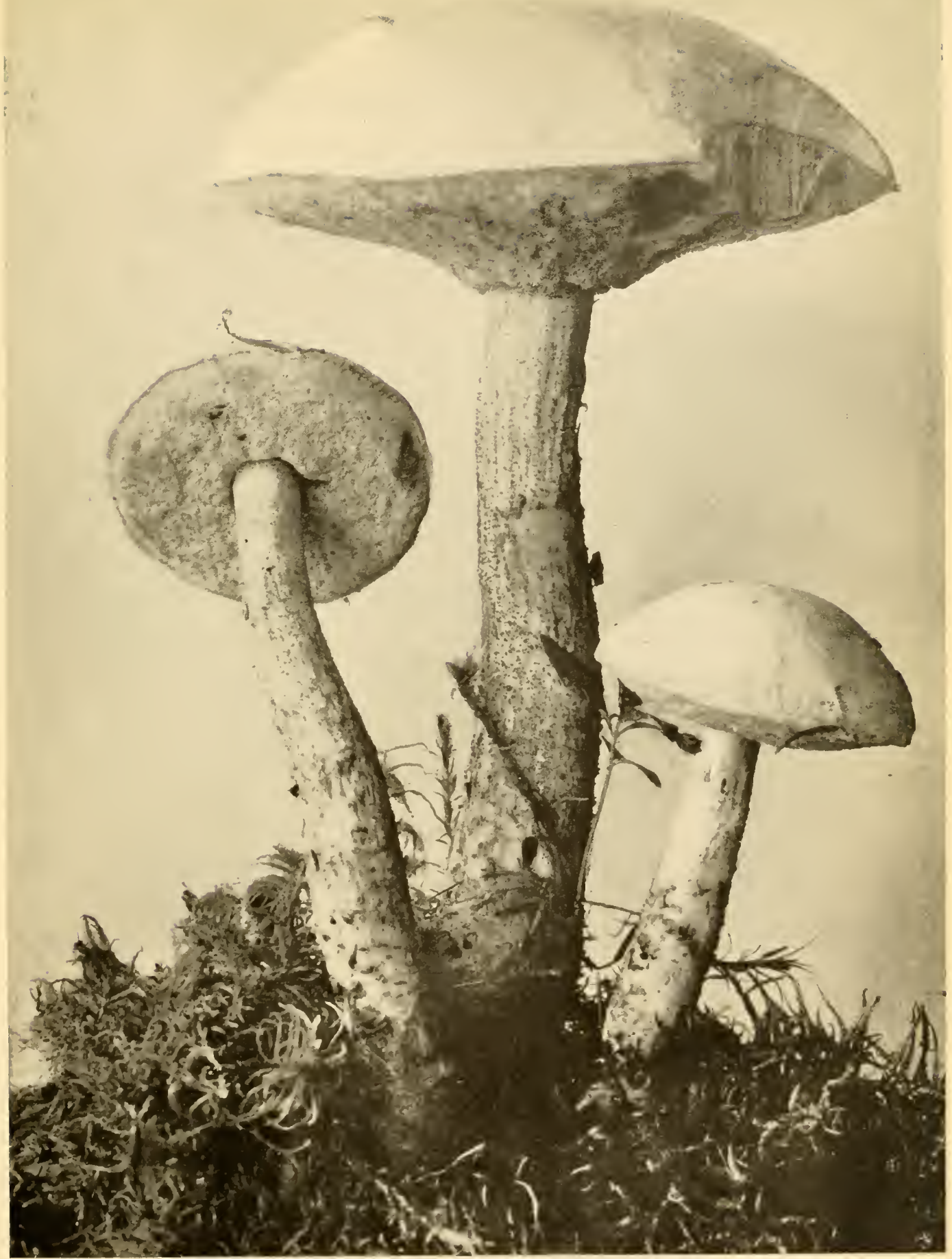

SCABROUS-STEMMED BOLETUS (EDIBLE)

(Bolctus scaber, Fr.; var. niveus, Gill.)

Cap white. Sec p. 108 



\section{Edible Boletus}

Boletus edulis

Cap-Convex or nearly plane; smooth, moist; compact, then soft. Greyish red, brownish red, or tawny brown. 4-6 inches broad.

Flesh-White or yellowish; reddish beneath the skin.

Tubes-Convex, nearly free, long, minute, round. White, then yellow and greenish.

Stem-Short or long, straight or curving, sometimes bulbous, stout, covered with network. Just beneath the stem whitish or brownish. 2-6 inches long.

Habitat-Woods and open places.

\section{Boletus subtomentosus}

Cap-Covered with soft woolly hairs. Somewhat olive green, uniform in colour under the skin, yellow chinks on the surface.

Filcsh-White.

Tubes-Yellow, with large angular mouths.

Stcm-Stout, rugged, with minute dots.

Habitat-Common in woods.

\section{Boletus Americanus}

Cap-Thin, soft, viscid, slightly' woolly on the margin when young: Yellow, becoming dingy with age; sometimes streaked with bright red. $1-3$ inches broad.

Flesh-Pale yellow.

Tubes-Not free from the stem. Large, angular. Pale yellow, becoming tinged with brown.

Stem-Slender. No annulus. Yellow, brownish towards the base, marked with numerous brown or reddish-brown glandular dots: yellow within. $1 \mathrm{x} / 2-2 \mathrm{I} / 2$ inches long.

Habitat-Woods, swamps.

\section{POLYPORACEA}

The fungi with pores permanently united to the surrounding tissue and to each other form a large and important group, the Polyporacea. With but few exceptions they are leathery, corky, membranous, or woody.

Nearly six hundred species have been reported from America.

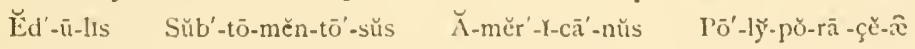




\section{GENUS MERULIUS}

\section{Merulius lacrymans}

The simplest of these Polyporacea is the dry-rot fungus, Merulius lacrymans. The food-seeking portion consists of fine white threads, mycelium, which penetrate the woodwork of buildings, causing it to crumble to dust. The fruiting portion consists of flat, irregular bodies whose under surface bears the spores in shallow pits separated by narrow ridges. Water is excreted from these flat disks, which, from the habit of dropping like tears, has suggested the specific name lacrymans, from the Latin lacrymare, to weep.

\section{GENUS POLYPORUS}

The genus Polyporus and the genus Trametes have the pores closely packed and united to together. In Trametes the uniting substance is the same as the substance of the cap, but in Polyporus the uniting substance is different from the substance of the cap. The genus Polyporus in its widest sense is a large, one, numbering some five hundred species, and containing every texture from fleshy or pulpy to woody.

The fruiting portion is often seen in the form of brackets shelving out from standing or fallen trees. The mycelium penetrates the wood, softening it, and causing it to crumble, so that in the course of time the tree dies. The external evidence that the tree has been attacked is the appearance of the fruiting portion, which often attains a very great size.

\section{Elfvingia (polyporus) megaloma}

Polyporus megaloma is attractive to frequenters of the woods, as its spore surface when fresh is soft an 1 white, and furnishes an attractive surface for stencil drawings.

\section{Elfvingia (polyporus) fomentaria}

The brackets of Elfvingia fomentaria resemble horses' hoofs. They are employed in the manufacture of amadou, or

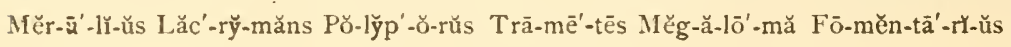




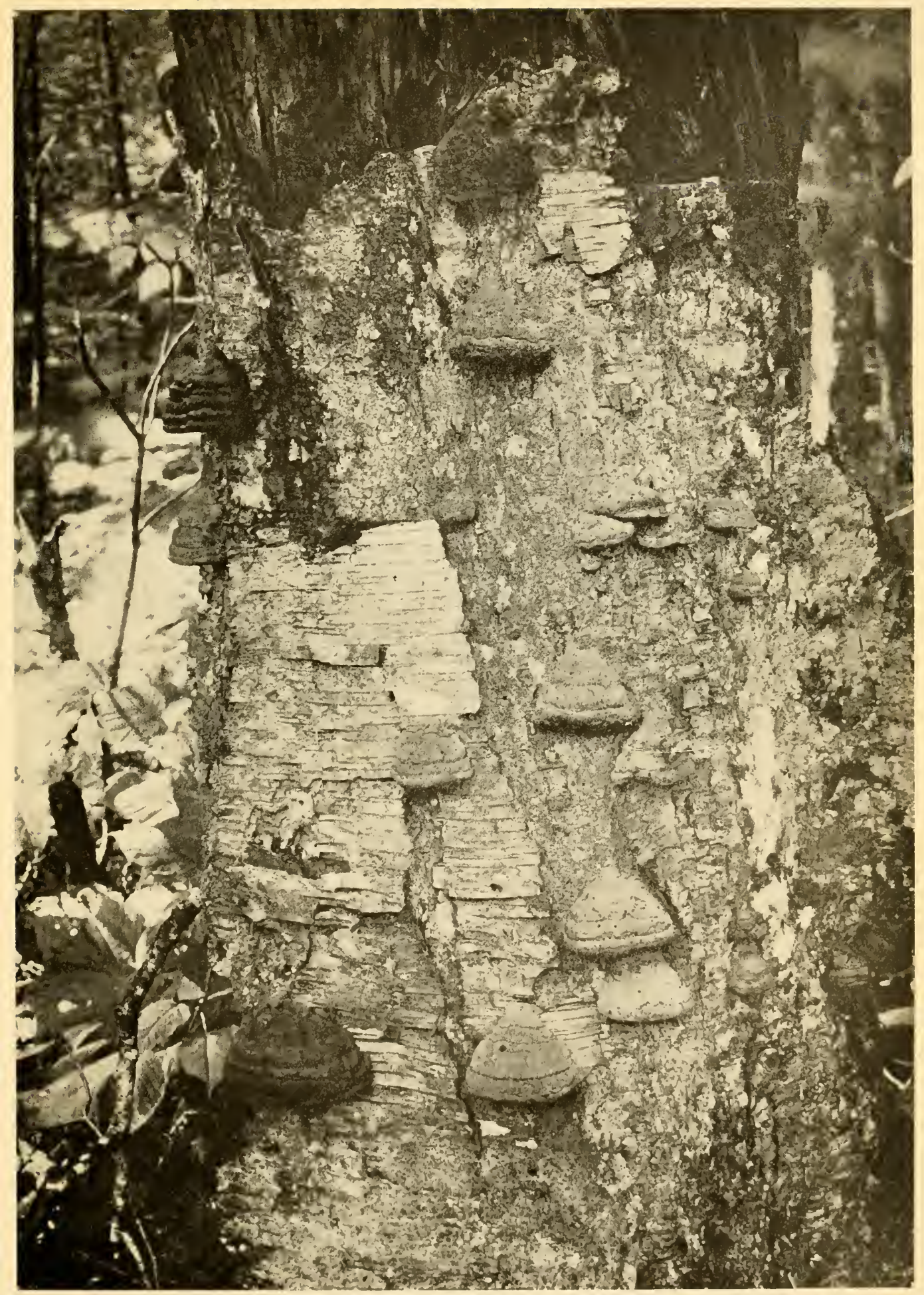

TINDERWOOD POLYPORUS

(Elfingia fomentaria, L.; Fomes fomentarius, Gill.; Polyporus fomentarius, Fr.)

Upper surface grey to brown; tubc-surface concave. See p. :xn 

German tinder, which, in the form of sticks or fusees, commonly known as punk, is used for lighting cigars and pipes in the wind, or for touching off fireworks.

The fusees are made by beating the fungus substance until it is flexible, and then dipping it into saltpetre,

\section{Polyporus conchatus}

Polyporus conchatus is a beautiful species found on the under side of fallen trees, growing in such a manner that from the spore-bearing surface the shells look like rosettes of shimmering golden-brown velvet.

\section{Polyporus velutinus}

Polyporus velutinus is common in the form of stiff ruffles with white or creamy spore surface, and grey or tan-coloured plush-like upper surface.

\section{Polyporus pergamenus}

Polyporus pergamenus has a somewhat bristle-like, tancoloured spore surface, and a velvety drab upper surface, often tinged with green from a green alga which grows upon it.

\section{Polyporus perennis}

Polyporus perennis resembles a slender-stemmed goblet.

\section{Polyporus sulphureus}

Polyporus sulphureus is an edible fleshy form. It grows in clusters, the stemless caps often five or six inches broad and overlapping. The colour of the young cap is yellowish red or pale orange, with the margin wavy, and of a beautiful yellow. It is soft and juicy, and often-when cut-exudes a yellow juice.

The plants may be found on the dead wood of trees during showery weather from May to October. The mature plants become dry and crumbling, and as they dry they lose

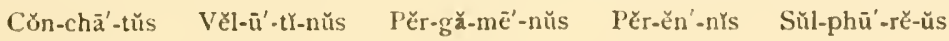


their attractive colours. They exhibit phosphorescence in early stages of decay. The tubes are minute and short and of a bright sulphur colour. Only the young plants should be used for food.

\section{Polyporus squamosus}

Polyporus squamosus is found often on decayed ash trees and sometimes on others. The cap has a thick lateral dark stem and is pale yellow tinged with brown, and covered with dark scales. It is reported to have been found seven feet in circumference, with a weight of forty-two pounds, and that it attained this growth in the short time of four weeks.

\section{Polyporus lucidus}

Polyporus lucidus has a lateral stem which, with all but the margin of the cap, is highly polished, as if varnished, and is in colour a rich mahogany brown.

\section{Polyporus arcularilis (See Plate facing Page 142)}

Cap-Dark brown, minutely scaly, depressed in the centre; margin stiff, edge hairy, no flesh.

Tubes-Dingy cream colour. Openings oblong, almost diamondshape, resembling the meshes of a net, drawn from stem to the margin of the cap, the meshes smaller on the margin, and simply marked out at the top of the stem.

Stem-Dark brown, minutely scaly, mottled, with a ground work of cream colour. Older stems are roughened at the base with whitish hairs. Hollow. Spores-Creamy white.

Habitat-The specimen pictured was found growing on decayed branches of an oak tree in North Carolina.

\section{Polyporus versicolor*}

Polyporus versicolor has a leathery cap, thin and rigid, plane, depressed at the attached portion, velvety, shining with variegated two-coloured zones. The pores are minute, round, with acute and ragged edges. White, then yellowish. It is common on decaying tree trunks and upon telegraph poles.

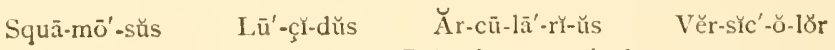

$$
\begin{aligned}
& \text { * Known also as Polystictus versicolor }
\end{aligned}
$$




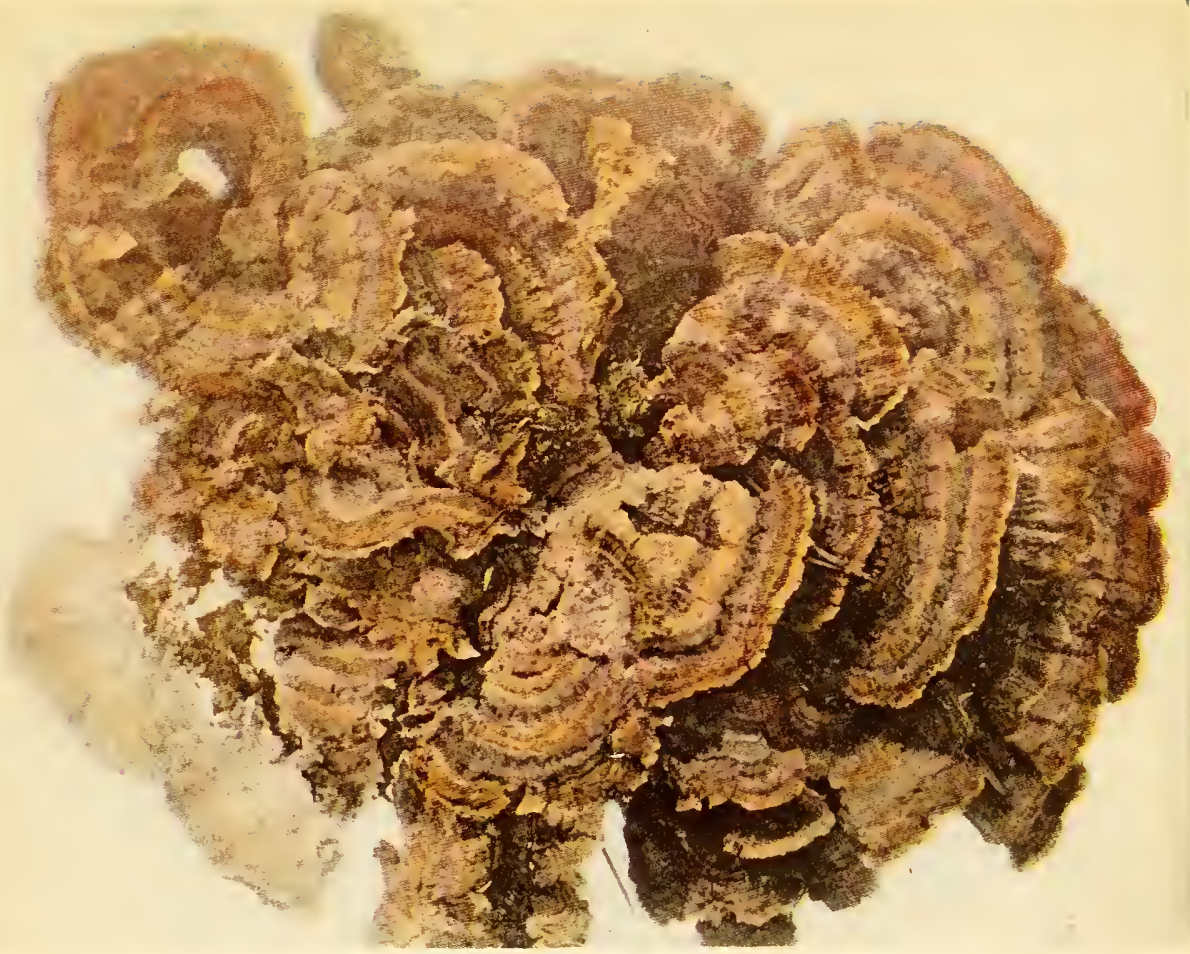

Polyporus versicolor, $\mathrm{Fr}$.

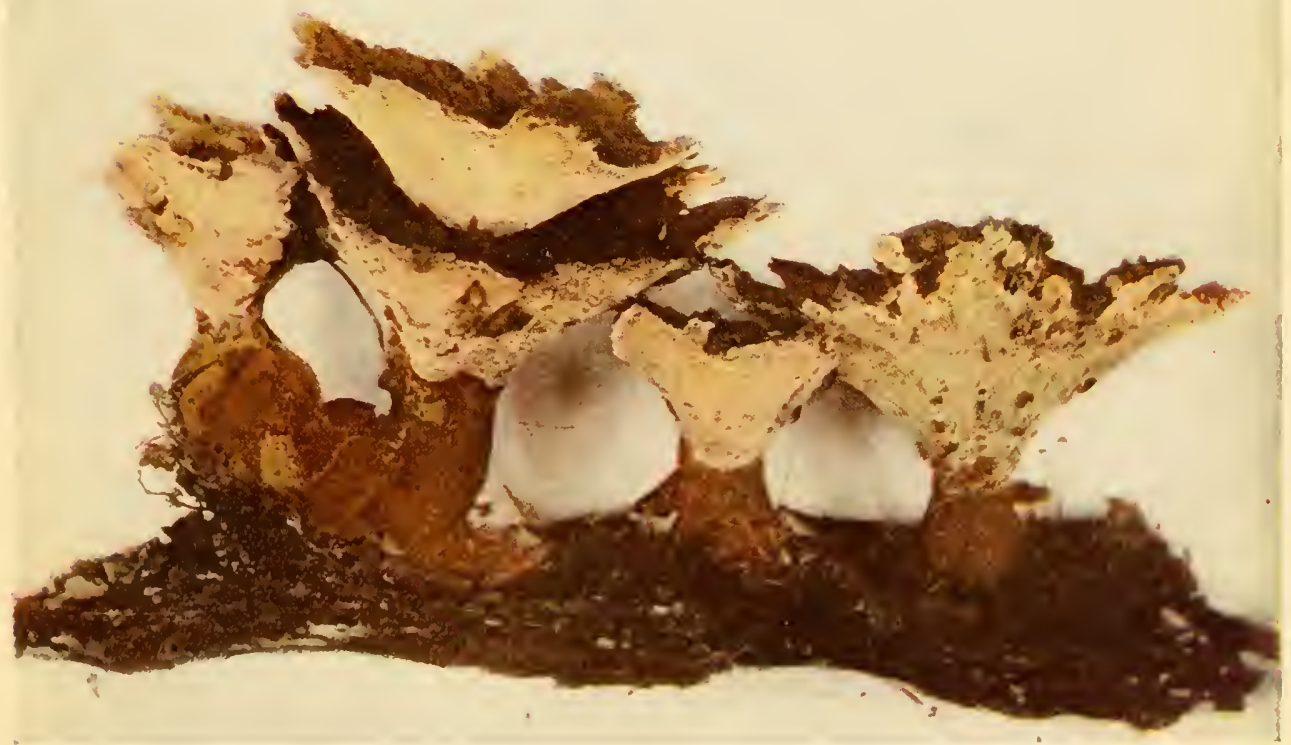

Polyporus circinatus, Fr.

See page 113 




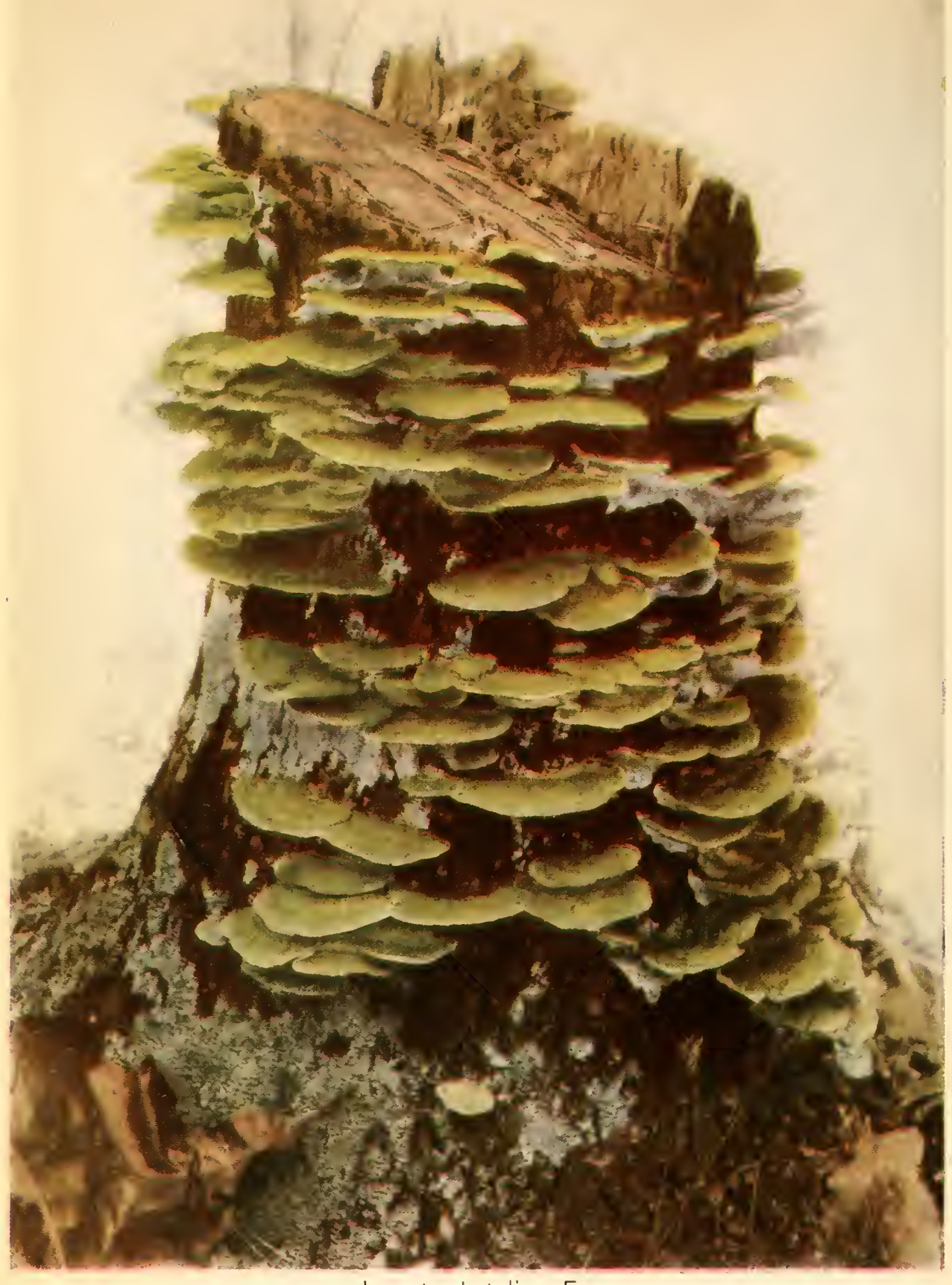

Lenzites betulina, $\mathrm{Fr}$.

See page 113 


\section{Polyporus circinatus (See Plate Facing Page 112)}

Polyporus circinatus quite often has one cap within another. The caps are thick, round, without zones, velvety, and of a rusty-yellow colour. The lower surfaces of the caps, with the stems are woody and corky, but the upper surfaces of the caps are soft and woolly. The stem is swollen and covered with yellow wool. The pores are decurrent, minute, and unbroken, and of a dusky grey colour. This is a handsome species, especially remarkable for its double cap. The stem is an inch long and almost equally thick. The cap is three to four inches wide, and the flesh is uniform in colour.

\section{GENUS TRAMETES}

Trametes pini is brown, and grows on pines and other conebearing trees. Trametes cimnabarina is bright red, and common on birch and cherry. Trametes suaveolens is white, and grows on willows.

\section{GENUS LENZITES}

\section{Lenzites betulina}

The Lenzites betulina has a somewhat corky, leathery cap, firm, and without zones, woolly and pale; the margin of uniform colour; the lamellæ radial, somewhat branching, and coming together again. Sordid white. This fungus, in the form of brackets, is found especially on birch trees, but it is also found on various other kinds. It is a widespread species, and is quite

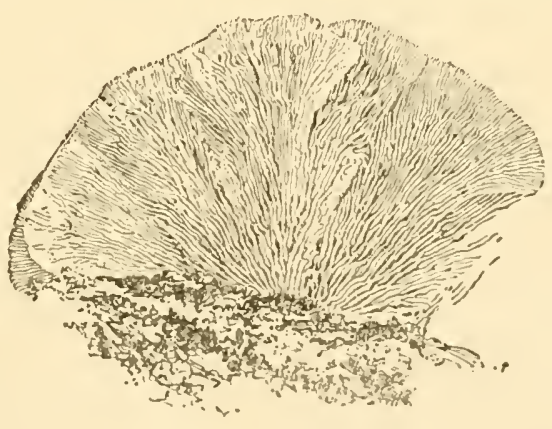

Under surface of L. betulana variable. The lamelle are at first thick, corky, and sordid white; then thinner, with acute edges.

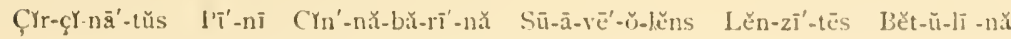


Fungi with Pores-Polyporaceæ

\section{Lenzites sepiria}

Leathery shells, with the upper surface marked with rough zones of various shades of brown: the under surface with brown, radiating, papery gills.

\section{GENUS DAEDALEA}

The genus Dodalea has the spore-bearing surface in the form of winding and labyrinthine lamellæ, so that instead of pores there are irregular branching slits on the under surface. These fungi are normally sessile, woody, and hard.

\section{Dædalea unicolor}

Dadalea unicolor is in form like a full leather ruffle with scalloped edge, so full that the scallops overlap. The branching slits are very minute, and the upper side is in zones of tan colour, with a plush-like surface. The zones are often tinged with blue or green from algæ which grow upon them.

\section{Dædalea confragosa}

Dedalea confragosa has a rough grey upper surface, and grows from the centre in the form of depressed sessile caps. The texture is firm and leathery.

\section{Dredalea quercina}

Dadalea quercina is a woody or corky species, rugged, and without zones on the surface. At first it is porous; then, by the breaking down of the walls of the pores, slits are formed, with blunt partitions. It is common on oak trees.

$$
\text { Sē-pī'-rY-ă Dre-dā'-lē-ă Cơn'-fră-gōó-să Quěr-çī'-nă }
$$




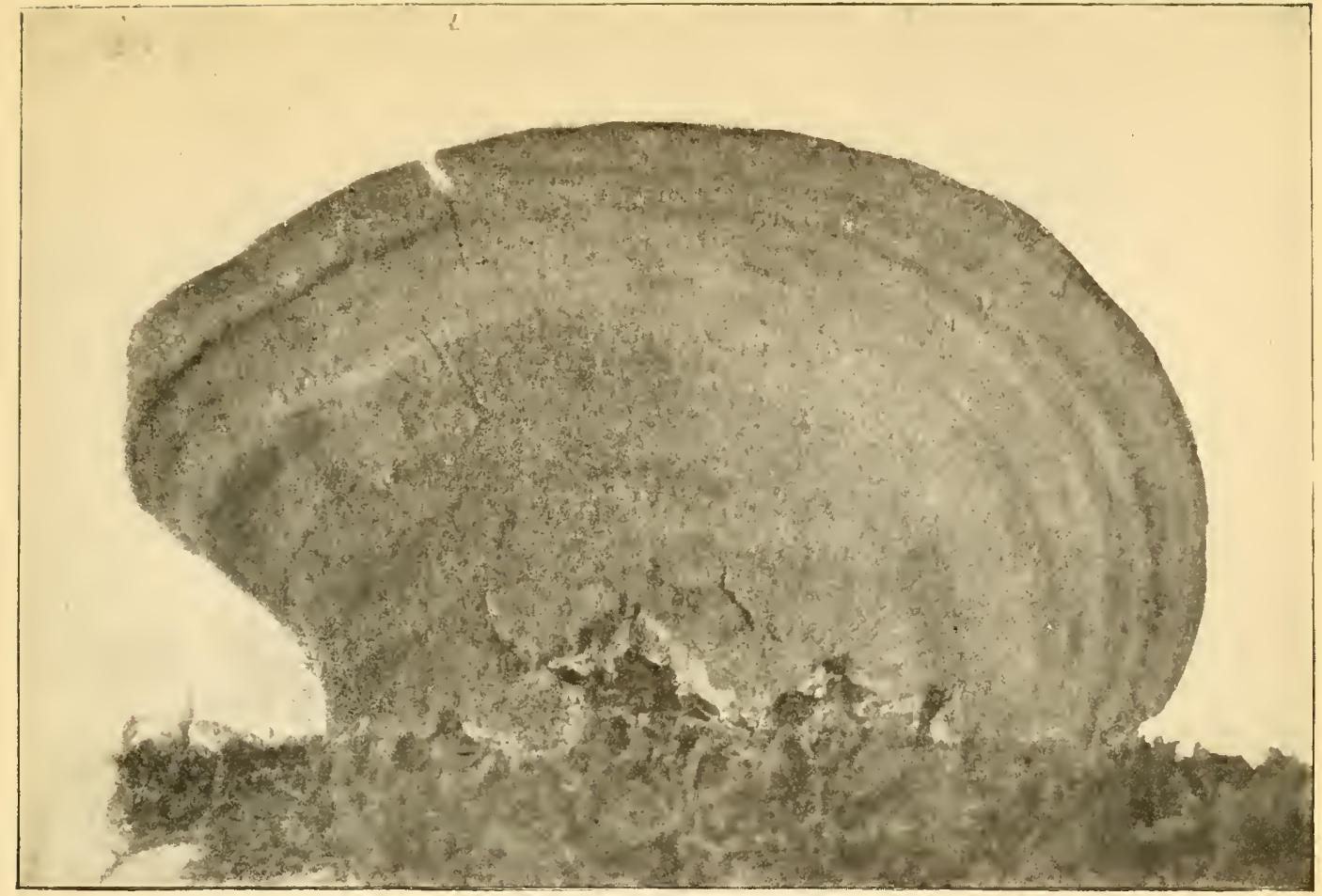

Dadalea quercina, (L.) Pers.

Upper side. Reduced

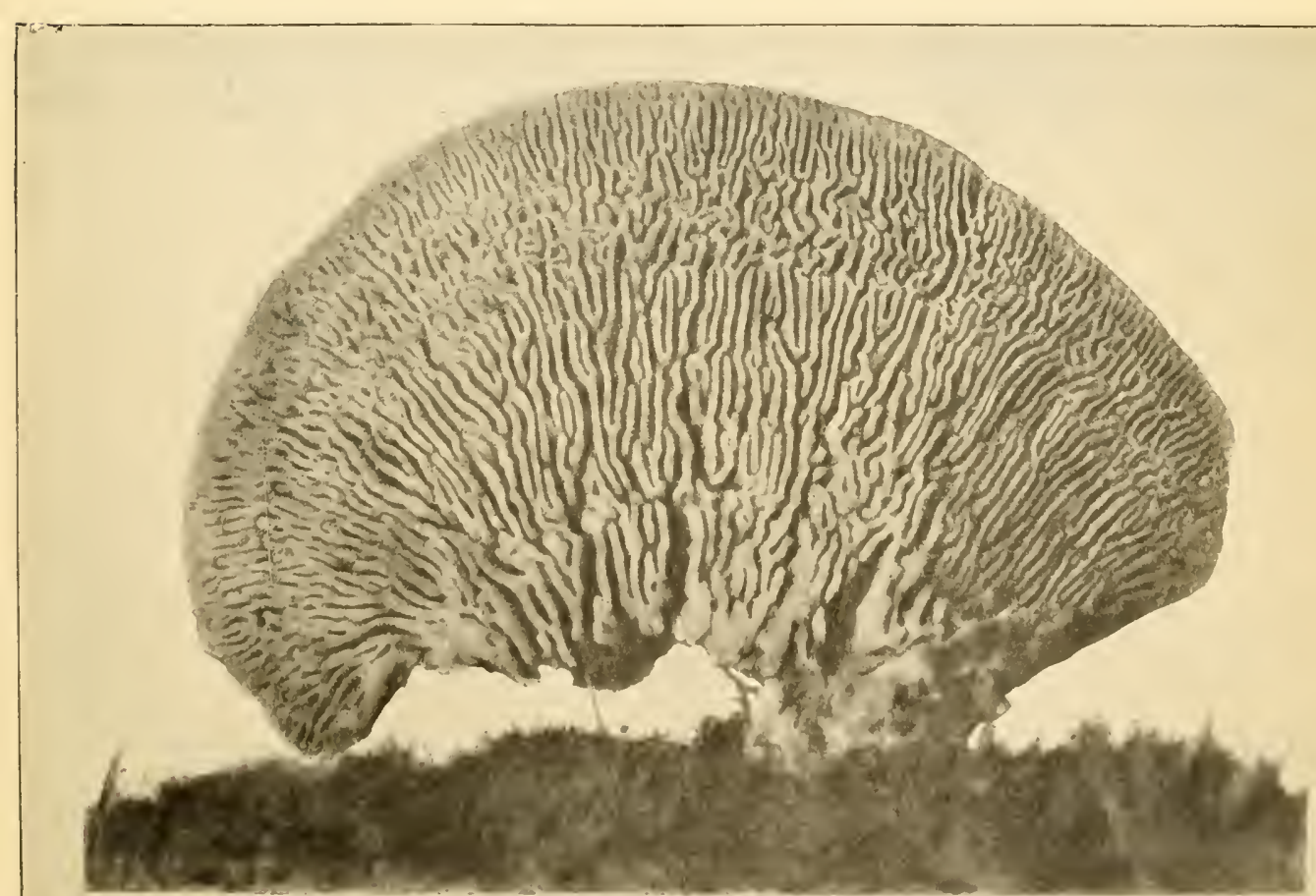

Dadalea quercina, (L.) Pers.

Lower side. Reduced 



\section{GENUS FAVOLUS}

The genus Favolus has but few species; one is very common on beech and hickory trees. Favolus areolarius has a lateral stem. The cap is depressed, and has a smooth, creamy-white upper surface, with long hexagonal pores running down the short stem.

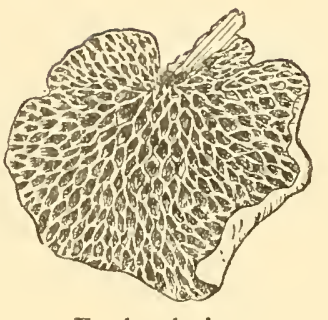

Fắ-vŏ-lŭs

F. alveolarius 


\title{
CHAPTER IX: GELATINOUS AND CTHER FUNGI
}

\author{
Jew's Ear, or Judas's Ear (Edible)
}

Hirneola auricula-Juda

THE Jew's ear is a gelatinous fungus which is so lobed and folded as to resemble a human ear. It is this resemblance to an ear which has suggested the names, Jew's ear and Judas's ear. Its habit of growing on elder has given rise to the belief that Judas Iscariot hanged himself on this tree. This fungus is prized by the Chinese as an article of food, and is imported by them from the South Sea Islands.

Its manner of bearing the spores on basidia places it in Class 1II, Basidiomycetes, which contains fungi with gills, teeth, and pores.

\section{Tremellodon}

Tremellodon is a clear fungus, which in colour resembles a piece of water-soaked snow, but in form resembles a Hydnum, as it has teeth-like projections on the under surface.

\section{Guepinia}

Guepina is a bright yellow fungus, about an inch high, in form like little spatules or goblets. It is common in cracks of logs and stumps.

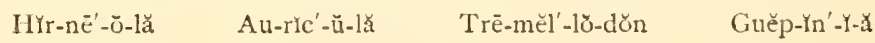





\section{CHAPTER X: OFFENSIVE FUNGI-ORDER PHALLALES}

THE Phallales are ill terrestrial fungi; that is, they are found growing on the ground, and not on logs and trees. They are interesting, but too offensive to attract any but the most courageous students.

They are more common in the South than in the North, where they make themselves too conspicuous by their intolerable odour.

They are structurally different from the other pouch-fungi, the puffballs, in that they do not retain their spores in the skin (peridium) until they are fully mature, but send them into the light, exposed on a quickly deliquescing jelly-like mass, the gleba.

The order may conveniently be divided into two families:

FAMILY I. ClathraCEA $\left\{\begin{array}{l}\text { Receptacle latticed, sessile, or stalked. } \\ \text { Spore mass borne on the inner sur- } \\ \text { face of the receptacle. }\end{array}\right.$

Family II. Phallace $A \begin{aligned} & \text { Receptacle tubular or cylindric, with a } \\ & \text { cap. } \\ & \text { Spore mass on the surface of the cap. }\end{aligned}$

\section{GENUS PHALLUS}

\section{Stinkhorns}

The genus Phallus may be readily distinguished by the cylindrical shape of the spore receptacles and the intolerable odour. No one with his sense of smell developed would think of eating the members of this group. The botanist and the artist, however, have braved this lion on his own territory, and have found much that is beautiful and interesting; the artist having the advantage in his task of portraying the handsome specimen,

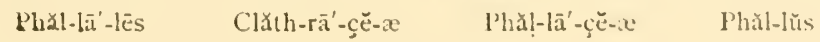




\section{Offensive Fungi}

in that he can inclose it in a sealed glass case and work in comfort. The experience of the botanist must be realised to be appreciated.

An overpowering fetid odour suddenly evident upon the premises has many times filled with consternation the guests at summer resorts, causing among them much speculation, with suggestions of bad sewerage, and carelessness on the part of their host, together with other comments equally disastrous to the reputation of the place.

The distracted householder searches in vain for a solution of the difficulty, and the odour disappears as mysteriously as it came. If he is one of the initiated, however, he will search until he finds the haunt of the offender, and will destroy all chance of a repetition of the nuisance-for one summer, at least.

The mischief-maker is a handsome specimen, as its plate shows. The white stem, bearing at its summit a mass of gelatinous green substance capped with a yellow-white ring, and emitting its intolerable odour, has surely come into existence for a purpose-a purpose soon suggested-as hundreds of flies wing their way hither to sip the semi-fluid mass.

The botanist tells us that the spores of this plant are mixed in the green fluid, and that they are carried away on the feet and in the bodies of the flies to other places, where new colonies may be started.

The plant has undoubtedly emerged from the ground for the sole purpose of disseminating its spores, and all its parts have been developed to accomplish this function in the most effectual manner.

The banquet for the flies is prepared underground, and the table, with its viands all ready, is pushed into the light, while the invitation to the guests is wafted swiftly on the breeze.

One is curious to learn the mechanism by which so much is accomplished in apparently so short a time, and finds in this instance, as in all others whe:e great things are accomplished with ease, that many forces have been slowly at work to insure everything being in readiness for the success of a final flourish. A search underground shows the mycelial threads to have permeated the soil for many feet in every direction in search of building material, and a glance at a vertical section of one of the pink eggs which has pushed its way out of the soil will show 


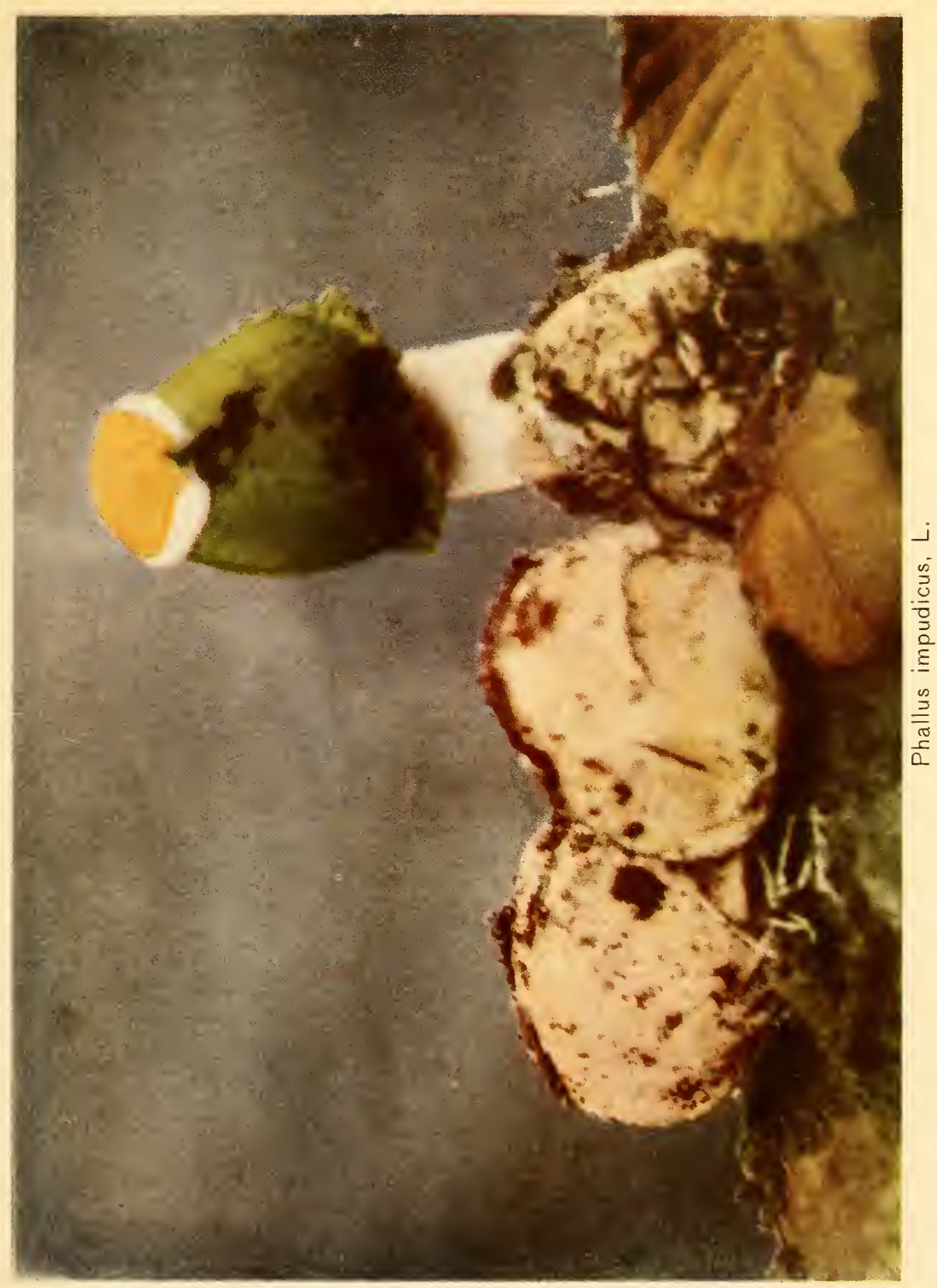



in outline the plan of what is to be. The pink "eggshell," or peridium, is lined with a jelly-like substance, which has un-

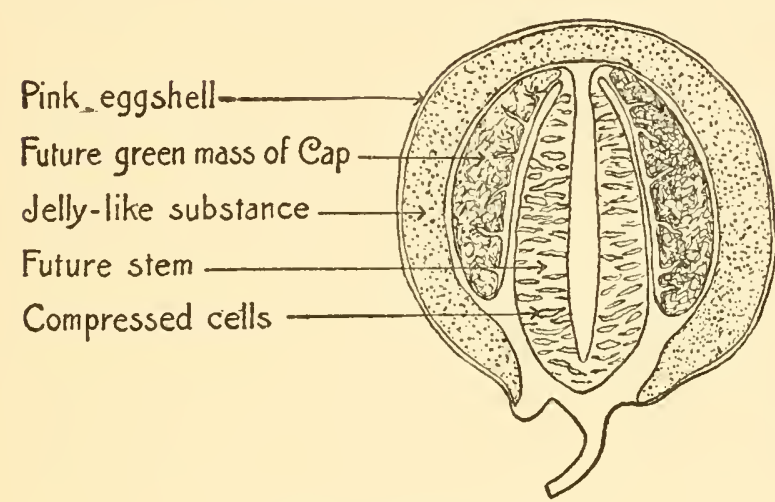

Section of young phallus doubtedly served as a safe packing to what is within, a protection a g a i n s t blows and insect ravages. Within this coat, in section, appears as two $\mathrm{d}$ a rk-coloured saddle-bags that which later is to form the green mass on the cap of the fully developed spore table. Between these dark masses lies in section the future stem; it is hollow, and bears on its rim the spore-bearing cap. The walls of this cap consist of flattened cells, which by extraordinary growth and expansion are to force the stem through the eggshell and carry the banquet of spores several inches into the light, leaving the torn wrapper as a volva at its base, a natural "Jack-in-the-box."

\section{Phallus impudicus}

Cap or Pileus-Outer surface bearing the spores in a jelly-like mass, gleba. Conic-campanulate. Outer surface sculptured with reticulated ridges after the green spore mass has disappeared.

Stem-Hollow, tapering at each end; upper end joined with the cap by a recurved border.

Veil-Wanting.

Volva-Pinkish.

Habitat-Low ground.

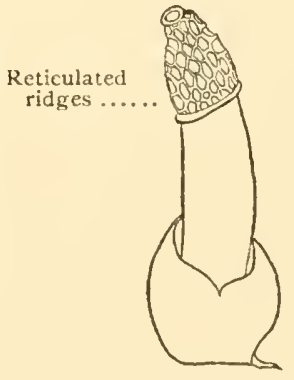

P. impudicus

İn-püd'-Y-cŭs 


\section{GENUS DICTYOPHORA}

The genus Dictyophora differs from the genus Phallus in having a veil suspended from the apex of the stem, underneath the pileus or cap.

\section{Dictyophora Ravenelii}

Stem-Tapering at both ends.

Veil-Short, not reaching below the cap.

\section{Dictyophora duplicata}

Veil-Voluminous, hanging for several inches below the cap.

It is thought that this delicate white network, which hangs like a lace skirt below the cap, renders the fungus additionally conspicuous after dark, thus attracting the night moths and other night-flying insects.

\section{Mutinus Caninus (See Plate Facing Page 136)}

Cap or Pileus-Flesh coloured. The spore-bearing mass, oblong, ovoid, or conical, occupying one-third to one-sixth the total length of the stipe.

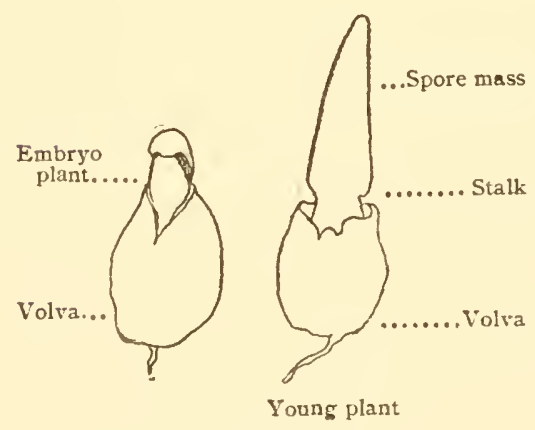

M. caninus

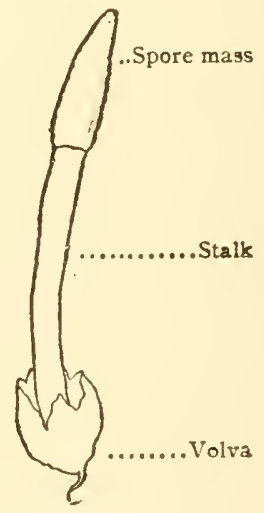

II. bambusinus

Stem or Stipe-Hollow, cylindrical, fusiform.

Habitat-About buildings, in gardens and thickets.

$$
\begin{aligned}
& \text { Dic-ty̆-ð̌ph'-ð̌-ră } \\
& \text { Ră'-věn-ěl'-ii }
\end{aligned}
$$

Dū-plī-cā'-tă

$M u ̈-t^{-1} \cdot$ nŭs
Cā-nī'-nŭs Băm·bū-sī'-nŭs 


\section{FAMILY CLATHRACEAE}

The members of the family Clathracea have a volva similar to the volva of the Phallacex. The volva ruptures, and the receptacle issues in a similar manner. The members of this family have the spore receptacle latticed or branched instead of tubular or cylindrical, and bear the spores on the inner surface of the receptacle rather than on the outer surface.

\section{Latticed Clathrus}

\section{Clathrus cancellatus}

Receptacle not stalked. The bars of the lattice-work are oblique and transversely wrinkled. The outer surface may be cinnabar red or white or yellowish. The inner surface of the bars is red.

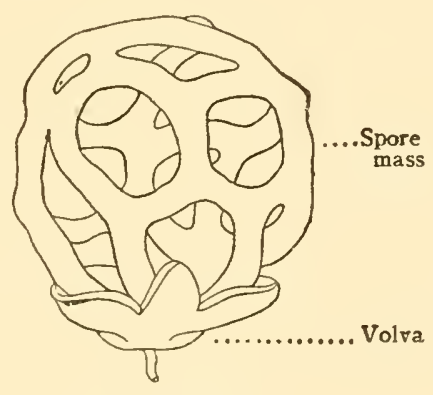

C. cancellatus

\section{Clathrus columnatus}

Receptacle not stalked, consisting of from 2-5 vertical columns, separate below, but jointed at the apex. Columns cinnabar red, enclosing the spore mass. Odour very fetid.

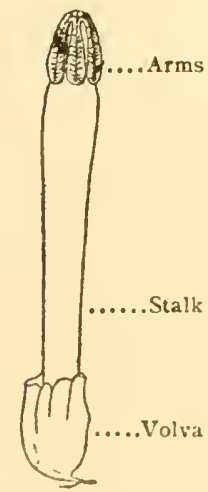

A. borealis

\section{Anthurus borealis}

Receptacle stalked, hollow, divided above into arms, which do not join at their apices, and which bear the spore masses on their inner surfaces, enclosing the spore mass when young, but later diverging.

Stem of receptacle white; arms narrow lance-shaped, with pale flesh-coloured backs, traversed their entire length by a shallow furrow. Clăth-rä'-ç̧ě-xe
Clăth'-rŭs
Cản-çěl-lā'-tŭs Cŏl-ŭm-nä'-tǔs
Ăn-thü'-rŭs

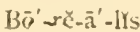


Offensive Fungi

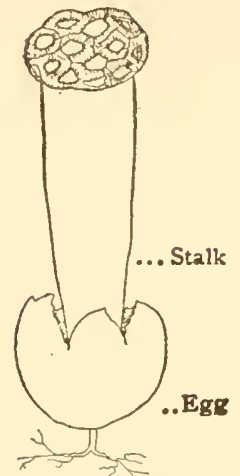

\section{Simblum rubescens}

Receptacle stalked and globular, bars of the lattice forming meshes of about equal diameter either way. Red or flesh coloured, and transversely wrinkled.

SYm'-blŭm

Rŭ-běs'-çěns

S. rubescens 


\section{CHAPTER XI: PUFFBALLS}

\section{ORDER LYCOPERDALES}

THE pouch fungi include all fungi which have their spores or seeds in closed chambers until maturity - that is, until they are fuily ripe and ready to be scattered by winds or animals. Collectively, the closed chambers are called the gleba, and this gleba is surrounded by a definite rind (peridium), which, in different puffballs, has various and characteristic ways of opening to permit the spores to escape.

The different ways in which the rinds (peridia) open are explained under the separate examples of the pouch fungipuffballs, earth-stars, stinkhorns, birds' nests, and calostomas.

The Lycoperdales, known in different parts of the country as smokeballs, devil's snuffboxes, puffballs, etc., have their spores enclosed until maturity in closed chambers, surrounded by a continuous skin or peridium. They spend most of their lifetime underground, getting their food from decaying vegetable matter, and are for this reason called subterranean saprophytes. When they are about ready to scatter their spores, they emerge from the ground, and are then to be seen in pastures, and on fallen logs in woods and along roadsides. Every country child has pinched them to see the "smoke" rise, little knowing that he was doing for the puffball just that for which it had come into existencescattering its spores far and wide to grow into new plants.

The plants of the puffballs, the mycelial threads, form an extensive network of white threads in the decaying vegetable matter in which they grow ; then little balls appear on the white threads, as in the Agaricales, with the difference that they increase in size without forming gills and stem. The balls have a fleshy interior, cheesy and white at first, but afterwards yellowish or pinkish, gradually darkening until the whole or a part

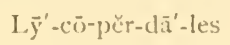


of the fleshy interior becomes filled with dust-like spores, when the rind of the ball breaks to let the spores escape.

Sometimes the wall breaks off in scales; sometimes it is punctured at the summit with one hole, sometimes with several, and sometimes it splits and turns back to form a star on the ground. Sometimes the balls contain elastic threads (capillitium), which help to push out the spores, and sometimes they do not. Sometimes there are threads massed at the base without spores in them, so that they form a sterile base or sterile subgleba, and sometimes the threads are massed to form a central column (columella) in the interior of the ball. These characters, with others, form the basis on which the puffballs are separated into the genera Lycoperdon, Geaster, Calvatia, Bovistella, Bovista, and Calostoma.

\section{GENUS LYCOPERDON}

The Lycoperdons, or true puffballs, produce within the ball vast numbers of dust-like spores mingled with elastic threads. When the ball is compressed, the rind or peridium bursts at the

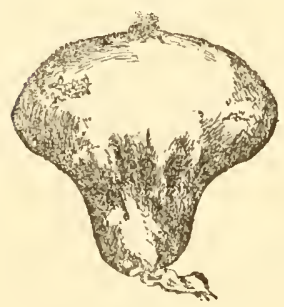

Lycoperdon summit to form a single mouth, and the elastic threads cause the spores to fly out in puffs like smoke.

The spore-bearing part of the plant is globe-shaped, obovoid, or top-shaped, and at the base of the gleba no spores are produced; the cells here are coarse and empty.

The rind or peridium of the ball consists of two parts, the outer bark or outer peridium being adorned with spines or scales or warts or granules. Sometimes the exterior coat may be peeled off, sometimes it dries and falls away in fragments. The inner coat is thin and papery, and opens on the top with one opening. At first the ball is fleshy within, the microscope showing the flesh to consist of a great number of simple or branched threads and enlarged cells. The enlarged cells bear usually four

$$
\text { Lȳ'-cō-pěrr'-dŏn }
$$

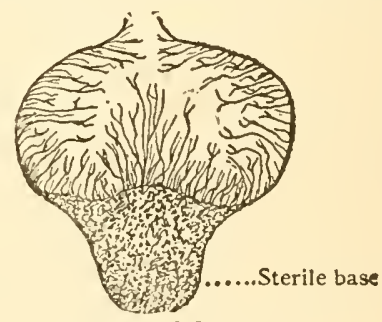

Section of Lycoperdon (diagrammatic) 


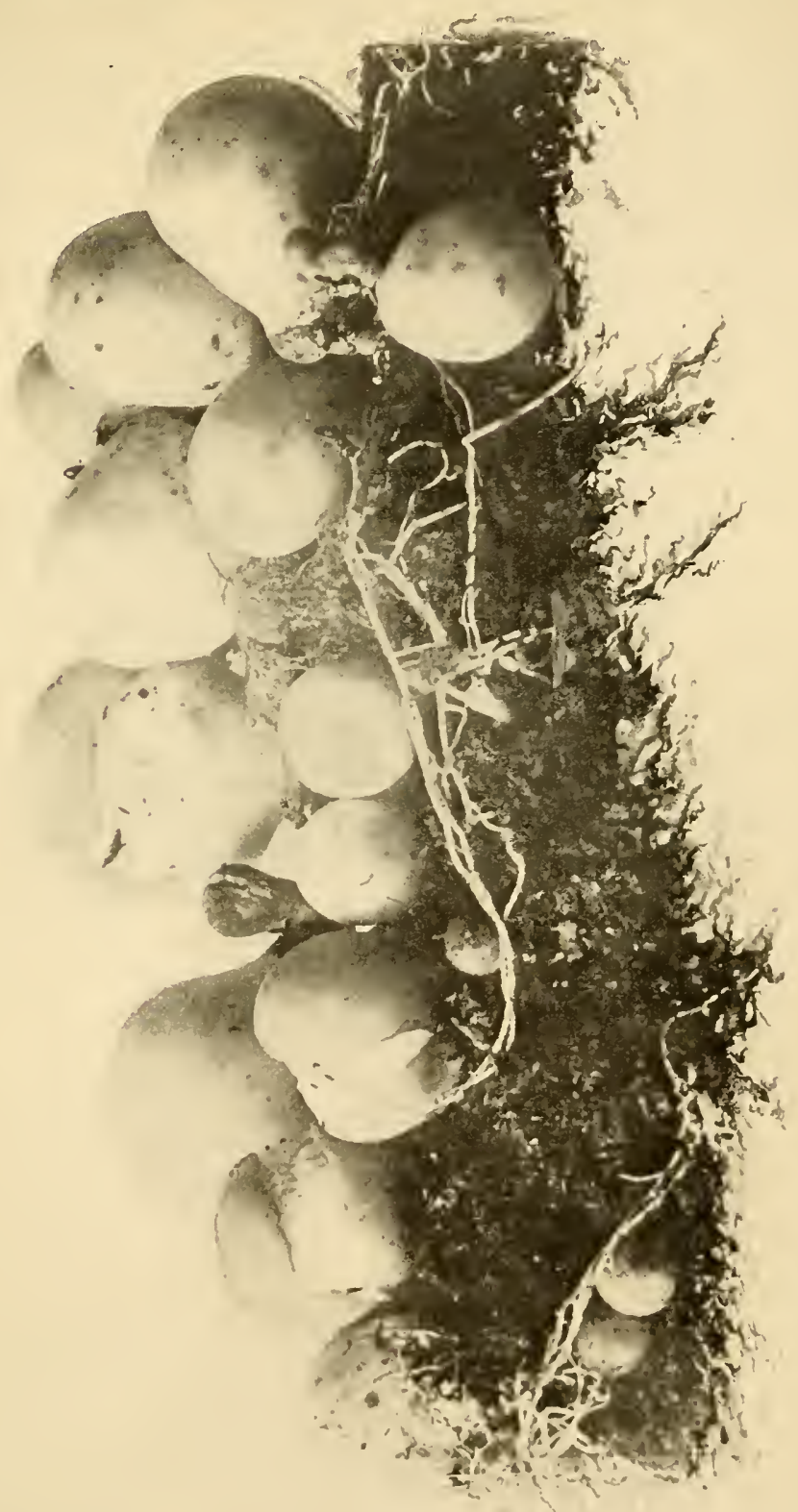

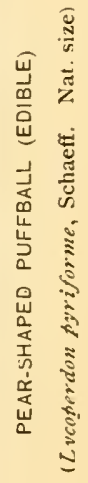



spicules, on the tips of which are the spores. When the plant is fully developed, the fleshy part becomes so filled with moisture that water may be squeezed out as from a sponge. As the flesh becomes moist, the colour changes from white, through yellow, to olive. After the change in colour, the wet mass becomes dry and powdery, a mass of globose spores and elastic threads or capillitium.

The Lycoperdons are of small size, usually found in fields and woods. A section made by cutting a ball from top to base will show that the threads form a more or less well developed sterile base or subgleba underneath the fertile gleba, or mass of threads containing spores. Sometimes the sterile threads from the base rise upward in the centre of the fertile mass and form a little column, the columella. Usually the threads which bear the spores are in two sets; one set extending inward from the walls of the rind, and another set extending outward from the central columella.

\section{Pear-shaped Puffball (Edible)}

\section{Lycoperdon pyriforme}

Peridium or Pouch-Pear-shaped. Dingy white or brownish, with mycelium of long, white, branching fibres. Diameter $3 / 4-11 / 4$ inches. Height $1-2$ inches.

Bark or Outer Coat-Thin; of minute, often persistent, scales or granules, or short, stout spinules. Whitish grey or brownish. Inner Coat-Smooth, papery, whitish grey or brownish, opening by apical mouth.

Subgleba-Small, white, quite compact, the cells minute. Columella-Present.

Spores-Globose, even, greenish yellow to brownish olive.

Threads-Branched, long, forming a dense tuft in the centre. Time-July to October.

Habitat-On old timber or on the ground, in groups sometimes several feet across in extent. The commonest of puffballs, and found throughout the world.

\section{Pinkish Puffball (Edible)}

\section{Lj'coperdon subincarmatum (See Plate Facing Page 1;4)}

Peridium or Pouch-Globe-shaped, sessile, without a stem-like base. Rarrely over one inch in diameter.

$$
l^{\prime} \bar{y}^{\prime} \text {-rì-für'-mě }
$$

Sŭb-In'-căr-nā - tŭm 
Puff balls

Bark or Outer Coat-Pinkish brown, with minute short, stout spinules, which fall away at maturity.

Inner Coat-Ash coloured. Deeply pitted by the falling off of the spinules of the outer coat, the pits not surrounded with dotted lines.

Columella-Present.

Subgleba-Small but distinct.

Spores and Capillitium-Spores round, minutely warted. Greenish yellow, then brownish olive. Threads long, simple, and transparent.

Time-August to October.

Habitat-Old trunks in woods.

\section{GENUS CALVATIA}

The Calvatias are puffballs of large size, all with thick cordlike mycelium rooting from the base. They all eject their spores

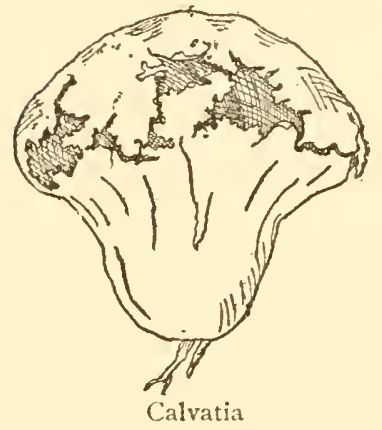
through irregular openings in the upper part of the peridium, and they all have a d ense network of branching threads (capillitium) traversing the tissues of thesporebearing por$\mathrm{t}$ i o $\mathrm{n}$, the

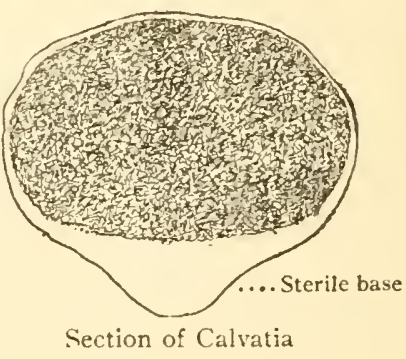

gleba. These threads are elastic, and project the spores from the rind or case as they twist and turn. The sterile portion, the subgleba, is definitely limited and concave above.

\section{Brain-shaped Calvatia (Edible)}

\section{Calvatia craniformis}

Peridium or Pouch-Very large, obovoid or top-shaped, depressed above.

Bark or Outer Coat-Smooth, very thin and fragile, easily peeling off. Pallid or greyish, often with a reddish tinge ; often

Căl-vā'-shY-ă

C'rā-nY-fŏr'-mIs 


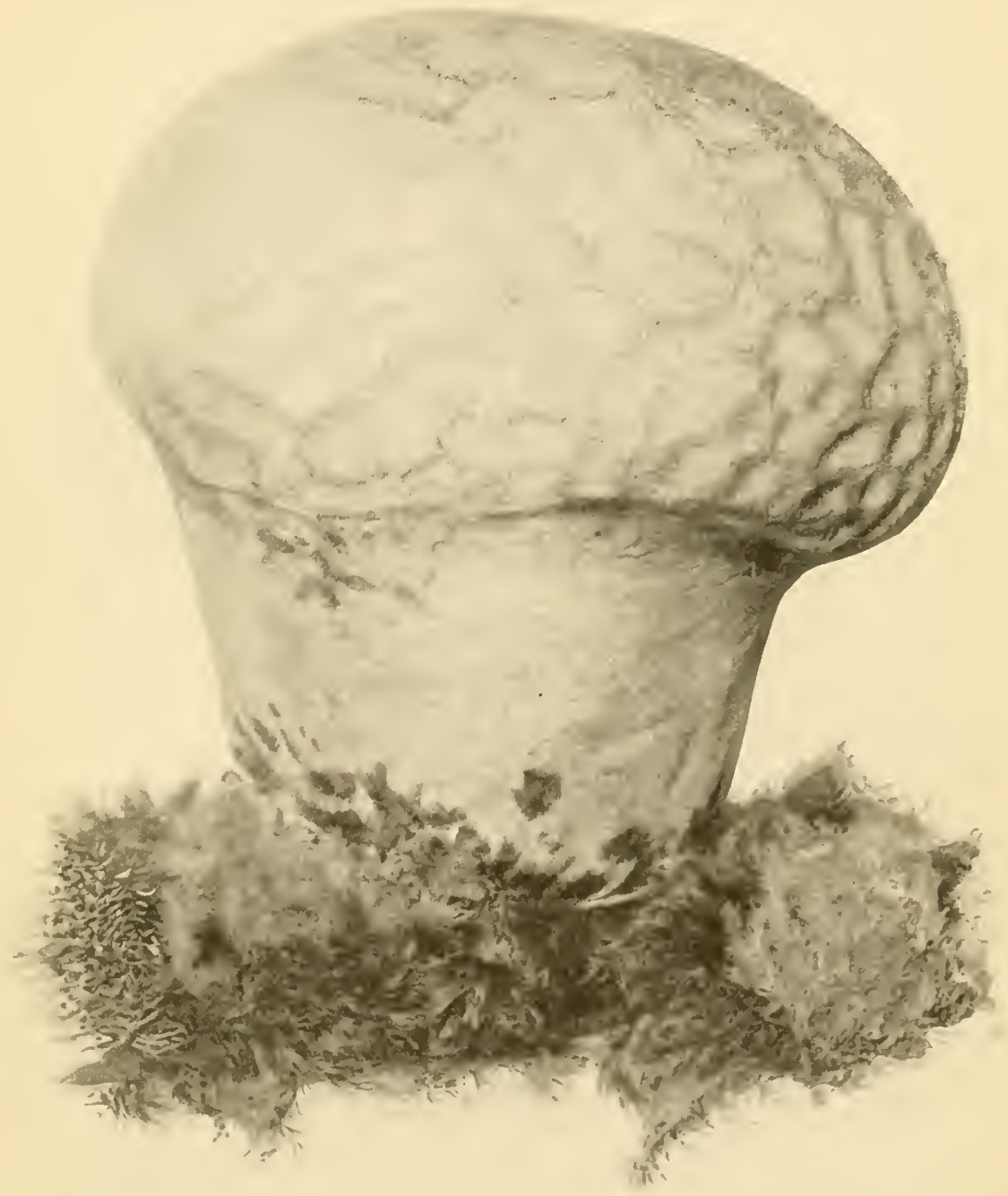

BRAIN PUFFBALL (EDIBLE)

(Caliatia cranifornis, Schw.) 

wrinkling to resemble somewhat the surface of the brain, whence its name craniformis.

Inner Coat-Thin, ochreous to bright brown, velvety, extremely fragile. The upper part breaks into fragments.

Subgleba-Occupies half the peridium; cup-shaped above, persistent.

Spores-Greenish yellow, then olivaceous. Globose, even, with minute pedicel.

Threads-Long.

Habitat-On ground in woods.

\section{Giant Puffball (Edible)}

\section{Calvatia maxima}

Peridium or Pouch-Very large, 8-15 inches in diameter, or larger. Globose, depressed globose, or obovoid, with a thick cordlike root.

Bark or Outer Coat-Flocculous or nearly smooth, thin, and fragile. White or greyish, becoming yellowish or brown; usually remaining closely adherent to the inner coat.

Inner Coat-Thin and fragile after maturity, breaking up into fragments.

Subgleba-Shallow or none.

Spores and Threads-Greenish yellow, then brownish olive. Spores globose, threads long and branched.

Time-August to September.

Habitat-Grassy places.

Calvatia maxima has been known as Lycoperdon giganteum, and also as Lycoperdon maxima. It has been transferred from the genus Lycoperdon to the genus Calvatia because it ruptures the peridium irregularly to discharge its spores, instead of forming a small hole at the apex, as other Lycoperdons do.

It is asserted on good authority that the giant puffball has been found with a diameter of three feet and a weight of fortyseven pounds. The giant puffball is considered by many as a choice article of food when the flesh is white. It is said that if the flesh of a growing puffball is cut or injured the wounds will fill up with new tissue. It will be interesting for some one to try this experiment.

In the days before matches came into use, the dry, spongy threads were used as tinder to catch the sparks which flew from the flint-stone when it was struck for fire, and the spore-dust was used to stanch the flow of blood. 


\section{Cup-shaped Puffball (Edible)}

\section{Calvatia cyathiformis}

Peridium-Large, top-shaped.

Bark or Outer Coat-Thin, adherent, smooth, and continuous, easily peeling off.

Inner Coat-Pale to dark purple, loosely woven, fragile at maturity, breaking up into fragments from above downward.

Subgleba-Short and thick, with cord-like root, persistent, cupshaped, occupying $1 / 3-1 / 2$ the peridium.

Spores and Threads-Violet to dark purple. Spores globose and warted, threads long.

Time-August to October.

Habitat-On the ground in meadows and pastures.

The old name was Lycoperdon cyathiforme. Cyathiforme, meaning cup-shaped, is suggested by the cup-like base which remains after the dispersion of the spores and threads (capillitium).

\section{GENUS BOVISTA}

In the genus Bovista the rind or peridium opens by an apical mouth, as do the species of Lycoperdon, but the species of

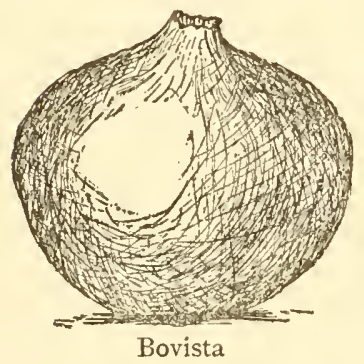

Bovista have no sterile base. They are puffballs of small size, growing in fields and woods. The outer coat is thin and fragile, and scales off

at maturity. The inner coat is thin, becoming papery, and then opens by an apical mouth.

Bovista plumbea is esteemed a delicacy. It is shaped like a flattened globe, with a smooth, white inner coat, and a leadcoloured outer coat opening by an apical mouth.

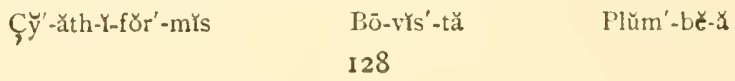





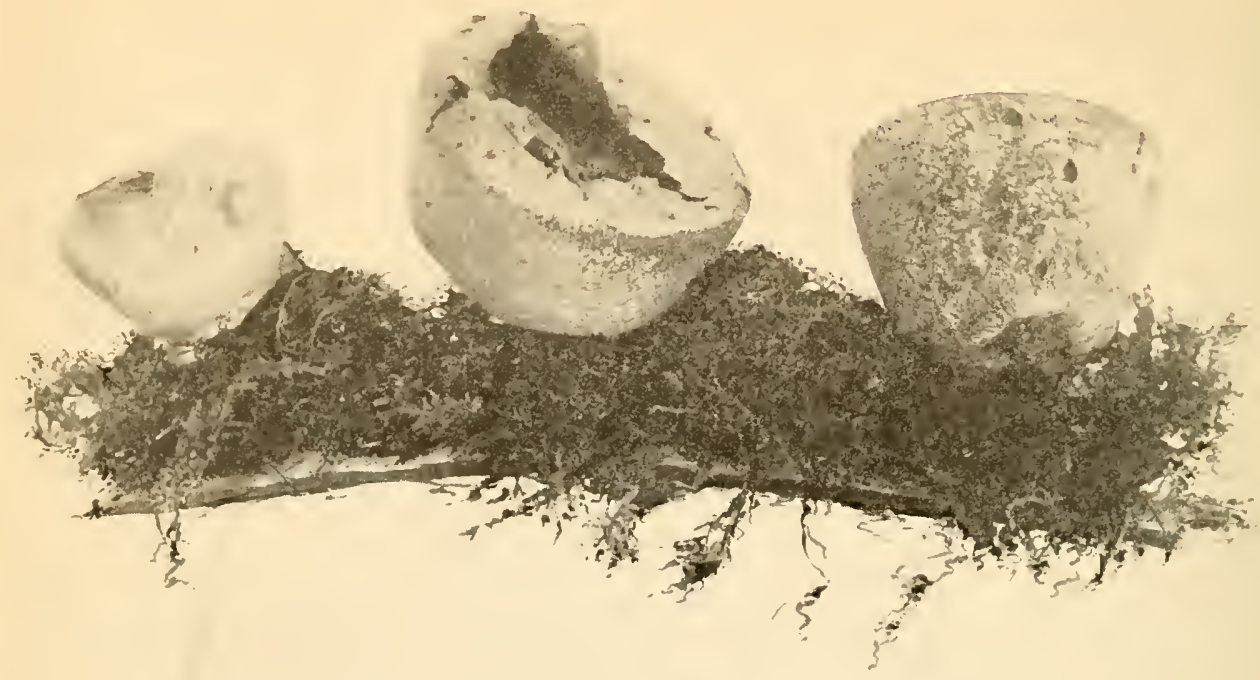

Boristella O'iensis, Ellis and Morgan

(Edible.) Reduced

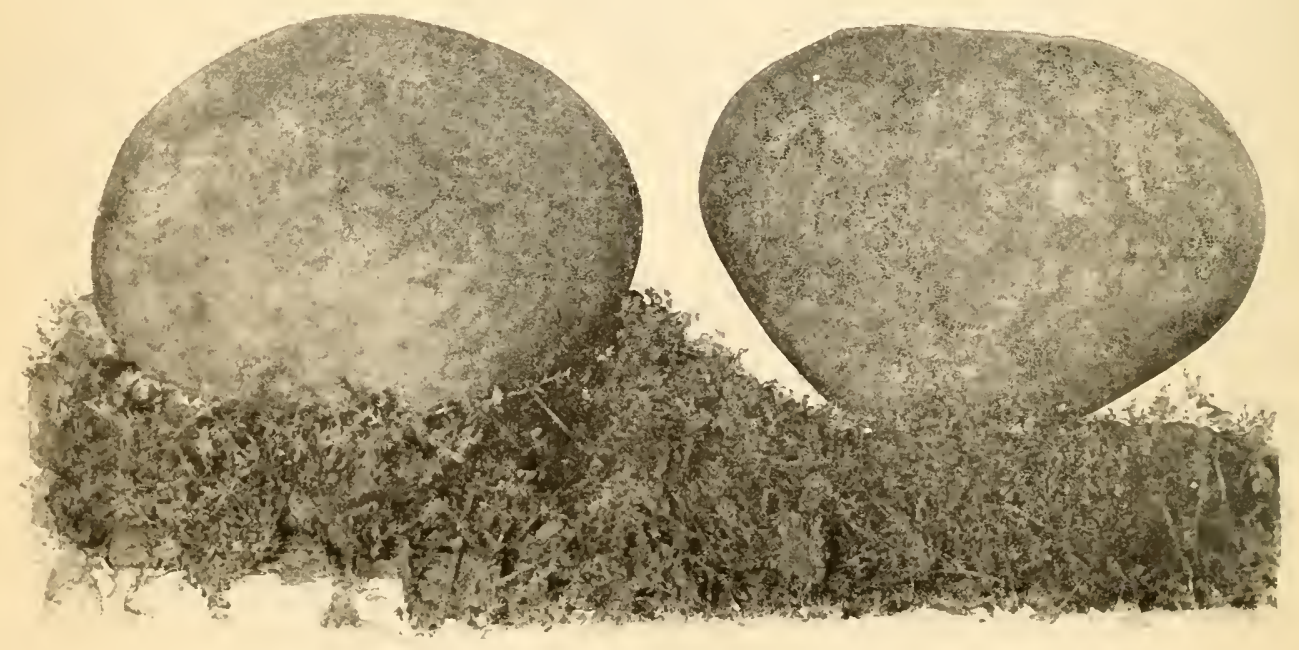

CUP.SHAPED CALVATIA (EDIBLE)

(Calvatia cyathiformis, Bosc)

Reduced. Nat size: Ball diam., 2 $2 / 8$ inches 


\section{Genus Geaster}

\section{GENUS BOVISTELLA}

The genus Bovistella contains but one species.

\section{Bovistella Ohiensis (Edible) (See Plate Facing Page 128)}

Peridiun or Pouch-Globose or broadly obovoid, sometimes much depressed, wrinkled underneath, with thick cord-like base.

Bark or Outer Coat-Dense, floccose, or with soft warts or spines.

White or greyish, drying to buff colour, and falling away.

Inner Coat-Smooth, shining, pale brown or yellowish surface.

Subgleba-Cup-shaped, broad, ample, occupying nearly one-half the peridium; long, persistent.

Spores and Capillitium-Loose, friable, clay colour.

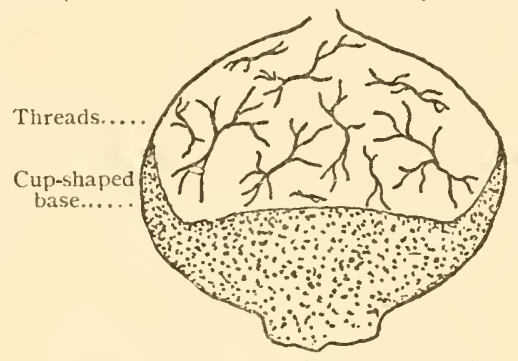

Section of Boristella (diagrammatic)

Threads free, short, twice branching, originating within the spore mass, and having no connection with the tissue of the inner coat.

Habitat-On ground in pastures and open woods.

\section{GENUS GEASTER}

\section{Earth-stars}

The Geasters or Earth-stars are the most picturesque forms of the puffballs. At first they are sunk deep in the soil, and are connected with it by abundant thread-like mycelium, which issues from every part of the surface. In the earth-stars the covering to the pouch is double, the outer cover is thick and leathery, and at first closely invests the inner coat, but is separate from it. At maturity the outer coat breaks its connection with the mycelium in the soil and bursts to form separate lobes, which become reflexed and lift the inner ball from the ground into the air, where it remains, seated at the centre of the expanded star-

bō-YYYs-těl'-lă
Ō-hī-ěn'-sis

129 


\section{Puff balls}

like coat. The coat of this ball is thin and papery, and opens by one apical mouth. The threads or capillitium, which bear the spores, project from the tissue of the inner wall and also from a central columella.

The Geasters have no economic value, but are rather interesting to the nature student on account of their beauty and their curious methods of discharging their spores.

\section{The Smallest Earth-star}

\section{Geaster minimms}

Peridium or Pouch-Globose, depressed, not pointed; vaulted underneatt.

Bark or Cuter Coat-Segments acute at the apex, many lobed; the lobes, seven to nine, expanding $1 / 2-1$ inch.

Inner Coat-Ovoid, $1 / 4-1$ inch in diameter, white to pale brown, with a distinct pedicel, seated in a plain circular disk.

Mouth-Lifted on a cone, lip bordered with hair-like fringe.

Spores-Brown, globe-shaped, minutely warted.

Threads-Transparent.

Habitat-Grassy grounds.

\section{Water-measuring Earth-star}

\section{Geaster hygrometricus}

Peridium or Pouch--Sub-globose, depressed, the bark or skin falling with the mycelium.

Bark or Outer Coat-Deeply parted; the segments, acute at the apex, seven to twenty. Strongly hygrometric, expanding to a breadth of $2-3$ irches.

Inner Coat-Globose, depressed, sessile, covered with a network. Whitish or greyish.

Mouth-Rim irregular.

Spores-Brown, globe-shaped, minutely warted.

Threads-Transparent, much branched and interwoven ; continuous with the hyphæ or threads of the inner coat.

Habitat-Fields and woods, in sandy soil.

The Geaster hygrometricus, or Astrans hygrometricus as it is called by some, is found all over the world. When the

$$
\text { MĬn'-Y-mŭs }
$$

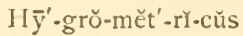




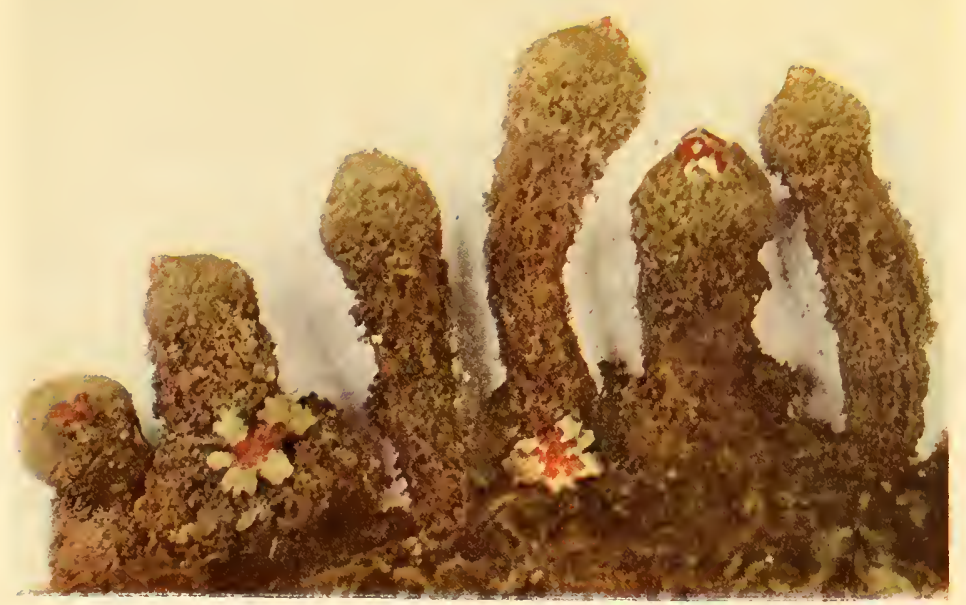

Calostoma Ravenelii (Berk.) Mass.

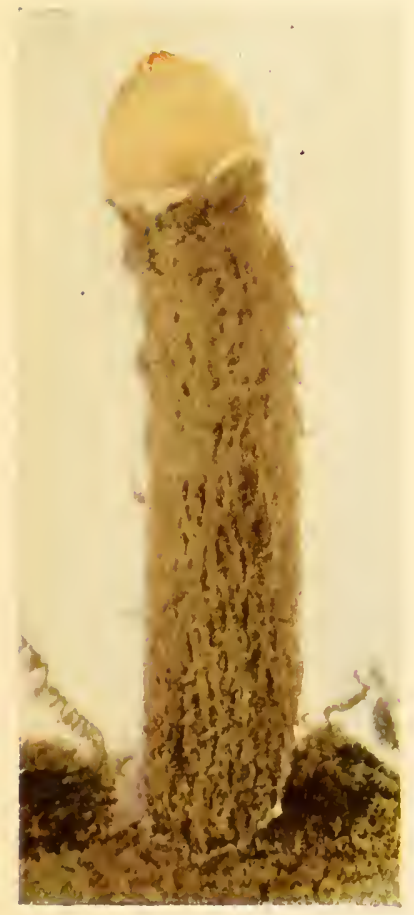

Calostoma lutescens (Schw.), Burnap.

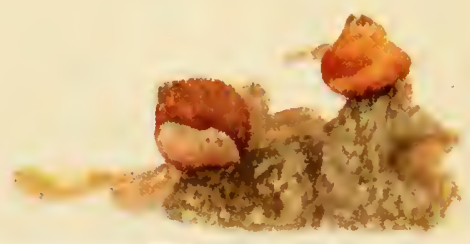

Calostoma cinnabarinum, Desv.

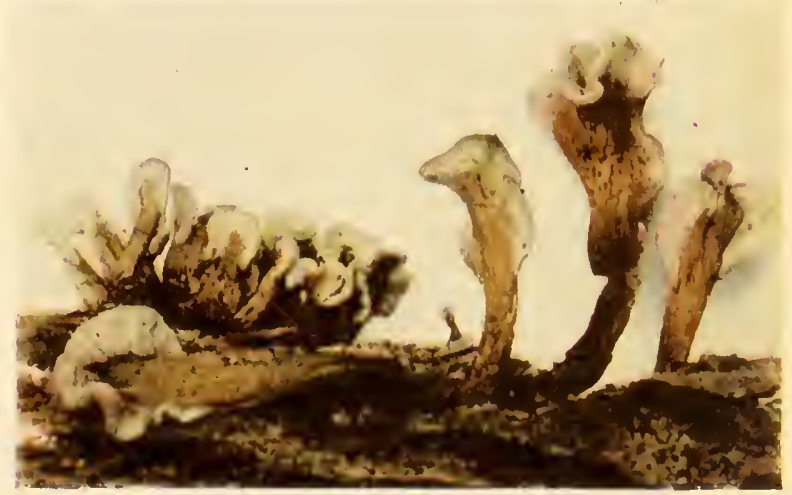

Spathularia velutipes, C. \& F. Reduced. See page 138. 

weather is wet, the lining of the points of the star become gelatinous and lie flat on the ground, anchoring the plant firmly; but when the weather is dry, the soft, gelatinous part becomes hard and rigid, and curls the segments up around the inner ball; then the wind rolls it about, and it scatters its spores from the hole in the apex of the ball as it rolls. It is a fair-weather traveller, always resting at night and on damp days.

\section{GENUS CALOSTOMA}

This genus has but three known American species. The plants are remarkable in structure and substance. The spore mass or gleba lies at the centre of a base, and is in its young stages surrounded by four layers. The outermost coat is gelatinous, and soon disappears. This is known as the volva or wrapper. The layer just within the wrapper also soon disappears; it is known as the exoperidium. The layer just within the exoperidium is known as the endoperidium, and is the layer seen on the exterior of older specimens. Between the exoperidium and endoperidium is a layer of red threads, part of which is torn away when the exoperidium breaks, and a part of which remains as a red star at the apex of the ball.

The exoperidium is cartilaginous; it is thin and fragile when dry, but when wet it is flexible, translucent, and soft. The endoperidium is hard and rigid when dry, and is conspicuous for the brilliant red which shows at its mouth. Within the endoperidium is a sac which contains the spores; when the spores are mature, this sac contracts, and forces the spores out into the air. The mycelium, or vegetative part of the Calostoma plant, is composed of numerous cord-like fibres, translucent, jelly-like, and tough, which, branching and anastomosing into a dense network, form a rooting columnar base to the spore-hearing part of the plant. The name Calostoma means beautiful mouth, referring to the red star which surrounds the opening through which the spores escape.

Căl-ŏs'-tŏ-mă 
Puffballs

\section{Calostoma lutescens}

Ball or Peridium-Globular, with a thick, entangled, rooting base. Outer Coat or Exoperidium-Dingy yellow, rupturing so as to form a ragged collar at the base, a thin cap on the summit, and small fragments between. The cap is marked on the under side with a vermilion star outlined with yellow.

Inner Coat or Endoperidum-Smooth, globular. Pale yellow. Mouth-With several rays of a bright red colour.

Footstalk-Thick, of entangled strands finer than those of C. cinmabarimum. Stem long, yellowish green.

Spores-Globular, with protuberances.

\section{Calostoma Ravenelii}

Ball or Peridium-Globular, with a thick, entangled, rooting base. Outer Coat or Exoperidium-Cartilaginous, gelatinous. Fragments remain upon the inner coat in the form of irregular warts or scales.

Inner Coat or Endoperidium-Yellowish. Tough when wet, rigid when dry.

Mouth-Red starred.

Footstalk-Short and rooting, composed of mycelial threads netted to form cartilaginous cords.

Spores-Elliptical, oblong, smooth.

\section{Calostoma cinnabarinum}

Outer Coat or Exoperidium-Vermilion within, breaking at the base and sometimes at the apex.

Inner Coat or Endoperidium-Yellowish, often slightly vermilion. Smooth.

Mouth-Rays several. Vermilion.

Footstalk-Reddish brown or brownish.

Spores-Elliptical oblong, spined or punctured, pale ochre yellow. 


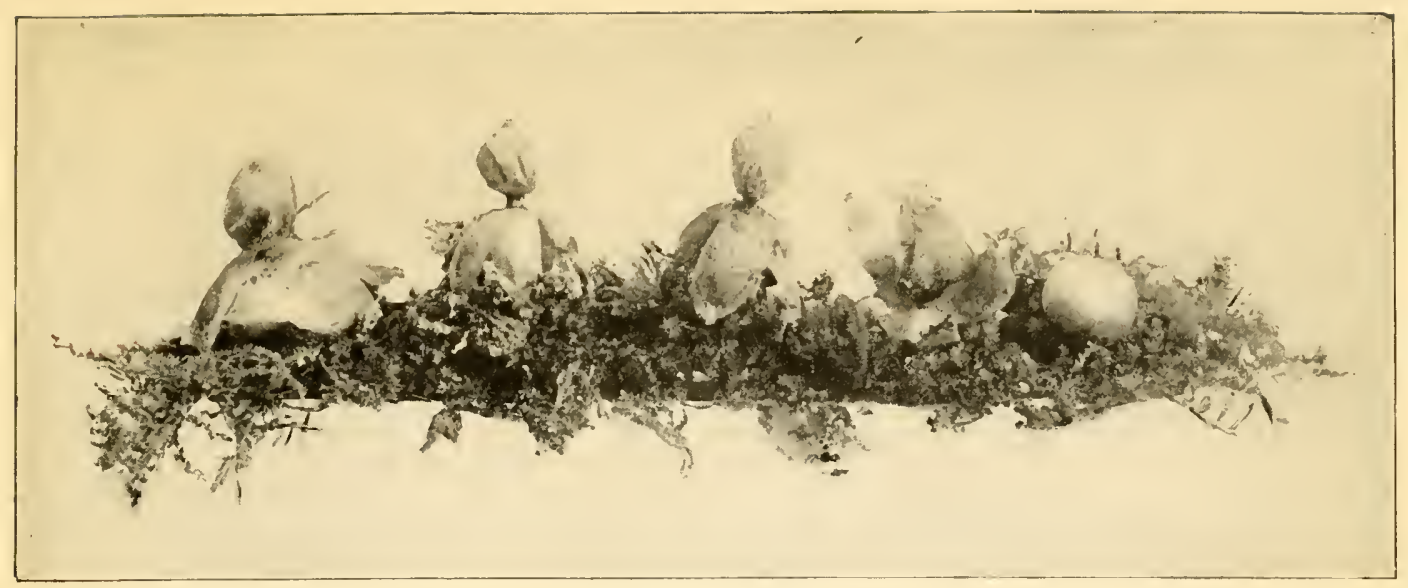

LEAST EARTH-STAR

(Geaster minimus, Schw. Nat. size:

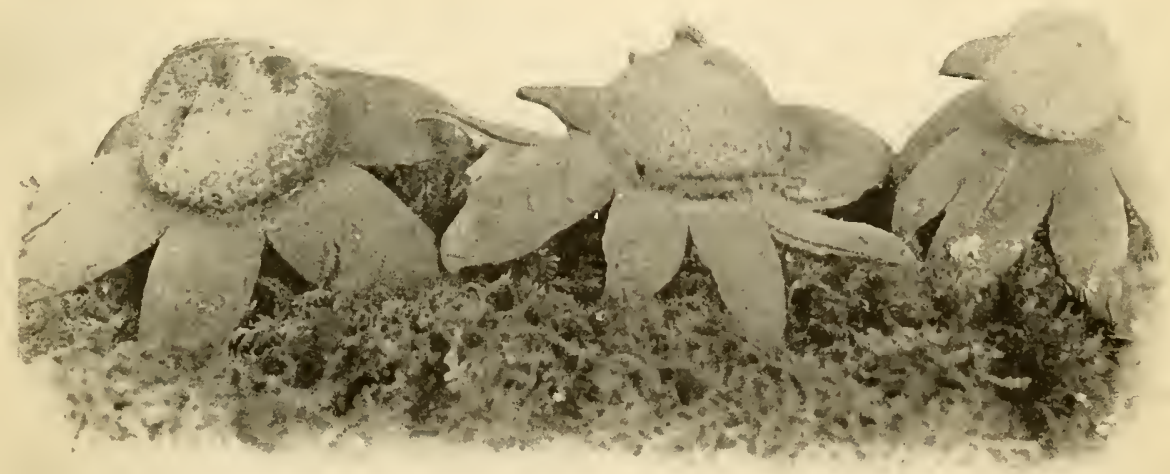

WATER-MEASURING EARTH-STAR

(Geaster hygrometricus, Pers. Nat. size)

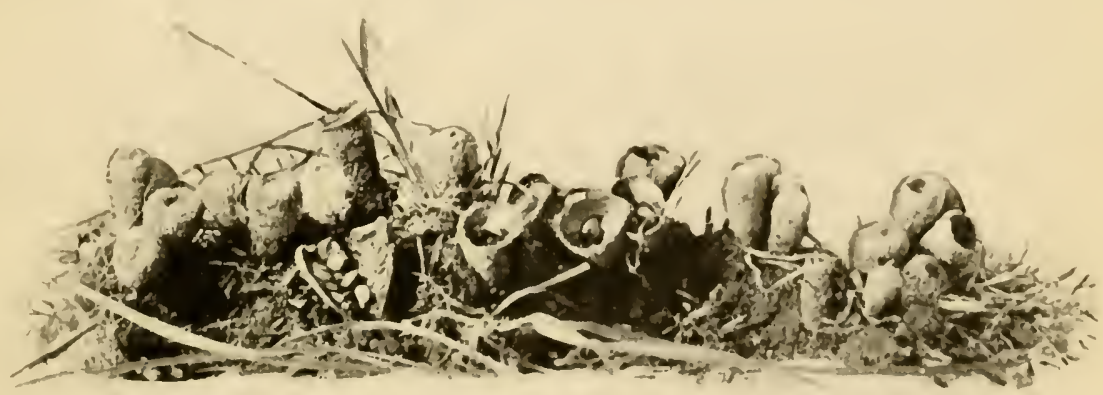

BIRD'S NEST

(Cyathus z'eruicosus, D. C. Nat. size)

See page 133 



\section{ORDER NIDULARIALES}

The members of this order, Nidulariales, or bird's-nest fungi, are curious fungi of small size. They resemble, when mature, tiny birds' nests containing eggs, as the pouch in which the spores are developed opens at the top to form a nest or bowl or trumpet, and the globular cases in which the spores are contained have strong walls, and remain in the open pouch like eggs in a nest.

One genus of the order, Sphcerobolus, has two walls or layers to its nest and but one spore case or "egg." This "egg" is jelly-like, and is forcibly thrown from the nest when the spores in it are mature. While a part of this action is due to the mechanical working of the teeth, it is thought that underneath the spore case gases are formed which expand, and so help force out the " egg."

The other genera have but one wall to their nests. The genus Nidularia has ragged edges, the genus Cyathus is trumpetshaped, and the genus Crucibulum is bowl-shaped.

\section{ORDER SCLERODERMATALES}

The puffballs of the order Sclerodermatales have the rind or peridium thick. The spores remain in the peridium until maturity, when they escape from an irregular opening in the rind. The species are not numerous, but some are abundant and widely distributed.

\section{GENUS SCLERODERMA}

The species of the genus Scleroderma, or thick-skinned puffballs, represent a transition from the subterranean forms to those which emerge from the ground and have a definite opening from which they eject their spores. To illustrate: there is one group (Hymenogastrales) in which the species remain in the ground,

\begin{tabular}{|c|c|c|c|}
\hline 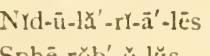 & NYd-ū-lă'-rY-ă & Crū-ç̧b'-ŭ-lŭm & Sclĕr-ŏ-dĕr ${ }^{\prime}-m \check{r}$ \\
\hline Sphē-rǔb'-ǔ-lŭs & Çy'-ŭ-thŭs & Sclěr'-ǒ-dĕr'-mŭ-tä'-lēs & \\
\hline
\end{tabular}


even when mature, unless washed out by rains or nosed out by animals, and which rely upon being crushed by accident or upon the disintegration of their rinds to free their spores. All true puffballs push themselves out of the ground before the spores are mature, and then, by rupturing the skin in a definite manner when mature, disperse their spores. The thick-skinned puffball goes a step farther than the first mentioned and emerges from the ground; but it remains behind the true puffballs, which disperse their spores from a definite opening, for it ruptures the skin irregularly.

\section{Scleroderma vulgare (Edible)}

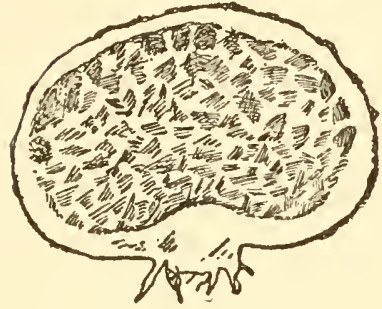

Section of S. vulgare

Peridium or Pouch-Rough and warty; depressed, globose. Pinkish to buff, remaining solid until the fungus is quite old. Sessile or with a rooting base. Ruptures irregularly to scatter the spores.

Subgleba-None.

Spore Mass-Lead colour marbled with white.

Habitat-Old stumps and buried roots.

This fungus has been eaten without harm, but is pronounced very unattractive.

Vǔl-gā'-rē 



\section{CHAPTER XII: SPORE-SAC FUNGI- ASCOMYCETES}

Aul the fungi which belong in the class Ascomycetes develop their spores in little membranous sacs called asci. These asci are, as a rule, collected, together with slender empty asci, called paraphyses, in variously shaped bodies, known in different orders by different names, such as perithecium, ascoma, apothecium, and receptacle. This class includes in its numbers individuals ranging in size from microscopic onecelled plants to conspicuous and often beautiful specimens. We shall concern ourselves with but a few of

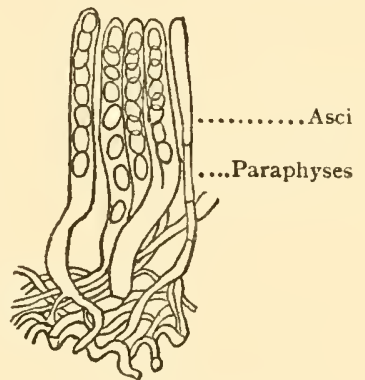

Asci and paraphyses those conspicuous ones which are attractive either from an edible or an artistic standpoint.

\section{ORDER TUBERALES - TRUFFLES}

The order Tuberales contains the truffles, which are subterranean fungi, ranging in size from an acorn to a good-sized po-

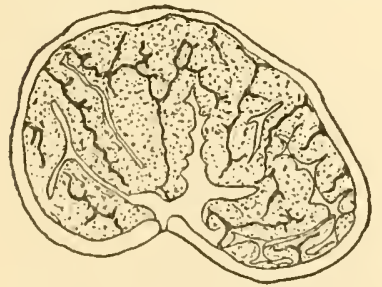

Section to show position of asci

tato. The asci or spore-sacs are formed on the interior of the fungus, the warty truffle itself being called an ascoma, as it contains the

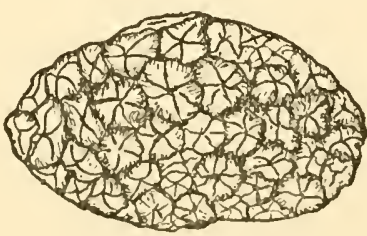

Truffles, ascoma asci.

Since the time of Pliny and Dioscorides, truffles have been known and esteemed as a table delicacy. Since they mature 
underground, they must be hunted for by dogs and pigs trained for the purpose. A pig will scent a truffle at a distance of twenty feet, and will run quickly to the spot to dig it out with her snout. An attendant must follow the pig to secure the truffle before the pig eats it. Edible species have not been found growing in this country.

\section{ORDER HYPOCREALES}

The order Hypocreales contains certain fungi which are parasitic on other fungi, and also on insects. In the genus Cordyceps there is a club-like form about an inch long, and of a rich red colour, which lives as a parasite on the pupæ of various moths buried beneath dead leaves. In New Zealand a similar fungus lives on caterpillars. The mycelium in time replaces the body, but maintains outwardly the form and appearance of the caterpillar. These growths are much prized by the natives as food. The form which grows on the truffle-like Elaphomyces is shown in the species of Elaphomyces upon which the Cordyceps lives as a parasite grow two or three inches below the surface of the ground, and somewhat resembles a truffle in appearance.

\section{ORDER SPHARIALES}

(See Plate facing Page 116)

The Xylaria pictured is a woody fungus which is common, growing on logs or at the bases of trees or stumps. The collections of asci (perithecia) are fully imbedded in the fleshy part of the fungus (stroma), which is formed almost wholly of hardened mycelium.

Hy̆-pǒ-crě-ā'-lēs Cŏr'-dy̆-ç̌ĕps $\bar{E}^{\prime}$-lăph-ō'-my̆-cēs 136 


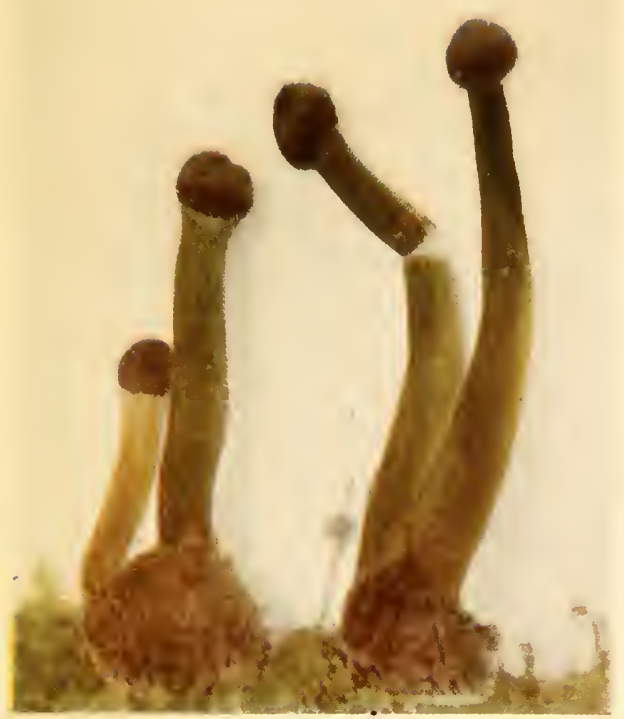

Cordyceps capitala (Holmsk.), Lk.

(Parasitic on Elaphomyces.)

Reduced.

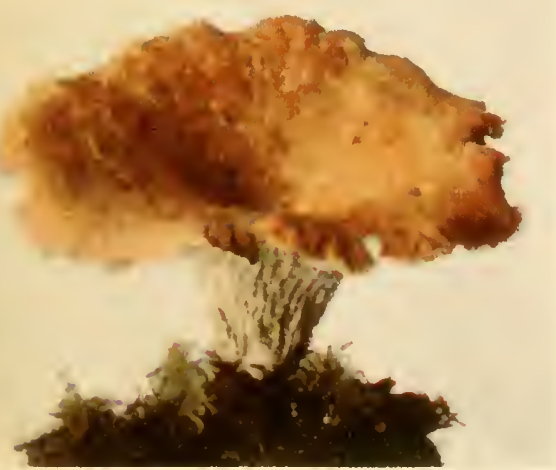

Floccose Chanterelle (edible). (Cantharellus floccosus, Schw.) See page 53.

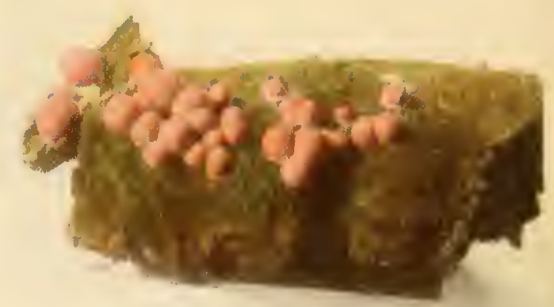

Lycogala epidendron.

Reduced. See page 144

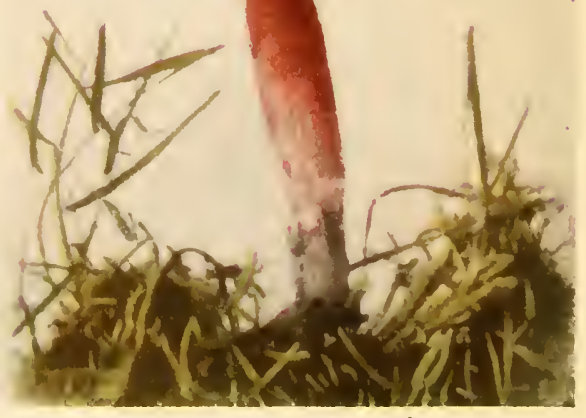

Mutinus Caninus, Huds. $S$ " page 120. 




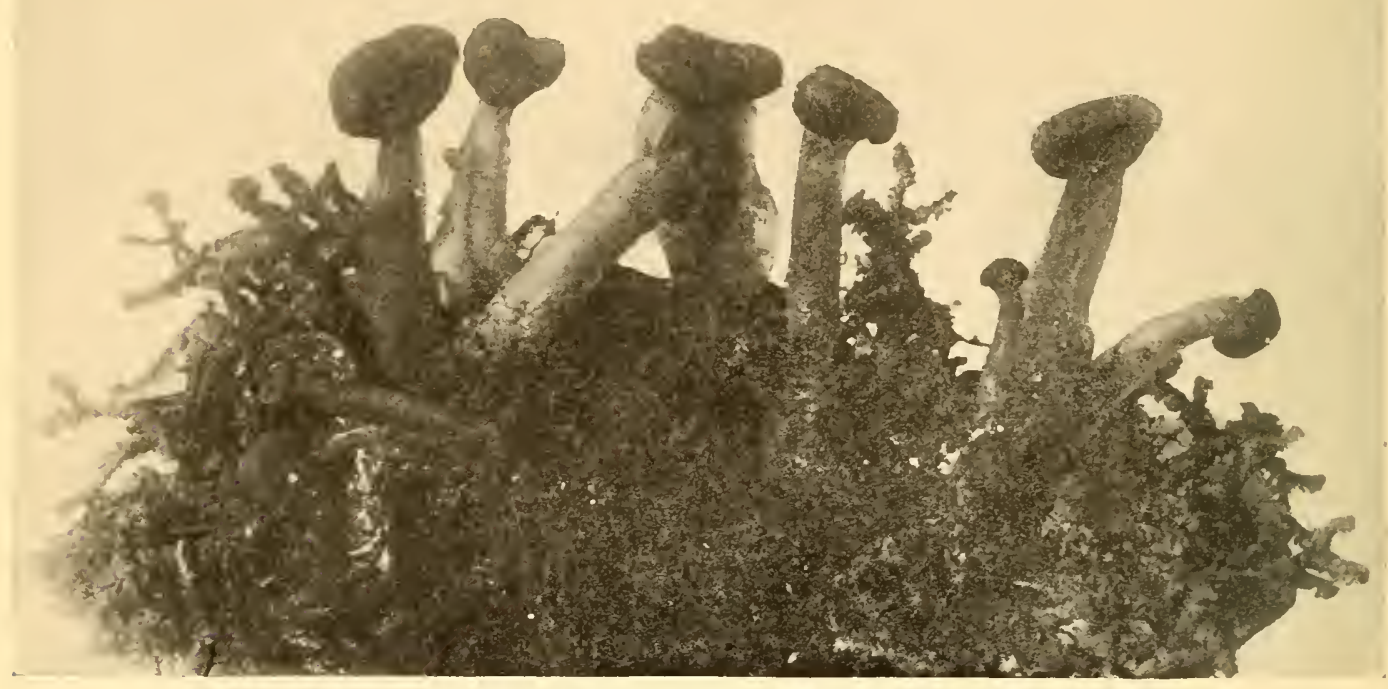

SLIPPERY LEOTIA (EDIBLE)

(Leotia lubrica (Scop.), Pers.)

Gelatinous, gristly ; spore-bearing body (ascoma), green or yellow; stem yellow Family, Geoglossacea. Class, Ascomycetes. Order, Helrellales. See p. $13^{8}$

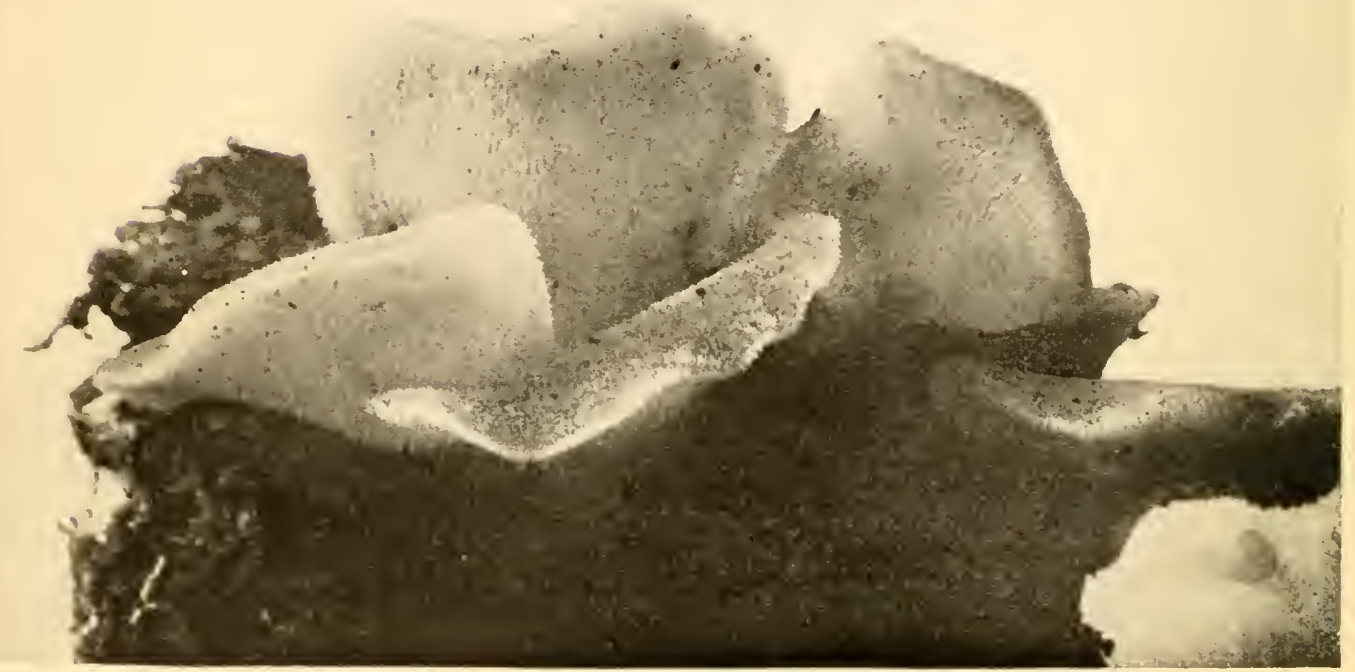

JELLY-LIKE TREMELLODON (EDIBLE, MCl.)

(Tremellodon gelatinosum)

Surface white to grey: teeth white. Class, Basidiomycetes. Order, Tremellales. See Genus, D. II6 


\section{ORDER PEZIZALES-CUP FUNGI}

The Pezizales or cup fungi, which are typically disk or cupshape, comprise an extensive group, and vary in size from forms scarcely visible to the naked eye to forms several inches in diameter. One genus, Peĩ $i a$, has a smooth ascomata, regularly saucer-shaped or cup-shaped. The genus contains many species which are met with chiefly on decaying vegetable matter. The spore-sacs are situated on the upper surfaces of the cups, and the spores are ejected with such force and in such profusion that they form a cloud around the plant from which they are expelled.

Peziza aruginosa is a stalked green form, and is interesting because it permeates the wood of oaks and beeches with its mycelium, and gives a rich green colour to the wood, which makes it valuable for the manufacture of the famous "Tunbridge ware." One may often find the wood affected when the fruit cups are not evident. Peziza Willkommii produces on larch trees a disease known as the "larch canker," which shows itseif as a sunken, blistered hole from which resin flows. This patch is formed because the mycelium of the fungus attacks and destroys the cambium or green layer which lies under the brown bark, and since this is the tissue which builds up the wood of the trees, the growth of wood in this part is prevented. The fruits appear above the bark in the form of little cups, white outside and scarlet within. When branches bearing golden-yellow needles are seen among the fresh green shoots of a larch, prematurely giving to the tree an autumnal appearance, one may expect to find Peziza Willkommii at work.

\section{Peziza odorata (Edible)}

Cup-Yellowish, translucent, becoming dull brown when old. The flesh is moist and watery, and separable into two layers; the outer layer rough, and the inner smooth. The frame is cup-shaped when young, but flattened and split on the margin when old.

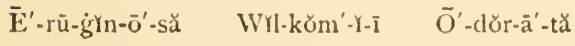

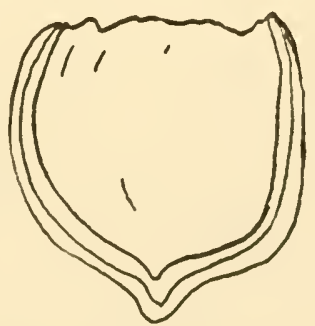

Section to show two layers 
Stem-None.

Habitat-The specimen pictured was found in December, among the violets in a cold frame in New Jersey.

\section{Golden Peziza (Edible)}

\section{Peziza aurantia}

Cup-Orange red within, golden or whitish outside, with a frosted appearance. Subsessile, irregular.

Habitat-In clusters on the ground, usually in the autumn.

\section{ORDER HELVELLALES-EARTH-TONGUES}

The order Helvellales contains the fleshy spore-sac fungi which have the spore-bearing body, the ascoma, open from the earliest stage of its development.

\section{FAMILY GEOGLOSSACE E}

The family Geoglossacea, which belongs to this order, contains the earth-tongues, which are club-like forms, green or black or yellow, and from one to three inches high, common on the ground, growing in rich wood mould. In consistency they are fleshy, gelatinous, or waxy, and their asci open by means of a terminal pore.

\section{GENUS SPATHULARIA}

The genus Spathularia has the spore body flattened and growing down both sides of the stem.

\section{Velvety Spathularia}

\section{Spathularia velutipes (See Plate Facing Page 132)}

Spore Body-Flattened, tawny yellow, shaped like a spatula, with the spore surface wavy and growing down two sides of the stem.

Stem-Hollow, minutely velvety, dark brown tinged with yellow. Flesh-Firm and tough, shrinking little in drying.

Habitat-Mossy trunks in damp woods.

Au-răn'-shr̆-ă

Vë-lū'-tř-pës 


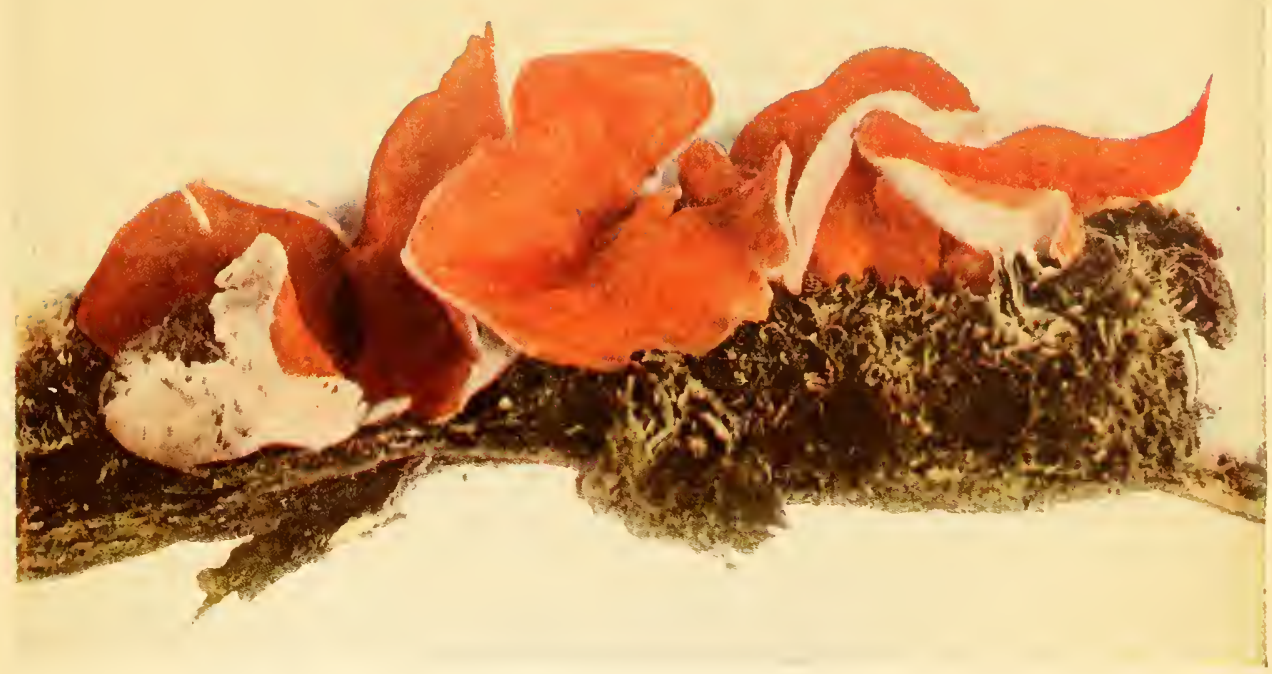

Golden Peziza (edible).

(Peziza aurantia, Pers.)

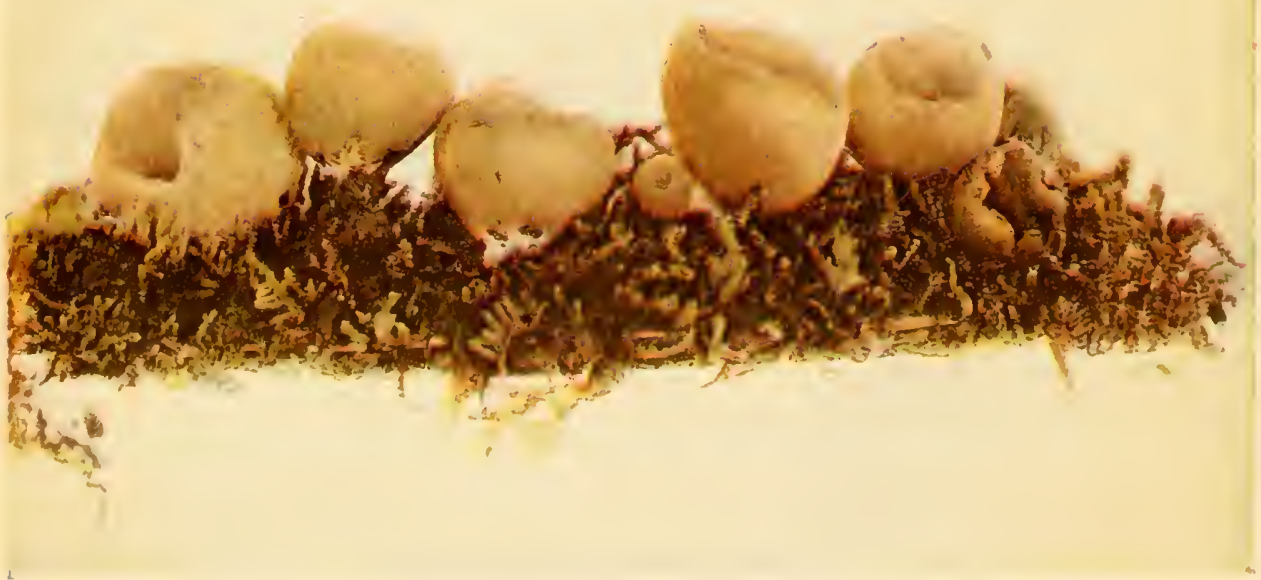

Peziza odorata. Pk. (edible).

Reduced. See page 137. 



\section{Spathularia clavata}

Spore Body-Clear yellow, shaped like a spatula, sometimes tinged with red. Obtuse or cleft at the apex, the surface wavy, the margin crisped, growing down the stem some distance on opposite sides; hollow.

Stem-Thick, hollow. White, often becoming yellowish. Flesh-Dry.

\section{GENUS GEOGLOSSUM}

The genus Geoglossum has the spore body simple, erect, and club-shaped, and entirely black. The spore surface is terminal.

\section{Geoglossum hirsutum}

Geoglossum hirsutum is black, dry, and everywhere velvety. Lanceolate, ovate, oblong, or almost round, often irregular. The spore-bearing portion is one-quarter to one-half the length of the fungus.

\section{Geoglossum glabrum}

Geoglossum glabrum is dry, black, or brownish black, sometimes tinged with olive or purple. Club-shaped or sometimes laterally compressed. The spore-bearing portion not sharply distinct from the stem below.

\section{GENUS VIBRISSEA}

The genus Vibrissea contains fungi with vertical and simple stems, and horizontal caps with their thick margins rolled in toward the stem. The spore-sacs are borne on the upper surface.

\section{Vibrissea truncorum}

Vibrissea truncornm is a clear orange-red or sometimes yellow or brownish-red fungus, about an inch high, found on decayed wood, branches, or leaves which are submerged in water.

Clăv-ā'-tă
Gē-ō-glŏs'-strm
IIYr-sü'-tŭm

Glā'-brūm
Vi-brY's'-sě- Ẋ 'Trŭn-cō'-rŭm 


\section{Vibrissea circinans}

Vibrissea circinans is a pale yellowish flesh colour, or simply yellowish fleshy fungus found growing in circles or clusters, with convex caps and incurved, wavy margins, the concave under surface often minutely wrinkled. The stem is long, pallid, or reddish. The plant is found chiefly in pine woods.

\section{GENUS MITRULA}

The genus Mitrula has the spore body erect, black or bright coloured, and dry, spatulate, or cylindrical, often compressed laterally. The spore-bearing surface is sharply distinct from the scaly or mealy stem below.

\section{Irregular Mitrula (Edible)}

\section{Mitrula vitellina, var. irregularis *}

Spore Body-Bright egg yellow. Club-shaped, somewhat lobed, cylindrical or compressed; apex narrow, obtuse, smooth. No two plants are quite alike. Length, $\mathrm{I}-2$ inches.

Stem-Short, white, rather distinct, covered with fibres. Spongy and white within.

Habitat-In mossy places in woods during the autumn. The specimen pictured was found growing among fallen birch leaves, hemlock needles, and moss, in the dense woods at Lake Placid.

\section{FAMILY HELVELLACEAE-MORELS}

A second family Helvellacea contains three important genera, Morchella, Gyromitra, and Helvella, in which are the largest and most highly prized spore-sac fungi known. They are distinguished from the earth-tongues by the cap-like form of the spore body or ascoma, but especially by the character of the spore-sac, which opens by a little lid instead of by a simple pore.

\begin{tabular}{|c|c|}
\hline Çir-ç̌r'-năns & Vĩ'-těl-1ī'-nă \\
\hline MYtt'-rŭ-lă & Mŏr-kěl'_lă \\
\hline
\end{tabular}

* This species is also described under the names Geoglossum irregulare and Geoglossum vitellinum. 


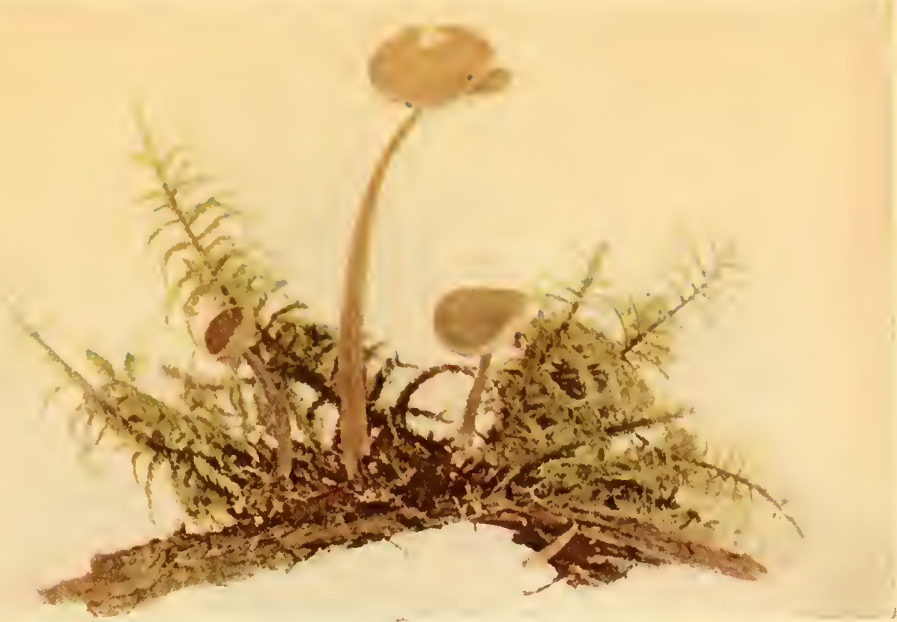

Helvella elastica, Bulf. Reduced. See page 142.
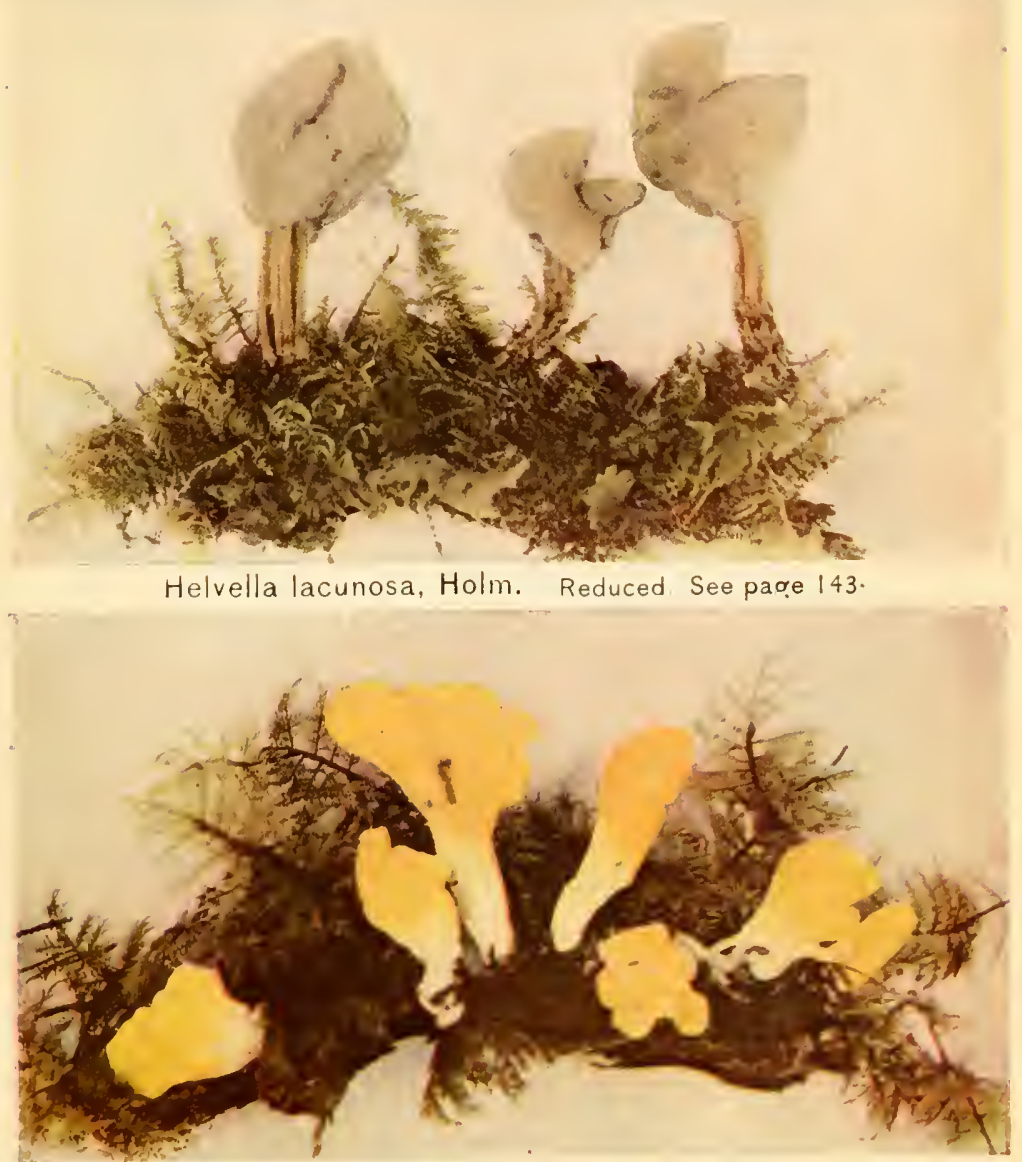

Mitrula vitellina, sacc., var irregularis, Pk. (edible). Reduced. 



\section{GENUS GYROMITRA}

The genus Gyromitra contains seven species. These have the ascomata distinctly stalked, and the upper surface covered with gyrose folds. The largest spore-sac fungi belong in this genus.

\section{Gyromitra esculenta (Edible)}

Cap-Bay red, round, lobed, irregular, gyrose-wrinkled, attached to the stem in several places. Hollow, white, and uneven within.

Stem-Whitish, hollow, scurfy. Two or more inches long.

Flesh-Edible only when young and freshly gathered.

Habitat-In sandy soil, during the wet weather of May and June.

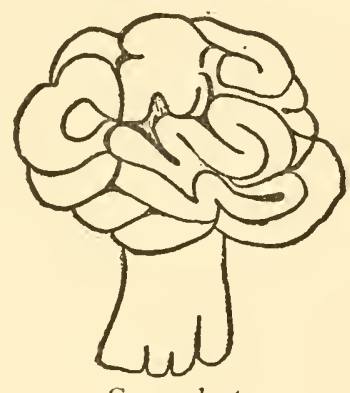

G. esculenta

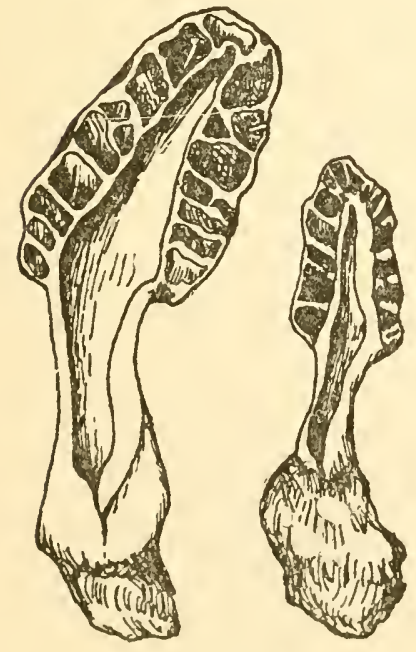

M. deliciosa

Section to show margin of the cap united to the stem.

\section{GENUS MORCHELLA}

The genus Morchella has the cap covered with a network of blunt ridges enclosing irregular depressed spaces. The spore-sacs are developed in both ridges and depressions. All the species when young are of a buff yellow tinged with brown, but later they are darker. The stems are rather stout and hollow, white or whitish in some species, and attached to the cap at the apex only; but in others, attached to the rim as well. All the species

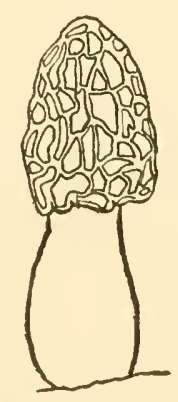

M. esculenta 
are edible and highly esteemed. They must be looked for during wet weather, early in the season. They may be classed in two groups, according to the attachment of the stem.

\section{l-MARGIN OF CAP UNITED TO THE STEM}

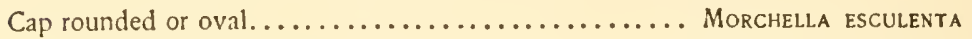

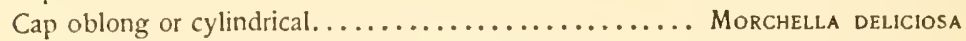

Cap conical or oblong conical ; broader than stem...... MorChella CONICA

Cap conical or oblong conical; scarcely broader than stem. MorChella ANGUSTICEPS

\section{II-MARGIN OF CAP FREE FROM THE STEM}

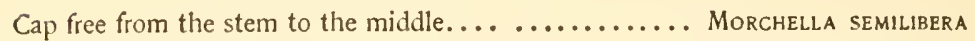

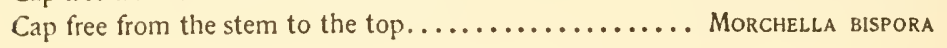

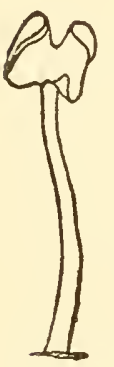

\section{GENUS HELVELLA}

The genus Helvella contains twelve species. They all have lobed, irregular, or saddle-shaped caps, which are fleshy, and attached to the stem at the apex. They are contorted in such a way that no two of the species appear alike.

Helvella

\section{Helvella elastica}

(See Plate Facing Page 140)

Cap-Brownish grey. Cup-shaped, flattening out when mature ; when young, the under surface is covered with little spines or hairs. Both surfaces are smooth when mature.

Stem-Slender, of the same colour as the cap, tapering toward the cap. Solid and white within.

Habitat-The specimen pictured was found growing beneath hemlocks and yellow birches, in Lake Placid forest, during September.

$$
\begin{aligned}
& \text { Dĕ-IYsh-Y-Īó-să } \\
& \text { Cǒn'-Y-că }
\end{aligned}
$$

Ăn-gŭs'-tri-çěps

Sĕm'-1-lYb'-ĕr-ă
Pi'-spơr-ă

E-lăs'-tİc-ă 


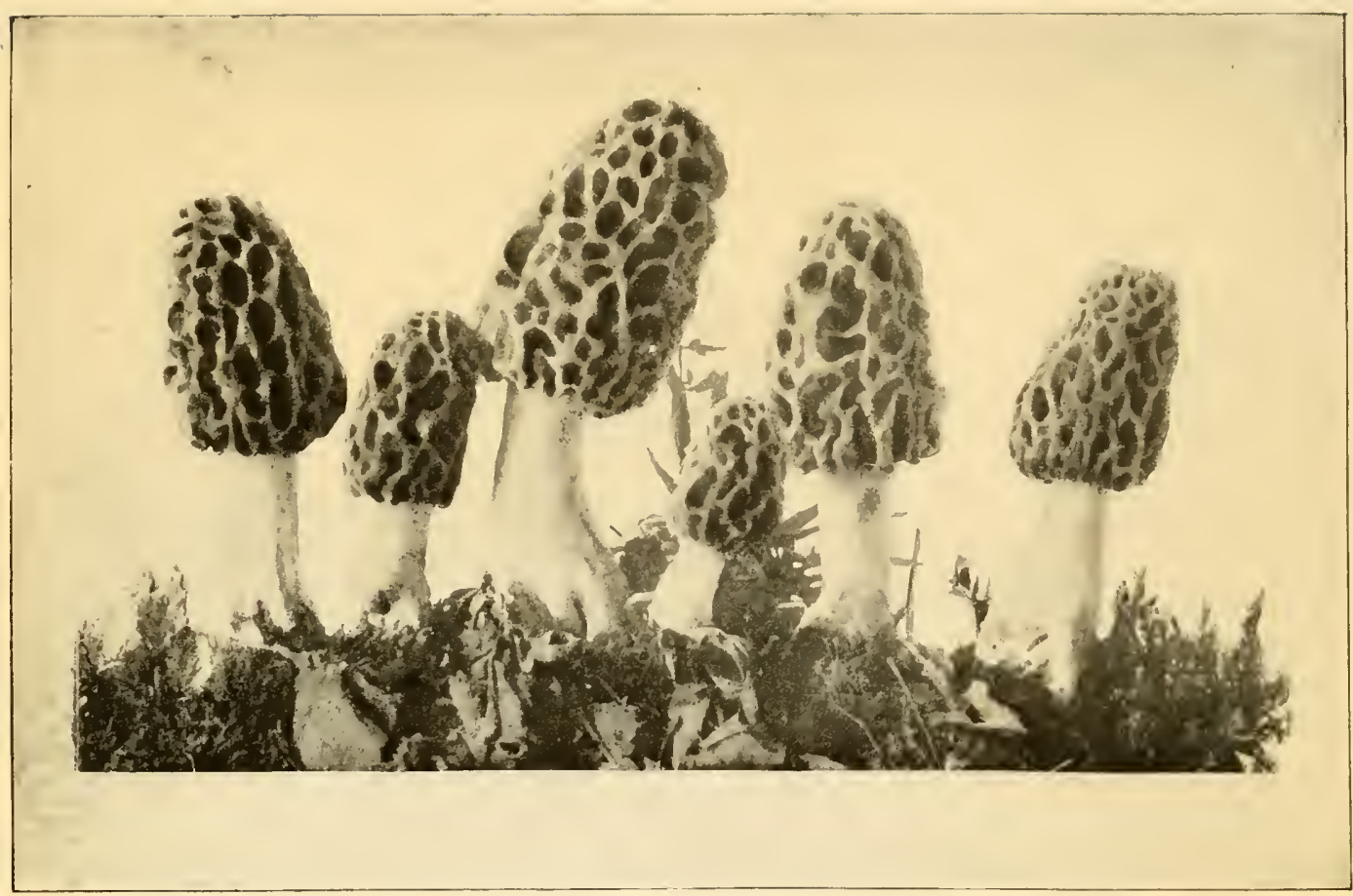

DELICIOUS MOREL (EDIBLE)

(Morchella deliciosa, Fr.)

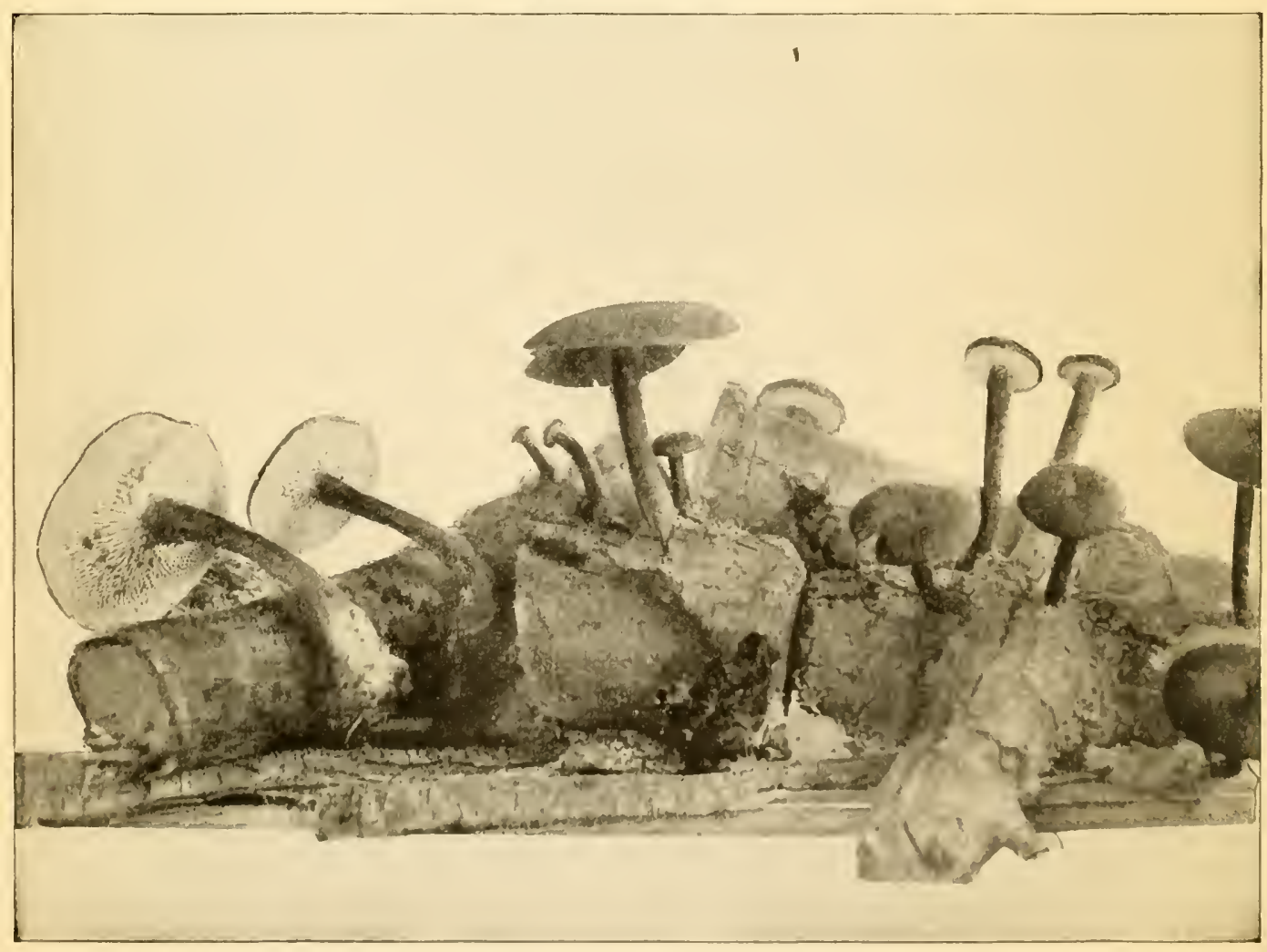



Helvella lacunosa (See Plate facing Page i40)

Cap-Of one piece, thin and flexible like rubber cloth, folded to saddle the apex of the stem. The two saddle-flaps are attached on their margins at irregular intervals when young, and are puffed out like a balloon; but when mature, the pieces separate. Their outer surface is brownish grey, and their inner surface light grey, creased and folded.

Stem-Irregularly and deeply furrowed.

Flesh-Odour offensive.

Habitat-The specimen pictured was found growing imbedded in deep moss on old bark in the Lake Placid woods.

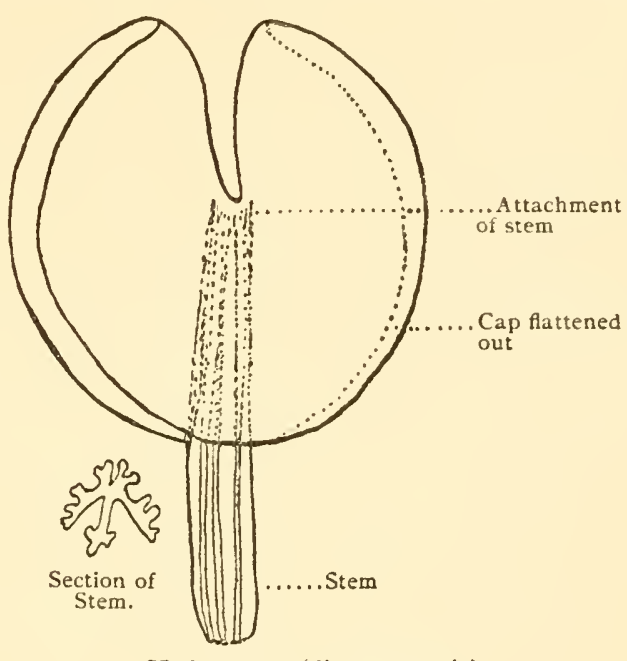

H. lacunosa (diagrammatic) 


\section{CHAPTER XIII : SLIME FUNGI-MYXO- MYCETES}

(See Plate facing Page 136)

WHETHER the slime fungi are plants or animals is a question not yet decided. They are living organisms which have no chlorophyll, or leaf-green, and which in their vegetative state resemble certain groups of the Protozoa, or unicellular animals, which live in water. In their manner of reproduction they show resemblances to certain fungi, and the spore cases or sporangia of some resemble tiny puffballs in form and manner of ejecting their spores.

In the growing stage they consist of a naked mass of yellowish or whitish protoplasm, which creeps about in the dark, in accumulations of dead parts of plants, or under the bark of rotting stumps or logs. When a spore germinates, the membrane about it bursts, and a bit of naked and slimy protoplasm escapes. This tiny mass creeps about, absorbing food from its surroundings, and increasing in size until it may perhaps cover an area of many inches. After a time spores begin to form, then either the whole mass is transformed into al single spore case or a number of spore cases are formed. The spore cases of Lycogala epidendron are pretty things, resembling pink coral beads. When fresh, a case is filled with a thin pink paste; but when mature, with fine brown dust-like spores. When the spore case bursts, these spores escape, and if they fall in favourable places the life cycle begins anew.

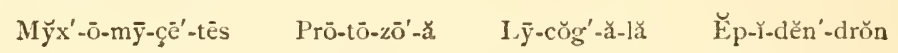





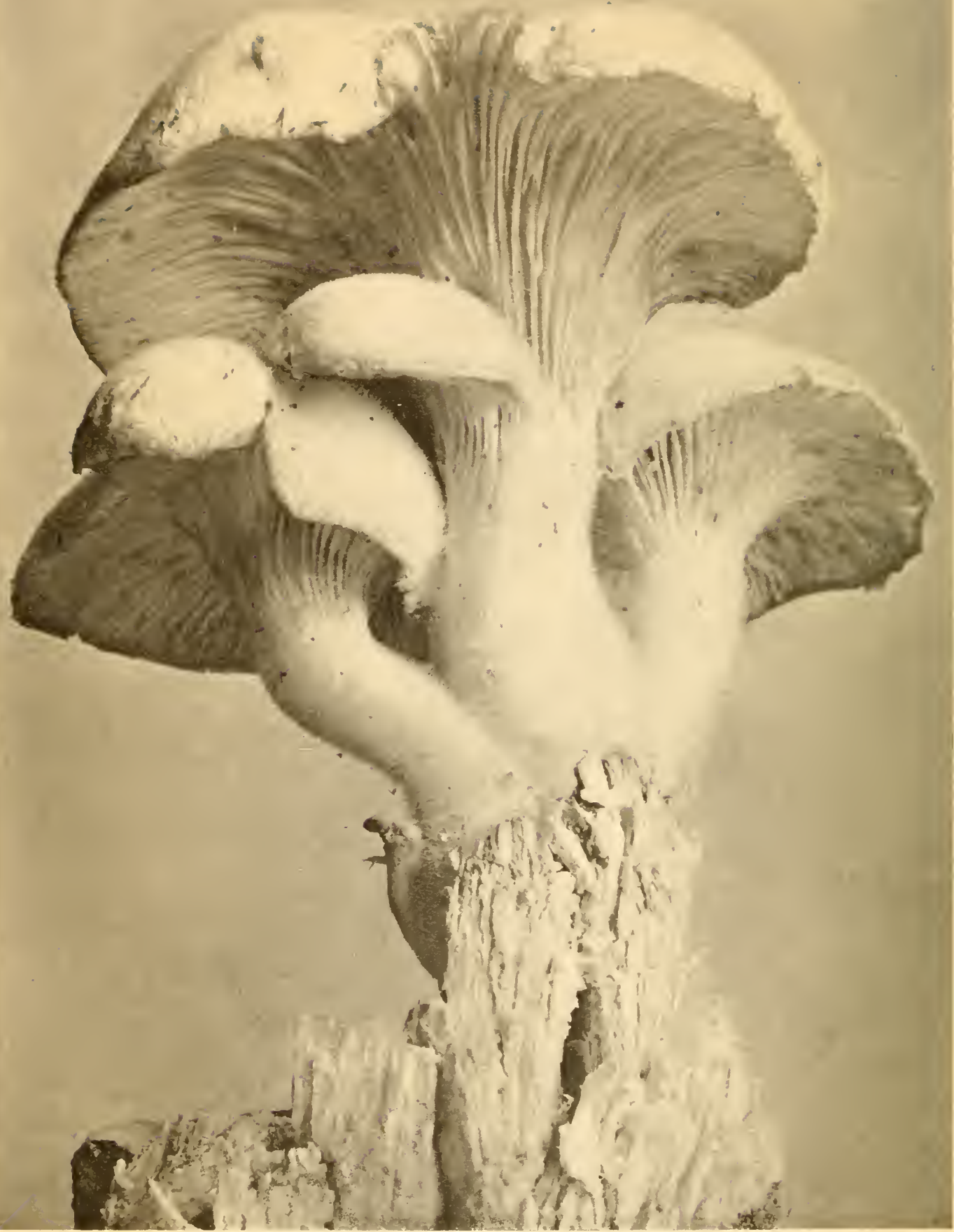

BRISTLY PANUS

(Panus strigosus, B. \& C.; Lentinus strigosus)

Cap, gills, and stem creamy. See Genus, p. 67 


\section{CHAPTER XIV : FUNGI FOR THE HERBARIUM}

THERE are no plants more difficult to preserve for an herbarium than the fleshy fungi, and yet my personal observation leads me to believe that there are many people who would be willing to undertake the task if they knew how to set about it; and there is no class of plants in which the assistance of the amateur may help the botanist more than in this, provided that, at the time of gathering a specimen, full descriptive notes are made of all the characteristics of the plant.

To aid one in quickly taking notes, it is well to have with one in the field some printed or written blanks. A convenient form is suggested by the following outline, which is the one used by the Boston Mycological Club :

\section{Collected by}

\section{Species}

\section{No. \\ Locality \\ Date}

\section{COLLECTOR'S NOTES.}

N.B.-When collecting, be sure to get the whole plant, base and all, uninjured; and to get young as well as mature specimens.

Note here at once the

Habitat. On $\left\{\begin{array}{l}\text { Tree (kind; dead or living). } \\ \text { Ground (kind of soil). }\end{array}\right.$

Place (wood, field, wet or dry, high land or low, etc.).

Under and near what trees?

Manner of $\{$ (Solitary, in clusters, troops, or cæsp̧itose [growing from one Growth. $\{$ root $\}$ ).

Character. (Viscid, hygrophanous [transparent when moist], dry.)

\section{Smell.}

Taste.

Spores. Colour.

Notr. - If the plant is perishable, sketch and describe it fully at once, and look 


\section{Fungi for the Herbarium}

for indications of spore colour. After the plant is described it may be dried in hot air (over a stove for instance) and preserved or sent in for identification.

Sketch the plant, indicating markings of cap and stem. Draw or trace a vertical section through the centre of cap and stem, indicating thickness of flesh; shape and attachment of gills; nature of interior of stem; position of ring, volva, etc. Do this also for a young specimen (button), showing whether the margin of the pileus is stiaight or incurved.

N.B.-If not life size, note dimensions.

When the characters vary with age or with moisture, note the changes.

\section{Pileus.}

Gills.

Flesh.

Stem.
Shape (flat, convex, concave, umbonate [raised in the centre], umbilicate [depressed in the centre], etc.).

Is it viscid when moist and fresh; tough, fragile, fleshy, membranaceous; smooth, floccose, scaly, silky, fibrillose; even, rough, wrinkled, furrowed? etc.

Is the margin entire, wavy, striate, inrolled, upturned, smooth, woolly, hairy, appendiculate? etc.

Colour and markings.

Shape.

Attachment (adnate, sinuate, decurrent, etc., or free).

Are they distant or crowded, all of one length, branching or forked, connected by veins?

Surface (smooth, powdery, marked in any way).

Colour (young and old).

Texture (thick, thin, brittle, etc.).

Margin (entire, wavy, scalloped, toothed, fringed).

With Boleti note colour, length, and size of tubes, shape and size of mouths, relation of pore surface to stem, etc.

Consistency (firm, mealy, punky, etc.).

Colour (in general; just under skin; near gills or tubes).

Juice (taste and colour).

Texture (tough, flexuous, fragile, fleshy).

Shape (tapering either way, straight or bent, swollen, etc.).

Exterior (cartilaginous, fibrous or not, etc.).

Colour and markings (striate, dotted, pruinose [with a bloom], fibrillose, or smooth, etc.).

Interior (hollow, solid, stuffed, fistulose [tubular], etc.).

Base (shape, markings, etc.).

$$
14 \mathrm{u}
$$


Mycelium (thread-like, cottony, compact, root-like, sclerotioid [hard], coloured).

Veil. (Examine young specimens).

Ring. $\left\{\begin{array}{c}\text { (Relative position, permanent or fugacious [quickly disappearing], } \\ \text { etc.). }\end{array}\right.$

Volva. (Examine young buttons, base of stem, surface of pileus).

\section{Remarks.}

Collector's Outfit.-For collecting fungi there is nothing better than a cheap splint basket with a cover. The size will depend upon the ambition and strength of the collector. In addition, a chisel for woody fungi and a trowel or broad-bladed knife will be found convenient; also a few small boxes for fragile species, and a package of thin, tough, uncoloured paper in which other specimens may be put. Sheets of six inches square and also of twelve by twenty-four are convenient sizes. Before the specimens are put in the basket, those of a kind should be compactly piled in the centre of a sheet, and the four corners of the sheet brought together and fastened by twisting them. The slip with the notes may either be put inside the package or fastened on the outside.

Care of SPECIMENS. - As soon as possible after reaching home, the packages should be taken from the basket and spread out in convenient places. If the specimens are to be used immediately for identification, begin with the most perishable, or they will be lost by decay. If they are to be preserved for future use, put them in the warmest place available where they will not burn. This may be under or over the kitchen stove, or in the furnace-room of the hotel or laundry; or, if any of these places is not practicable, then a drier may be improvised by placing over a lamp a frame made of wire screening.

Collecting Spores. - At least one specimen of each kind should be set for spores. This is readily done by thrusting the stem of one plant through a hole in a disk of gummed paper so that the paper fits closely against the gills. This disk may be held in place by thrusting the stem of the fungus through a piece of thin paper and then bringing the paper above the cap and twisting the corners. Use white disks for fungi suspected of having coloured spores, and coloured paper for those suspected of 
having white spores. If there is any doubt, set two fungi-one with a coloured disk and the other with a white one.

It is an easy matter to fix spores for future use, but a more difficult matter to fix them so that they represent a picture of the radiating gills. In order to do this the stem must be cut from the cap, and the cap must be so arranged over the paper that no draughts shall disturb the spores als they fall, and also so that it maly be removed from the paper without disturbing the spores after they have fallen. The writer would suggest that two fine wires should be thrust horizontally and at right angles to each other through the cap, and that the ends of the wires should be supported in a convenient manner, so that the cap may just swing free from the paper which is to receive the spores. The whole must be covered to keep the spores from being disturbed by draughts. When the spores have fallen, the cover can be removed, the cap raised, and the spore-print fixed.

Various methods of fixing spores for prints are recommended. The following are quoted from a bulletin of the Boston Mycoiogical Club :

The following directions for fixing spore prints are taken from Herpel ("Das Präpariren der Hutpilze").

Paper which is somewhat absorbent must be used; unglazed blue or black paper (of which the colour must be unaffected by the fixative) for white-spored species. The piece of paper bearing the spore print is to be laid, spores upward, in a flat plate or platter on which a thin layer of fixative has first been poured. The fixative is allowed to soak up through from below, and should not overflow the edges of the paper. When it is certain that the spores as well as the paper are thoroughly soaked, the preparation is removed and dried; sometimes, to prevent sticking, being laid on moistened blotting-paper.

The fixative to be used will vary with the species. For instance, the spores of Cantharellus cibarius and some others may be fixed by water alone. The following solution is recommended for Boleti and species with coloured spores: One part sandarac, two parts mastic, and two parts Canada balsam, dissolved in thirty parts of ninety-five per cent. alcohol. In the use of this it has been found that the time of soaking necessary to fix the spores is for Boleti, two minutes; Dermini, Coprinarii, Gomphidius, Paxillus, Russula, and Lactarius, four to five minutes; pink-spored agarics, also dark brown spored (as the meadow mushroom), and Cortinarii, six to eight minutes. It is important that the alcohol should be full strength.

A gelatine solution is useful for white-spored species. This is prepared and used warm. Its strength varies with the species. Lepiota frocera, Collybia radicata, and Clitocybe laccata may be fixed by a solution of one part gelatine to thirty of water. For species of Tricholoma this is too strong, and one to sixty, or one to two hundred must be the formula. The difficulty arises here from the fact that an excess of 
gelatine makes the spores transparent and even invisible. Their opacity may be secured by previous treatment with a solution of one part mastic in thirty of ether.

For certain kinds (Tricholoma personatum, Lepiota granulosa, Amanitopsis vaginata, and others which experiment will discover), ten to twenty-five per cent. of alcohol must be added to the gelatine solution in order to make the spores adhere.

Experience will doubtless show that other fixatives may be used. Gum arabic, for instance, suggests itself. This, however, if strong, is apt to cake the spores together. If one method fails, invention and repeated trials must find a successful means. Reports are requested from all who engage in the amusement of making spore prints. To these a suggestion not without value is that dry agarics (like Marasmius and some Collybias) may be kept in a condition to shed spores by putting moistened blotting-paper under them.

Another method of making spore prints is to spray them from an atomizer with a solution of white shellac in alcohol. A saturated solution should be made, and then diluted fifty per cent. with alcohol.

The Search for a Name. - When looking up a name for a plant, the best plan is to use fresh specimens, and, if a good supply can be had, make a careful comparison of all, so as to be sure that the characteristics are normal and not due to injury. If the attempt to find a satisfactory description is not successful, preserve the specimens dried, together with full notes, and send a part of them to the State botanist for determination.

The name of a fungus is not the vital thing. In pursuit of a name do not neglect the plant. Observe it as it grows and in its different stages. Make a friend of it, and you will find it good company.

The Preparation of Rough-dried Plants for the HerbaRium-Put the dried plants in a place where they will absorb just moisture enough to make them pliant. Either put them in a box containing something damp, as a wet sponge, sand, or paper; or spread them where they can absorb the moisture of the atmosphere without getting too wet. When pliant, bend the stem and cap so that they lie in the same plane, and arrange them in as natural a form as possible; then place them between driers of unglazed paper, with a weight just sufficient to keep them from curling out of shape.

Mounting-The specimens may be placed loose in envelopes made by folding paper as for mosses or lichens, or they may be glued directly to mounting sheets, or they may be kept in boxes of varying sizes. 


\section{Fungi for the Herbarium}

Sections-A section of a fungus is a very thin slice cut from the plant by running a thin-bladed knife from the top of the cap down through the stem. When well made, sections of young and mattre prants are caluable in addition to the notes and dried specimens. A section to be of any value must show the form of the cap; the attachment of the gills to the stem; the thickness of the stem; and the interior, whether solid, hollow, or stuffed. To preserve the section, it must be placed, while fresh, upon a sheet of gummed paper, and then covered with a sheet of waxed paper, and placed between driers, under heavy pressure.

Poisoning Herbarium Specimens-It will be found necessary to use every means possible to keep insects from the herbarium, as fungi are particularly subject to such pests. In order that no eggs and larvæ may be packed away with the dried plants, it will be well to apply a poisonous solution to the specimens just after they have been moistened to be put into press. Professor Peck, the State botanist of New York, uses a solution made by dissolving strychnine in warm water, and then adding alcohol in sufficient quantities to make the mixture spread easily with a brush.

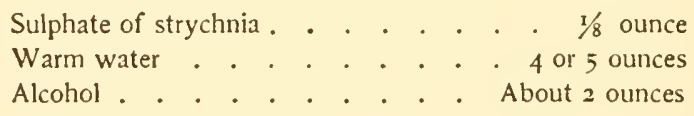

In addition to this precaution, the specimens must be kept where insects cannot get at them, or the havoc which they make will be disastrous. An ingenious person can improvise all the apparatus necessary for a successful collection of moderate size; and then, if his enthusiasm continues, he can provide himself with everything of the most improved style from dealers who make a specialty of botanical supplies. 


\section{CHAPTER XV : FUNGI FOR THE TABLE}

BEFORE you attempt to use fungi for the table be sure that they are edible; the consequences which follow a mistake are too serious to warrant any risks. Unless you are experienced in making careful observations and comparisons, eat only those fungi which have been shown to you by some one who has tried them and knows them to be wholesome. If you are experienced in making careful observations and comparisons, and wish to make experiments, make them cautiously, using a small quantity of the fungus for the first trial, and, if no ill effects are felt, increase the amount until you are satisfied as to its edibility.

There is no general rule by which one may know an edible species from a poisonous species. One must learn to know each kind by its appearance, and the edibility of each kind by experiment.

Some edible mushrooms change colour when bruised, some edible ones do not.

Some poisonous mushrooms change colour when bruised, and some poisonous ones do not.

Some mushrooms with bright colours, or viscid caps, or pleasant taste, or agreeable odour are cdible, and some are poisonous.

Some edible mushrooms will turn a silver spoon black, and so will some poisonous ones.

\section{Cautions for the Inexperienced}

Never use specimens which are decomposed in the slightest degree.

Never use those which are at all burrowed by insects.

Nerer collect, for food, mushrooms in the button stage, as it is difficult for al novice to distinguish the buttons of poisonous species from the buttons of harmless species.

Nerer use fungi with swollen bases surrounded by sac-like or scaly envelopes. 
Never use fungi with milky juice unless the juice is reddish.

Never use fungi with caps thin in proportion to the width of the gills when the gills are nearly all of equal length, especially if the caps are bright coloured.

Never use for food tube-bearing fungi in which the flesh changes colour when cut or broken, nor those with the tubes reddish. Be very cautious with all fleshy tube-bearing fungi.

Never use for food fungi with a web-like ring around the upper part of the stem.

The novice may safely experiment with Clavarias, coral fungi, morels, and puffballs.

The Food Value of Fungl.-Many people thoughtful for the welfare of those with limited opportunities for varying their bill of fare have hoped to solve the problem by introducing into more general use the varied and abundant fungi which grow everywhere throughout our country. In order to accomplish this object, bulletins have been published by the several agricultural departments, and have been distributed freely to those wishing to have them. The result has been that a wide-spread interest has been created in this branch of botany, and fungi have become a common dish on tables where they were never before seen.

As accessories, for relish or variety, edible fungi are undoubtedly valuable; but that they can never take the place of meat, as many fondly hoped, nor rank very high as an essential food, has been shown by the experiments of Mr. L. B. Mendel in the Sheffield Laboratory of Physiological Chemistry, Yale University. Mr. Mendel has demonstrated by chemical analysis and by experiments in artificial digestion that the proportion of proteid matter-the material which meat supplies-is smaller than it was formerly supposed to be, and also that a large proportion of that present is not acted upon by the digestive juices. Since, also, the proportion of water to solid matter is very great, being from seventy to ninety per cent. in the most desirable edible species, it would be necessary that a man should eat a great many pounds of even the richest fungi in order to obtain the daily requisite of proteid matter necessary to maintain a healthy constitution.

The specimens marked edible in this book have been repeat- 
edly tried by many people, and without ill effects. Some marked edible are harmless, but poor, while others are extremely delicious and appetizing.

A few directions for preparing different species for cooking are given below, that those who wish to experiment may have the benefit of the experience of others. Receipts for cooking the common mushroom, Agaricus campestris, may be found in all complete cook-books, and these receipts as they are given or modified may be used for other kinds also, provided that the directions for the preparation of the different species are followed.

To Keep Mushroons Temporarily.-Cleanse, remove the parts to be rejected, rinse in cold water the parts to be used, dry with a cloth, then put in boiling water and keep boiling for five or ten minutes. Drain, and wipe dry.

To Prepare the Edible Agarics for Cooking.-Cleanse, cut off the stems and throw them away. Rinse the caps in cold water, drain, and leave in cold water acidulated with lemon or vinegar until just before using.

To TOAst Agarics.--Dry with a cloth, dust with flour, put a little butter, pepper, and salt on the gills. Lay the caps, gills upward, on a wire-net toaster, over a moderate fire, and cook from five to ten minutes.

To BAKE Agarics. - Dry with a cloth. Line a porcelain piedish with toast, spread the peeled caps on the toast, sprinkle with pepper and salt, and pour over them a few spoonfuls of thick cream. Cover with a plate, and place in a moderate oven for fifteen minutes. Serve hot. Or,

Line the dish with toast dipped in hot water and buttered. Spread the caps on the toast, with half a teaspoonful of butter on each one. Cover, and cook in a warm oven for ten minutes.

To Broll Agarics-Broil lightly on both sides over a bright fire. Arrange on buttered toast, sprinkle with pepper and salt. Put bits of butter or bits of toasted bacon on each, and set in the oven a moment. Serve hot.

Mushrooms Stewel-C - Cips, peeled, one quart; butter, two tablespoonfuls; salt, one teaspoonful; pepper, one-third of a teaspoonful; water or stock, one-half cupful. Boil gently in a covered stewpan for five minutes. Or,

Caps, peeled and cut in pieces, one pint; butter, one table- 
spoonful; salt, one-half teaspoonful; pepper, one pinch. Simmer in a stewpan for ten minutes.

To Prepare Russulas-Reject the stems and gills, but not the peel. Cleanse the caps, rinse in cold water, then put for a moment in boiling water, and dry with a cloth. Cook by the receipts given for agarics.

To Prepare Fungi with Milky Juice-Remove the stems, cleanse, rinse, and scald. Steep for six hours in a liquid prepared by mixing one wineglass of strong vinegar, one tablespoonful of salt, and one pint of water. Boil for ten minutes in salt and water. Cook by the receipts given for agarics.

LACTARIUS DELICIOSUS-Known by its greyish-orange cap marked with brighter zones, and by its orange milk. Also

LACTARIUS VOLEMUS-Known by its reddish-brown cap, two to five inches across, with stems of the same colour, and white milk. May be prepared by simply removing the bases of the stems and then rinsing in water.

To Prepare Amanitas-Reject the stems and peel, and cook but a short time.

To Prepare Chanterelles-Cut off the base of the stems, rinse in cold water, soak in warm milk for six hours. Stew a long time with plenty of butter or stock. Use with meat hashes and stews, or in omelet.

To Fry Chanterelles-Wash, slice, put in melted butter, and stir for ten minutes, simply keeping them warm. Add more butter, pepper, salt, crumbs of bread, and minced parsley, and fry over a hot fire.

To Prepare Coprini-ink Caps-Use only young specimens. Remove the base of the stems, wipe with a damp cloth. Throw for an instant into boiling water. Fry in boiling butter or lard. Remove from the pan as soon as they break or sink. Serve on toast.

To Prepare Bolet]-Remove the tubes with a spoon. Reject the stems.

To Prepare Hydnum repandum-Remove the bases of the stems, and scrape off the spines. They require little cooking.

To Prepare MORels-Cleanse; rinse by shaking them in several waters, or run the cold water from the faucet over them until the pits are thoroughly cleansed. They require to be cooked for a long time. 
To Prepare Beefsteak Fungus-Gather when of a lightred colour. Remove the hard base, cleanse in cold water.

For salad-Cut in thin slices and serve with dressed lettuce.

Minced-Mince fine, put in a stewpan with butter, three ounces to the pound. Season with salt, pepper, minced parsley, and onion juice. Stew gently for twenty minutes. Bind with egg-yolk beaten in cream, and serve with toast. This mince may be used with veal or chicken hash.

To Prepare Gyromitras. - Cleanse, cut in slices, boil in water fifteen minutes, then wash by shaking in two successive waters boiling hot. Dry on cloths, and cook as directed for morels.

To Prepare Woody Pore-bearing Fungl-Polyporf.-Take the soft parts of young specimens. Put in boiling water for a few moments, rinse in cold water, and dry on cloths. Spread with butter, lay in a stewpan, and cover; then keep them for ten minutes just warm enough to melt the butter. Strain, broil for fifteen minutes, or stew hall an hour or more with gravy.

To Prepare Clavarias and Branched Hydnums. - Cleanse, throw into scalding water for a moment, and then put into cold water made acid with lemon or vinegar until they are to be cooked. Divide the large ones, and tie the small ones into bundles. Place in a stewpan with bits of butter laid on them. Cover the pan, and expose to heat enough to melt the butter. Leave for ten minutes, and drain.

To Cook Clavarias. - Put into a hot stewpan with bits of butter; season with salt, pepper, and lemon juice. Cover closely, and stew for half an hour. Thicken with cream and flour, season to taste, and cook until tender.

Clavarias may also be cooked as directed for agarics.

To Prepare PuffBalls.-Cleanse, peel, trim off the base. Cut in two pieces, and reject all those which are not pure white within.

To Cook Puffballs. - Fry in lard five or six minutes, with bacon, parsley, onion juice, salt, and pepper; or cook as directed for agarics.

To Cook the Giant Puffball. - Cut in slices half an inch thick, dip in the beaten yolk of egg, pepper, and salt. Fry in boiling fat for five or six minutes.

Puffball Salad. - Cut in strips, and serve with green salad dressed with mustard, oil, and vinegar. 



\section{AUTHORITIES CONSULTED}

ATKINSON. Studies and Illustrations of Mushrooms, 1, 11. Bull. Cornell Univ. Expt. Station, 138: 337-366, f. 87-112. 1897. 168:491-516, f. 83-97. 1899.

BURNAP. Notes on the Genus Calostoma. Bot. Gaz., 23: 180-192, Pl. 19. I 897 .

BURT. A List of the Vermont Helvellaceæ, with Descriptive Notes. Rhodora, 1: $59-67, \mathrm{Pl} .4$. 1899.

- On Collecting and Preparing Fleshy Fungi for the Herbarium. Bot. Gaz., $25: 172-186, P 1.14 .1898$.

— The Phalloideæ of the United States, 1-III. Bot. Gaz., 22 : 273-292, Pl. II, I2; 379-391. 1896. 24: 73-92. 1897.

COOKE. Edible and Poisonous Mushrooms. 8vo, 18 plates. London, 1894 .

- Illustrations of British Fungi. 8 vols., $P 1.1-1198$. London, $1881-1891$. Mycographia. Pl. $1-113$. London, 1879. [Pezizales.]

Mycographia. 1-10, 87-104, 179-206, 215-220; Pl. 1-4, 41-46, 81-96, 101, 102. 1879. [Helvellales.]

COVILLE. Observations on Recent Cases of Mushroom Poisoning in the District of Columbia. U. S. Dep. Agr., 1897.

FALCONER. Mushrooms: How to Grow Them. U. S. Dep. Agr., 1896.

FARLOW. Edible and Poisonous Mushrooms. U. S. Dep. Agr., I 898.

FRIES. Icones selectæ Hymenomycetum, Holmix. 2 vols. 1867-1884.

HAY. Text-book of British Fungi. Svo. London, 1887.

MASSEE. A Monograph of the Geoglosseæ. Annals of Bot., 225-306, Pl. 12, 13. 1897 .

19. 1897

A Monograph of the Genus Calostoma, Bot. Gaz., 23 : 18o-192, Pl.

A Monograph of the British Gastromycetes. Annals of Bot., Vol. IV, No. XIII. November, 1889 .

MENDEL. The Chemical Composition and Nutritive Value of some Edible American Fungi. Am Jour. of Physiology, 1: 22;-2;8. 1898. 


\section{Authorities Consulted}

MICHAEL. Führer für Pilzfreunde. 12mo, 55 plates. Zwickau, 1897.

MORGAN. North American Fungi. Jour. Cincinnati Soc. Nat. Hist., II: $141-149$, Pl. 3. 1889. [Phallales.]

- North American Fungi. Jour. Cincinnati Soc. Nat. Hist., 12 : 8-22, Pl. 1, 2. 1889. 163-172, Pl. 16. 1890. 13:5-21, Pl. I, 2. 1891. 14: 141-148. Pl. 5. 1892. [Lycoperdales.]

PECK. Reports of the State Botanist of New York, in the Regents' Reports of the State Museum of Natural History, 22-51.

_- Boleti of the United States. Bull. N. Y. State Mus., No. 8. 1888.

STEVENSON. British Fungi. 2 vols.

UNDERWOOD. Moulds, Mildews, and Mushrooms. New York, 1899. On the Distribution of the North American Helvellales. Minn. Bot. Studies, 1 : 483-500. 1896.

WEBSTER. Notes on Calostoma, Rhodora, 1: 30-33. 1899. 


\section{NOTE}

It is customary, when writing the name of a fungus for scientific purposes, to append the name of the author who first published the appellation. The author's name, for convenience, may be abbreviated. A list of such abbreviations as are used in this book is given below.

A. \& S. Albertini and Schweinitz.

BATSCH. Augustus Batsch ( I 76I-I 802), German botanist.

BERK. Rev. Miles Joseph Berkeley.

B. \& C. Berkeley and Curtis.

Bosc. Louis Bosc (1759-1828), one of the first collectors of fungi in the United States.

Bull. Pierre Bulliard, 1742-1793.

Burnap. Charles E. Burnap, an American student.

BuxB. Johann Christian Buxbaum, 1693-1730.

D. C. Augustin Pyrame de Candolle (1778-1841), a prominent Swiss botanist.

Desv. Nicaise Augustin Desvaux, French botanist, 17841856.

Eluis. J. B. Ellis. Mr. Ellis is a mycologist in the United States. The Ellis collection of fungi contains the largest number of types of any collection of American fungi in existence. It is deposited in the museum of the New York Botanical Garden.

Fr. Elias Magnus Fries (1794-1878), a Swedish botanist, who laid the foundations for the study of the Basidiomycetes.

Holmsk. Theodor Holmskiold (1732-1794), a Danish botanist.

Huds. William Hudson (1730-1793), an English botanist.

LasCH. Wilhelm Lasch $(1786-1863)$, a German botanist.

Lk. Heinrich Friedrich Link $(1767-1851)$, a German botanist.

L. or Lins. Carl von Linnæus (1707-1778), a Swedish bot:mist. who revised the principles of classification and introduced what is known as the binomial nomenclature. According to his method, the name of a plant is reduced to two words: the first, or 
generic, name is a substantive or a word used as a substantive; while the second, or specific, name is an adjective. Lactarius is the generic name of those fungi dripping milk, and deliciosus (delicious) the specific name for one edible species.

Mass. George Massee, an English botanist.

Morg. A. P. Morgan, an American botanist.

PK. Charles H. Peck (1833- ), the State botanist of New York.

Pers. Christian Hendrik Persoon (1755-1837), a German botanist.

Roze. Ernest Roze, a French botanist.

Schw. Lewis David de Schweinitz (1780-1834), an American botanist ; one of the first to make mycology a serious study.

Scop. Giovanni Antonio Scopoli (1723-1788), an Italian botanist.

Sch«FF. Jacobi Christiani Schæffer (1718-1790), a German botanist.

Sacc. P. A. Saccardo (1845- ), an Italian botanist. Saccardo is the compiler of Sylloge Fungorum, a work in Latin, containing descriptions of over forty thousand species. It is a most valuable work, as it has made accessible to workers throughout the world the greater part of the technical descriptive literature upon the subject of fungi.

VaHL. Martin Vahl (1749-1804), a Norwegian botanist.

The diacritical marks used in the pronunciation of the Latin names indicate the sounds of the same letters in the following list :

$\begin{array}{lll}\breve{a} \text { as in fat } \\ \bar{a} \text { " } & \text { fate } \\ \check{e} & \text { " } & \text { met } \\ \bar{e} & \text { " } & \text { meet } \\ \text { y } & \text { " } & \text { fin } \\ \bar{i} & \text { " } & \text { fine } \\ \check{o} & \text { " } & \text { not } \\ \text { o } & \text { note }\end{array}$

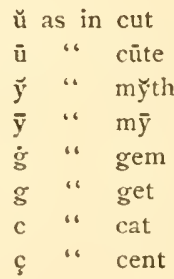




\section{INDEX AND GLOSSARY}

Adnate, 35; united by Arachnoid, 38; web-like. Boleti, care of spores. growth; said of gills Armillaria, 34. when they are grown to the stem.

- mellea, 6I.

Agaricaceæ, 30, 32, 40, $46,73$.

Agaricales, I4, 30 .

Agaricus, 39, 73.

- abruptus, 77.

- arvensis, 75.

- campestris, I2, 75, 76 .

- cretaceus, 64 .

- hemor rhoidarius, 75 .

- how to grow, 73 .

- maritimus, 75 .

- placomyces, 75 .

- Rodmani, 75, 76 .

- subrufescens, 75 .

- sylvaticus, 75 .

Algæ, 9 .

Algal-like fungi, 9, I 7 .

Amanita, 34, 46.

- Cæsarea, 50, 52.

- Frostiana, 52.

- muscaria, 52.

- phalloides, 48.

- to prepare, for cooking, I 54 .

- verna, 65.

- young plant, 47 .

Amanitopsis, $34,53,88$.

- parcivolvatá, 55 .

- vaginata, 54.

- - var. alva, 54.

- - var. fulva, 54 .

- - var. livida, 5.

Anthurus, 26.

- borealis, 121 .

Antidote, 48; anything that will counteract the effects of poison.

II 130. 97, I 6 . 7.

Black knot, 9.

Boleti, I4. \begin{tabular}{c|c} 
- - var. bulbosa, 62. & - of the United States, \\
- - var, exannulata, 62. & I04.
\end{tabular}

- var. flava, 62. - which change colour, 104.

Boletinus, 45, 102, 103.

$\begin{array}{ll}\text { - - var. radicata, 62. } & \text { - pictus, } 103 . \\ \text { Asci, IS, I9: the sacs in } & \text { - painted, } 103 .\end{array}$

Asci, I8, I9; the sacs in - painted, I03. which the spores of Boletus, 4., IO4. the cup fungi are de- - Americanus, Iog. veloped. - bicolor, I05.

Ascoma, 19, 20, 21; the - calopus, I06. disk-like body bear- - castaneus, IOS. ing the spore-sacs - chrysenteron, Io6. of the cup fungi and - cyanescens, I05. their allies. - edulis, Iog.

Ascomata, 20, 21; plural - eximius, IoS. of ascoma. $\quad-$ felleus, I07.

Ascomycetes, 17, IS, I 35. - glabellus, I04.

Ascus, I 7; singular of asci. - mutabilis, I05.

Astræus hygrometricus, - pallidus, I05.

- Peckii, Io6.

- purpureus, Io7.

Basidia, I6, I 7 ; enlarged cells bearing spores.

Basidiomycetes, 14, 17 ,

Bean seed to show embryo,

Bear's head, 2, 96 .

Beefsteak fungus, 103.

- for salad, 155.

- minced, I55.

- to prepare, 155.

lird's-nest, 24, 133.

Bitter Boletus, $10 \%$.

Boletacex, 3I, 44, IO2.
— radicans, I06.

- Satanus, 107.

- scaber, ros.

- speciosus, 105.

- subtomentosus, IO9.

- versipellis, Ios.

Boston Mycologrical Club. I45.

Bovista, 128 .

- plumbea, 125.

- section of, I $2 S$.

Bovistella, 29, I 24, I 29.

- Oluiensis, Iæ9.

Brackets, 2, 4 .

Brain-shaped Calvatia, I2G

Branches, 7 . 
Brick top. (Pl. opposite / Capitila. (Pl. opposite p. / Clavaria, golden, roo. p. 81.) 136.)

- pale yellow, 99 .

Brick-red mushroom, 8o.

Button, II, I 2 ; the name given to a young mushroom.

Cæsarea, 50.

Cæsar's mushroom, 5 I.

Cæspitose, 145 ; growing in clumps, many plants from one root.

Calostoma, 29, I23, I24, I 31 .

- cinnabarinum, $\mathrm{r} 32$.

- lutescens, 132.

- Ravenelii, I32.

Calvatia, 28, 124, 126.

- craniformis, I 26.

- cyathiformis, I28.

- fragile coat, 126 .

- maxima, I27.

- section of, 126.

Cambium, I 37 ; the delicate young cells between the wood and bark. The inner become new wood; the outer, new bark.

Campestris, 76 .

Caninus, I20.

Cantharellus, 36, 53.

- cibarius, I48.

- floccosus, 53.

Cap, defined, I2.

- membranous, 35.

- ragged edge, 13.

- scaly, 3+.

- smooth, 34.

- striate, 50.

- umbonate, 63 .

Capillitium, 25, I26: simple or branched threads mixed with spores.

- elastic, I26.

Capitate, 21 ; having a distinct head.

Caput-ursi, 96.

Carbon, 4; an elementary substance found in plant and animal tissue.

Cartilaginous, $36, \quad \mathrm{r} 46$; similar to the elastic tissue found at the ends of fresh bones.

Caterpillar, fungus growing on, 136 .

Cautions, I 5 I.

Cell, II ; a living vegetable unit.

- spore, II.

- club-like, I3, I4.

Cervinus, 87.

Chalk agaric, 64 .

Chanterelle hygrophorus, 59.

- to fry, I 54 .

- to prepare, 154.

Chemical analysis, 152.

Chestnut Boletus, IOS.

Chitonia, 83.

Chlorophyll, 6, I4t; the green coloring matter of plants.

Christmas greens, 5, 7.

Chrysenteron, I06.

Cibus Deorum, $5 \mathrm{I}$.

Cinnabarinum, 132 .

Circinatus, II 3.

Class, $7,15,17$.

Classification, 5, 7 .

Clathracex, 26, I I 7, I2r.

Clathrus, 26, I2I.

- cancellatus, I2I.

- columnatus, I2I.

Clavaria, 3, I4, 99.

- aurea, roo.

- botrytes, I00.

- cristata, Ioo.

- fellea, IoI.

- flava, 99.

- formosa, IOI.
- pistil, IOI.

- pistillaris, Ior.

- red-tipped, Ioo.

- to cook, 155 .

- to prepare, 155 .

Clavariacex, 30, 98, 99.

Clavate, $2 \mathrm{I}$; club-shaped.

Clitocybe, 35, 68, 70 .

- laccata, 70.

- care of spores, I48.

Clitocybe virens, $7 \mathrm{I}$.

- var. amythystina, 7I.

- var. pallidifolia, 7 I.

- var. striatula, 7 I.

Clitopilus, 37, 88.

Collector, notes of, 145 .

- outfit of, 147 .

Collybia, 35, 66.

- care of specimens, I5O.

- care of spores, 148 .

- familia, 67.

- radicata, 66 .

- radicata, care of spores, I 48.

- velutipes, 66 .

Columella, I25.

Common mushroom, 76 .

Context, 42 ; the tissue immediately in contact with a specified part.

Coprinarii. See Coprini.

Coprini,careof spores, I48,

- to prepare, $\mathrm{r}_{54}$.

Coprinus, 40, 89 .

- atramentarius, $9 \mathrm{r}$.

- comatus, iii, $v$, viii, 90

- micaceus, $9 \mathbf{I}$.

Coral fungi, 98 .

Coral Hydnum, 97.

Cordyceps, I36.

Corollas, 6.

Cortinarii, care of spores 148.

Cortinarius, 38,85 .

- alboviolaceus, 87 . 


\section{Index and Glossary}

Cortinarius violaceus, 87 . Count de Vecchi, 49.

Craniformis, I26.

Craterellus cantharellus, 73.

Crested Clavaria, I00.

Crucibulum, I33.

Cup fungi, I9, 137.

Cup-shaped puffball, I2S.

Cyathiformis, 128.

Cyathus, I33.

Czar Alexis, 49.

Dædalea, 43.

Death Cup, 48 .

Deconica, 39, 82 .

Decurrent, 35 ; growing down the stem; said of gills.

Deliquescent, 26 ; dissolving or melting away.

Destroying Angels, 2. See Death Cup.

Dictyophorus, 27.

Dissemination, of seeds, 6 ; the act of scattering.

- of spores, 4, I 18, 126, I3I, I33, 137.

Early Pholiota, 84.

Earth-stars, I23, I 29.

Earth-tongues, I 38 .

Eccilia, 87, 88.

Edible Boletus, Iog.

Elaphomyces, 136 .

Elias Fries, 97.

Elm Pleurotus, 58.

Emetic Russula. 68.

Entoloma, 37, 88.

Fairy clubs, 9.

Fairy-ring mushroom, 66 .

Fairy rings, 3 .

Families, 7, 16 .

Fat Pholiota, 83 .

Favolus, I1 5 .

- areolarius, I I 5 .
Fawn-coloured Pluteus, 87. | Fungi with teeth, 94Fern with spore capsules, $\mathrm{S}$. Fertile gleba, 125 .

97.

Fungus plant, 9 .

Fibrillose, I 46 ; furnished Fusiform, 40 ; cylindrical, with fibres.

Fistulina, 47 , I02.

- cavipes, I03.

- decipiens, I03.

- hepatica, I02.

- paluster, I03.

- porosus, I03.

Fistulose, I. 6 ; hollow through the whole length.

Flexuous, I4 6 ; bent alternately in opposite directions.

Flint-stone, I27; a stone formerly used for obtaining sparks.

Floccose, 45 ; clothed with locks of soft - notched, 58 . hair or wool. $\quad$ - structure, 13.

Flocculent, 52 ; woolly. - toothed, 56.

Flowerless plants, 5. - waxy, 6I.

Fly Amanita, 49. Clabrous, 50; not hairy.

Food of the gods, $5 \mathrm{I}$.

Frog-spittle, 6.

Fruiting portion, I2, I3.

Führer für Pilzfreunde, IOf.

Fungi, defined, 4 .

- for food, I, I 5 I.

- for the herbarium, I45.

- for the table, I5I.

- not grewsome, 2.

- habitat, 2. tapering gradually to each end.

Gasteromycetes, 2, 3, I 4 , 24.

Geaster, 28, I2ł, I29.

- hygrometricus, I 30 .

Genera, 7, 16.

Geoglossaceæ, 21, I38.

Geoglossum, I39.

— glabrum, I 39.

- hirsutum, I39.

Giant puffball, 127.

Gills, I2.

Gleba, 26, II7; the spore mass of the pouch fungi.

Glistening Coprinus, 9I.

Globose, 40; having or approaching a spherical form.

Golden Clavaria, Ioo.

Golden-flesh lioletus, Io6.

Golden Peziza, I38.

Gomphidius, 4, 92.

- fixing spores of, r.t8.

Grandinia, 94.

Grass spikelet, 7.

Gray-gilled mushroom, 79.

Green Russula, on.

Greeks, I.

Guepinia, I I6.

Gyromitra, 20, 140

If 1 .

- with pores, $f 2,44,102$, 155.

- with spines, 23, +I, $9+47$.

- esculenta, I4I.

- to prepare, I55. 


\section{Index and Glossary}

Habitat, $\mathrm{r} 45$; the locality| IIygrophorus, var. flava, Lactarius, to cook, I54. where a plant naturally lives.

60

- var. Haviceps, 60.

- var. flavipes, 60.

- var. rosea, 60. cating preparation of the Indian hemp.

Hedgehog Hydnum, 97.

- mushroom, 94 .

Ilelvella, 20, r4o.

- elastica, 142.

- lacunosa, 143.

- - diagrammatic draw. ing, 143.

- - section of stem, $\mathrm{r} 43$.

Ilelvellacex, 20, r40.

I Ielvellales, $19,1_{3} 8$.

Hirneola auricula-Judx, 116.

Honey-coloured Armillaria, 6I.

Host, 22; the plant or animal which supports a parasite.

Hydnaceæ, 32, 0.

Hydnum, 14, 32, 41, 94, I 6 .

- albidum, 95.

- branched, to prepare, 155.

- caput-medusx, 97.

- caput-ursi, 96.

- coralloides, 97.

- echinaceus, 97.

- imbricatum, 96 .

— repandum, 95.

- rufescens, 95.

Hydrogen gas, 4 ; one of the elements found in plant and animal tissue.

Hygrophanous, 145 ; opaque when dry, and transparent when moist.

Hygrophorus, 35, 59 .

- cantharellus, 59 .

- eburneus, 6 r.

- miniatus, 60 .

- incertum, 8o, 8r.
IIymenogastrales, I33.

Hymenomycetes, 2, I4.

Iypha, II ; a thread-like strand of the vegetative part of a fungus.

Hypholoma, 39, 78 .

— capnoides, 79.

- elæodes, 80.

- epixanthus, 79.

- fasciculare, 80.

- perplexum, 78, 79 .

- sublateritium, 8 I.

Hypocreales, I8, 136.

Imperial mushroom, $5 \mathrm{r}$.

Incertum, 8o, 8I.

Indian pipe, 7.

Ingenious stamens, 6 .

Ink-caps, 89.

Inky Coprinus, $9 \mathrm{I}$.

Irpex, 94.

Ivory Hygrophorus, 6I.

Jew's Ear, I 6 .

Judas's Ear, I I6.

Juice, milky, 32.

- watery, 32.

Juvenal, I ; a Roman poet, first century A.D.

Kaiserling, $5 \mathrm{x}$.

Key, 15-45.

Lachnocladium, 99.

Lactarius, 32, 92.

- care of spores, 148 .

- channeled, 33.

- crisped, 33.

- deliciosus, 154.

- entire, I.

- ligniotus, 93.

- piperatus, 92.
- to prepare, 152.

- volemus, $x 54$.

Lamellæ, 12.

- acute 35 ; the edges thin, not blunt.

- adnate, 35 ; grown to the stem.

- brittle, 35 .

- decurrent, 35 ; growing down the stem.

- entire, 47.

- free from the stem, 34 .

- obtuse, 36.

- shallow folds, 36 .

- simple, 33.

- sinuate, 35 .

- splitting deeply, 33 .

- toothed, 32.

- villous, 33; with soft hairs.

- waxy, 35 .

Larch canker, 137.

Large club, ror.

Latticed Clathrus, I 21.

leaf-green, $4,6, \mathrm{r}_{5}, \mathrm{r}_{44}$.

Lentinus, 32 .

- lepideus, 56.

Lenzites, 43.

- betulina, 113 .

- separia, II4.

Lepiota, 34,63 .

- Friesii, 65 .

- granulosa, care of spores, I49.

- naucinoides, 64.

- procera, 63.

- - care of spores, 148 .

Leptonia, 88.

Light from dry rot, 2.

Liverworts, 5, 7 .

Lycogala epidendron, I44.

Lycoperdales, 25, 28, 123.

Lycoperdon, 29, 124.

- cyathiforme, 128.

- giganteum, 127.

- maxima, 127.

- pyriforme, 125. 


\section{Index and Glossary}

Lycoperdon, section of, Mushrooms, to keep, I5. 124.

- subincarnatum, I25.

Lycopodiums, 7 . - to preparc, I53.

Mutinus, 27.

- bambusinus, r2o.

- caninus, 120.

Majoon, 49; an intoxicat- embryo plant, 120. ing confection of - young plant, I 20. India.

Maned agaric (see Comatus), ii, v, viii, go.

Marasmius, 33,65 .

- care of spores, 149 .

- oreades, 66.

Marchantia polymorpha, 7 .

Masked Tricholoma, 72.

Medusa's head, 97.

Mendel, 152.

Membrane fungi, $14,22$.

Merulius, I Io.

- lacrymans, iro.

Mitrula, 2 I.

- vitellina, var. irregularis, I 40.

Morels, I40, I 54.

- to prepare, $\mathrm{I}_{54}$.

Morchella, 2I, I40, I4I, 142.

- angusticeps, I 42 .

- bispora, 142.

- deliciosa, 142.

- esculenta, I $4 \mathrm{I}, \mathrm{I}_{42}$.

- section of, I4I.

- semilibera, I42.

Mould, 2.

- on bread, 9 .

- on food, 2.

- on dead fly, 9.

Mould-like fungi, 15,77 .

Mounting, I49.

Mount Marcy, 68.

Mucronella, 94.

Muscaria, 49.

Muscarine, 50; a poison found in $A$. muscaria.

Mushrooms, baked, 153.

- broiled, I53.

- stewed, 153.

- toasted, I53.

- luminosity of, 63 .

Mycelium, I I, I Io, 136.

- food provider, 13.

Mycena, 35, 55 .

- hæmatopoda, 55 .

Myxomycetes, I 44.

Name, not a vital thing, 150.

- the search for, I 50.

Nidularia, 133.

Nidulariales, 24, I33.

Nolanea, 88.

Odontium, 94.

Offensive fungi, I 17.

Omphalia, 35, 68 .

- umbellifera, 68.

Orange Amanita, 50.

Orange-cap Boletus, 108.

Orders, 7, 16.

Oreades, 3 . mentary substances plant tissues.

Oyster mushroom, 57.

Painted Boletinus, In3.

Panxolus, 92.

Panus, $33,67$.

Paraphyses, 135 : jointed tain fungri. food from living plants or animals.

Parasite, Cordyceps, on Elaphomyces, 136.

Parasol mushroom, 63 .

Paxillus, care of spores, 148.

Mycelial threads, I I 7, I23.

Oxygen, 4 ; one of the elewhich, chemically united with carbon and hydrogen, forms thread-like bodies found accompanyiug the spore-sacs of cer-

Parasite, 22; that which lives by aking its Pilosice $39,82$.
Peach cure, 9.

Pear-shaped puffball, 125.

Peridium, 14, 23, 24, 25, 123; the thickened covering to a puffball.

Perithecium, 55; a rounded, oval, pear-shaped, or beaked body in which the spore-sacs are developed.

Perplexing Hypholoma, 78,79 .

Perplexum, 78 .

Peziza, 22, 137.

- aruginosa, 137.

- aurantia, 138.

- odorata, 137.

- Willkommii, 137.

Pezizales, 19, 20, 137.

Phallacex, 27, I I 7 .

Phallales, 24, 117, 121.

Phallin, $4^{8}$; a deadly poison found in certain fungi.

Phalloides, Amanita, 45.

Phallus, 27.

- impudicus, I17.

- section of young impudicus, II).

Phlebia, 94.

Pholiota, 35 .

- adiposa, 83 .

- limonella, 83 .

- pracox, $s_{4}$.

Phycomycetes, 9, I7.

l'hylix, 7 .

Physalacria, 1$)^{4}$.

Pileus, 146 ; the cap of a inushroour.

Pilosace, $39,82$. 


\section{Index and Glossary}

Pinkish puffball, I25.

Pistachio nuts, 78 .

Pistil of St. Johnswort, 6.

- of violet, 6 .

Pistil Clavaria, IOI.

Pistillaria, 98.

Pleurotus, 32.

- ostreatus, 57.

- sapidus, 58.

- ulmarius, 58.

Pliny, 135 .

Pluteus, 37 .

- cervinus, 87 .

Poison Amanita, 48.

Poisoning, cases of, 49 .

- of herbarium sheets, I5O.

- recipes for, 150 .

Poisonous, 48, 49, I5I.

Pollen, 4, 6 .

Polypodium vulgare, 6 .

Polyporacere, 31, 42, I02, I09.

Polypori, I Io.

- to prepare, I55.

Polyporus, 42.

- arcularius, II2.

- circinatus, II3.

- conchatus, III.

- fomentarius, IIo.

- megaloma, i io.

- perennis, III.

- pergamenus, III.

- squamosus, II2.

- sulphureus, III.

- velutinus, III.

Pores, I4; the openings of the spore-bearing tubes.

- easily separating from the adjoining tissue, $44,102$.

- in radiating rows, I02.

- in the form of tubes whose mouths are separated, 44, 102.

- long-hexagonal, 43.
Pores, permanently united to adjoining tissue, $42,102$.

- separating with difficulty, 45 .

- to prepare woody, I55.

Pouch fungi, 14, 23, 123.

Pruinose, 146 ; as if frosted with a bloom or powder.

Psathyra, 39, 82.

Psathyrella, 40, 92.

Psilocybe, 39, 82.

Protoplasm, I44; the viscid, contractile, semifluid substance of an animal or vegetable cell.

Protozoa, I44; unicellular microscopic animals.

Pterula, 99.

Puffballs, 3, 4, 123.

- salad, 155.

- to cook, 155.

Purple Boletus, I07.

Pycnodon, 94.

Radulum, 94.

Resupinate, $3 \mathrm{I}$.

Ring, I2.

- movable, 63 .

Rodman's mushroom, 76 .

Romans, I.

Rough-dried plants, I 49 .

Russia, 49.

Russula, 3, 35 .

- care of spores, 148.

- emetica, 68.

- heterophylla, 70.

- to prepare for cooking, 154 .

- virescens, 69.

Salmon fungus, 9 .

Saprophytes, I23.

Scaly Lentinus, 56 .

Schizophyllum, 33, 67.

Scleroderma, I 33 .
Scleroderma vulgare, 134 .

Sclerodermatales, 25, I33.

Seed-boxes, 5,8 .

Sensitive plant, 89 .

Shaggy-mane, ii, v, viii, 90.

Shelley, I, 2, 89 .

Silver fir, 6 .

Simblum, 26.

- rubescens, 122.

Sinuate, 35 ; said of gills which have a notch or recess near the stem.

Slime fungi, I44.

Smallest Earth-star; I30.

Smith, Rev. Gerard, 3.

Smokeballs, I23.

Smooth Lepiota, 64.

Smuts, 2, I4, 22.

Sparassis crispa, 99.

Spathularia, 21, I 38 .

- velutipes, 138 .

Species, 7, 16.

Specimens, 7.

- care of, 147.

Spencer, 2, 5.

Sphæriales, 136.

Sphre robolus, I 33.

Spines, I4, 4I.

Spore-dust to stanch blood, I 27.

Spore print, 4.

- receptacle, Io.

Spore-sac fungi, 9, 17, I8, I 35 .

Spores, II ; single cells which serve the same purpose for fungi as seeds do for flowering plants.

- black, 32, 46, 89-92.

- brown, 38, 73-83.

- colour, 4 .

- collecting of, 147 .

- dark brown, 32, 73-83.

- dissemination of, 4 , II 8, I 26, I 31 , I 33, I 37 .

- elliptical, 72 .

- fusiform, 40 . 


\section{Index and Glossary}

Spores, how formed, I 2 . - in a definite rind, I4, $23,123$.

- on spicules, 9.

- pink, 36, 46, 87,88.

- purplish-brown, 32 .

- rough, 69 .

- rosy, $32,87,88$.

- rusty brown, 32, 46 , $83-87$.

- salmon, 32, 87, 88 .

- violet, 32,58 .

- white, 32, 46-73.

- yellowish-brown, 32, $83-87$.

Spreading Hydnum, I95.

State botanist, I 50.

Stem, I2, 13.

- cartilaginous, 35 .

- central, 60 .

- characters of, 46 .

- cup at base, $47,49,50$, 54,88 .

- eccentric, 56 .

- fleshy, 5 .

- hollow, 50.

- lateral, 58.

- mealy, 46 .

- rusty, 46 .

- smooth, 46 .

- solid, 56 .

- swollen base, 48 .

- wanting, $\mathrm{I} 3 \mathrm{3}$.

Sterigmata, 9, I $7 ;$ the slender stalks or spicules upon which the spores of the Basidiomycetes are borne.

Sterile, 29 ; not containing spores.

- base, 125.

Stinkhorns, 24, 26, II 7, 123.
Stipe, I2 ; stem of fungus.

Striate, 35, 50 ; said of the cap when marked with radiating straight lines on the margin.

Strobilomyces, 102.

Stroma, I36 ; a compact mass of mycelium which unites the pear-shaped bodies in which spore-sacs are contained.

Stropharia, 39, 82.

Sulphury polyporus, III. Sistotrema, 94.

Tall Lepiota, 63.

Thelephoracex, 73 .

Tinder, 127 ; dry material which will ignite without explosion when in contact with a spark.

Toadstool, 2,8 .

Tox-albumins, $4^{S}$; poisonous proteids produced by bacteria.

Trama, 42; a middle tissue between two layers of spore-bearing tissue.

Trametes, 42, I IO, II 3 . - cinnabarina, I 13 .

- pini, II3.

- suaveolens, I I 3 .

Tremellines, 22.

Tremellodon, I 16 .

Tricholoma, 35 .

- care of spores, 148.

- personatum, care spores, 149 .
Tricholoma personatum, var. bulbosum, 72 .

Trogia, 33 .

Truffles, I 8 .

Tuberales, I $8,30, \mathbf{I} 35$.

Tufted yellow mushroom, 80 .

Tunbridge ware, 137 .

Typhula, $9^{8}$.

Umbilicate, 146 ; provided with a central depression.

Umbonate, 63 ; provided with a central prominence.

Uncertain IIypholoma, 8.

Variable Russula, 7o.

Veil, I2, II3; the membrane which covers the spore surface of a fungus in the young stage.

Velvety Spathularia, I33.

Verdette, 69 .

Vermilion Hygrophorus, 60.

Vernal Amanita, 65.

Vibrissea, I39.

- circinans, 140.

- truncorum, 139.

Volva, $34,46,52$.

- of mutinus, 120.

Volvaria, 36,88 .

Water-measuring Earth. star, I30.

White Iydnum, 95.

Wrapper, 47, 49, 50, 51, 54 .

Xylaria, 136.

f

Yeast plant, 9 . 



\section{INDEX OF PLATES}

Agaricus abruptus, 74, Chanterelle Hygropho- $\mid$ Fat Pholiota, 6r.

77 .

- campestris, 74, 75.

- Rodmani, 76 .

Amanita Cæsarea, 50.

- muscaria, 49.

- phalloides, 48 .

Amanitopsis parcivolvata, Frontispiece.

- strangulata, 53 .

- vaginata, 54.

Armillaria mellea, 6r .

Bear's head, 96.

Bird's-nest, 130.

Bitter Boletus, 107 .

Boletinus pictus, 103 .

Boletus chrysenteron, 60.

- felleus, var. obesus, 107.

- scaber, var. niveus, 108.

Bovistella Ohiensis, I 28 .

Brain puffball, I 26.

Brick top Hypholoma, $8 \mathrm{I}$.

Bristly panus, 145 .

Broad-gilled Collybia, 66.

Calostoma cinnabarina, 132.

- lutescens, I32.

- Ravenelii, ${ }^{32}$.

Calvatia craniformis, I 26.

- cyathiformis, 128.

Cantharellus floccosus, 136. rus, 60.

Clavaria aurea, 100.

- formosa, 101.

- ligula, 98 .

Clitocybe illudens, 70.

- laccata, 67 .

— virens, $7 \mathrm{I}$.

Collybia familia, 67 .

- maculata, 66.

- platyphylla, 66.

Cone-like Boletus, 102.

Coprinus atramentarius, 91 .

- var. silvestris, 89 .

Coral Hydnum, 97.

Cordyceps capitala (Parasitic on Elaphomyces), ${ }_{3} 6$.

Cortinarius alboviolacens, 65 .

- armillatus, 86.

- caninus, 85 .

Craterellus cantharellus, 73 .

Cup-shaped Calvatia, 128.

Cyathus vernicosus, 130.

Dædalea quercina, 114

Death cup, 48 .

Deceiving clitocybe, 70.

Delicious morel, 142 .

Dog cortinarius, 85 .

Early Pholiota, 84.

Elaphomyces, 136 .

Elfingia fomentaria, I10.

Emetic Russula, 68. 169
Fawn-coloured Plute. us, 87 .

Field mushroom, 75 .

Flesh-coloured puffball, 134 .

Floccose Chanterelle, 136.

Fly Amanita, 49.

$\mathrm{F}$ o m e s fomentarius, I I O.

Geaster hygrometricus, 130.

- minimus, rzo.

Golden Clavaria, 100.

- flesh Boletus, 60.

- Peziza, i 38 .

Grainy Lepiota, 63.

Green Russula, 69

$\mathrm{H}$ a rd-skinned puffball, 134 .

Helmet Mycena, 55 .

Helvella elastica, 140.

- lacunosa, 140.

Hirneola auricula. Judx, i16.

Honey-coloured Armillaria, 6r .

Hydnum caput-ursi, 96.

- coralloides, 97.

- repandum, ro 3.

Hygrophorus cantharellus, 60 .

- eburneus, 84 .

- miniatus, 60 .

Hypholoma incertum, So.

- perplexum, 78 .

- sublateritium, 8 I 
Inky Coprinus, $9 \mathrm{r}$. - wood variety, 89 . Ivory Hygrophorus, $\delta_{4}$.

Jelly-like Trcmellodon, 137 .

Jew's ear, I 6 .

Lactarius ligniotus, 93. - piperatus, 92.

Least Earth-star, I30.

Lentinus lepideus, 56.

- strigosus, 45.

Lenzites betulina, 1 I 3 .

Leotia lubrica, I 37 .

Lepiota Friesii, 65.

- granosa, 63 .

- nancinoides, 64 .

- procera, 64.

Little-tongue Clataria, 98.

Lycogola epidendron, I 36.

Lycoperdon pyriforme, I 25,134 .

- subincarnatum, I34.

Masked Tricholoma, 72.

Mitrula vitellina, var. irregularis, I 40.

Morchella deliciosa, I 42 .

Mutinus caninus, I 36 .

Mycena galericulata, 55.

- hæmatopoda, 93.
Orange amanita, 50.

Oyster mushroom, $5^{8 .}$ Painted Boletinus, 103 .

Panus strigosus, 145 .

Parasol mushroom, 64.

Pear-shaped puffball, I 25.

Peppery Lactarius, 92.

Perplexing Hypholo$\mathrm{ma}, 78$.

Peziza aurantia, I 38 .

- odorata, ${ }_{3} 8$.

Phallus impudicus, I 9 .

Pholiota adiposa, 6I.

- aggericula, 73 .

- præcox, 84 .

Pleurotus ostreatus, 58 .

Pluteus cervinus, 87 .

Poison Amanita, 48.

Polyporus arcularius, 142 .

- circinatus, I I 2 .

- fomentarius, I I o.

- versicolor, I 12.

Rodman's mushroom, 76.

Russula emetica, 68 .

- virescens, 69.

Scabrous-stemmed Boletus, io8.

Scaly Lentinus, 56 .

Scleroderma vulgare, I 34 .
Sheathed Amanitopsis, 54 .

Slippery Leotia, I 37.

Smooth Lepiota, 64.

Spathularia velutipes, I 32 .

Spotted Collybia, 66.

Spreading Hydnum, IO3.

Strangled Amanitopsis, 53 .

Strobilomyces strobilaceus, 102.

Tall Lepiota, 64 .

Tremellodon gelatinosum, I37.

Tricholoma personatum, var. bulbosum, 72 .

Uncertain Hypholoma, 80.

Vermilion Hygrophorus, 60.

Wrater-measuring Earth-star, 130.

Tylaria, I 6 .

Young pear-shaped puffball, I34.

Zoned Cortinarius, 86. 

Date Due

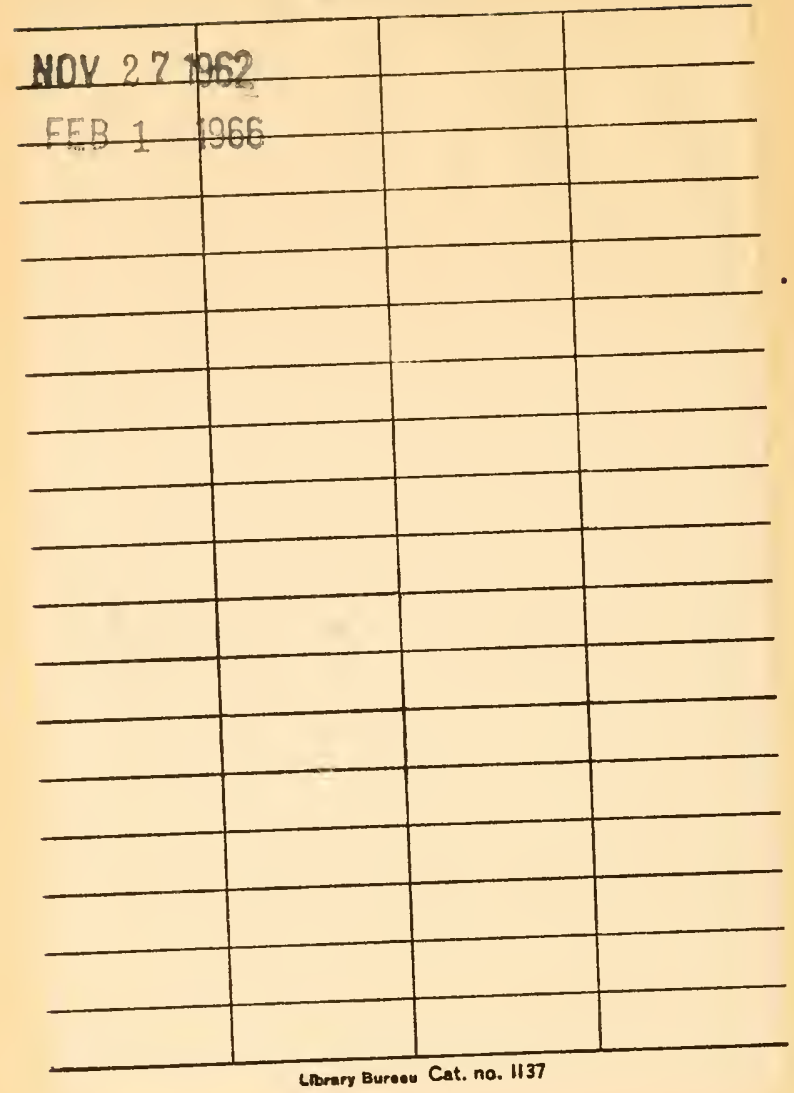


Marshall

\section{WTHDAAWN \\ FROM HSNY LIBRARY}

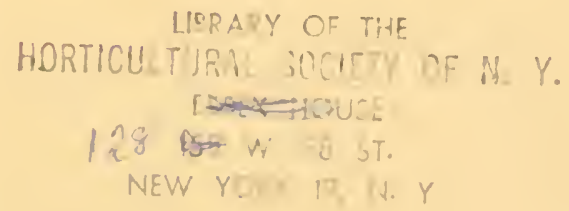


